UNIVERSIDADE DE SÃO PAULO

FACULDADE DE EDUCAÇÃO

PROGRAMA DE PÓS-GRADUAÇÃO EM EDUCAÇÃO

A REESTRUTURAÇÃO DA EDUCAÇÃO SUPERIOR NO BRASIL E O PROCESSO DE METAMORFOSE DAS UNIVERSIDADES FEDERAIS:

o caso da Universidade Federal de Goiás (UFG)

JOÃO FERREIRA DE OLIVEIRA

ORIENTADOR

Prof. Dr. AFRÂNIO MENDES CATANI 


\author{
UNIVERSIDADE DE SÃO PAULO \\ FACULDADE DE EDUCAÇÃO \\ PROGRAMA DE PÓS-GRADUAÇÃO EM EDUCAÇÃO
}

\title{
A REESTRUTURAÇÃO DA EDUCAÇÃO SUPERIOR NO BRASIL E O PROCESSO DE METAMORFOSE DAS UNIVERSIDADES FEDERAIS:
}

o caso da Universidade Federal de Goiás (UFG)

JOÃO FERREIRA DE OLIVEIRA

Tese apresentada como exigência parcial para obtenção do Título de Doutor em Educação à Comissão Julgadora da Faculdade de Educação da Universidade de São Paulo (USP), sob a orientação do Prof. Dr. Afrânio Mendes Catani.

Sub-Área Temática: Cultura, Organização e Educação

\section{São Paulo} 2000 


\section{RESUMO}

Esta pesquisa objetiva desvelar o atual estado de mudança que configura o processo de metamorfose das universidades federais, ou melhor, as modificações que estão se processando e as novas feições assumidas, tomando como referência básica o caso da Universidade Federal de Goiás (UFG). Examina como se equaciona a questão da natureza, da identidade e do papel da UFG no quadro das atuais políticas de educação superior e das tensões e desafios contemporâneos. A investigação teve como ponto de partida a politica de diversificação e diferenciação que reconfigura o sistema de educação superior no Brasil, com base em um modelo que associa flexibilidade, competitividade e avaliação.

Desenvolveu-se uma investigação do cotidiano da gestão universitária e da produção do trabalho acadêmico da UFG, explicitando suas interfaces com o contexto mais amplo, particularmente com as atuais políticas de educação superior, resultando uma análise pormenorizada dos processos, movimentos e tendências nas áreas de gestão, financiamento, avaliação, currículo, pesquisa e pós-graduação.

A pesquisa evidencia a intensificação de um jogo concorrencial da diferenciação e da distinção institucional entre as universidades federais, ou melhor, da luta pela independência e pela ocupação de posições específicas e diferenciadas, o que pode contribuir para o desmonte do sistema federal, uma vez que esse processo vem rompendo, paulatinamente, elementos de convergência que parecem ter assegurado, historicamente, certo nivel de solidariedade nesse campo institucional. Ressaltam-se as diferenças essenciais entre as universidades que começam a ser exibidas, especialmente na forma de estruturação e de organização interna, na produção do trabalho docente, nos indicadores acadêmicos e na tomada de posição diante das politicas de educação superior e demandas do mercado.

As mudanças na UFG indicam amplo processo de modelação organizacional com o objetivo de torná-la mais ágil e eficiente como evidencia, por exemplo, a simplificação de sua estrutura acadêmica, a extinção progressiva dos departamentos, a tentativa de desburocratizar os processos administrativos e acadêmicos e a implantação de sistemas de controle e gerenciamento administrativos. Boa parte desse ajustamento faz-se por meio de uma adequação da gestão e do trabalho acadêmico aos parâmetros e aos ritmos da Gratificação de Estímulo à Docência (GED) e aos ditames das condições objetivas locais e regionais que se expressam por intermédio dos convênios e da prestação de serviços remunerados, além da expansão dos cursos de graduação e melhoria generalizada dos índices de produtividade. 


\begin{abstract}
This research aims to reveal the actual chanping situation that configures the Federal Universities metamorphose's process, actually, the chanpings that are being processed and new features being assumed, having as basic references the case of the Federal University of Goias (FUG). It is being examined the question of nature, the identification and the FUG role in the comtemporary challenges. The investigation had as start the political diversity and differentiation that configures, once again, the higher level educational system in Brazil, having basis on a model that assossiates flexibility, competition and valuation.

It was developed an investigation of the university administration and the academic work production at FUG, showing mainly its interfaces with a wider context, particularly with the actual political higher level education, resulting in a detailed process analyzes, movements and tendency in management area, finance, valuation, curricullum, research and postgraduation.

The research shows the intensity of a competition game the differentiation and of the institutional distinction amond Federal Universities, actually, the struggle for independency and for the occupation of specific and differentiated positions, what can contribute for the federal system collapse, once this process is showly collapsing, with converging elements that seem to be secured, historycaly, certain solidarity levels in this institutional field. The essential differences come up among universities that begin to be shown up, specially in the structural form and intern organization, in the teaching stuff production, in the academic indicatives and in the position takings before the political higher level education and market demands.

The FUG changings point to a wider process of organization modeling with the aim of turning it more agile and efficient with evidence, for example, its academic structure simplified, the departments progressively extinguished, the attempt to end the managment and academic processes of burocracy and the introduction of a control system and business managment. A large part of this adjustment comes by means of admnistration, academic work and Teaching Stuff Encouragment Gratification (TSEG) adaptions and the local and regional conditions aims that are expressed in agreements and paid labour, beyond graduation courses expansion and general productiveness and rates developments.
\end{abstract}


A meus pais

A Ivoneide,

minha companheira, de todos os momentos, com muito afeto

A Hadassa e João Marcos, nossos filhos

A Luiz Fernandes Dourado,

pela amizade, incentivo e convivência acadêmica

A meu orientador, Afrânio Mendes Catani, pela amizade, confiança e orientação acadêmica criteriosa que me levou a superar limites teóricos e práticos, tornando possível a realização deste trabalho 


\section{AGRADECIMENTOS}

Ao Professor Vitor Henrique Paro, pelas valiosas contribuições para a minha formação acadêmica e para o aprimoramento deste trabalho.

Aos Professores João dos Reis da Silva Jr. e Luiz Fernandes Dourado, pela importante colaboração no aperfeiçoamento desta tese.

Aos amigos Valter e João Henrique, pela convivência familiar na cidade de São Paulo e pelo apoio e encorajamento.

Aos amigos e colegas da pós-graduação: Theresa, Bianca, Rubens, Mônica, Daniela, Emília, Teise, Suemy, Marisa, Débora, Renata e Pedro pela rica convivência acadêmica e momentos inesquecíveis compartilhados.

Ao Prof. José Luiz Domingues, pela amizade e apoio na coleta de dados, que tanto contribuíram para o desenvolvimento deste trabalho.

À Prof ${ }^{a}$ Arlene Carvalho de Assis, pela atenciosa leitura de alguns rascunhos e pelas observações pertinentes.

À Prof ${ }^{\mathrm{a}}$ Darcy, pela criteriosa e rigorosa correção deste trabalho.

À UFG, pela liberação que me possibilitou condições de dedicação exclusiva para realização desta tese.

Muito obrigado a cada um e a todos! 


\section{SUMÁRIO}

INTRODUÇÃO

1. Campo temático, objeto de estudo e finalidade da pesquisa

2. Problemática e questões relevantes

3. O modo de investigação e de exposição

\section{CAPÍTULO I}

A REESTRUTURAÇÃO DA EDUCAÇÃO SUPERIOR NO BRASIL:

A reorganização do sistema e suas implicações no trabalho acadêmico, na dinâmica do campo e na reconfiguração das universidades federais

1. A reorganização do sistema de educação superior: sua lógica constitutiva

2. Alterações na produção do trabalho e da vida acadêmica

2.1 A subsunção formal e real do trabalho acadêmico ao capital

$2.2 \mathrm{O}$ trabalho acadêmico produtivo e improdutivo

3. A sociedade e o campo universitário: a universidade pública em questão

3.1 Reprodução e transformação no campo universitário

3.2 Ajuste, resistência e inovação no campo universitário

CAPÍTULO II

A UNIVERSIDADE FEDERAL DE GOIÁS (UFG) NO QUADRO DE METAMORFOSE DAS UNIVERSIDADES FEDERAIS

1. A identidade institucional em questão

2. A situação acadêmica da UFG

2.1 A estrutura e a administração superior

2.2 A comunidade universitária e a qualificação dos recursos humanos.

2.3 A graduação

2.4 A pós-graduação e a pesquisa

3. Sinais do processo de metamorfose institucional 
CAPÍTULO III

DESVELANDO O PROCESSO DE METAMORFOSE DA

UNIVERSIDADE FEDERAL DE GOIÁS (UFG):

o campo e sua produção

1. O movimento na área de gestão e financiamento

1.1 A questão do orçamento: histórico e perspectivas

1.2 Alterações no padrão de gestão e financiamento

1.2.1 A integração universidade-sociedade e a ampliação da receita própria

1.2.2 A problemática dos convênios e contratos

1.2.3 A prestação de serviços remunerados e os cursos de especialização

2. O movimento na área de avaliação

2.1 Programa de Avaliação Institucional das Universidades Brasileiras (Paiub) e Exame Nacional de Cursos (ENC): disputa e acomodação

2.2 Gratificação de Estímulo a Docência (GED): alterações e implicações

3. O movimento na área de currículo

4. O movimento na área de pesquisa e pós-graduação

4.1 Peculiaridades constitutivas da área

4.2 As pressões e tensões existentes

4.3 A problemática do controle e gerenciamento

4.4 As estratégias de consolidação, investimento e reconhecimento

CONSIDERAÇÕES FINAIS

REFERÊNCIAS BIBLIOGRÁFICAS

ANEXOS 


\section{Principais Siglas Utilizadas}

\section{Universidade Federal de Goiás (UFG)}

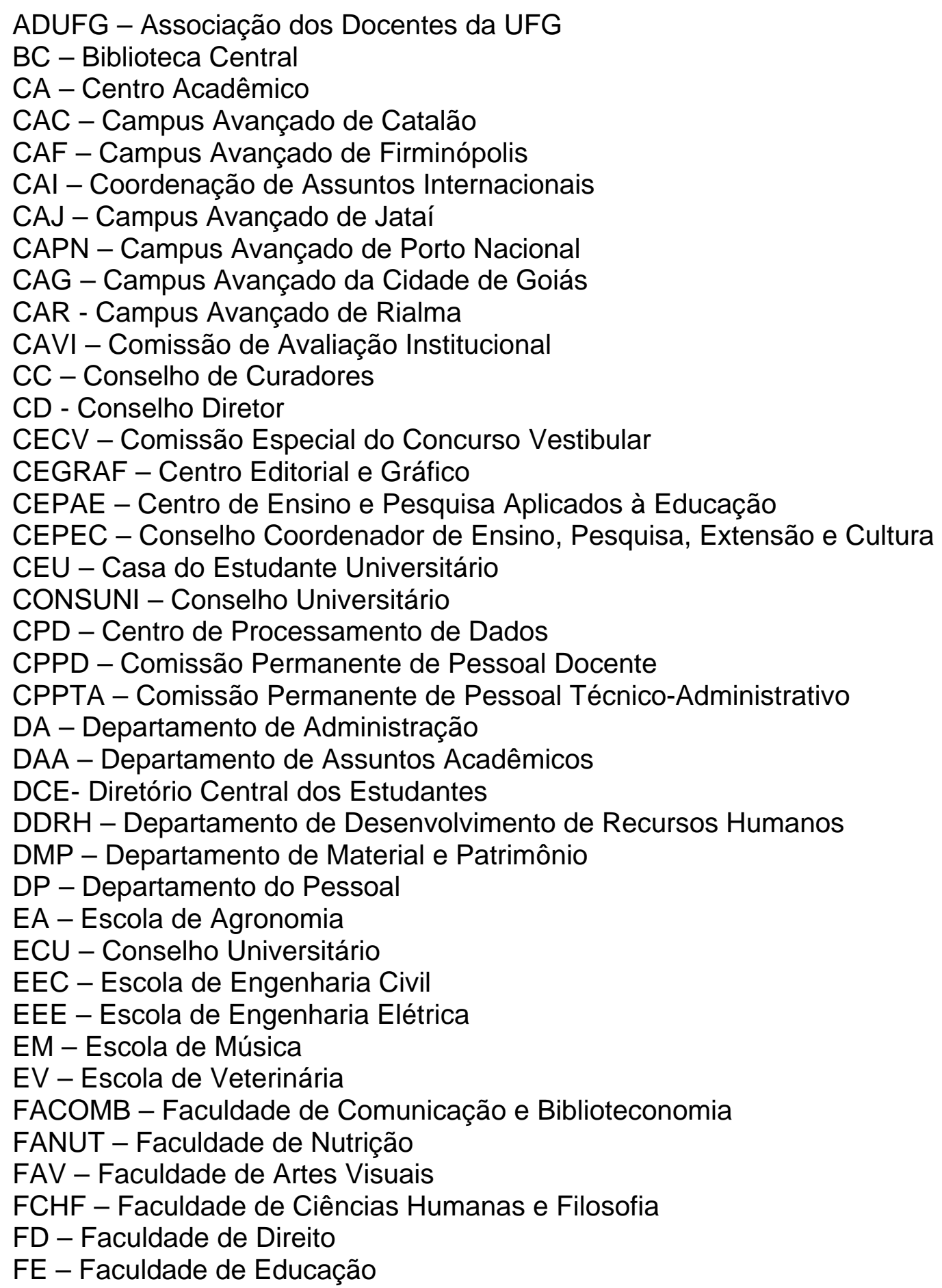




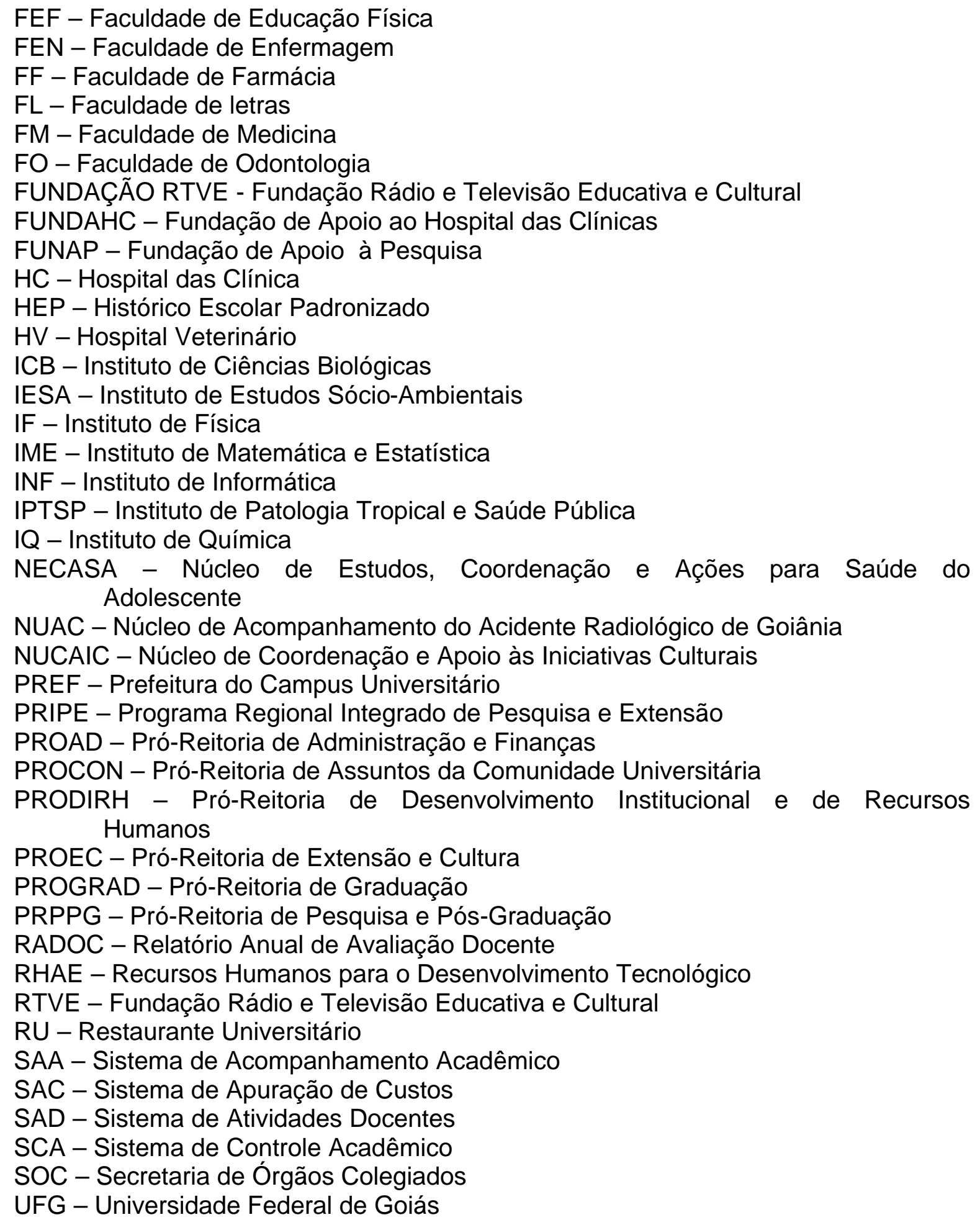




\section{Outras Siglas}

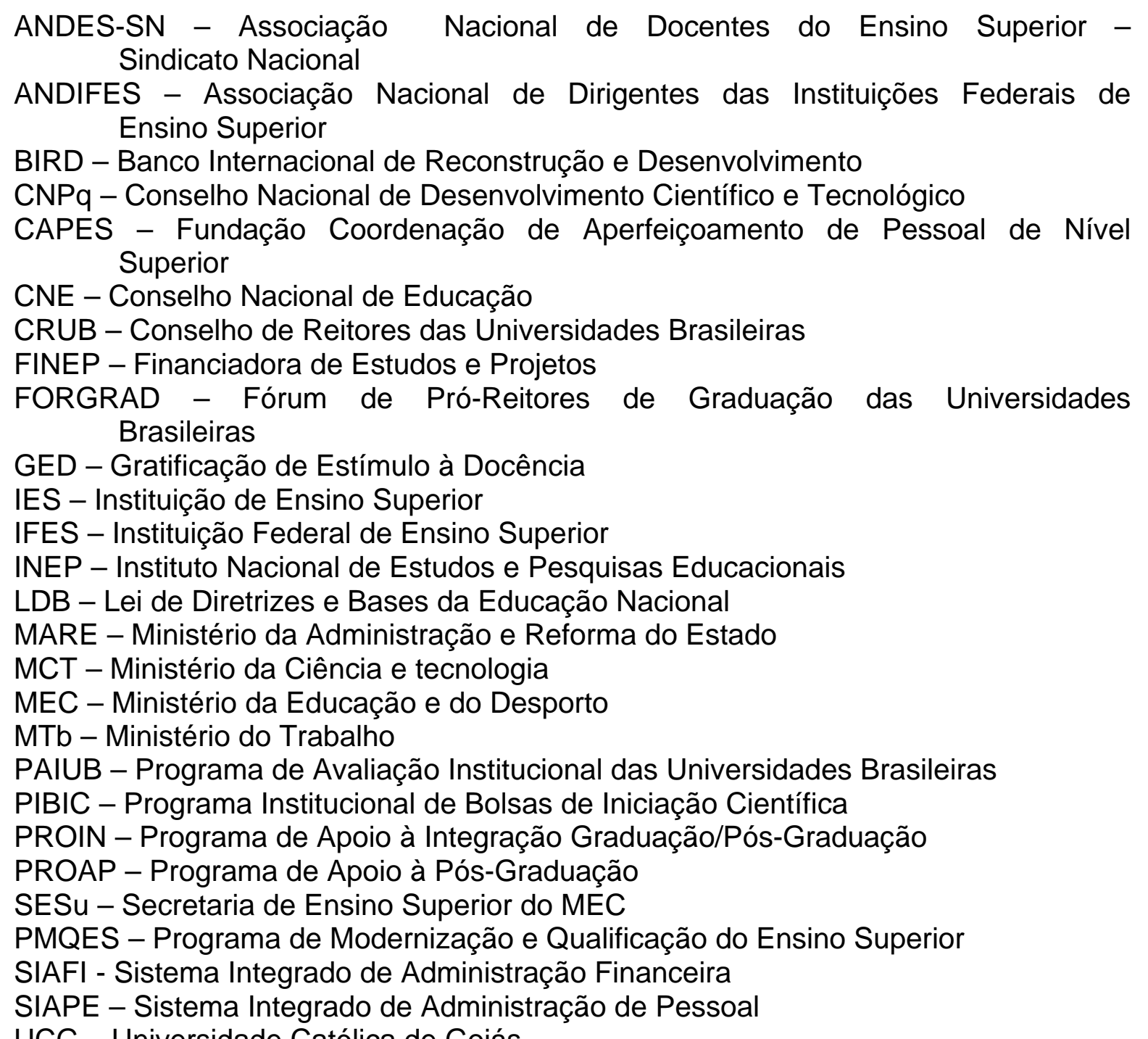
UCG - Universidade Católica de Goiás

UNESCO - United Nations Educational, Scientific and Cultural Organisation 


\section{Lista de Tabelas}

Tabela 1

Evolução do número de docentes e técnico-administrativos da UFG no período de março 1998 a dezembro de 1999

Tabela 2

Número de alunos matriculados e crescimento das matrículas

nos cursos de graduação da UFG, por ano letivo

Tabela 3

Número de vagas no vestibular da UFG e aumento de vagas,

por ano (1995 a 1999)

Tabela 4

Conceitos atribuídos pelo ENC aos cursos de graduação da UFG, por ano (1996 a 1999)

Tabela 5

Avaliação do corpo docente, organização didático-pedagógica

e instalações, por curso de graduação da UFG

Tabela 6

Número de cursos, concluintes, em 1995, matrícula e funções

docentes em 30/04, segundo amostragem regional das Ifes - 1996

Tabela 7

Número de vagas oferecidas, relação candidato/vaga, aprovados

e ingressos, segundo amostragem regional das Ifes - 1998 
Tabela 8

Programas de pós-graduação stricto sensu da UFG, conforme

data de criação, nível e conceito Capes (1994 a 1999)

Tabela 9

Orçamento da UFG - 1998

Tabela 10

Execução do orçamento da UFG - 1998

\section{Tabela 11}

UFG: execução orçamentária e financeira com pessoal,

custeio e capital no período 1994 a 1997 e no ano de 1998

Tabela 12

UFG: despesa com pessoal em 1997 e 1998

Tabela 13

UFG: total das despesas com custeio na execução

orçamentária de 1996 a 1998

Tabela 14

UFG: recursos executados por convênio no período 1994 a 1998

\section{Tabela 15}

Distribuição da Gratificação de Estímulo a Docência (GED) nas

Instituições Federais de Educação Superior e na UFG - 1998 


\section{Lista de Anexos}

Anexo 1

Observação sistemática nos conselhos e câmaras da UFG no período de fevereiro a dezembro de 1999.

Anexo 2

Número de unidades acadêmicas da UFG, por áreas de conhecimento e campi em Goiânia

Anexo 3

Reitores da UFG, conforme período de gestão

Anexo 4

Número de vagas ofertadas nos cursos de graduação da

UFG - 2000, por cursos e cidades

Anexo 5

Medidas e ações significativas na UFG: 1989-1999

Anexo 6

UFG: convênios assinados ou renovados no período de janeiro a dezembro de 1999

Anexo 7

UFG: cursos de graduação, números e anos das Resoluções

do Conselho de Ensino, Pesquisa, Extensão e Cultura (CEPEC),

por unidades de ensino e por áreas de conhecimento

Anexo 8

UFG: princípios e critérios norteadores na elaboração dos currículos plenos dos cursos de graduação, conforme reformas curriculares - décadas de 80 e 90 


\title{
INTRODUÇÃO
}

\begin{abstract}
Não há estrada real para a ciência, e só têm probabilidade de chegar a seus cimos luminosos, aqueles que enfrentam a canseira para galgá-los por veredas abruptas (Marx, 1996: 19).

Toda pesquisa cria para si um método adequado, uma lógica própria, cuja generalidade e universalidade consiste apenas em ser 'conforme ao fim' (Gramsci, 1999: 234-235).
\end{abstract}

As duas epígrafes, extraídas de dois autores clássicos bastante atuais, mostram que a pesquisa não possui uma estrada real e um método dados a priori. Este trabalho confirma, em grande parte, essa perspectiva. Nesse sentido, apresentam-se, inicialmente, a lógica e a trajetória metodológica de investigação do objeto de estudo, bem como as limitações enfrentadas nas veredas percorridas, o que se dá por meio de três tópicos fundamentais: a) campo temático, objeto de estudo e finalidade da pesquisa; b) problemática e questões relevantes; c) o modo de investigação e de exposição.

\section{Campo temático, objeto de estudo e finalidade da pesquisa}

Esta pesquisa situa-se no campo da educação superior e, mais especificamente, nas interligações e nas relações educação-reestruturação produtiva e Estado-políticas de educação superior. O ponto de partida da investigação é o processo de flexibilização, diversificação e diferenciação do sistema de educação superior que ocorre no Brasil, com mais intensidade, a partir do primeiro governo Fernando Henrique Cardoso (1995-1998). A preocupação mais ampla é, basicamente, compreender e avaliar o que acontece nas universidades públicas, especialmente nas federais, à luz das tensões históricas, dos desafios da sociedade contemporânea e das atuais políticas de educação superior, de modo a analisar as perspectivas concretas dessas instituições face ao contexto atual. 
O estudo busca identificar e interpretar as mudanças que se sucedem na organização do tempo-espaço das atividades acadêmicas e na identidade institucional da Universidade Federal de Goiás (UFG), com base em alterações que se processam nos padrões de gestão, financiamento, avaliação, currículo, pesquisa e pós-graduação. A UFG é tomada como caso exemplar do surgimento de novas relações de produção do trabalho acadêmico. Considerada como universidade de médio porte, sobretudo no conjunto das Instituições Federais de Ensino Superior (Ifes), verifica-se a presença de elementos fundamentais de uma nova dinâmica e de um novo pensamento institucional. A finalidade básica da pesquisa é, portanto, desvelar o atual cotidiano de metamorfose da UFG, considerando as determinações mais amplas que implicam a reconfiguração da identidade institucional e do trabalho acadêmico.

\section{Problemática e questões relevantes}

A conjuntura atual resulta, em grande parte, da crise geral do capitalismo nos anos 70 (particularmente do Estado do bem-estar e do modelo fordista-teylorista de produção), da intensificação do movimento de internacionalização do capital (especialmente do capital financeiro), da implementação de um modo mais flexível de acumulação capitalista e da adoção das políticas neoliberais, que preconizam o mercado como princípio fundador, unificador e auto-regulador da sociedade global competitiva. Nessa perspectiva, coloca-se a reforma do Estado e do sistema educativo no Brasil, propugnada pelos agentes multilaterais, objetivando reduzir a esfera pública e ampliar a esfera privada1. Essa conjuntura desempenha, também, papel

\footnotetext{
1 A esse respeito conferir, dentre outros: Chesnais (1996); Harvey (1992); Oliveira (1998); Rifkin (1995); Chauí (1999a); Silva Jr. e Sguissardi (1999a); Dourado e Oliveira (1999). Segundo Silva Jr. e Sguissardi (1999a), além dessa redução pelo viés privatista, as políticas públicas no Brasil passam por um processo de mercadorização do espaço estatal ou público e, no caso da educação superior, o movimento de reconfiguração tem como meta a reorganização desse espaço social, segundo a lógica do mercado, em meio à redefinição dos
} 
determinante no processo de redefinição da educação superior e, em especial, da universidade pública.

Dentre os temas mais significativos, presentes no debate internacional sobre educação superior, evidenciam-se a grande preocupação com a ampliação da demanda e a massificação da educação superior; as novas necessidades de uma demanda cada vez mais diversificada; os novos objetivos e funções da educação superior no século XXI; o lugar da universidade no mundo virtual das novas tecnologias da informação e da comunicação; o papel das ciências sociais na análise da problemática mundial; a integração/unidade entre pesquisa e ensino; a eficiência, a qualidade, a competitividade e a eqüidade dos sistemas; as mudanças nos perfis profissionais e no processo formativo; o papel da educação continuada na formação permanente; a autonomia das ciências e a liberdade acadêmica; a interdisciplinaridade; as relações das universidades públicas com o Estado e com o setor produtivo; o impacto da mundialização do capital nos planos e programas; o financiamento da educação superior; a relação entre investigação-tomada de decisões no campo da educação superior ${ }^{2}$

Essas temáticas explicitam diferentes elementos da conjuntura atual, bem como as novas tensões, exigências e desafios colocados à educação superior. Elas apontam, também, a necessidade de investigar e refletir sobre o papel da educação superior e das universidades em um contexto de mudanças aceleradas, especialmente, no tocante à produção de conhecimento e à formação. Nesse sentido, muitas questões podem ser formuladas. Como a universidade lida com os problemas contemporâneos? Que modificações estão ocorrendo nas universidades, particularmente nas públicas federais? Como se encontram a gestão, a organização acadêmica, os

conceitos de público e de privado, o que estaria promovendo um processo de mertilização do saber e do ensino. Nesse contexto, as modificações da natureza das Instituições de Ensino Superior (IES) tenderiam, por sua vez, a responder às demandas do mercado.

2 Sobre as principais temáticas internacionais, atualmente, no campo da educação superior consultar, dentre outros: Amaral (1998); Catani e Oliveira (1999b e 2000a); Paiva e Warde (1994); Yarzábal (1995). Além disso, ver Banco Mundial (1995) e Unesco (1998). 
currículos, a produção científica, a avaliação e o exercício da liberdade acadêmica em relação aos problemas e demandas atuais, particularmente à integração e os compromissos da universidade com a sociedade e com o país? As politicas de educação superior conseguem alterar a imagem e a identidade da universidade pública? De fato, há uma nova identidade sendo gerada no cotidiano acadêmico universitário? Que identidade é essa?

$\mathrm{Na}$ prática, a análise da reestruturação da educação superior no Brasil permite informar algumas dessas questões. Parece haver, nas atuais politicas de educação superior, uma lógica econômica e produtivista que implica uma remodelação do sistema, especialmente nas universidades federais. Os principios e as ações básicas dessa reforma, sobretudo na segunda metade da década de 90, são explicitados, em grande parte, nos documentos governamentais e textos legais (leis, decretos, portarias, resoluções, pareceres etc.).

De um modo geral, a diversificação e a diferenciação do sistema surgem como uma alternativa ${ }^{3}$ de solução para a demanda crescente de vagas nas universidades, e para a questão da massificação do ensino superior. A expansão do sistema, bem como a integração dos diferentes procedimentos de avaliação, credenciamento e recredenciamento, objetivando produzir um sistema baseado na flexibilidade, competitividade, diferenciação e avaliação, são adotadas como política fundamental do Ministério da Educação e do Desporto $(\mathrm{MEC})^{4}$ no campo da educação superior (Catani e Oliveira, 2000b).

Nesse sentido, o MEC vem estimulando o processo por meio, notadamente, de: a) criação de centros universitários, com autonomia para o desenvolvimento de atividades na área de ensino e formação profissional; b)

\footnotetext{
3 Ver notícia: Diversificação surge como alternativa. MEC/ Inep. Brasilia, 13 maio 1999. (www.inep.gov.br/noticias/news)

${ }_{4}$ A esse respeito, consultar dois artigos do ministro da educação, Paulo Renato Sousa, $A$ agenda positiva do ensino superior, publicado em O Estado de S. Paulo, 23 nov. 1998, p. A-2, e a Avaliação e expansão do ensino superior, publicado pela Folha de S. Paulo, em Tendências/Debates, 21 dez. 1999.
} 
regulamentação dos chamados cursos seqüenciais, isto é, cursos superiores de curta duração, voltados para uma formação profissional específica ou para complementação de estudos, como alternativa ao acesso da sociedade ao ensino de terceiro grau; c) flexibilização curricular que incentive o desenvolvimento de projetos pedagógicos mais específicos, procurando atender aos interesses regionais, combater a evasão, aumentar a participação dos setores que integram a formação e ampliar o espaço do aluno na definição de seu currículo, além de adequar os cursos às demandas do mercado de trabalho; d) instituição e consolidação do Exame Nacional do Ensino Médio (Enem), com a finalidade de diversificar o processo de acesso, oferecendo alternativa(s) de associação ou substituição do vestibular5; e) incentivo aos programas de ensino à distância, os chamados cursos virtuais, incluindo os cursos de graduação; f) definição de nova matriz de distribuição de recursos orçamentários (entre as Ifes) que privilegia o número de alunos efetivos na graduação ${ }^{6}$.

No caso das universidades federais, verifica-se uma série de políticas e processos que buscam ajustá-las ao programa de diversificação e diferenciação, que inclui crescente diminuição de recursos do governo federal para sua manutenção e, ao mesmo tempo, implementação e ampliação de novos mecanismos de controle. Ao que parece, embora já existisse um processo natural de heterogeneidade dessas instituições, havia e há mecanismos históricos de convergência que asseguram a unidade do sistema, como: indissociabilidade ensino-pesquisa-extensão, carreira única,

\footnotetext{
${ }^{5}$ Essas iniciativas estão organicamente formuladas na Sinopse Estatística do Ensino Superior Graduação - 1998, produzida pelo MEC/Inep (1Brasil. MEC/Inep, 1999a).

${ }^{6}$ Além dessas medidas, o MEC vem adotando uma política de expansão com a criação de centros universitários, faculdades integradas e instituições isoladas. Nos últimos quatro anos, o ministério autorizou a abertura de 117.584 vagas nessas instituições representando um aumento de $47 \%$ na oferta. Esse crescimento acontece de forma desordenada, uma vez que: a) se concentra na rede privada; b) se dá por meio da abertura de vagas em cursos relativamente baratos; c) ocorre nos cursos, nas cidades e regiões onde já há maior oferta de vagas; d) está implicando em perda da qualidade do ensino superior. A esse respeito consultar: Ensino brasileiro cresce torto. Folha de S. Paulo. 30 jan. 2000, p. 3; e A bolha universitária. Folha de S. Paulo. 1 fev. 2000.
} 
autonomia universitária, gestão democrática, avaliação institucional. No momento, no entanto, observa-se que está em curso a intensificação de um processo de diversificação e diferenciação, que ocasiona diferenças essenciais nas atividades, nos serviços, nos produtos e nas alternativas de solução para os problemas enfrentados. Além disso, essas diferenças começam a realçar uma maior competição no campo das universidades federais, especialmente porque contribuem para a busca de uma maior distinção institucional.

Urge, portanto, investigar essa situação, considerando especialmente a organização da produção universitária, a vida acadêmica e a especificidade histórica e social de cada instituição, observando como agem e reagem nesse contexto. Em outras palavras, é preciso apreender a especificidade de cada universidade no que toca à cultura institucional e ao processo de produção e socialização do conhecimento, como expressão da reforma da educação superior por meio das politicas públicas.

Assim, o trabalho de investigação não pode perder de vista a complementaridade entre dois pólos fundamentais. De um lado, as atuais politicas de educação superior, que procuram alterar a natureza das universidades e do trabalho acadêmico. De outro, o comportamento de cada universidade, expresso por meio de seus processos, movimentos e tendências. Com base nessa compreensão, pode-se pensar a identidade própria de cada instituição, bem como os rumos das universidades públicas no Brasil, especialmente das federais ${ }^{7}$.

\footnotetext{
7 O termo metamorfose institucional, adotado nesse estudo, exprime o atual estado de mudança observado no modo de ser e de agir das universidades federais. Indica, assim, as novas formas, feições e estruturas que estão se processando no sentido de transformar, em especial, a gestão universitária e o trabalho acadêmico dessas instituições. Expressa, ainda, uma dinâmica de alteração que vem procurando tornar as universidades federais em uma coisa diferente do que são.
} 


\section{O modo de investigação e de exposição}

Parece possivel captar essa realidade, ou melhor, esse estado de mudança das universidades federais valendo-se de diferentes perspectivas teórico-metodológicas ${ }^{8}$. No entanto, a preocupação deste estudo centra-se, sobretudo, nos aspectos qualitativos presentes em elementos acadêmicos que organizam e expressam, em grande parte, o tempo-espaço do trabalho acadêmico na instituição universitária, como: as formas de gestão, os mecanismos de financiamento, a avaliação institucional, os currículos de formação dos profissionais e a produção científica ${ }^{9}$. Esses elementos estão intensamente presentes nas politicas de educação superior e no cotidiano de produção do trabalho acadêmico. Eles se apresentam como porta de entrada dessa nova lógica de reestruturação da educação superior no Brasil, uma vez que parecem ser mais permeáveis às mudanças nas relações de produção do trabalho acadêmico. Por isso, no âmbito da UFG, a apreensão dos movimentos e processos de mudança envolve uma análise do cotidiano, que permite revelar as práticas habituais, as complicações e os embates centrais do processo de metamorfose institucional, em consonância com as determinações mais amplas e contraditórias da esfera de produção da sociedade capitalista.

O pressuposto presente neste trabalho refere-se à universidade como uma instituição social, científica e educativa, cuja identidade está fundada em principios, valores, regras e formas de organização que lhe são inerentes. Seu reconhecimento e sua legitimidade social vinculam-se, historicamente, à sua capacidade autônoma de lidar com as idéias, de buscar o saber, de

\footnotetext{
8 Consideram-se as possiveis e diferentes formas de aproximação do objeto de estudo, particularmente os estudos descritivos e quantitativos, de natureza positivista, e os estudos do cotidiano, como: pesquisa-ação, pesquisa participante, estudo etnográfico etc.

9 Avaliação, gestão, financiamento e currículo são elementos amplamente indicados pela literatura nacional e internacional como objetos de intervenção das reformas educativas nas décadas de 80 e 90, tanto na Europa como na América Latina. No Brasil, uma evidência da relevância desses elementos é o Plano Nacional de Educação (Brasil. MEC/Inep, 1998c), em que a maior parte das metas para a educação superior refere-se a esses elementos.
} 
descobrir e de inventar o conhecimento. Nesse processo, a universidade interroga, reflete, critica, cria e forma, exercendo papel fundamental no avanço e na consolidação da democracia, que implica compromisso com a luta pela democratização dos meios de produção da vida humana (Chauí, 1998). A atualização da universidade acontece por meio dessa capacidade histórica de estar imersa em condições objetivas dadas, em cada tempoespaço, mantendo-se fiel à sua natureza e motivada pela sua vocação primeira: a de ser um campo de reflexão, crítica, descoberta e invenção do conhecimento novo, comprometido com a construção e consolidação de uma sociedade democrática ${ }^{10}$.

Uma das hipóteses deste trabalho é que se a universidade exercitar cotidianamente essa identidade histórica, poderá contribuir para criar obstáculos às demandas e às exigências do mercado, no tocante ao processo de ajustamento em curso. Em outras palavras, a natureza da universidade, a especificidade pedagógica, a complexidade do trabalho acadêmico, bem como o capital intelectual e cultural acumulado nas universidades federais, comprometidos com o interesse coletivo e com a expansão da esfera pública, podem concorrer para obstruir ou alterar, significativamente, a generalização dos interesses econômicos, das demandas privadas e da lógica mercantilista, presentes na atual reforma da educação superior, de modo a provocar, impossibilitar ou redirecionar o projeto de universidade.

Além disso, supõe-se que as respostas das universidades federais ao processo de reorganização e ajustamento do sistema poderão e deverão ser diferenciadas. Cada instituição universitária e, mais ainda, cada unidade de ensino (faculdade, instituto, escola etc.) em razão dos campos de trabalho, da

\footnotetext{
10 Entende-se que, quando a universidade abre mão da identidade histórica, ela corre o risco de servir, mais diretamente, a propósitos de reprodução do poder e das estruturas existentes e não à sua transformação. Nesse sentido, pode tornar-se mais funcional, operacional e passiva diante do instituído, participando da estrutura de poder social e contribuindo com as estratégias de conservação da ordem social. Com isso, ela nega e compromete sua existência, tendo em vista que perde sua autonomia, ganha uniformidade e subordina-se aos interesses diretos do Estado e/ou do mercado.
} 
cultura institucional ${ }^{11}$, dos acordos e das disputas acadêmicas, políticas, culturais e profissionais (internas e externas) age e reage de maneira singular às demandas da sociedade contemporânea, às políticas educacionais e às pressões e possibilidades regionais e locais. Os jogos, os rituais e as disposições acadêmicas, que encerram transações, rivalidades, delimitação de territórios, competências e a afirmação de pessoas, grupos e áreas do saber, podem contribuir para o processo de metamorfose da universidade, tanto quanto pode impossibilitá-lo ou alterá-lo.

Por isso, entende-se que o processo de metamorfose da UFG pode ser apreendido, em grande parte, no cotidiano da organização do tempo-espaço do trabalho acadêmico ${ }^{12}$, especialmente nos principais colegiados de decisão, na legislação produzida, nos documentos informativos e orientadores das políticas implementadas na instituição, e nos comentários e informações que ocorrem por ocasião das reuniões dos conselhos e câmaras regimentais de deliberação e, ainda, por meio da identificação e análise crítica das principais ações e medidas tomadas na universidade, particularmente na década de 90. O acompanhamento sistemático dos pleitos e debates dos segmentos organizados da comunidade universitária, bem como as conversas informais, especialmente com gestores acadêmicos e membros dos colegiados de decisão, também são importantes para a compreensão do quadro atual e dos processos de metamorfose em curso na instituição.

\footnotetext{
$11 \mathrm{O}$ termo cultura institucional indica aqui, de um lado, as coisas instituídas, ou seja, a estrutura, as normas de ação, os códigos etc. e, de outro, as instituintes, ou seja, a vida cotidiana, com seus valores, práticas, rituais etc., produzida historicamente. Esse termo expressa, portanto, a base para a identificação da instituição, além de informar o modo como as coisas são feitas e os seus significados.

12 Nesse sentido, entende-se, ainda, que o trabalho acadêmico organiza-se valendo-se de práticas e rotinas diárias que são, em boa medida, planejadas, ordenadas, modeladas e controladas num tempo-espaço próprio e inerente ao campo científico, à natureza de cada instituição universitária, bem como à sua forma de organização. Todavia, parece evidente que o tempo-espaço pode exprimir uma multiplicidade de práticas e significados construídos ou em construção, além de ocultar ambigüidades, contradições e lutas. Do mesmo modo, o trabalho acadêmico e a gestão universitária podem conformar-se a uma perspectiva racionalizante e mercantil próprias da atual fase de compressão do tempo espaço (Harvey, 1992), da aceleração contemporânea e da constituição do meio técnico-científico informacional (Santos, 1997).
} 
Além disso, um olhar analítico do cotidiano da UFG permite expor, em boa medida, os movimentos, as tensões e os embates contraditórios desse processo de metamorfose institucional. Cada área organizadora do tempoespaço da universidade apresenta especificidades e uma lógica interna que deve ser compreendida singularmente em seus movimentos (produção, tensões, contradições, disputas, estratégias etc). Nesse sentido, realiza-se análise pormenorizada dos processos, movimentos e tendências nas áreas de gestão, financiamento, avaliação, currículo, pesquisa e pós-graduação, objetivando obter uma visão mais abrangente e totalizadora da metamorfose institucional.

O plano de investigação e de exposição contemplam, ao longo do estudo:

a) ampliação e sistematização permanente da literatura referente ao objeto de estudo, em especial ao campo da educação superior;

b) levantamento e análise da legislação sobre educação superior, especialmente a partir do primeiro governo de Fernando Henrique Cardoso (1995-1998), consultando-se Diário Oficial da União, Internet e periódicos especializados em legislação de ensino;

c) levantamento e análise de documentos (oficiais e não-oficiais, publicações técnicas, artigos de jornais, periódicos e outros), legislação e atas produzidas pelos conselhos e câmaras de deliberação da UFG (Conselho Universitário; Conselho de Ensino, Pesquisa, Extensão e Cultura; Conselho de Curadores; Câmara de Graduação; Câmara de Extensão; Câmara de Ensino, Pesquisa, Extensão e Cultura); este trabalho centra-se no período 1989-199913, o que contempla os três últimos reitorados, objetivando apreender os principais processos e movimentos de metamorfose

\footnotetext{
${ }^{13}$ A análise do caso revelou ser esse o período de maior relevância da instituição em termos de medidas mais significativas, no âmbito da gestão universitária, indicativas de um processo de modelação e de metamorfose institucionais (anexo 5). A definição do período também foi importante, porque permitiu visualizar e caracterizar a UFG antes do primeiro governo de Fernando Henrique Cardoso (1995-1998), ou seja, antes da atual reforma da educação superior. Assim, é possivel comparar, em série histórica, os principais processos e movimentos da instituição, como evidencia o anexo 5 .
} 
institucional que dão especificidade ao caso no contexto da reforma da educação superior;

d) observação sistemática de reuniões dos conselhos e câmaras da UFG, no período de fevereiro de 1999 a dezembro de 199914, perfazendo um total de 142 horas (anexo 1), buscando apreender criticamente as alterações que se processam no cotidiano de gestão da universidade, considerando as suas condições objetivas no contexto da reforma;

e) entrevistas abertas e conversas informais com pró-reitores, diretores, coordenadores e professores, com a finalidade de complementar os dados e os objetivos da análise documental e da observação sistemática.

Há, evidentemente, limitações em trabalho dessa amplitude, haja vista que a metamorfose das universidades públicas federais ocorre ao mesmo tempo da implementação da reforma da educação superior no Brasil. Esta pesquisa acontece, portanto, em um momento de reconfiguração do sistema de educação superior e de transformação do modo de ser e de agir das universidades públicas federais. Trata-se, portanto, de um período de transição em que a mudança no estado de ser e de agir permite vislumbrar formas, estruturas e conteúdos que podem se modificar. Em outras palavras, as feições, a natureza e as finalidades das universidades federais estão em processo de (re)construção.

Um outro desafio ao pesquisador diz respeito às dificuldades de obtenção de dados ainda mais qualitativos, ou seja, que expressem com mais intensidade o cotidiano de produção do trabalho acadêmico, nas diferentes unidades da UFG e que, portanto, sejam capazes de permitir uma análise mais pormenorizada das práticas diárias que contribuem para o processo de metamorfose da universidade, em geral. Evidentemente que, para captar as disputas, os movimentos e os processos de metamorfose de cada unidade

\footnotetext{
14 Observou-se também Assembléias universitárias e Assembléias da Associação de Docentes da UFG (Adufg). Além disso, acompanhou-se ainda reuniões do Conselho Universitário (Consuni) e Conselho de Ensino, Pesquisa e Extensão (Cepec), no decorrer do primeiro semestre de 2000, objetivando complementar e confirmar dados.
} 
acadêmica, em sua especificidade, seria preciso realizar uma outra pesquisa em que, provavelmente, se definiria nova forma de investigação contemplando mais recursos e um tempo maior para realização.

A questão do poder na universidade constitui-se em outro aspecto de grande importância no quadro de metamorfose da instituição. Entendeu-se, no entanto, ao longo da investigação, que essa temática devia ser tratada com maior profundidade, uma vez que guarda especificidades que extrapolavam os limites desse trabalho. Todavia, é preciso registrar que a observação sistemática nos conselhos e câmaras de deliberação da universidade apresentam-se como locus privilegiado para compreensão das disputas internas atuais que encontram sua razão de ser, muitas vezes, na história de constituição do poder e no estabelecimento de políticas e ações na instituição.

A estruturação da pesquisa delineou-se no processo de investigação, de organização e análise dos dados. O formato de exposição que ganhou maior sentido didático foi o de apresentar o estudo em três capitulos fundamentais.

O primeiro capítulo expõe o processo de reorganização da educação superior, enfatizando a dinâmica de metamorfose das universidades federais, especialmente no tocante à produção acadêmica do campo, o que se realiza com base em: a) exame da lógica de reestruturação da educação superior, identificada por meio de um processo de reorganização do sistema; b) análise das alterações na produção do trabalho e da vida acadêmica; c) exposição dos elementos mais significativos dos embates do campo científicouniversitário, especialmente daqueles que evidenciam as forças de ajuste, resistência, improvisação ou inovação presentes no atual movimento de construção e reconstrução das universidades federais. O capítulo enfatiza, portanto, alguns dos elementos determinantes do novo processo de reorganização da educação superior no Brasil. Para sua elaboração, procedeuse a uma análise dos documentos e das pesquisas, ensaios e artigos sobre a deflagração, implementação e efeitos da reforma da educação superior, 
sobretudo nas universidades públicas. Além disso, em razão da natureza da problema, considerou-se fundamental analisar as alterações na produção do trabalho e da vida acadêmica à luz de alguns elementos da teoria do valortrabalho de Marx, bem como discutir as possibilidades e as perspectivas do processo de metamorfose da universidade pública, com base na teoria de campo, de Bourdieu. Nesse percurso, acentuam-se os processos de mudança da educação superior, que consubstanciam certo ajustamento às politicas governamentais e às demandas do mercado, bem como uma crescente mercantilização desse nível de ensino.

O segundo capítulo procura caracterizar e analisar criticamente a UFG no quadro de metamorfose das universidades federais. Para tanto, discute as funções, a natureza e as finalidades acadêmicas das universidades federais no contexto atual de redefinição de identidades institucionais, apresenta a situação acadêmica da UFG e aponta alguns dos sinais da especificidade do caso, indicadores do processo de metamorfose. $\mathrm{O}$ entendimento que orienta esse capítulo é que o processo de ajustamento da universidade só pode ser melhor percebido quando a instituição ganha maior visibilidade institucional e organizacional e quando a especificidade e a importância do caso são revelados em seus pormenores. É exatamente esse retrato da condição histórica da UFG, pintado com a descrição analitica de alguns dos seus principais indicadores acadêmicos, que se procurou desenvolver. Esse capítulo foi construído, sobretudo, com base em documentos primários que expressam as politicas de educação superior para as universidades federais, além daqueles que explicitam a situação acadêmica da UFG, sendo importante, ainda, lançar mão das anotações de entrevistas, de observações e do levantamento de dados in loco.

O terceiro capítulo busca desvelar o processo de metamorfose da UFG, bem como evidenciar a dialética presente nas ações e reações advindas dos processos de ajuste, resistência, improvisação ou inovação, enfatizando o campo e sua produção. O processo de metamorfose é focalizado mediante 
análise crítica e interpretativa dos seguintes elementos organizacionais do tempo-espaço do trabalho e do cotidiano acadêmico: gestão, financiamento, avaliação, currículo, pesquisa e pós-graduação. Esses elementos são considerados fundamentais, seja pelas reformas e politicas educacionais, seja pela importância revelada no caso em estudo, em razão de serem mais sensiveis às pressões internas e externas, mais móveis e mais plásticos em relação às demandas e exigências atuais, alterando-se com mais intensidade e visibilidade. A base para a organização do capitulo foram as observações sistemáticas nos conselhos e câmaras da UFG (anexo 1), as conversas informais, a análise das resoluções, atas e documentos da universidade e, ainda, os dados complementares coletados ao longo da investigação. A construção apropriou-se, no entanto, dos elementos teóricos explicitados nos capitulos anteriores, além de desenvolver uma exposição tomando-se por base a noção de metamorfose e de produção do cotidiano institucional.

Finalmente, as considerações finais retomam, em linhas gerais, o processo de reestruturação produtiva e de reforma do Estado, as atuais politicas de reorganização e de ajustamento da educação superior, os processos de metamorfose da gestão e do trabalho acadêmico e outros condicionantes do estado de mudança das universidades federais e da UFG, em particular. Desse modo, busca-se apreender o objeto de estudo nos aspectos principais e gerais, procurando resgatar e colocar em novos patamares as discussões sobre as universidades federais e sobre a UFG, em especial, objetivando avançar o debate na área e contribuir, criticamente, para a construção de uma universidade pública, democrática, autônoma e de qualidade no Brasil. 


\section{CAPÍTULO I}

\section{A REESTRUTURAÇÃO DA EDUCAÇÃO SUPERIOR NO BRASIL: a reorganização do sistema e suas implicações no trabalho acadêmico, na dinâmica do campo e na reconfiguração das universidades federais}

O Capitulo I tem a finalidade de explicitar alguns dos elementos centrais da reestruturação da educação superior brasileira, empreendida a partir do primeiro governo Fernando Henrique Cardoso (1995-1998), bem como os seus efeitos nas universidades públicas, especialmente nas federais, objetivando concretizar três importantes tarefas: a) possibilitar uma compreensão do processo de reorganização da educação superior no Brasil e da lógica subjacente à reforma, deflagrada no governo Fernando Henrique Cardoso, que institui, em grande parte, a dinâmica de metamorfose das universidades federais; b) analisar o impacto da reestruturação da educação superior no processo de produção do trabalho e da vida acadêmica nas universidades federais; c) procurar apreender o movimento social e acadêmico de construção e reconstrução das universidades federais, com base nos embates político-acadêmicos e na nova dinâmica do campo científico-universitário, evidenciando as possibilidades de ação e reação dessas instituições no contexto atual.

\section{A reorganização do sistema de educação superior: sua lógica constitutiva}

O propósito deste item é explicitar a dinâmica de ajustamento das universidades públicas à nova lógica de reorganização do sistema de educação superior no Brasil, o que significa compreender, em grande parte, o conteúdo das politicas públicas e educacionais que objetivam essa 
reorganização e que institui, em grande medida, o processo de ajustamento e de metamorfose das universidades federais.

A elucidação do que se pretende comunicar com as expressões a nova reorganização da educação superior no Brasil e o processo de ajustamento das universidades públicas federais pode, inicialmente, ajudar a esclarecer a leitura. Essas expressões indicam que há uma tensão e uma dialética nos processos de reorganização e de ajustamento. A reforma atual da educação superior impõe um modelo e uma lógica organizacionais que encontram resistência no sistema, especialmente nas universidades federais. Como instituições sociais educativas com inúmeras semelhanças, as reações e as respostas das universidades são generalizadas ${ }^{15}$, mas como instituições com histórias, imagens, identidades e correlações de forças singulares comportam-se de modo diverso, significando que o processo de ajustamento e de metamorfose é diferente em cada universidade, hipótese fundamental que será aprofundada mais adiante.

A análise da reforma evidencia que a educação superior se estrutura com base em um processo de reorganização e de ajustamento do atual sistema, decorrente, em grande parte, da reforma universitária de 1968 (Lei no 5.540/68). Com esse processo, pretende-se atingir, pelo menos, dois objetivos - o da diversificação e o de que cada instituição deverá repensar, redefinir seu caráter e sua vocação ${ }^{16}$. Com a diversificação do sistema, isto é, com a diferenciação das instituições e, conseqüentemente, dos serviços que elas devem oferecer a diferentes clientes, pretende-se reorientar o sistema em uma direção oposta à da reforma de 1968 no que tange, sobretudo, a estruturação de um modelo único que associa ensino-pesquisa-extensão. Aquela procurou formular diretrizes e desenvolver ações que permitissem

\footnotetext{
15 As greves de 1996 e 1998 nas universidades federais, especialmente a última, conseguiram paralisar a quase totalidade das Instituições Federais de Ensino Superior (Ifes). 16 Ver o documento: Uma nova politica para o ensino superior brasileiro: subsidios para discussão, apresentado pelo MEC aos reitores das universidades federais, em dezembro de 1996 (Brasil. MEC, 1996).
} 
construir um ambiente univesitário mais homogêneo e unificado nacionalmente. O modelo único tinha como princípio básico a indissociabilidade ensino-pesquisa-extensão, o que significava que as universidades deveriam institucionalizar a pesquisa e articulá-la com o ensino e com os serviços de extensão ${ }^{17}$.

$\mathrm{Na}$ reforma atual, entende-se que o modelo único esgotou-se e é incapaz de adaptar-se às novas condições da economia mundial (Brasil. MEC, 1996), já que é inerte e bastante impermeável às demandas, exigências e desafios contemporâneos. Por isso, para o governo Fernando Henrique Cardoso, faz-se necessário flexibilizar e diversificar a oferta de educação superior, de maneira que possibilite surgir outros formatos institucionais e organizacionais e que as instituições existentes, em especial, as universidades, possam redefinir sua identidade e desenvolver competências mediante o estabelecimento de vínculos com as demandas e exigências do regional, do local, do setor produtivo e do mercado de trabalho.

Um outro aspecto central dessa pressão representa a redefinição do relacionamento entre Estado e sistema de educação superior, notadamente, federal. Por um lado, o Estado aumenta paulatinamente sua função avaliadora e coordenadora do sistema, tornando-se basicamente um Estado avaliador e gestor do sistema (Sguissardi, 1997; Silva Jr., 1998; Catani, 1998; Fanneli, 1999; Chauí, 1998). Por outro, diminui a sua função de mantenedor das Instituições de Ensino Superior (públicas e gratuitas) ${ }^{18}$, ao mesmo tempo que as pressiona, com o objetivo de racionalização dos gastos, de estabelecimento de uma estrita avaliação da relação custo-benefício e de

\footnotetext{
$17 \mathrm{O}$ modelo único também recebe o nome de universidade de pesquisa (Durham, 1998a) ou universidade de campo (Cunha, 1997). A denominação universidade de pesquisa surgiu na década de 80 em contraposição à universidade de ensino. Já a denominação universidade de campo é usada por Cunha em contraposição à universidade especializada por área do saber, que começa a surgir no país.

$18 \mathrm{O}$ atual panorama da educação superior já possui instituições estatais que não podem ser caracterizadas como públicas e gratuitas. No âmbito municipal e, mais presentemente, em âmbito estadual, há instituições de educação superior que cobram mensalidades dos alunos, bem como vendem serviços e produtos (Dourado, 1997).
} 
diversificação de suas fontes de financiamento, sobretudo, mobilizando maior volume de financiamento do setor privado ${ }^{19}$.

Esses aspectos estão diretamente vinculados a um outro, não menos importante, o da autonomia universitária, sem a qual, nos moldes formulados pelo governo ${ }^{20}$, não é possivel a intensificação do processo de diversificação e diferenciação, mormente no interior das universidades federais. A autonomia, sem recursos perenes para manutenção do sistema público federal, contribuiria para que as instituições buscassem redefinir sua vocação, já que, para o MEC, o aumento crescente de custos torna o sistema financeiramente inviável. Por isso, "a autonomia cria uma oportunidade insubstituivel para a correção dessas distorções, tornando as instituições financeiramente viáveis e socialmente produtivas" (Brasil. MEC, 1996: 48)21.

Percebe-se, portanto, como afirma Cury (1997), que a atual reforma está estruturada em torno de dois grandes eixos: a avaliação e a autonomia. $\mathrm{Na}$ ótica governamental, as avaliações do rendimento acadêmico dos alunos, ao final dos cursos, e das instituições de educação superior devem indicar as mudanças que se fizerem necessárias. Já a autonomia tem por objetivo assegurar ampla flexibilidade, especialmente às universidades, que passam a

19 O objetivo maior dessas alterações, no caso das Ifes, é forçar um aumento de vagas nos cursos de graduação, sem que seja necessário ampliar recursos e repor ou aumentar o número de professores e técnico-administrativos. A idéia do Contrato de Desenvolvimento Institucional, presente na proposta de autonomia universitária do MEC (Brasil. MEC, 1999a e b), encaminha-se, exatamente, na direção do estabelecimento de metas de ampliação das vagas nos cursos de graduação. Antes disso, porém, as mudanças ocorridas no modelo de distribuição dos recursos entre as Ifes, implementadas pelo MEC em junho de 1999, já levavam em conta os quesitos ensino $(90 \%)$ e pesquisa $(10 \%)$, evidenciando a prioridade do governo federal no processo de reestruturação do sistema federal.

${ }^{20}$ A esse respeito, consultar PEC - 370/A, de 1996, e o documento sobre fundamentos para lei que regule a autonomia universitária, de abril de 1999, nos quais o MEC apresenta as diretrizes de autonomia universitária que devem constar do projeto de lei que amplia a autonomia mediante contrato de desenvolvimento institucional (Brasil. MEC, 1999a e b).

21 É fundamental observar que há uma concordância entre a atual política do MEC e as orientações do Banco Mundial para a reforma da educação superior. O Banco Mundial (1995: 4) sugere: "Fomentar a maior diferenciação das instituições, incluindo o desenvolvimento de instituições privadas; proporcionar incentivos para que as instituições públicas diversifiquem as fontes de financiamento, por exemplo, a participação dos estudantes nos gastos $e$ a estreita vinculação entre o financiamento fiscal e os resultados; redefinir a 
ter várias atribuições livres de controles dos sistemas de ensino. A esse respeito, Cury (1997: 18) diz que essa reforma poderá atender pelo nome de autonomia universitária avaliada e, ainda, alerta:

\begin{abstract}
A responsabilidade é grande, pois, além de cessar, via orçamento global, o fluxo contínuo (sic!) de recursos ao sabor de injunções nem sempre adequadas às diferenciações institucionais, é preciso saber se esses dispositivos conduzem a uma qualidade maior e melhor das instituições universitárias. O princípio de avaliação, em tese, conduziria a um estado permanente de aperfeiçoamento em que a flexibilidade permitiria perfis menos rígidos e mais abertos às peculiares condições das instituições. Flexibilidade e avaliação desde que montadas sob a égide da colaboração institucional entre os sujeitos interessados de tal maneira que o diálogo seja prévio a todas as implementações estruturantes da autonomia universitária. (sic do autor)
\end{abstract}

Parece evidente que, apesar da preocupação com o fluxo contínuo de recursos, com a qualidade das instituições universitárias e com a colaboração e o diálogo institucional na implementação de medidas de avaliação e de flexibilidade, Cury (1997) vê como positiva a constituição de um sistema de avaliação da educação superior e autonomia/flexibilidade que produzam diferenciações institucionais ${ }^{22}$. Idêntica é a posição de Martins (1998), que defende uma maior diversificação do sistema e o reconhecimento acadêmico das diferenças institucionais existentes, objetivando, sobretudo, a expansão necessária ${ }^{23}$.

Os dois pólos (flexibilidade e avaliação) expressam, na prática, uma tensão permanente sobre o sistema de educação superior. Se, por um lado, a

função do governo no ensino superior; adotar politicas destinadas a dar prioridade aos objetivos de qualidade e eqüidade".

22 Essa é, provavelmente, uma posição que encontra ressonância em diferentes meios acadêmicos, inclusive no interior das universidades públicas federais, o que facilita o processo de implementação da reforma.

23 A necessária expansão do ensino superior também é defendida por Francisco C. de Sá Barreto, Reitor da UFMG, para quem "está claro que o crescimento do ensino superior no futuro próximo, em qualquer uma das alternativas estimadas, não poderá basear-se no crescimento exclusivo do setor público e deverá se apoiar fortemente no setor privado". E, dentre as alternativas para crescimento do alunado, sugere maior agilidade na autorização de novos cursos, implantação de cursos seqüenciais, investimento no ensino à distância, expansão dos centros universitários, autonomia das Ifes, crescimento das universidades privadas e um novo projeto acadêmico como elemento indutor da ampliação de vagas (Barreto, 1999). 
flexibilidade parece desorganizar o sistema, por outro, a avaliação parece chamá-lo, sempre, à ordenação e à funcionalidade em torno de finalidades estabelecidas pelas políticas governamentais (e pelo mercado) para esse nível de ensino. Um olhar mais atento, todavia, permite ver, em que pese a tensão da avaliação permanente sobre o sistema, que a avaliação se orienta na direção de incentivar e consolidar o modelo da diversificação e diferenciação da educação superior, especialmente das universidades públicas federais. Em outras palavras, não basta diversificar a oferta de educação superior, já que o governo considera que é preciso diferenciar os produtos e serviços ofertados, possibilitando escolhas adequadas aos usuários ou consumidores dos serviços e produtos acadêmicos, o que significa que as universidades, mormente as federais, devam adquirir a feição de uma organização social orientada pela lógica da operacionalidade, produtividade e flexibilidade, diferindo radicalmente da universidade como instituição social, na proposição de Chauí (1998: 27-31).

A reorganização da educação superior parece ter uma finalidade clara: o ajustamento das universidades a uma nova orientação politica e uma nova racionalidade técnica. A nova orientação politica, além dos aspectos já considerados, parece implicar uma indução, ou melhor, uma crescente subordinação das universidades às regras do mercado, mediante a competição pelo autofinanciamento, o que, provavelmente, poderá transformá-las em instituições ou empresas, preocupadas com a própria sobrevivência e/ou obtenção de dividendos (Warde, 1997), e, ainda, alterar a identidade, o papel institucional, os compromissos sociais e a concepção de universidade pública. A nova racionalidade técnica (Santos, 1997), por sua vez, envolve movimento coordenado para levar as IES a se especializarem em uma tarefa ou em uma área de competência que lhes permitam potencializar os recursos de que dispõem, a fim de obterem maior eficiência e competitividade, bem como o máximo de produtividade. Na prática, então, há um empreendimento para racionalizar o sistema de educação superior, ou 
seja, organizá-lo nos moldes dos princípios da produção capitalista, a fim de torná-lo mais eficiente, competitivo e produtivo, de maneira, portanto, a dar resposta ao novo estilo de desenvolvimento científico e tecnológico e às necessidades do capital produtivo.

Essa racionalização do sistema de educação superior vem ocorrendo por meio de uma divisão por campo ou área de atuação institucional e, por conseqüência, por uma divisão do trabalho acadêmico. Na reforma deflagrada (Cunha, 1997), as instituições são levadas a ter natureza jurídica e organização acadêmica diferenciadas ${ }^{24}$. Além da divisão entre instituição de pesquisa e instituição de ensino, com diferentes graus de autonomia, há subdivisões quanto ao quê ensinar e ao quê pesquisar. Para o governo, a instituição universitária, incluindo-se os seus professores, deveria realizar um dado conjunto de atividades. Cada universidade, com exceção das consideradas de excelência, seria competente para ensinar ou pesquisar algo bastante específico à sua realidade e às condições de obtenção de êxito. Assim, aproveitar-se-ia, ao máximo, a força de trabalho acadêmica para eficiência (economia de recursos), eficácia (adequação do produto), e elevação da produtividade com alguma qualidade. Torna-se evidente, portanto, que o Executivo Federal, ao deflagrar a nova reforma, optou por um modelo de diversidade e de diferenciação institucional que tem por suposto a avaliação permanente e o autofinanciamento. Agrava ainda mais a situação o fato de que se realiza uma categorização dos produtos e serviços do trabalho acadêmico, que implica organizar o tempo-espaço acadêmico do mesmo modo que a empresa capitalista o faz para o atendimento dos seus diferentes clientes ou usuários.

A lógica e as ações, que presidem a desorganização da educação superior, ocorrem na direção de tornar o trabalho acadêmico mais produtivo

${ }^{24}$ Isso está posto na Reforma da Administração e da Previdência e, mais especificamente, no Decreto no 2.306/97, que estabelece as possibilidades de formatos institucionais quanto à natureza jurídica e à organização acadêmica. O decreto prevê a organização da educação 
do ponto de vista dos interesses prevalecentes no mercado. Essa racionalidade econômica revela que a universidade e o trabalho acadêmico só possuem relevância econômica e social quando formam profissionais aptos às necessidades atuais do mercado de trabalho e quando pesquisam, geram ou potencializam os conhecimentos, as técnicas e os instrumentos de produção e serviços que possibilitem a ampliação do capital $^{25}$.

$\mathrm{Na}$ prática, portanto, a reorganização da educação superior não é aparente, mas formal e real. É formal porque acontece (politica e legalmente) com base no formato existente e é real porque passa a subordinar, em grande parte, os elementos organizativos do tempo-espaço do trabalho acadêmico $^{26}$. Ao que parece, para o MEC é preciso reorganizar o sistema

superior sob a forma de universidades, centros universitários, faculdades integradas, faculdades e institutos superiores ou escolas superiores.

25 Segundo Cunha (1997), no entanto, a lógica que dá sustentação à reforma da educação superior atual não é recente. Após sumariar as propostas de reformulação do ensino superior, Cunha chega à conclusão de que se trata de uma lógica e de um modelo que vem sendo concebido e preparado desde os anos 80, com a criação do Grupo Executivo para a Reformulação da Educação Superior (Geres). Algumas proposições vêm ganhando força desde essa época, como: processos amplos de avaliação de desempenho; autonomia universitária; fontes alternativas de financiamento; interação com a comunidade; mudança nos mecanismos de acesso ao ensino superior; parceria com o setor produtivo; administração mais racional; racionalização dos gastos e aumento da produtividade; expansão do sistema.

26 A categoria tempo-espaço é amplamente considerada nos trabalhos de Harvey (1992) e de Santos (1997). Em seu estudo, Harvey (1992) evidencia a emergência de novas maneiras dominantes pelas quais experimentamos o tempo e o espaço. Ele examina "a experiência do tempo e do espaço como um vínculo mediador singularmente importante entre o dinamismo do desenvolvimento histórico geográfico do capitalismo e complexos processos de produção cultural e transformação ideológica" (p. 9). Ele mostra que no capitalismo "as práticas e processos materiais de reprodução social se encontram em permanente mudança". Por isso, "as qualidades objetivas como os significados do tempo e do espaço também se modificam" (p. 89). Para esse autor, vive-se uma fase de compressão do tempo-espaço decorrente, em grande parte, da transição do fordismo para a acumulação flexível. Essa transição ou aceleração generalizada, especialmente da produção, "foi feita em partes por meio da rápida implantação de novas formas organizacionais e novas tecnologias produtivas" (p. 257). Por sua vez, Santos mostra que a base técnica da sociedade e do espaço constitui, hoje, um dado fundamental da explicação histórica, já que a técnica invandiu todos os aspectos da vida humana (p. 67), impondo-se em uma perspectiva racionalizante e hostil à vida social. Com a aceleração contemporânea e a constituição do meio técnico-científico informacional, o que está em jogo é a mudança da relação homem-natureza, afirma Santos. A ordem vital, de quem a natureza é amiga, cede lugar a uma ordem racional (da tecnociência) à qual a natureza é hostil. A natureza una torna-se socialmente fragmentada, embora unificada em beneficio das firmas, Estados e classes hegemônicas (p. 19). É, assim, unificada segundo uma racionalidade mercantil. A técnica passa a ordenar os espaços, impor e modelar nossas 
federal para organizar a educação superior no país, o que significa que esse reordenamento é parte constitutiva da nova racionalização técnica e dessa nova visão economicista/produtivista. De um modo geral, diversifica-se e diferencia-se a oferta de educação superior para que esta possa se expandir e tornar-se mais ágil e dinâmica no atendimento e na produção de um saber interessado no sentido capitalista, levando, assim, as universidades a serem organizações mais produtivas e pragmáticas. Torna-se urgente, portanto, investigar as alterações que ocorrem na produção do trabalho e da vida acadêmica das universidades públicas, mormente em razão da maior presença do mercado e do Estado avaliador e gestor.

\section{Alterações na produção do trabalho e da vida acadêmica}

A análise desenvolvida até aqui ganha maior amplitude, à luz de elementos categoriais que possam se centrar na produção do trabalho e da vida acadêmica. Por isso, pretende-se, agora, identificar e problematizar a reforma atual da educação superior no Brasil com base em elementos da teoria do valor-trabalho que expressam, com mais evidência, as tensões e os conflitos presentes na reestruturação do sistema de educação superior e no cotidiano universitário ante às novas demandas do capital, às exigências e desafios da sociedade contemporânea e às políticas educacionais para esse nível de ensino.

A adoção de elementos da teoria do valor-trabalho, para uma análise do atual reordenamento da educação superior, justifica-se, por duas razões. A primeira, porque essa teoria explicita determinações fundamentais do modo de produção capitalista e as suas correspondentes relações de produção, de

relações. Impõe-se uma gestão técnica e racionalizadora e uma matematização do espaço e da vida social. Os objetos, as coisas e os sistemas técnicos passam a comandar as relações, pondo em discussão a questão da modernização tecnológica capitalista, sobretudo dos seus efeitos sobre a vida social e sobre o mundo do trabalho. 
circulação, de distribuição e de consumo. A educação superior tem um papel importante na composição da força de trabalho e na forma contemporânea de valorização e expansão do capital (Offe, 1994; Lojkine, 1995; Harvey, 1992; Rifkin, 1995; Chesnais, 1996). A segunda refere-se ao fato de que, ao examinar os ingredientes que compõem a reforma atual, verifica-se que elementos da teoria do valor-trabalho permitem evidenciar a natureza das políticas para a educação superior e a racionalidade subjacente a essa reforma, especialmente no que tange a uma maior subordinação do trabalho acadêmico ao mercado.

A preocupação com as interfaces das múltiplas determinações da produção do trabalho e do cotidiano acadêmico colocam questões, como: que categorias teóricas melhor expressam a realidade da produção acadêmica e as suas múltiplas determinações? Que formas essas categorias vem adquirindo historicamente? O que determina essas formas? O que significa analisar as diferentes formas de desenvolvimento da educação superior e estabelecer suas conexões internas, ou seja, compreender os elos de ligação dessa diversidade? Qual, então, o movimento real e contraditório a ser mostrado?

Supõe-se que as categorias que melhor explicitam a produção do trabalho e da vida acadêmica são aquelas que expressam vários tipos de relações de produção do trabalho acadêmico e da vida acadêmica. Essas categorias devem ser expressões teóricas, abstrações, das relações sociais de produção do trabalho acadêmico e da vida acadêmica (Rubin, 1987). Presume-se, ainda, que é possivel compreender e expor esse processo de ajuste das universidades públicas à nova lógica operacional/gerencialista (Chauí, 1998; Lima, 1997) e à nova racionalidade economicista/produtivista, valendo-se da investigação de aspectos significativos dessa constituição.

Novos conceitos, ou melhor, novas relações de produção do trabalho acadêmico surgem nas universidades públicas brasileiras, especialmente nas federais, em razão do processo de ajuste às demandas e exigências do 
mercado e à internacionalização produtiva do capitalismo atual. Levanta-se a hipótese de que esses novos conceitos e essas novas relações de produção do trabalho acadêmico tenham sua origem, em grande parte, no atual sistema de relações de produção capitalista. Desse modo, observa-se a idéia de que um conceito só surge de outro na presença de condições sócio-econômicas determinadas (Rubin, 1987: 106).

Analisa-se a nova reforma da educação superior com base na: problematização acerca das possibilidades e dos limites da subsunção formal e real do trabalho acadêmico ao capital, enfatizando o atual processo de subordinação da produção acadêmica das universidades federais; reflexão sobre o que seja o trabalho acadêmico produtivo e improdutivo na lógica propugnada pela reforma da educação superior, sobretudo quando se considera o processo e as relações de produção no âmbito da sociedade capitalista.

\subsection{A subsunção formal e real do trabalho acadêmico ao capital}

Para melhor compreender o crescente processo de subordinação do trabalho acadêmico ao capital, na atual reforma da educação superior, é preciso considerar, em primeiro lugar, como se realizam historicamente os processos de subsunção formal e real do trabalho ao capital.

O capitalismo, em sua fase inicial, assume formalmente o trabalho como ele estava ou como se encontrava. A subsunção formal significa, exatamente, subordinação do trabalho ao capital, sem mudanças no processo de trabalho 27 . O artesão, embora ainda domine o saber (por inteiro) do seu oficio, já não produz para si, mas para o capitalista, que é dono dos meios de produção, representando a forma social assumida pelo novo modo de produção, do qual se deriva a expressão subordinação formal. O trabalho encontra-se subordinado aos interesses do capitalista. Assim, o artesão é

27 A esse respeito, consultar Rubin (1987: 27-33); Paro (1996: 35-79). 
alienado do produto do seu trabalho. O capitalista é alguém que possui capital e passa a adquirir unidades de produção (oficinas de trabalho) onde cada proprietário/artesão produz privadamente. O trabalho do artesão é, então, subsumido pelo dono do capital que passa a buscar, cada vez mais, formas de produzir com eficiência, aumentar a produtividade e a sua competitividade no mercado. Por isso, o processo de produção passa a ser organizado em conseqüência do planejamento estabelecido pelo dono dos meios de produção.

O capitalismo não fica somente na subordinação formal do trabalho ao capital. O capitalista descobre que a divisão pormenorizada ou técnica do trabalho tem a vantagem de aumentar a produtividade e o lucro. Essa divisão inicia-se com o trabalho na manufatura. Para o trabalhador, por sua vez, essa divisão tem a desvantagem de submetê-lo, paulatinamente, à execução de tarefas parcelares e rotineiras, tornando-o uma peça na engrenagem de produção. O trabalhador passa a ter seus movimentos controlados e subordinados ao tempo-espaço da maquinaria (Marx, 1996: 558), ocorrendo, desse modo, uma subsunção real/concreta do trabalho ao capital (Paro, 1996: 53). Além da propriedade dos produtos do trabalho, o trabalhador priva-se, progressivamente, do saber sobre o processo de produção, tornando-se mais um instrumento do trabalho, perdendo assim, tecnicamente, a condição de sujeito. Por isso, com a subordinação real do trabalho ao capital, ocorre uma desqualificação do trabalhador.

O trabalhador individual torna-se parte do trabalhador coletivo por força do modo de organizar a produção. O capitalista descobre que a cooperação (junção de trabalhadores que executam tarefas parcelares, mas conexas) permite aumento da produção, além de diminuir os gastos com capital variável, ou seja, com a força de trabalho. A maquinaria, no processo de produção, contribui para desqualificar o trabalhador, à medida que simplifica as tarefas no processo de trabalho. Ocorre, por decorrência, uma separação entre concepção e execução. Assim, pode-se dizer que, na 
organização capitalista, o trabalho humano perde a unidade concepção/execução. O saber de concepção passa a ser dominado por aqueles que vão gerenciar o processo de produção. Esse gerenciamento, por sua vez, tem a finalidade de potencializar o trabalho $\mathrm{e}$ aumentar a produtividade por meio da racionalização do processo produtivo 28 .

A diferença entre subsunção formal e real do trabalho ao capital é fundamental para se compreender o grau possível de subordinação do trabalho acadêmico ao capital na atual reforma da educação superior. Para entender o grau de subordinação é, também, fundamental saber se as IES são públicas, ou seja, mantidas pelo Poder Público, ou privadas, sustentadas pela iniciativa privada.

A subsunção formal, no caso das instituições privadas, é bastante evidente. A produção acadêmica, nesse caso, é comandada e organizada por principios capitalistas que têm por finalidade última a obtenção da maisvalia. Do ponto de vista do capitalista, ou seja, do proprietário da IES privada, os produtos são vendidos e os serviços são prestados, objetivando o lucro. O planejamento do trabalho acadêmico ocorre, em geral, segundo os interesses do proprietário da instituição. Este, também, compra a força de trabalho acadêmica que passa a produzir conforme seus interesses. A subsunção real, por sua vez, é mais sutil. A força mobilizadora do proprietário de uma IES privada significa a busca de uma maior eficiência e de uma maior produtividade, em razão da competitividade no sistema. No entanto, por causa do trabalho complexo e qualificado que é exigido, há um limite para a subordinação do trabalho docente, ou seja, para a expropriação do saber e para o controle do trabalho acadêmico, especialmente no processo ensino-aprendizagem. Vale lembrar, como já foi evidenciado, que a organização do trabalho acadêmico é feita pelo capitalista, que racionaliza

28 Atualmente, o processo de gerenciamento também passa por modificações, como: o fim dos empregos, a redução do número de trabalhadores (Rifkin,1995), a tecnicização e terceirização do trabalho (Offe,1994; Lojkine,1995). Há, portanto, profundas alterações em relação à forma anterior. 
permanentemente a produção do trabalho acadêmico, potencializando e aumentando a produtividade, objetivando ampliar o seu lucro 29 .

No caso das IES mantidas pelo Poder Público, a questão da subsunção formal e real é certamente mais complexa, caso em que parece ser inadmissivel qualquer forma de subsunção, já que as IES públicas têm o Estado como mantenedor, consomem recursos do fundo público, organizamse, em geral, em direção ao interesse coletivo e, em princípio, não produzem mais-valia. No entanto, como se viu no tópico anterior, o empreendimento e a lógica presentes na atual reforma da educação superior são claramente colocados com o objetivo de ampliar a subordinação da gestão e do trabalho acadêmico ao mercado.

É preciso, contudo, evidenciar dois aspectos iniciais que estão induzindo concretamente o processo de subordinação das IES públicas e que complexificam a análise. Primeiro, as universidades públicas, especialmente as federais, em parte, em razão da necessidade de autofinanciamento, começam a assumir as feições das instituições privadas, sobretudo no que tange à venda de serviços e bens ${ }^{30}$. O Estado já não é o único mantenedor, o que pode vir a interferir nos princípios de direito público que regem a organização dessas instituições ${ }^{31}$. Segundo, o processo de produção nas universidades públicas, de médio e grande porte, inclui produtos materiais e

29 Paro (1996), no Capítulo IV do seu livro, com base em determinada concepção de educação e sob pena de descaracterizar-se o processo pedagógico, explicita porque é tão dificil ocorrer a subordinação real da atividade educativa escolar. Segundo o autor, $a$ especificidade do processo pedagógico escolar impossibilita a generalização do modo de produzir autenticamente capitalista na escola (p. 149). Essa questão será melhor explorada quando da análise do trabalho produtivo e improdutivo.

30 A evolução dos orçamentos das Ifes, nos últimos anos, demonstra exatamente o empreendimento do governo federal a fim de induzir essas instituições à ampliação da receita própria, mormente por meio de convênios e venda de serviços e bens acadêmicos, como é evidenciado no Capítulo III.

31 Para entender essa questão, é preciso considerar a ampla reforma do Estado que ocorre no Brasil, especialmente em direção à sua minimização, em razão da crise do padrão de financiamento público que configurava o Estado do bem-estar. Nessa reestruturação do Estado, verifica-se redução dos gastos públicos com a reprodução da força de trabalho, manutenção do fundo público como pressuposto, apenas, do capital e uma ampla subordinação do Estado aos interesses do capital (Oliveira, 1988). 
não-materiais, diferentemente da escola básica ${ }^{32}$. Em geral, os produtos materiais ou acadêmicos são produzidos por encomenda do capital produtivo, para atender às suas demandas, ou objetivando o mercado. No primeiro caso, o capital produtivo determina inteiramente o movimento do trabalho acadêmico, uma vez que este se engaja no processo de produção empregado pelo capital produtivo. O mesmo já vem ocorrendo, em grande parte, com os serviços que a universidade presta. Há um claro empreendimento para tornar bens e serviços mais úteis economicamente, além de permitir o aumento da receita própria das instituições públicas ${ }^{33}$.

É preciso considerar, ainda, que a universidade pública no Brasil tem papel importante na alteração do instrumental de trabalho, bem como nos métodos de produção. Ela desempenha papel preponderante na criação de tecnologias de produção e de organização do trabalho, que, por sua vez, possuem a condição de poupar trabalho e aumentar a produtividade e a taxa de mais-valia. Por essa razão, em grande parte, é vista como espaço privilegiado de intensificação da capacidade de competir, com êxito, na mundialização dos mercados de produção, de consumo e de trabalho.

Nessa lógica, o papel atribuído às IES públicas, especialmente às universidades federais, pressupõe maior plasticidade e flexibilidade dessas instituições, cujo ajustamento ocorre, como se viu anteriormente, por meio de um amplo processo de diversificação e flexibilização, implicando progressiva diferenciação da forma e conteúdo da educação superior, do que decorre o atendimento a clientes diferenciados e desiguais, do ponto de vista das relações de troca e do volume de capital que possuem. Cada cliente pode pleitear o produto/mercadoria de acordo com seus dons e aptidões naturais, especialmente no caso do ensino. Pode-se concluir, então, que a

\footnotetext{
${ }^{32}$ A produção acadêmica na universidade não se restringe apenas ao processo pedagógico propriamente dito. Por isso, a impossibilidade da generalização do modo de produzir autenticamente capitalista na produção acadêmica da universidade torna-se mais frágil.

33 Esses aspectos apontados permitem evidenciar clara intenção de ampliar os limites da subsunção formal e real das IES mantidas pelo Poder Público, provavelmente aproximandoas das feições das IES privadas.
} 
desigualdade dos clientes deve ter por correspondência uma desigualdade na oferta. Nem todos têm acesso a essa mercadoria e aqueles que a ela têm acesso o fazem em situação diferenciada e desigual de modo a preservar, em grande parte, a diferença e a desigualdade natural existente (Rousseau, 1989; Warde, 1984; Oliveira, 1994).

A produção acadêmica certamente tem um valor de uso. Ela, no entanto, é, cada vez mais, forçada a se tornar um valor de troca, o que significa dizer que o ajustamento da educação superior procura dar à pesquisa e ao ensino, cada vez mais, a forma de mercadoria, ou seja, o ensino e a pesquisa passam a ter valor de troca, circulando e concorrendo mais no mercado. A pesquisa e o ensino são, desse modo, submetidos, progressivamente, à lógica e aos principios capitalistas, o que vem intensificando as tensões e os conflitos no interior das IES públicas, uma vez que se alteram a natureza do trabalho acadêmico e as finalidades da instituição. O saber universitário torna-se, cada vez mais, uma mercadoria produzida conforme os interesses dos consumidores e, portanto, destinada a atender às necessidades e às demandas do mercado. Até mesmo a força de trabalho acadêmica é vendida ou comprada por determinado preço, aparecendo, cada vez mais, como uma mercadoria disponivel para troca. Assim, o mercado tende a regular os serviços e produtos do trabalho acadêmico e, por conseqüência, o trabalho acadêmico. Essa produção só passa a ter sentido como possibilidade concreta de ser trocada para consumo ou para uma nova troca, tomada, portanto, como uma mercadoria, uma coisa.

Essa lógica induz concretamente a produção acadêmica a se tornar uma mercadoria disponivel para troca. Parafraseando Marx (1996: 96), pode-se dizer que só através da troca se pode provar que essa forma de trabalho é útil aos outros, que seu produto satisfaz necessidades alheias, ou seja, de outros produtores privados. Esse processo social, no entanto, subjuga a produção a uma apropriação privada, submetendo-a a uma relação econômica imediata, 
movida por interesses privados, subvertendo, em larga medida, o valor do trabalho acadêmico nas universidades públicas, ampliando sua subordinação.

Essa lógica determina o que cada IES deve produzir para a troca, seja o ensino ou a pesquisa. Ensino e pesquisa com qualidades diferenciadas, atestadas/avaliadas e expostas aos compradores/consumidores. Esse intercâmbio ocorre com base em uma desigualdade explícita do ponto de vista da qualidade e das quantidades da mercadoria ofertada e da desigualdade econômica e cultural dos compradores, ou seja, dos alunos, no caso do ensino. Os compradores/consumidores adquirem a mercadoria que lhes é possivel obter ${ }^{34}$. Embora ela pareça equivalente a outras mercadorias semelhantes, já que não há distinção formal na hora do registro curricular profissional, as diferenças qualitativas do processo ensino-aprendizagem e de capital institucional são reais e definem o ingresso e o exercício da profissão no mercado de trabalho ${ }^{35}$. A mercadoria adquirida, que possui qualidade inferior, não permite ao seu proprietário (ao aluno) ingressar e/ou permanecer com eficiência no mundo do trabalho.

O capital, nessa lógica, expressa seu domínio sobre o trabalho e a produção acadêmica. O interesse do capital se dá em razão de que o valor do trabalho/produção acadêmica se expande por intermédio da troca, o que explica a importância do trabalho e da produção acadêmica, atualmente, para a expansão/autovalorização do capital. No entanto, a universidade é

\footnotetext{
34 Nessa lógica, a mercadoria não representa propriamente o ensino, mas a credencial. $\mathrm{O}$ ensino é reduzido a uma certificação, que habilita o seu portador ao exercício de uma profissão ou, pretensamente, aumenta a sua empregabilidade mediante um nivel maior de escolarização.

35 A política de diversificação e diferenciação da educação superior, especialmente por meio dos rankings do Exame Nacional de Cursos (ENC), o denominado Provão, acentua, ainda mais, o capital institucional, em particular das universidades. O Provão contribui para determinar esse capital, uma vez que amplia o grau de distinção das IES. No entanto, é preciso ter clareza que não é só a qualidade real do ensino adquirido que define o ingresso na profissão e a aquisição do emprego. Afinal, aprende-se com Bourdieu (1998: 72-79) que o capital cultural inclui, além do capital em seu estado institucionalizado, o capital em seu estado incorporado e objetivado.
} 
plenamente determinada por essa base material? Ela fatalmente pode ser subsumida pelo capital?

\subsection{O trabalho acadêmico produtivo e improdutivo}

Face ao exposto, seria quase dispensável definir trabalho acadêmico produtivo e improdutivo no âmbito da produção acadêmica. No entanto, a discussão dessas categorias permite aprofundar o entendimento da lógica de reestruturação da educação superior. Inicialmente, é preciso ter claro algumas noções de fundo histórico, uma vez que o trabalho acadêmico produtivo e improdutivo estão profundamente ligados ao processo de produção, às relações de produção e, portanto, ao processo de exploração do trabalho pelo capital na sociedade capitalista.

O processo de exploração no modo de produção capitalista tem algo de singular: a invenção da mais-valia. A análise da teoria do valor, em Marx, evidencia que a força de trabalho é a única mercadoria capaz de produzir valor. A força de trabalho possui a propriedade de criar mais valor do que ela própria tem. Ao trabalhar para compor a força de trabalho, por meio da produção de valores de uso, gasta-se força de trabalho, sendo exatamente o que leva o homem a produzir mais que o necessário para sobreviver. Assim, como qualquer outra mercadoria, a força de trabalho possui valor de uso e valor de troca, o que significa que ela pode ser comprada e consumida. Ela é livremente vendida (no mercado) pelo possuidor de força de trabalho (proprietário livre da capacidade de trabalho) e comprada, por um salário, pelo proprietário de capital $^{36}$. Nesse processo de consumo da força de trabalho pelo capitalista, ocorrem dois fenômenos: a) o trabalhador trabalha

\footnotetext{
36 Essa compreensão da força de trabalho como mercadoria especial, que, ao ser consumida cria valor, é explicitada por Marx, especialmente, no Capítulo I de O Capital (Marx, 1996: 4193).
} 
sob o controle do capitalista, a quem pertence seu trabalho; b) o produto é apropriado pelo capitalista.

O processo de exploração do trabalho, ou seja, a mais-valia no capitalismo, consiste, então, na apropriação, pelo capitalista, do valor produzido pelo trabalhador para além do tempo de trabalho necessário à sua subsistência ${ }^{37}$, ou seja, o trabalhador continua a trabalhar para além do trabalho necessário. As horas de trabalho excedentes não são pagas pelo capitalista, que se apropria desse valor (Marx, 1996: 46-47). A mais-valia produzida, por sua vez, expressa-se de duas formas - como mais-valia absoluta ou como mais-valia relativa. No primeiro caso, ela se dá pela extensão ou pela intensificação do trabalho para além dos limites do trabalho necessário. No segundo caso, a apropriação ocorre quando há um aumento da produtividade em razão da incorporação de novas tecnologias e/ou novas formas de organizar a produção (Marx, 1996: 363).

A mais-valia relativa ${ }^{38}$ varia, portanto, em razão direta da produtividade do trabalho. Ela se eleva, ou cai com a ascensão ou queda da produtividade do trabalho (Marx, 1996: 367). O aumento da produção, em razão das novas tecnologias, provoca queda do preço da força de trabalho, bem como das mercadorias. Na prática, portanto, a tecnologia poupa trabalho e leva o valor a se incorporar em uma maior quantidade de produtos. Ao mesmo tempo, a concorrência no mercado atua como força mobilizadora que leva o capitalista a querer produzir mais barato. Por isso, o capitalista procura intensificar o trabalho ou mudar a tecnologia, a fim de

37 É interessante observar como Marx explica a determinação da força de trabalho. Ela é determinada pelo tempo de trabalho necessário à sua produção e, por conseqüência, à sua reprodução. Assim, ele afirma: "o limite último ou mínimo do valor da força de trabalho é determinado pelo valor da quantidade diária de mercadorias indispensáveis para que o portador da força de trabalho possa continuar vivendo". (Marx, 1996: 193).

38 Paro (1996: 47) explica a mais-valia relativa do seguinte modo: "Essa elevação da produtividade implica o aumento relativo do tempo de trabalho excedente, mas pela redução do tempo de trabalho necessário. Essa mudança quantitativa entre trabalho necessário e trabalho excedente, sem que se promova o prolongamento da jornada de trabalho, nem a intensificação deste, só pode ser alcançada pela mudança do processo de trabalho. A mais- 
diminuir o tempo de trabalho necessário. Assim, quase sempre, o aumento da tecnologia faz crescer a mais-valia, razão por que o capitalista aproveitase, então, da tecnologia para aumentar a mais-valia.

Compreender como se produz a mais-valia é fundamental para entender o trabalho produtivo e improdutivo em Marx. Para este, do ponto de vista do processo de produção capitalista, só é produtivo o trabalho que produz mais-valia para o dono dos meios de produção, ou seja, seu trabalho serve à expansão/autovalorização do capital (Marx, 1996: 584). Assim,

a determinação do trabalho produtivo (e por conseguinte, também, a do improdutivo, como seu contrário) funda-se, pois, no fato de que a produção do capital é produção de mais-valia, e em que o trabalho empregado por aquela é trabalho produtor de mais-valia. (Marx, 1978: 80)

Trabalho produtivo, então, é aquele trabalho assalariado comprado pelo capitalista, como capital variável, objetivando extrair mais-valia, do que decorre que o trabalho produtivo é aquele explorado e subordinado em geral ao processo de produção e valorização do capital.

Assim, só é produtivo o trabalho organizado sob a forma de processo capitalista de produção (Rubin, 1987). Ou seja, trabalho produtivo é aquele organizado sob a forma de princípios capitalistas, sendo empregado pelo capital produtivo em fase de produção e de circulação. Nesse sentido, as relações sociais de produção, sob as quais o trabalho é organizado e realizado, determinam se o trabalho é produtivo. Dessa forma, o conteúdo, o caráter e os resultados úteis do trabalho não definem se ele é produtivo, já que essa noção diz respeito ao trabalho produtivo em geral, ou seja, ao processo entre o homem e a natureza e não é adequada ao processo de produção capitalista.

valia decorrente dessa redução do tempo de trabalho necessário é chamada de mais-valia relativa". 
Compreendendo trabalho produtivo como aquele que produz maisvalia, Marx diz existir duas possibilidades, quando se trata da produção nãomaterial:

1) O resultado são mercadorias que existem isoladamente em relação ao produtor, ou seja, que podem circular como mercadorias no intervalo entre a produção e o consumo; por exemplo: livros, quadros, todos os produtos artísticos que se diferenciam da atividade artística do artista executante. A produção capitalista só se aplica aqui em forma muito limitada. Essas pessoas, sempre que não contratem oficiais etc., na qualidade de escultores etc., comumente (salvo se forem autônomos) trabalham para um capital comercial, como, por exemplo, livreiros, uma relação que constitui apenas uma forma de transição para o modo de produção apenas formalmente capitalista. Que nessas formas de transição a exploração do trabalho alcance um grau superlativo, não altera a essência do problema.

2) O produto não é separável do ato de produção. Aqui, também, o modo capitalista de produção só tem lugar de maneira limitada, e pela própria natureza da coisa, não se dá senão em algumas esferas. (Necessito do médico, não de seu moleque de recados). Nas instituições de ensino, por exemplo, os docentes podem ser meros assalariados para o empresário da fábrica de conhecimentos. Não se deve considerar o mesmo para o conjunto da produção capitalista. (1978: 79, grifos meus)

As duas possibilidades da produção não-material são fundamentais para a análise do trabalho acadêmico. Várias características apontadas por Marx aplicam-se a essa forma de produção, em que a produção pode resultar em produtos/mercadorias (livros, produtos culturais, artísticos, científicos e tecnológicos etc), como também na não-separação do produto do ato de produção. No primeiro caso, amplia-se atualmente a subordinação formal e, até real, da produção do trabalho acadêmico, nas IES públicas, ao capital produtivo. No segundo caso, a subordinação só tem lugar de maneira limitada, uma vez que, pela própria natureza do trabalho acadêmico, ela só pode ocorrer de modo periférico. Segundo Paro (1996: 148), a especificidade ou a natureza do trabalho educativo significa que o produto permanece para além do ato de produção, e ocorre porque,

como característica de toda educação, a apropriação do saber historicamente acumulado só se dá, na escola, a partir de uma relação na qual o aluno entra não apenas como objeto mas também como sujeito da educação. Enquanto sujeito, ele participa ativamente do processo, tornando-se co-produtor da atividade pedagógica. Enquanto objeto, ele 
entra, por um lado, na condição de beneficiário, ou seja, de consumidor, o que implica que num primeiro momento, o consumo do produto escolar se dê simultaneamente à sua produção; mas, também enquanto objeto de educação, o aluno entra, por outro lado, na condição de objeto de trabalho, no sentido de que ele se transforma, no processo, resultando num produto que permanece para além do ato de produção, o que significa que o consumo não se restringe à atividade produtiva, mas se prolonga para além dela. A presença do aluno enquanto objeto e sujeito da educação supõe necessariamente a existência do saber, que é o que dá substância e conteúdo à própria relação educador-educando. Este saber, enquanto matéria-prima do processo, não pode ser alienado do ato de produção, o que exige que o próprio educador, enquanto trabalhador, não seja expropriado do saber que ele precisa deter para 'passar' ao educando no processo de produção pedagógico.

Nesse sentido, Paro conclui que a natureza do processo de produção escolar, ou melhor, a especificidade do trabalho pedagógico impossibilita a generalização do modo de produzir capitalista. Para o autor (1996: 149),

\begin{abstract}
a escola se pauta por relações que dizem respeito à forma pela qual os homens tomam consciência da própria realidade concreta, descaracterizando-se, portanto, toda vez que ela deixa de fundar-se nessas relações para pautar-se por relações próprias do nível econômico da sociedade.
\end{abstract}

$\mathrm{Na}$ prática, como se vê, nas duas possibilidades apontadas para a produção não-material, a forma capitalista de produção só se aplica de forma muito limitada. No caso da universidade, no entanto, a possibilidade de o trabalho acadêmico produzir mercadorias e vender serviços, deixa-a mais vulnerável às demandas do capital produtivo e do mercado, o que amplia o risco de suas relações pautarem-se por relações próprias do nivel econômico da sociedade.

Uma outra forma de subsunção formal, tornando as IES públicas e o trabalho acadêmico mais produtivos, é a privatização, elemento presente na lógica da atual reforma da educação superior (Silva Jr. e Sguissardi, 1999). Nessa fase intermediária, o sistema de educação superior orienta-se na direção das fontes alternativas de financiamento, ou melhor, do autofinanciamento. 
Do mesmo modo que se pretende uma maior subsunção formal e real das IES públicas, há, por conseqüência, todo um empreendimento para tornar o trabalho acadêmico mais produtivo do ponto de vista capitalista, evidenciado no crescente interesse por essa produção. Ao que parece, portanto, o norte da reforma da educação superior é: tornar a universidade e o trabalho acadêmico mais funcionais $\mathrm{e}$ produtivos ao capital $\mathrm{e}$ ao capitalismo. Nessa lógica, a relevância econômica do trabalho acadêmico e da universidade parece residir, em grande parte, na potencialização das forças produtivas, especialmente porque permite maior transferência de valor aos produtos por meio do trabalho mais qualificado.

É preciso considerar, ainda, um outro elemento dessa problemática nas IES públicas o trabalho é assalariado, assim como em toda sociedade capitalista. No entanto, ainda não se trata de um salário comprado pelo capital variável, já que o Poder Público, com recursos do fundo público, paga os salários dos docentes. E, como diz Marx (1978: 72), só é produtivo o trabalho assalariado que produz mais-valia. Precisamente, por isso, o trabalho acadêmico estatal não se subordina formalmente ao capital ${ }^{39}$.

A universidade pública não funciona como uma empresa, norteada pelos princípios capitalistas de produção. Em geral, o trabalho acadêmico, em uma universidade pública, orienta-se e organiza-se por princípios de direito público e não sob a forma de empresas capitalistas privadas, razão pela qual seu trabalho é improdutivo, do ponto de vista capitalista, mesmo ocorrendo nessa formação social.

De qualquer modo, a reforma atual impõe à universidade maior produtividade do trabalho acadêmico, bem como a adoção de uma nova racionalidade econômica. De que maneira, no entanto, a necessidade de

39 É preciso lembrar, no entanto, que atualmente, ante os baixos salários nas Ifes, os docentes buscam formas de complementação salarial, o que pode estar subordinando, em parte, sua produção. 
maior produtividade do trabalho exige maior produtividade das universidades? Marx (1996: 47) afirma que

a produtividade de trabalho é determinada pelas mais diversas
circunstâncias, entre elas a destreza média dos trabalhadores, o grau de
desenvolvimento da ciência e sua aplicação tecnológica, a organização
social do processo de produção, o volume e a eficácia dos meios de
produção, e as condições naturais.

Embora Marx refira-se à produtividade do trabalho concreto, ou seja, àquele que produz valores de uso, que não se confunde com o ponto de vista capitalista, observa-se que a produtividade do trabalho é determinada, em grande parte, por atribuições modernas de uma universidade no contexto da sociedade capitalista atual. Como exemplo, podem ser citadas, algumas das exigências contemporâneas, do ponto de vista capitalista: a) formar profissionais com habilidades cognitivas e competências sociais necessárias ao mundo do trabalho; b) desenvolver ciência e tecnologias úteis à produção; c) desenvolver técnicas de organização do processo de produção e de prestação de serviços (gestão empresarial, tornando mais eficaz a produção e a oferta de serviços) ${ }^{40}$. A universidade teria, assim, o preponderante papel de qualificar ou potencializar a força de trabalho e os meios e as técnicas de produção. Não se pode esquecer que o aumento da produtividade "exige alteração no instrumental ou no método de trabalho ou em ambos ao mesmo tempo" (Marx, 1996: 362).

A questão da produtividade esclarece bastante as demandas e o processo de ajustamento das universidades brasileiras, mormente das federais. Demanda-se às universidades a produção de conhecimentos úteis à produtividade das empresas, de modo a aumentar a sua eficiência e a sua

\footnotetext{
$40 \mathrm{Na}$ lógica das exigências capitalistas contemporâneas, a universidade e o trabalho acadêmico contribuem para a existência e desenvolvimento do capitalismo por intermédio do trabalho produtivo (produtor de mais-valia) mas, também, por meio da funcionalidade que adquirem em relação ao capital.
} 
competitividade ${ }^{41}$, porque a força motriz do processo de produção atual se localiza, sobretudo, na ciência e na tecnologia, bem como no trabalho flexive142. O aumento da produtividade do trabalho, nessas condições, permite a diminuição da quantidade de trabalho abstrato (criador de valor) e, em geral, reduz o valor dos produtos e dos serviços (Rubin, 1987: 82).

\section{A sociedade e o campo universitário: a universidade pública em questão}

Várias forças atuam interna e externamente para que as universidades públicas, especialmente as federais, modifiquem seu modo de ser e de agir, o que significa dizer, em outras palavras, que o campo 43 universitário, além das disputas naturais, representa atualmente um campo em estado de tensão e em processo de ebulição, diante das múltiplas determinações e conflitos presentes na reestruturação da educação superior. As forças dominantes, ao que parece, indicam que essas mudanças poderão alterar radicalmente a

41 Essa questão está evidenciada no documento: Uma politica para o ensino superior brasileiro: subsidios para discussão (Brasil. MEC, 1996) e nos textos de Durham (1998a, b e c). Essas demandas suscitam duas questões fundamentais para investigação. A primeira diz respeito à possivel separação entre universidade de ensino e universidade de pesquisa. A segunda refere-se ao fato de que a vinculação mais estreita ao mercado nem sempre se faz às custas de um avanço científico e sim, mediante uma aplicação pura e simples de tecnologias existentes.

42 A atual composição da força de trabalho parece exigir, cada vez mais, conhecimentos flexiveis. O saber-fazer amplia-se e ganha novo significado no atual estágio das forças produtivas do capitalismo. Os conhecimentos e as técnicas de produção e de prestação de serviços modificam-se, diferenciam-se, diversificam-se e renovam-se permanentemente. $O$ trabalho torna-se mais flexível e, na visão de Lojkine (1995), pode vir a ser, também, mais complexo e qualificado, especialmente para um pequeno grupo de trabalhadores do conhecimento, como afirma Rifkin (1995).

43 Campo, aqui, é entendido como espaço de luta, ou seja, locus no qual ocorrem relações de força e monopólios, lutas e estratégias, interesses e lucros (Bourdieu, apud Ortiz, 1983: 122) em que se trava uma luta concorrencial entre os atores em torno de interesses específicos que caracterizam a área em questão e no qual as posições dos agentes se encontram, $a$ priori, fixadas. 
natureza, o caráter, os valores e as finalidades das universidades públicas, sobretudo das Ifes ${ }^{44}$.

O movimento histórico, social e acadêmico de construção e reconstrução da universidade pública significa um fenômeno complexo porque se dá em um campo especial, o campo científico-universitário. Tratase de um campo provido de capital intelectual e cultural, que se interconecta com outros campos sociais, e que pode, ao mesmo tempo, expressar processos de reprodução e de transformação, de ajuste e de resistência, bem como de superação dos atuais conflitos e dilemas, por meio da inovação e da luta pela liberdade acadêmica e pela autonomia universitária.

\title{
3.1 Reprodução e transformação no campo universitário
}

O campo universitário, embora apresente especificidades que marcam sua luta concorrencial, intersecta, interage e, por vezes, está contido em outros campos mais amplos e mais determinantes da vida social, especialmente no âmbito econômico, político, cultural e do poder. Segundo Bourdieu (1996: 88), o campo científico

\begin{abstract}
é tanto um universo social como os outros, onde se trata como alhures, de poder, de capital, de relações de força, de lutas para preservar ou transformar essas relações de força, de estratégias de manutenção ou de subversão, de interesse etc., quanto é um mundo à parte, dotado de suas leis próprias de funcionamento, que fazem com que não seja nenhum dos traços designados pelos conceitos utilizados para descrevê-lo o que lhe dá uma forma específica, irredutivel a qualquer outra.
\end{abstract}

A atividade científica significa, portanto, uma atividade social e a construção é uma construção social da realidade (1996: 87). Como mundo à parte, o campo científico-universitário representa um espaço de luta

\footnotetext{
${ }^{44}$ No entanto, nossa hipótese é que essa percepção geral pode, em grande parte, ser negada concretamente pelas contradições e possibilidades de ação e reação das universidades públicas, no bojo da reforma da educação superior, em especial quando lutam
} 
permanente pela dominação, pelo monopólio da competência e autoridade cientifica, bem como pela legitimidade da ciência, em que as práticas, em sua maioria, caracterizam-se por esse estado de disputa permanente ${ }^{45}$.

O sentido do jogo, especialmente para os dominantes do campo, expressa-se por meio dos julgamentos, das escolhas e das práticas acadêmicas interessadas na manutenção/conservação das estruturas existentes de acumulação de prestígio simbólico, vantagens materiais e/ou formas particulares de poder. As estratégias científicas são, assim, motivadas pelo interesse consciente ou inconsciente de lucro material e/ou simbólico (Bourdieu, 1998: 36). Com efeito, os dominados no campo, como agentes sociais em combate e com suas práticas, podem desafiar os dominantes que, com suas competências técnicas e poder social, agem com autoridade, uma espécie de capital, um habitus científico que pode ser acumulado, transmitido e até removido para outros campos ou espécies. Essa disputa produz, para Bourdieu, um jogo e seu sentido; são posições posturais, quase sem necessidade de raciocinar para fazer uma jogada racional no jogo, no espaço social, no campo - em pleno funcionamento - em movimento. Esse modus operandi da ciência ou habitus científico permeia as relações no campo e alimenta as estratégias utilizadas.

O processo de acumulação do capital científico leva os produtores, nesse campo, a buscarem o reconhecimento ou a imposição do valor de seus produtos, bem como desacreditar/vulgarizar produtos e produtores concorrentes. A luta para adquirir uma posição dominante concretiza-se, muitas vezes, mediante ocupação de cargos, participação em comissões, busca de verbas, poder político de decisão, prêmios de reconhecimento, realização de consultorias etc. Acumular capital científico, portanto,

cotidianamente para fundar sua natureza e identidade em princípios, valores, regras e formas inerentes, historicamente, ao ideal de universidade.

${ }^{45}$ Segundo Miceli (1974), as práticas resultam de uma relação dialética entre uma estrutura

- por meio do habitus (modus operandi) - e uma conjuntura (condições de atualização do habitus). 
representa a forma básica de adquirir essa espécie particular de capital tão importante no campo: a autoridade científica, ou melhor, a capacidade e a competência cientifica para falar e agir legitimamente.

Os conflitos no campo universitário são, por outra parte, políticos/ideológicos. O interesse e a satisfação intrínsecos não se distinguem do interesse e da satisfação extrínseca (Bourdieu, 1983: 125), o que significa dizer, também, que o mercado dos bens e trocas acadêmicas é um universo social de poder, de capital, de relações de força, de lutas para preservar ou transformar essas relações de força, de estratégias de manutenção ou de subversão e de interesse que se vincula às estruturas objetivas dos diferentes campos sociais, bem como às estruturas incorporadas do habitus. A interrelação do campo universitário com os diferentes campos sociais parece implicar permanente processo de construção e reconstrução do espaço social e simbólico interno e externo ao campo. Em outras palavras, a estrutura do campo cientifico se define, a cada momento, pelo estado das relações de força entre os protagonistas em luta (Bourdieu, 1983: 133).

$\mathrm{Na}$ atual reforma da educação superior no Brasil, os protagonistas ou as forças dominantes que definem, em grande parte, a estrutura do campo parecem ser, no momento, externas ao campo ${ }^{46}$. Essas forças, no entanto, só conseguem atingir seus objetivos porque o campo universitário constitui um dos espaços de luta, de relações de força, de estratégias, de interesses, de contradições etc. As novas estratégias e valores que são, em grande medida, impostos e disseminados no campo só conseguem obter êxito porque encontram ressonância na academia. Os interesses $\mathrm{e}$ as estratégias concorrenciais no campo das universidades federais, antes minimizados e

46 O campo científico, como campo intelectual, por maior que seja sua autonomia, é determinado em sua estrutura e em sua função pela posição que ocupa no interior do campo do poder (Bourdieu, 1974: 190). Também os interesses dos compradores da força de trabalho, os que dominam o campo da produção econômica, procuram reduzir a autonomia do sistema de ensino, ampliando sua dependência direta da economia (Bourdieu, 1998: 1301). O campo universitário é, atualmente, uma parte do sistema de ensino que sofre intensamente o processo de subordinação ao sistema econômico. 
dissimulados, em razão do estado de cooperação ${ }^{47}$, das finalidades e da própria natureza dessas instituições, parecem explicitar, cada vez mais, propensão para investir abertamente, em franca disputa. O investimento de cada universidade já ocorre segundo sua trajetória, posição, ambição cientifica, capital de reconhecimento, chances objetivas de lucro. A alta produtividade torna-se fundamental para aumentar o reconhecimento, a consagração e para traçar novas estratégias de investimento. A nova disposição ou a atualização de certa cultura institucional, que toma forma no campo das universidades federais, poderá contribuir para o processo de diversificação e diferenciação (preconizado na reforma da educação superior).

O ideal de igualdade, de cooperação e solidariedade, sobretudo entre as universidades federais ${ }^{48}$, na ordenação institucional e na busca de maior homogeneidade, em termos de um padrão unitário de qualidade, dá lugar à competição e à busca de ganhos simbólicos e/ou materiais de agentes desigualmente dotados de capital, o que enfraquece as estratégias gerais de autonomia e/ou conservação do ideário existente no campo. As instituições com maior capital acumulado - intelectual, científico, político e social, tendem a assumir posição dominante (centros de excelência), enquanto as instituições dominadas ou pretendentes adotam estratégias de sobrevivência e de alteração de sua condição. De um modo geral, mesmo sem intenção deliberada e explícita, dominantes e dominados no campo universitário, especialmente nas Ifes, poderão, cada vez mais, se submeter à lógica hegemônica, à sociedade de mercado, à lógica e ao projeto de reestruturação da educação superior. O campo é levado, pelas políticas públicas atuais, que

\footnotetext{
${ }^{47}$ Esse estado de cooperação explica-se com base em certas condições históricas, que inclui, provavelmente, a convergência para um projeto nacional-desenvolvimentista, a imposição de um modelo sob o governo militar, o repúdio à ditadura, a luta pela democracia e pela construção da unidade do sistema federal de educação superior.

48 Parece evidente que esses ideais nunca foram consensuais, mas, por algum motivo, alimentavam a existência de um sistema que, em seu interior, comportava concepções distintas e contraditórias. Os rumos econômicos - e as opções políticas dos governantes, com certo apoio social e acadêmico - têm desequilibrado as relações de força em favor de uma tendência mais concorrencial e de "adaptação das universidades às mudanças contínuas e inesperadas" (Chauí, 1998).
} 
não se desvinculam de sua própria natureza, como espaço de luta pela autoridade científica e pelo poder, a subordinar-se a uma determinada lógica externa, perdendo paulatinamente a autonomia para se autodefinir.

O condicionamento do campo universitário implica maior comprometimento com a sociedade de mercado, com o campo da produção econômica, e, por isso, tende sempre à sua reprodução, deixando em segundo plano a inovação, a ruptura e a transformação social. O campo universitário parece tornar-se mais conservador, uma vez que instaura uma certa cultura organizacional que naturaliza, eterniza, consagra e legitima a ordem vigente, tornando mais dificil sua articulação com a ruptura, com a crítica, com a contralegitimidade e com a mudança social, o que ocorre porque a sobrevivência do campo universitário público e do mercado dos bens científicos depende, cada vez mais, da ordem econômica capitalista, em razão da progressiva diminuição dos fundos públicos.

A atual reforma da educação superior está conseguindo, assim, desestruturar certas práticas de solidariedade até então predominantes nas universidades federais, organizativas do sistema federal, com base em mecanismos que suscitam novas culturas e novos valores. Nesse sentido, a reforma instaura um processo de reorganização do sistema e de desestruturação do modus operandi, articulando-o a uma perspectiva de desenvolvimento social que não altera, na essência, o ciclo de reprodução social. Parece ser uma lógica inerente do campo reproduzir a si mesmo e a estrutura social, em que pese seu grau de autonomia em relação à sociedade global. Todavia, segundo Ortiz (1983: 28-29), o processo de reprodução se encontra relativizado pelo caminhar da História. As relações entre campo e sociedade global não se reduzem, necessariamente, à reprodução das condições objetivas. Muitas vezes, determinadas práticas transgressoras ou inovadoras podem associar-se ao movimento histórico e soldar-se 
organicamente à transformação da ordem vigente, fazendo com que a reprodução ceda lugar à transformação ${ }^{49}$.

\subsection{Ajuste, resistência e inovação no campo universitário}

A universidade é uma instituição científica, educativa e social singular, que tem servido historicamente a propósitos de reprodução do poder e das estruturas existentes, bem como à sua transformação. Historicamente, resistiu ou foi conivente com a ordem estabelecida, foi funcional ou idealista, interessada ou desinteressada, conservadora ou transformadora, passiva ou crítica, acomodada ou inovadora. É claro que, nem sempre, esses empreendimentos ou posições são tão evidentes no campo universitário. Há avanços e recuos, às vezes em um mesmo momento histórico, que ocorrem, provavelmente, porque o predomínio de um dos termos da contradição acima apontados não implica a eliminação do outro.

A universidade é uma instituição que faz parte, cada vez mais, da estrutura de poder social. Nessa estrutura, em cada tempo-espaço, ela se produz. Essa produção, na modernidade, é marcada por estratégias de conservação ou de subversão da ordem ou da realidade social. Valendo-se do modelo napoleônico e humboldtiano, a universidade ampliou seu relacionamento com a sociedade, com o Estado e com o mercado, ora para acentuar a reprodução no campo social, ora para formular ou vincular-se a projetos de transformação social. Vivenciando esse dilema, muitas vezes, acaba comprometendo ou negando sua própria existência.

Contraditoriamente, a afirmação da universidade está ligada a processos e momentos de reprodução e de transformação. Estudar a constituição da universidade, na modernidade, significa desvendar os mecanismos de poder que a circudam. Muitas vezes, ela foi dependente do

\footnotetext{
49 Segundo Ortiz, Bourdieu considera que, para romper o ciclo reprodutivista, é necessário, ao menos, conhecer os mecanismos de dominação que leva à reprodução (Ortiz, 1983).
} 
poder central ou parte do projeto de manutenção desse poder, como no caso napoleônico, em cujo modelo, perdeu sua autonomia, ganhou uniformidade e subordinou-se aos interesses do Estado autoritário.

Além das marcas do modelo napoleônico, a universidade conserva, ainda hoje, traços importantes dos períodos e espaços que contribuíram mais significativamente para sua constituição. As diferentes concepções de universidade existentes retratam essa realidade (Dreze e Debelle, 1983). Dentre os aspectos mais importantes, ela já foi considerada centro do saber geral, da totalidade dos conhecimentos e da formação enciclopédica; centro intelectual de formação das elites e da comunidade de pesquisadores de alta qualidade; locus privilegiado para a formação de profissionais e para a articulação ensino-pesquisa; centro de progresso e desenvolvimento econômico-social; instituição de formação das massas; instância importante na produção tecnológica e na ampliação da competitividade empresarial; organização fundamental na produção do novo conhecimento e nos processos de inovação tecnológica.

Os aspectos ou traços históricos marcantes das universidades decorrem das transformações sociais e das diferentes reformas de educação superior. Em cada tempo-espaço, surgem problemas que desafiam a capacidade de atualização e mesmo de sobrevivência das universidades. Essas condições objetivas suscitam processos de adaptação/ajuste, de resistência, de inovação e de mudança dessas instituições, o que acaba acrescentando ou redefinindo suas finalidades, seus valores e seu modo de agir.

De um modo geral, no entanto, o Estado e a sociedade de mercado, na modernidade, sempre exigiram maior adaptação da universidade pública quanto ao jogo social e à integração no processo produtivo, uma vez que a universidade nasceu na Idade Média como instituição independente e muito pouco permeável ao mundo extrauniversitário. Mais presentemente, as novas tecnologias da informação e da comunicação, a globalização e a competição 
produtiva colocam-se como fatores determinantes do ajuste da universidade (Carnoy, 1999). Ela é considerada historicamente lenta no processo de adaptação, especialmente em relação às mudanças no mundo do trabalho e às exigências do mercado.

Atualmente, entende-se com base nas exigências dos organismos multilaterais (Banco Mundial, Unesco), nas politicas de educação superior e nos principais agentes reformadores, no Brasil, que a pluralidade da sociedade contemporânea, as múltiplas solicitações, bem como as demandas sociais e culturais determinam maior permeabilidade e acomodação da universidade pública ao mundo não-universitário. A diversificação e a flexibilização apresentam-se como pré-condições para maior eficácia, dinamismo, maleabilidade e adaptabilidade dessas instituições. No centro dessa mudança e dessa disputa, no caso brasileiro, encontra-se a universidade pública, em que se realizam $90 \%$ da pesquisa no país (Trindade, 1999a) e na qual se concentra a quase totalidade dos programas de pós-graduação stricto sensu.

No caso brasileiro, atualmente, observa-se que os processos de ajuste prevalecem sobre os de resistência do campo universitário, sobretudo das universidades federais, o que ocorre, em grande parte, em razão do deliberado processo de desmonte do modelo único e porque há certo consenso quanto à necessidade de mudança nos fundamentos e na identidade das Ifes, diante das novas demandas, exigências e desafios contemporâneos. Em que pese a crise instalada, há certa concordância no campo das universidades federais quanto à necessidade de estabelecer maiores vínculos com a sociedade, especialmente com o contexto de desenvolvimento local e regional, em que cada instituição se insere ${ }^{50}$. Além disso, reconhece-se a importância da universidade na produção de conhecimento básico, na formação de

\footnotetext{
50 Esse argumento, muitas vezes, é usado para justificar a flexibilização, ou melhor, a adaptação, leia-se, eliminação de um sistema nacional que, pretensamente, não é compativel com o atendimento das necessidades locais/regionais.
} 
profissionais altamente qualificados, na resolução de problemas e na inovação tecnológica (Carnoy, 1999).

Essa concordância deve-se, em grande parte, à necessidade de ampliar a legitimidade institucional e, contraditoriamente, ao reconhecimento de que a universidade já não representa a única fonte do saber científico e, também, único locus da formação profissional, pelo menos nos moldes requeridos atualmente. A revolução dos meios e das formas de comunicação, bem como a crise atual da universidade, têm suscitado, igualmente, a questão da existência de um mundo sem universidade (Casper, 1997). Considera-se que as novas tecnologias da informação e da comunicação ampliam, cada vez mais, a circulação do conhecimento, bem como dispersam sua produção e aquisição, influenciando o futuro da universidade, obrigando-a a repensar suas funções e reinventar-se, o que denota os desafios, as tensões e a crise de legitimidade e de identidade que se instalaram e, ao mesmo tempo, mobilizam e movimentam as universidades públicas a fim de alcançar maior afirmação e maior relevância social.

No Brasil, esses processos de ajuste e, ao mesmo tempo, de resistência e de inovação das universidades públicas podem ser melhor visualizados valendo-se das mudanças introduzidas, notadamente em relação aos princípios clássicos de constituição da universidade na modernidade. A universidade voltada para a pesquisa, bem como o princípio da indissociabilidade ensino-pesquisa, segundo o ideal humboldtiano ${ }^{51}$, já não prevalecem no campo universitário. Além da unidade entre pesquisa e ensino não ser auto-evidente em boa parte das universidades, a reforma de educação superior no Brasil, empreendida pelo governo Fernando Herinque

\footnotetext{
51 Estamos nos referindo, sobretudo, aos princípios fundamentais para organização da universidade idealizados por Wilhelm von Humboldt (1767-1835) e que influenciaram a estruturação da Universidade de Berlim, na Alemanha. Dentre esses princípios estavam: a unidade entre pesquisa e ensino; a busca científica como infinita; a autonomia da ciência; a relação autônoma, porém integrada, entre Estado e universidade; a interdisplinaridade; a cooperação entre professores e entre professores e alunos.
} 
Cardoso, trabalha o ideário da diversidade de concepções e modelos para essas instituições.

Embora se reconheça a importância da universidade de pesquisa para o desenvolvimento científico e econômico do país, aplicam-se medidas de revisão de alguns traços essenciais do modelo de universidade propugnado por Humboldt, na Alemanha do século XIX. Um dos aspectos fundamentais dessa revisão é, exatamente, a adoção de visão mais pragmática e utilitária quanto à formação profissional e à produção de ciência e tecnologia. De um lado, trata-se de adequar os perfis profissionais às demandas do mercado de trabalho e do setor produtivo. De outro, a pesquisa só ganha sentido se contribuir para a formação de profissionais altamente qualificados, em atendimento às demandas do setor produtivo. Nesse âmbito, a unidade pesquisa-ensino torna-se necessária ao desenvolvimento do pensamento científico-tecnológico dos profissionais, uma vez que os recursos humanos altamente qualificados são considerados fundamentais no processo de competição das empresas. O crescimento de novas formas e mecanismos de interação universidade-empresa parecem indicar o êxito desse processo de revisão (Menegbel et alii, 1999).

Nos processos de revisão e ajuste das universidades públicas, os gestores oficiais das politicas informam que as parcerias da universidade com os setores industriais enriquecem o conhecimento, contribuem para o progresso da região, para o trabalho em equipe e até para a interdisciplinaridade. A necessidade de cooperação local, regional, nacional e internacional torna-se vital para as universidades, mesmo para a própria manutenção e desenvolvimento institucional, uma vez que os recursos dos fundos públicos são limitados progressivamente. Os defensores das parcerias afirmam que elas não provocam dispersão, ou seja, desvio dos interesses propriamente acadêmicos-científicos. $\mathrm{Na}$ verdade, acreditam que as universidades precisam aceitar a diversidade, o pluralismo e a diferenciação impostas pela sociedade contemporânea, já que não podem mais controlar a 
diversidade dispersiva por meio de um denominador comum, como a indissociabilidade ensino-pesquisa. Também, afirmam que não há como universalizar a universidade de pesquisa. A única alternativa é aceitar essa nova realidade dispersiva, diversa, plural e desigual. A multiversidade de funções só é possivel nas universidades de excelência; as demais instituições deviam investir em áreas e atividades em que seja possivel obter resultados satisfatórios.

A autonomia universitária, outro traço do modelo humboldtiano, na reforma atual, articula-se com uma ampla avaliação do desempenho institucional e docente, de responsabilidade do Estado avaliador, e com novos mecanismos de financiamento. Em que pesem as inúmeras tentações e as expectativas em relação às universidades, entende-se que estas devam ter autonomia para

pesquisar, ensinar e formar, contribuir na esfera pública, colocar sua competência à disposição da economia, acelerar o ritmo das inovações, liderar o processo econômico, favorecer o aperfeiçoamento das condições sociais, estimular melhor qualidade de vida, obter fundos externos para o financiamento da pesquisa (Casper, 1997: 46-47).

A dispersão é considerada um fenômeno universal. Por isso, espera-se que cada universidade se autodefina, em razão das suas potencialidades. Para tanto, no caso das universidades federais, o Estado deve ampliar a autonomia e a flexibilidade orçamentária, favorecendo o aumento da competição no campo.

A massificação da universidade na sociedade contemporânea é outra área impactante para as mudanças na educação superior e na universidade pública. Como resolver a disparidade entre crescimento da demanda e número efetivo de vagas nas universidades? A reforma da educação superior no Brasil está optando pela expansão do sistema por intermédio da diversificação e da diferenciação institucional, pelo crescimento do setor privado e pela ampliação das vagas nas universidades federais, sem gastos 
adicionais (Brasil. MEC, 2000; Souza, 1999, 2000a). A igualdade de oportunidades, segundo as capacidades individuais, definem o ingresso e o tipo de instituição em que cada um pode estudar. As universidades de pesquisa são consideradas onerosas e, por isso, não há como torná-las instituições de massa. Na verdade, a massificação implica saber quanto deverá ser pago, quem o pagará e a razão para fazê-lo, uma vez que se procura demonstrar a incapacidade financeira do Estado para assumir essa expansão do ensino superior (Durham, 1998a e b).

A solução para a expansão do ensino superior, mediante diversificação e diferenciação, no Brasil, não é muito diferente daquela pensada e colocada em prática, há algum tempo, em diferentes países da Europa e da América Latina. Dreze e Debelle (1983: 123), já em 1962, entendiam que

o problema de massa não deve ser proposto e pensado, somente, em termos de ensino universitário, mas, também, em termos de ensino superior não universitário. Em outros termos, a solução deve vir de uma rede diferenciada de instituições de ensino superior, onde cada tipo de instituição tem papel próprio, como elemento de um conjunto, cujas partes são solidárias e interconectadas.

Trata-se de

uma rede diferenciada de ensino superior, no seio da qual cada instituição possa se desenvolver, livremente, segundo sua vocação própria, enquanto o conjunto da rede de ensino esteja orientado para a realização de tarefas julgadas primordiais para a sociedade (Dreze e Debelle, 1983: 125).

Seria uma rede constituída de instituições de tipos diferentes, com funções diferentes. Por isso, segundo esses autores, não faz mais sentido pensar em uma concepção única de universidade, pelo contrário a reforma da universidade só tem sentido se é contínua e permanente (Dreze e Debelle, 1983: 124). Embora nas universidades pudessem tomar corpo concepções mais idealistas, o conjunto da rede receberia uma orientação funcional e mesmo pragmática. 
Parece evidente, portanto, que as transformações na sociedade, bem como os embates das Ifes com as forças em prol do ajustamento da universidade pública, notadamente em relação ao mercado, podem produzir, ao mesmo tempo, processos de ajuste, de resistência, de improvisação e de inovação. É claro que sempre há risco nesses processos, especialmente com o fim de desvirtuar as finalidades institucionais e a natureza histórica das universidades públicas. Um olhar mais geral dessa problemática permite inferir que os processos de adaptação levam a universidade pública a tomar a feição de empresas capitalistas, enquanto a resistência às mudanças produz uma inércia e uma conservação de padrões de trabalho acadêmico e de perfis institucionais não-condizentes com as exigências e desafios contemporâneos. Resta saber se as alterações, decorrentes desses processos, serão capazes de inovar, sem perder a essência de uma universidade pública. As improvisações ou as inovações nas universidades públicas, especialmente nas federais, poderão contribuir para a construção de alternativas institucionais de universidades qualificadas sem descaracterizá-las como instituições públicas de ensino, pesquisa e extensão comprometidas socialmente com o desenvolvimento do país?

Historicamente, as revoluções ou as rupturas no campo científicouniversitário parecem associadas às revoluções no campo político. É fato que a autonomia do campo científico-universitário restringe-se, na modernidade, em razão das condições objetivas e dos interesses externos ao campo (em cada tempo-espaço). A autonomia e a liberdade existente, atualmente, não asseguram independência em relação aos outros campos sociais, ao Estado e à sociedade de mercado. Todavia, é preciso levar em conta que o modo de ser e de agir do campo científico-universitário ou o modus operandi da universidade pública não implica, necessariamente, reprodução das condições objetivas ou completa subordinação ao mercado, o que parece se aplicar de forma clara, no Brasil, ao campo das universidades federais. 
O processo de modificação no relacionamento das universidades federais com o Estado e com o setor produtivo demonstra que ainda há espaço para inovação, mormente nos padrões de gestão e de organização, no modo de articulação com a sociedade, nas formas de manutenção e desenvolvimento institucional, bem como na produção do ensino e da pesquisa básica (e mesmo tecnológica). Os processos de inovação precisam articular o projeto de universidade à transformação da sociedade, ou seja, às lutas sociais e politicas em favor dos direitos democráticos, o que permite indagar, permanentemente, qual o papel dessa instituição social (denominada universidade) e "qual o lugar das idéias no processo de produção material da sociedade" (Chauí, 1998: 27). 


\section{CAPÍTULO II}

\section{A UNIVERSIDADE FEDERAL DE GOIÁS NO QUADRO DE METAMORFOSE DAS UNIVERSIDADES FEDERAIS}

Este capítulo tem como principal finalidade analisar a Universidade Federal de Goiás (UFG) no quadro de metamorfose das universidades federais brasileiras, apresentar sua situação acadêmica, bem como apontar mudanças fundamentais que ocorrem na instituição, em razão das atuais políticas de educação superior no Brasil, das novas demandas e desafios da sociedade contemporânea e das necessidades e condições objetivas do contexto institucional, local e regional.

Para compreender o processo de ajustamento, ou melhor, de metamorfose da UFG, é preciso inicialmente reconhecer sua situação acadêmica e seu perfil institucional. Para tanto, entende-se que essa universidade pode ser retratada, em parte, por meio dos seus principais indicadores acadêmicos, especialmente quando seqüenciados historicamente e analisados criticamente. Essa forma de exposição permite, em boa medida, uma maior visibilidade institucional e organizacional, tornando possivel apreender a especificidade do objeto de estudo, ou seja, o que é significativo para o caso.

O cenário institucional e organizacional, construído neste capítulo, estrutura-se com base nas seguintes questões: a) o que se espera da UFG no contexto da atual reforma da educação superior? b) o que mostram os principais indicadores acadêmicos acerca da situação dessa universidade? c) o que representa essa instituição no conjunto das universidades federais, ou melhor, que lugar ocupa nesse campo? d) que alterações e mudanças significativas tornam a UFG um caso típico do processo de metamorfose das universidades federais? 


\section{A Identidade institucional em questão}

A análise das políticas atuais de educação superior e das demandas, exigências e desafios da sociedade contemporânea, permite inferir o que se espera das universidades federais e, especialmente da UFG, na conjuntura atual, em termos de redefinição de sua identidade, particularmente no que tange a natureza e missão institucional52. As políticas de educação superior, gestadas e implementadas, desde o início do primeiro governo Fernando Henrique Cardoso, em 1995, enfatizam a necessidade de mudanças nas universidades federais, sobretudo com o objetivo de torná-las mais eficientes e eficazes no desempenho de suas missões. Qual natureza e missão institucional, porém, deve ter uma universidade como a UFG? Que nova identidade institucional poderá ou deverá ser gestada, considerando a orientação e a lógica propugnadas na atual reforma da educação superior?

A necessidade de mudança das Ifes ${ }^{53}$ decorre, em grande parte, de um diagnóstico situacional, produzido pelo governo, que aponta o esgotamento do modelo atual e a incapacidade, desse mesmo modelo, de atender aos novos cenários que se projetam e aos enormes "desafios da sociedade brasileira no terceiro milênio" (Castro, 1998). No balanço da educação superior, mormente das Ifes, realizado pelo $\mathrm{MEC}^{54}$, o esgotamento do modelo único é evidenciado, sobretudo, por meio de:

\footnotetext{
$52 \mathrm{O}$ uso, ou melhor, a difusão do termo missão é recente no Brasil, e amplamente utilizado nos documentos do Banco Mundial, da Unesco, do MEC e das Ifes, em geral. Ele se propaga exatamente no processo de instituição da reforma e parece indicar a busca de redefinição da vocação de cada IES. Além disso, vincula-se ao processo de alteração do padrão de gestão das Ifes, objetivando a implementação de um programa de qualidade total adequado à gestão dessas instituições. É preciso ressaltar, ainda, que boa parte dos pesquisadores do campo da educação superior, também, utilizam o termo missão sem evidenciar qualquer preocupação com a sua representação do ponto de vista ideológico.

$53 \mathrm{O}$ sistema federal de ensino superior é composto por 52 Ifes, sendo 39 universidades, oito faculdades e cinco centros de educação tecnológica. Cerca de $50 \%$ das universidades são autarquias e $50 \%$, fundações. Todas essas instituições vinculam-se à administração indireta do MEC e, por isso, estão sob sua supervisão.

54 A esse respeito, consultar: Brasil. MEC (1996) e Durham (1998b e c).
} 
a) elitização da universidade, ou seja, ausência de eqüidade ao acesso;

b) baixos percentuais de oferta, no panorama da América Latina, e estagnação das matrículas;

c) incapacidade do governo federal de continuar financiando e ampliando os recursos das universidades federais;

d) necessidade de racionalização dos gastos nas Ifes, em razão da despesa por aluno ser extremamente elevada;

e) insistência no modelo unificado de universidade de pesquisa, o que torna o sistema inflexivel e impede o atendimento à diversidade da demanda;

f) baixa produtividade científica e pouca vinculação da pesquisa às demandas tecnológicas e do setor produtivo;

g) inércia do sistema e, especialmente das Ifes, diante das transformações da sociedade contemporânea;

h) papel equivocado do Estado no financiamento e gerenciamento do sistema;

i) autonomia formal das Ifes e dos controles burocráticos excessivos;

j) currículos padronizados e inflexiveis;

k) baixa qualidade de grande parte dos cursos oferecidos.

De modo mais resumido, o ministro da educação, Paulo Renato Souza (1998), enumera seis aspectos que exigem uma reforma do ensino superior brasileiro: a) o esgotamento do modelo único baseado na indissociabilidade ensino-pesquisa-extensão; b) o tamanho do sistema extremamente modesto para as dimensões e necessidades do país; c) a inadequação do processo de credenciamento de novas instituições, gerando um sistema sem competição e de baixa qualidade; d) a falta de um sistema abrangente de avaliação do ensino de graduação; e) o desafio de modernizar o ensino de graduação; f) a ineficiência no uso dos recursos públicos na parte federal do sistema. 
Em lugar do modelo único da indissociabilidade ensino-pesquisaextensão, o governo propõe o modelo diversificado e flexivel, que permita uma expansão flexivel da oferta, absorvendo as demandas próprias desse processo dinâmico das mudanças sociais e econômicas em andamento no país. Nesse sentido, o governo estimula a expansão e a diversificação institucional do sistema, bem como a integração dos diferentes procedimentos de avaliação, credenciamento e recredenciamento, objetivando produzir um sistema baseado na flexibilidade, competitividade e avaliação (Brasil. MEC, 2000a; Catani e Oliveira, 2000b;).

Essas proposições adequam-se a um sistema cujas características e tendências marcantes são:

a) heterogeneidade do ponto de vista quantitativo e qualitativo55;

b) intensificação do processo de diversificação, flexibilização, diferenciação e segmentação horizontal e vertical do sistema;

c) ampla e excessiva regulamentação;

d) controle do Estado mediante diferentes processos e mecanismos de avaliação;

e) melhor qualidade dos cursos de graduação das IES públicas;

f) maior volume de pesquisas nas IES públicas, especialmente nas estaduais da região sudeste (Universidade de São Paulo - USP,

55 O sistema de educação superior no Brasil convive, atualmente, com duas configurações institucionais. Uma, fruto da legislação anterior à reforma, divide as IES em três grupos: a) Universidades; b) Federações de Escolas e Faculdades Integradas; c) Estabelecimentos Isolados. Essas instituições têm funções diferenciadas e podem ser públicas ou privadas. Quando públicas, são dependentes financeira e administrativamente da união (IES federal), dos estados (IES estadual) ou dos municipios (IES municipal). A outra configuração, resultado da nova LDB (Lei no 9.394/96) e da legislação complementar, torna o sistema mais heterogêneo e diversificado. Dividem-se as IES em Universidades, Centros Universitários, Faculdades Integradas, Faculdades e Institutos ou Escolas Superiores. A universidade passa a ser uma instituição caracterizada, sobretudo, pela produção intelectual institucionalizada, ou seja, pela qualidade da pesquisa, enquanto os Centros Universitários são marcados pela necessidade de manter ensino de excelência. Os demais formatos institucionais dedicam-se ao ensino. A universidade de campo passa a conviver com a universidade especializada. Além dos cursos de graduação, a atual reforma incentiva a criação de cursos póssecundários e cursos de caráter seqüencial, tanto nas IES indicadas acima como nas escolas técnicas e centros tecnológicos, como forma de ampliar a oferta e atender às demandas nesse nivel de ensino. 
Universidade Estadual de Campinas - Unicamp e Universidade Estadual Paulista - Unesp) e nas Ifes de médio e grande porte;

g) expansão do sistema ${ }^{56}$, sobretudo nas IES privadas;

h) maior presença do setor privado na oferta e no atendimento ao alunado $^{57}$;

i) melhoria crescente da qualificação docente;

j) enxugamento das funções docentes no setor público, especialmente nas Ifes;

k) aumento do número de alunos por docente e a diminuição do custo aluno médio nas Ifes;

1) crescimento da taxa de concluintes nas IES públicas;

m) redução orçamentária para manutenção das Ifes;

n) aprofundamento dos vínculos universidade-comunidade-setor produtivo;

o) busca de maior eficiência e produtividade acadêmica.

\begin{abstract}
56 De acordo com o Censo do Ensino Superior de 1998, o sistema contava com 973 IES, das quais $153(15,7 \%)$ eram universidades, 93 (9,6\%) Faculdades Integradas e Centros Universitários e 727 (74,7\%) Estabelecimentos Isolados. A maioria das IES concentrava-se nas regiões Sul e Sudeste. Além disso, o censo registrou que, "nos últimos quatro anos, a matricula de graduação apresentou uma taxa de expansão anual de 7\% em média. Em 1998, o aumento atingiu 9\%. Com isso, o número total de alunos em cursos de graduação saltou de 1 milhão e 945 mil, em 1997, para 2 milhões e 125 mil, em 1998. Incluindo-se os cursos de extensão, os seqüenciais e os de pós-graduação (especialização, mestrado e doutorado), o número total de alunos no ensino superior subiu para 2,7 milhões. A maioria dos alunos dos cursos de graduação está nas instituições privadas (1.321.229 - 62\%); em seguida, vêm as públicas federais ( 408.640 - 19,5\%), as estaduais (247.934 - 13,5\%) e as municipais ( 121.155 - 5\%). Para se ter uma idéia da velocidade dessa expansão, basta observar que o percentual de $9 \%$ é praticamente igual ao atingido pelo sistema em toda a década de 80, quando o ensino superior viveu um longo periodo de estagnação. Apenas nos últimos anos, o número de alunos matriculados aumentou 28\%, muito acima do alcançado em 14 anos, no periodo de 1980 a 1994, que foi de 20,6\%. De 1994 para cá, o número de alunos subiu 36,1\% nas instituições privadas, bem acima do crescimento verificado na rede pública". Nesta, o crescimento foi de 12,4\% nas federais, 18,5\% nas estaduais e 27,6\% nas municipais. A esse respeito, consultar dados da Sinopse estatística do ensino superior graduação 98 ( MEC.INEP, 1998) e da sintese intitulada Ensino superior mantém tendência de crescimento e diversificação (Brasil. MEC/Inep, 1999a).

57 O Censo da Educação Superior, realizado em 1999, mostra que o setor privado já responde por $65 \%$ das matrículas desse nivel de ensino.
\end{abstract}


Nesse quadro, as Ifes responsabilizam-se, em grande parte, pela necessidade de implementação de um substancial crescimento de vagas, uma vez que, segundo o executivo federal (Brasil. MEC/Inep, 1998: 49-54), os recursos empregados nessas instituições universitárias não satisfazem o que delas se espera em termos de produtos e serviços. Por isso, elas devem melhorar sua eficiência e racionalizar o uso dos recursos, considerando que a despesa por aluno é elevada e que a relação alunos/docente é extremamente baixa.

O novo modelo de educação superior, nos diagnósticos efetuados pelo governo, deve, também, contribuir para maior integração da universidade com o desenvolvimento regional e tecnológico, com o setor produtivo (empresas) e com os demais niveis e modalidades de educação. A articulação e as parcerias com o setor produtivo são fundamentais ao processo de metamorfose institucional, pois se espera, com esses processos de integração, que cada instituição encontre sua vocação e torne claro sua importância para o contexto local e regional, só assim a universidade demonstra sua relevância social ${ }^{58}$. Esse ajustamento subordina-se, portanto, à condições objetivas locais e regionais próprias, significando que, embora algumas exigências gerais sejam colocadas para o conjunto das Ifes, as respostas dessas instituições devem ser diferenciadas.

A reforma orienta, ainda, que essa reconfiguração da natureza e da missão seja alicerçada em amplo processo de avaliação interna e externa. A

\footnotetext{
58 A assunção do regional, ou seja, a direção regionalizante, é anunciada por vários reitores das Ifes. No caso da UFG, nas duas últimas gestões, observa-se claramente um empreendimento com o fim de identificar a universidade com a história da cidade e do estado de Goiás, com a formação de profissionais necessários ao progresso e ao desenvolvimento e com a solução dos problemas locais e regionais. Na gestão 1994-1998, o discurso de posse do Reitor afirmava que o propósito de trabalhar com perseverança para "fazer com que a Universidade deixe seus muros e vá ao encontro da sociedade" (UFG. Reitoria, 1998c). Por sua vez, na atual gestão, verifica-se grande esforço para aproximar a UFG da sociedade local. Na comemoração dos 38 anos da UFG, a Reitora, Milca Severino Pereira, afirmou que "a meta da instituição é mostrar que a universidade pertence a sociedade". Ressaltou, ainda, "ser importante que a população se sinta dona da UFG e, como tal, cuide bem dela" (Declarações feitas em Assembléia Universitária da UFG). A análise
} 
avaliação, nos moldes estabelecidos pelos documentos governamentais e legislação em vigor, deve sustentar a tomada de decisão e a captação de recursos, conforme competências e potencialidades existentes em cada universidade federal.

A finalidade básica do modelo diversificado e flexivel, porém avaliado permanentemente, refere-se à expansão das vagas existentes ${ }^{59}$, o que, no caso das Ifes, ocorrerá, sobretudo, com a racionalização no uso dos recursos, com a ampliação dos cursos e vagas e com a flexibilização curricular. E, nos demais casos, por meio do estímulo à criação de estabelecimentos mais voltados para o ensino, da ampliação do ensino tecnológico (pós-médio), da expansão dos cursos seqüenciais e do estabelecimento de parcerias entre a união, estados e instituições comunitárias ${ }^{60}$.

O MEC anuncia, também, que já há uma certa concordância com a Andifes quanto à necessidade de ampliação imediata das vagas. No Seminário para Expansão do Ensino Superior, realizado em dezembro de 1998, o ministro Paulo Renato Souza afirmou que o "MEC e a Andifes estão com o discurso cada vez mais afinado na hora de determinar a necessidade de expandir o acesso à Educação Universitária em todo o País" (Brasil. MEC, 1998b). A proposta do MEC, no seminário realizado, é a do crescimento das vagas entre $30 \%$ e $40 \%$, com "medidas de custo zero" 61 , pois para o ministério, "a atual estrutura suporta (...) um substancial incremento de vagas com a simples eliminação da capacidade ociosa dessas instituições" (Brasil. MEC, 2000a).

pormenorizada da direção dada à UFG é feita no capítulo seguinte e nas considerações finais.

59 Sobre a vinculação entre a expansão do ensino superior e o sistema de avaliação, consultar artigos do ministro da educação, Paulo Renato Souza, publicados em vários jornais, especialmente no ano de 1999.

60 Ver: Plano Nacional de Educação: Proposta do Executivo Federal ao Congresso Nacional (Brasil. MEC/Inep, 1998).

61 Ao que consta, não é esse o entendimento da Andifes. As posições mais recentes dessa entidade são as de que o sistema precisa crescer, mas a capacidade de desenvolver-se, com os recursos existentes, já foi esgotada. Ver: Brasil. MEC. Expansão do ensino superior. Notícias. Brasília: MEC, 17 dez. 1998 (www.mec.gov.br). 
Ao tempo em que propõe a ampliação das vagas e matriculas nas Ifes, o diagnóstico do governo reconhece a necessidade da existência de algumas instituições públicas de alta qualidade, de âmbito nacional, como referência para todo o sistema. São universidades com vocação e capacidade institucionais instaladas para a produção da pesquisa científica, mantidas em grande parte com recursos do Poder Público. Essas instituições devem ter apoio das fundações de amparo à pesquisa, objetivando a investigação científica e o incentivo à pós-graduação. São universidades no sentido mais amplo do termo, ou seja, caracterizadas pela produção do conhecimento científico. Em outras palavras, universidades de pesquisa ${ }^{62}$.

De um modo geral, esse breve panorama dos diagnósticos realizados pelo governo federal, bem como as análises efetuadas até aqui, permitem compreender o que se espera das Ifes nesse periodo de adaptação $e$ conformação, compreendido na reforma. De maneira especial, portanto, podese inferir que uma instituição como a UFG, dentre outros aspectos, deve:

a) definir a natureza/identidade e missão básica que possui no cenário acadêmico;

b) definir as reais vocações e potencialidades especificas;

c) contribuir decisivamente para o desenvolvimento do Estado e da região em que se insere;

d) expandir as vagas, sobretudo no período noturno, sem ampliar o quadro de docentes e técnico - administrativos, objetivando aumentar a relação aluno/professor;

e) otimizar a utilização das instalações físicas e dos equipamentos, bem como das habilidades docentes;

f) diminuir as taxas de reprovação e evasão;

62 Ver documentos: Plano Nacional de Educação: proposta do Executivo Federal ao Congresso Nacional (Brasil. MEC/Inep, 1998) e Uma politica para o ensino superior brasileiro: subsídios para discussão (Brasil. MEC, 1996), bem como Durham (1998a, b e c). 
g) reduzir os recursos destinados à residência estudantil, restaurantes, bolsas e subsidios;

h) flexibilizar o ensino, os cursos, os currículos e os programas de estudo;

i) melhorar a qualidade do ensino oferecido;

j) adequar os cursos de formação e os serviços às demandas do mercado de trabalho;

1) aperfeiçoar mecanismos de avaliação;

m) qualificar a gestão, racionalizar o uso dos recursos e estimular a produtividade;

n) buscar alternativas de financiamento;

o) flexibilizar a política de pessoal docente e técnicoadministrativo;

p) qualificar e titular docentes e servidores;

q) integrar pós-graduação/graduação;

r) consolidar a pesquisa e os programas de pós-graduação;

s) ampliar a produção e capacidade científica instalada;

t) desenvolver processos de inovação tecnológica de produção e difusão da ciência e da cultura;

u) exercer ampla autonomia ${ }^{63}$.

Como se vê, são complexas, múltiplas, diferenciadas e até conflitantes algumas das medidas e indicativos de alterações que pairam sobre as universidades, em especial sobre a UFG. Ao que parece, dificilmente uma universidade conseguirá fazer tudo, ou seja, cumprir toda essa extensa agenda com competência e qualidade, conforme as condições exigidas pela reforma. Na prática, espera-se que cada instituição redefina sua identidade com base no investimento estratégico em uma área específica, entendida

63 Acerca da autonomia universitária, na perspectiva de constituição das universidades federais como organizações sociais, consultar Silva Jr. e Sguissardi (1999a). 
como vocacional. A multiversidade ${ }^{64}$ de tarefas e ações reservam-se às instituições científicas de excelência. Por isso, definir vocação e otimizar as potencialidades existentes implica assumir, quase sempre, como objetivos e metas, alguns dos itens apontados, em detrimento de outros.

As universidades são induzidas a construir propostas mais regionalizantes. As universidades ajustadas, conforme espírito da reforma, adaptam-se às circunstâncias locais e, portanto, correspondem às expectativas e às necessidades de seu próprio contexto. Esse ideal de universidade prima pela aplicação do conhecimento, pela formação de profissionais adequados às demandas do mercado de trabalho, pela integração e parceria, pelo saber interessado na prestação de serviço e pela resolução de problemas locais e regionais.

Ao que parece, no entanto, as definições e os rumos das universidades federais não acontecem sem lutas, sem tensões ou sem tomadas de posição daqueles que exercem a gestão das instituições, das unidades acadêmicas, bem como dos movimentos organizados em cada universidade ${ }^{65}$. Essas definições deverão ocorrer de modo diverso no conjunto das Ifes, o que, de certo modo, se coaduna ao espírito do novo modelo, pois pretende a constituição progressiva de uma rede diferenciada de educação superior. A própria necessidade de sobrevivência institucional parece ser um fator de adequação de boa parte das universidades federais à lógica da reforma, uma vez que acabam reorientando principios, metas e ações da gestão universitária.

\footnotetext{
64 Termo bastante utilizado por Anísio Teixeira (1998a) para se referir às grandes universidades inglesas e americanas.

65 É preciso levar em conta, no entanto, o crescimento do processo de individualização dos docentes, sobre o qual se tem pouco ou nenhum controle acadêmico. Esse processo é fruto da precarização dos salários e condições de trabalho, da descrença no poder dos sindicatos e ações coletivas, bem como da formação de uma mentalidade mais pragmática e utilitária. A Gratificação de Estímulo à Docência (GED) parece reforçar ainda mais esse comportamento, uma vez que cada professor procura pautar suas atividades conforme a pontuação que obterá. A esse respeito consultar Catani e Oliveira (1999a).
} 
O desmonte do ideal unificado da indissociabilidade ensino-pesquisaextensão66, objeto histórico de reconhecimento e de construção das universidades federais, significa, evidentemente, uma transformação ou uma perda de identidade dessas instituições. Há, certamente, possibilidades e limites quanto à eficácia, ao dinamismo, à maleabilidade e à adaptabilidade que se requer de cada universidade federal. A funcionalidade, exigida das universidades federais, pode fazer desaparecer um tipo de cultura institucional mais livre e original para, em seu lugar, provocar o surgimento de um ideário mais utilitário, pragmático, funcional e de adaptação às necessidades econômicas, sociais e politicas de cada momento.

A vitalidade e o dinamismo de uma universidade federal expressam-se no contínuo e no permanente processo de adaptação às condições presentes, uma vez que a estagnação significa morte lenta e gradual e a possibilidade de ruptura, diante das políticas educacionais e da situação objetiva, torna-se bastante remota. Essa nova configuração faz com que cada universidade seja subsumida, em grande parte, pelos condicionantes que a produzem, do mesmo modo que a liberdade acadêmica e a critica radical sofrem os constrangimentos das novas tarefas e finalidades sócio-políticas e econômicas da instituição.

De um modo geral, a reforma da educação superior é imbuída da lógica da distinção, ou melhor, da diferenciação acadêmica67. Força uma alteração na identidade de cada instituição, uma vez que as universidades são levadas a assumir compromissos e a definir especificidades que, em tese, garantam performances mais eficazes e adequadas. Essa lógica, portanto, não respeita a identidade das instituições e as finalidades que cada uma delas vem

66 Durham (1998b: 30) entende que "o desmonte deste sistema é fundamental para a modernização do ensino superior e para sua adequação às exigências do mercado e do processo de desenvolvimento econômico".

67 No vernáculo, distinção significa ato ou efeito de distinguir. Assim, a distinção implica diferenciar, caracterizar, determinar, separar, discernir, discriminar e especificar qualidades e características existentes, classificando e tornando notável o que é distinto. 
delineando historicamente no contexto em que se situa (Dias Sobrinho, 1998; Trindade, 1999a).

Diferentes indicadores acadêmicos mostram que a UFG, atualmente, representa a média das universidades federais. Ao observá-la, mesmo do ponto de vista histórico, verifica-se que seu crescimento ocorre em um ritmo semelhante às demais universidades federais ${ }^{68}$, pois se trata de uma instituição de porte médio em vários aspectos: vagas na graduação; cursos ofertados; contigente de alunos, docentes, técnico-administrativos; relação aluno/docente, aluno/funcionário e funcionário/docente; qualificação docente; pesquisa; custo-aluno; remuneração dos docentes etc ${ }^{69}$ (Durham, 1998b; Amaral, 1998).

O formato médio-padrão da UFG, no conjunto das universidades federais, também expressa uma situação intermediária no panorama nacional, do ponto de vista do capital acadêmico que detém. A UFG, como espaço social, definido pelo lugar que ocupa na distribuição de um tipo específico de capital, produzido academicamente, possui uma posição $X$ no seu conjunto específico, o das universidades federais. No que diz respeito à concepção do modelo unificado de universidade, a posição da UFG parece seguir um ritmo e uma configuração solidária às demais universidades federais. Já no cenário do modelo diversificado e diferenciado, da reforma atual, seu lugar tende a ser questionado e a movimentar-se com mais intensidade, diante do processo de competição que se instala ${ }^{70}$ (Dourado e Oliveira, 1999; Catani e Oliveira, 1999a e b).

\footnotetext{
68 Estudá-la, portanto, significa obter uma visão do que ocorre no conjunto das universidades federais, ou seja, obter um padrão do comportamento dessas instituições.

69 Para se chegar a essa conclusão realizou-se ampla análise nos sites das universidades, nos catálogos do Conselho de Reitores das Universidades Brasileiras (Crub) e nos censos do ensino superior do MEC, além de recorrer a alguns estudos específicos sobre a questão.

70 Nesse sentido, começam a adquirir relevância questões, como: Que tipo de capital detém a UFG no conjunto das universidades federais? Com que capital ela participa do jogo da produção acadêmica nesse campo? O que ela representa para Goiás e para o Brasil? Em que direção essa universidade parece se movimentar? Que tipo de posição ela ambiciona? A UFG pode ser considerada uma universidade de pesquisa ou de ensino? Ela pode ser considerada uma universidade pequena, média ou grande no conjunto das universidades federais?
} 
Pode-se dizer que as estratégias de desenvolvimento e de investimento da UFG passam pelo capital acumulado que possui, sobretudo pelo capital intelectual, existente na instituição. As estratégias assumidas, fruto de um tipo de investimento, certamente definirão, a médio e longo prazos, a natureza da instituição. A vocação da instituição e sua missão resultarão, portanto, desse percurso de tomada de posição e definição de ações prioritárias ${ }^{71}$, no quadro de crescente e contraditórias demandas, que se originam em niveis local, regional, nacional e internacional.

\section{A situação acadêmica da UFG}

O reconhecimento da situação acadêmica e do perfil institucional e organizacional da UFG ajuda a perceber e a compreender o seu processo de metamorfose. Nesse sentido, uma descrição analítica da universidade, tomando por base, indicadores básicos da estrutura e da administração superior, da comunidade universitária e da qualificação docente, da graduação, da pesquisa e da pós-graduação e das medidas mais importantes no âmbito da gestão da instituição, pode evidenciar significativamente a dinâmica de constituição do perfil e da identidade institucional.

\subsection{A estrutura e a administração superior}

A UFG é uma instituição federal de ensino e pesquisa de nível superior vinculada ao MEC. Trata-se de uma autarquia pertencente à administração indireta daquele ministério, portanto, sob sua supervisão. É, até hoje, a única universidade federal existente no estado de Goiás; este, por sua vez, possui uma área de $341.289,5 \mathrm{~km}^{2}$ e uma população de 4.515 .868

\footnotetext{
71 Esse investimento da UFG não é uniforme. A universidade não é um todo coeso e unificado: constitui-se em uma estrutura de posições diferenciadas e variadas, uma vez que nela habitam diferentes concepções de mundo e ocorrem jogos acadêmicos diversificados e competitivos, frutos das disputas dos diferentes atores envolvidos no processo.
} 
habitantes, distribuídos em 242 municipios (Goiás, 1998). A UFG foi criada em 14 de dezembro de 1960, com a reunião de cinco escolas superiores já existentes em Goiânia: a Faculdade de Direito, a Faculdade de Farmácia e Odontologia, a Escola de Engenharia, o Conservatório de Música e a Faculdade de Medicina ${ }^{72}$. Nessa década, foram também criadas outras unidades acadêmicas bastante significativas para a estruturação da universidade ${ }^{73}$.

A UFG pode ser considerada uma instituição complexa do ponto de vista de suas dimensões burocráticas. No decurso de sua existência, especialmente desde meados da década de 80, ela empreendeu a construção de uma estrutura orientada pela busca de uma administração racional e ágil, pelo menos é o que preconizam a Assembléia Constituinte Interna (19881990) e a última reformulação estatutária (1994-1995) ${ }^{74}$. O novo formato organizacional, resultado do novo estatuto, que passou a vigorar a partir de 8 de novembro de 1996, buscou atender "aos atuais conceitos de administração estratégica e racional, com estruturas mais leves, menor número de níveis hierárquicos e maior autonomia". Em outras palavras, "um formato organizacional (...) mais enxuto, mais ágil e menos burocrático" (UFG. Jornal da UFG, 1998: 4).

A mudança do Estatuto e do Regimento, ocorrida em 1996, provocou o desmembramento de unidades acadêmicas e, conseqüentemente, o aumento

\footnotetext{
72 A UFG foi criada pela Lei no 3.834C, de 14 de dezembro de 1960 e reestruturada pelo Decreto no 63.817, de 16 de dezembro de 1968. Boa parte das Ifes foram criadas na década de 50 e início de 60, por meio de processos de federalização, mediante reunião de unidades acadêmicas existentes, como: Faculdades de Medicina, Direito, Engenharia e Farmácia. Em 1968, com a reforma universitária, as universidades federais passaram por processos de restruturação.

73 Sobre a história da criação da UFG, incluindo-se a aglutinação de instituições e a criação de novas unidades acadêmicas, sugere-se consultar a dissertação de mestrado de Baldino (1991), especialmente o Capítulo III.

74 A Assembléia Constituinte Interna (1988-1990), em razão das inúmeras divergências naquele momento, não conseguiu concluir a mudança estatutária, que veio a ocorrer posteriormente, no período 1994-1995.
} 
do seu número ${ }^{75}$. Assim, a UFG passou a contar com um total de 24 unidades acadêmicas ${ }^{76}$ distribuídas em oito áreas de conhecimento e nos dois campi de Goiânia, ou seja, no Campus Colemar Natal e Silva (Campus I), perto do centro da cidade, e no Campus Samambaia (Campus II), próximo à rodovia Goiânia-Nerópolis, a cerca de $12 \mathrm{~km}$ do centro, como mostra o anexo 2. Além dessas unidades acadêmicas, a UFG conta com Órgãos Suplementares 77 e com seis Campi Avançados: cinco no interior do estado (Catalão, Jataí, cidade de Goiás, Firminópolis e Rialma) e um em Porto Nacional (no estado do Tocantins).

O aumento do número de unidades acadêmicas, por ocasião da mudança estatutária, teve como contrapartida a diminuição do número de departamentos, que passou de 72 para 28. O novo Estatuto provocou um expressivo enxugamento no número de departamentos e uma limitação à sua criação ${ }^{78}$. Em compensação, parece ter incentivado o desmembramento de unidades acadêmicas, que acabou acomodando interesses existentes nas diferentes áreas de conhecimento de cada unidade ${ }^{79}$.

De acordo com o Estatuto e com o Regimento, cada unidade acadêmica é constituída por: Conselho Diretor, Diretoria, Coordenadoria dos Cursos de Graduação, Coordenadoria dos Programas de Pós-Graduação stricto sensu, Departamentos, quando houver. Podem existir, ainda, nas unidades

\footnotetext{
75 A análise do Estatuto e do Regimento indica que as mudanças efetuadas objetivam uma maior racionalização administrativa da universidade, para torná-la mais ágil e efeciente. Sobre a mudança do Estatuto e o desmembramento das unidades acadêmicas da UFG, consultar a dissertação de mestrado de Rodrigues (2000), que toma essas temáticas como objetos centrais de estudo.

$76 \mathrm{Se}$, como unidades acadêmicas forem contados, o Hospital das Clínicas (HC) e o Centro de Ensino e Pesquisa Aplicada à Educação (Cepae), esse número sobe para 26.

77 Os organismos de apoio ao ensino, pesquisa, administração e serviços incluem: Biblioteca Central, Hospital das Clínicas, Centro de Processamento de Dados (CPD), Hospital Veterinário, Centro Editorial e Gráfico (Cegraf), Teatro Universitário, Museu Antropológico, Planetário, Escritório Modelo (Faculdade de Direito), Restaurante Universitário e Escritório Modelo Design (Instituto de Artes).

78 Em dezembro de 1999, o Conselho Universitário decidiu pela extinção gradativa dos departamentos que sobreviveram à mudança estatutária, em razão da necessidade de repassar para os novos coordenadores de cursos de graduação as funções gratificadas (FGs) dos chefes de departamentos.

79 A esse respeito, conferir o trabalho de Rodrigues (2000).
} 
acadêmicas, Núcleos de Estudos e Pesquisas e Órgãos Complementares, instituídos pelo Conselho Diretor da unidade.

Já a administração central da universidade é formada pela Reitoria80 e pelos seguintes conselhos deliberativos superiores: Conselho Universitário (Consuni), Conselho de Curadores e o Conselho Coordenador de Ensino, Pesquisa, Extensão e Cultura (Cepec). O último conselho estrutura-se em duas instâncias de deliberação: Plenário e Câmaras Setoriais - Câmara de Graduação, Câmara de Pesquisa e Pós-Graduação e Câmara de Extensão e Cultura. A Assembléia Universitária e o Conselho de Integração Universidade-Sociedade, também previstos na estrutura acadêmica e administrativa da instituição, não são deliberativos.

A Reitoria, organismo executivo da administração superior da universidade, compreende: Gabinete do Reitor, Pró-Reitorias, Procuradoria Jurídica, Coordenadorias e Assessorias Especiais, Órgãos Suplementares, Campi do interior, Órgãos Administrativos. As Pró-Reitorias, definidas no Estatuto como responsáveis em supervisionar e coordenar as respectivas áreas de atuação, são as seguintes: Pró-Reitoria de Graduação, Pró-Reitoria de Pesquisa e Pós-Graduação, Pró-Reitoria de Extensão e Cultura, PróReitoria de Administração e Finanças, Pró-Reitoria de Desenvolvimento Institucional e Recursos Humanos e Pró-Reitoria de Assuntos da Comunidade Universitária.

Como visto anteriormente, essa estrutura foi montada para tornar a universidade mais ágil e menos burocrática. Em que pese esse ideário, a reformulação administrativa efetuada parece ter conservado os elementos centrais de uma organização burocrática de tipo ideal (Weber, 1971). A divisão do trabalho, as normas extensivas e a organização de cargos por meio de quadro administrativo hierárquicos delimitados por normas técnicas e

80 Desde sua criação, a UFG já teve 11 reitores, como mostra o anexo 3. Observa-se que somente o segundo reitor não completou o mandato e que apenas duas mulheres chegaram 
com áreas específicas de competências são alguns dos atributos de uma forma burocrática de organização que continuam presentes na modelação estatutária e regimental da UFG. Além disso, buscou-se institucionalizar uma racionalidade administrativa orientada pela eficiência técnica, o que deve ocasionar uma maior formalização dos processos administrativos que objetivam os interesses da instituição ${ }^{81}$.

\subsection{A comunidade universitária e a qualificação dos recursos humanos}

Os dados de 30 de dezembro de 199982, no tocante aos docentes, servidores técnico - administrativos e alunos, indicam que a comunidade universitária da UFG83 apresenta a seguinte composição: docentes - 1.270, sendo 1.133 efetivos, 132 substitutos e cinco visitantes; técnicoadministrativos - 1.943; alunos - 15.133, sendo 12.351 cursos de graduação, 1.152 de especialização, 679 de mestrado, 22 de doutorado, 701 de ensino fundamental e médio (no Colégio de Aplicação) e 228 de prégraduação (na Escola de Música) ${ }^{84}$.

A situação de titulação dos docentes efetivos, em 30 de dezembro de 1999, era a seguinte: 106 (10\%) graduados, 249 (22\%) especialistas, 452 (40\%) mestres e 326 (29\%) doutores. Dos 132 professores substitutos, 97 (73\%) eram graduados. Nesse período, havia cerca de 16\% de docentes do quadro efetivo cursando mestrado ou doutorado. É preciso salientar, ainda,

a exercer essa função - uma, no final do Regime Militar, e outra, presentemente, durante a atual reforma da educação superior.

81 Segundo Cunha (1999: 128) as universidades precisariam de certo grau de desordem, uma vez que a busca do conhecimento não pode existir em sistemas monoliticos. Esse autor propõe, portanto, repensar a gestão universitária em uma perspectiva de anarquia organizada.

82 Dados fornecidos pela Pró-Reitoria de Desenvolvimento Institucional e Recursos Humanos da UFG.

83 A UFG, quando comparada a outras Ifes, apresenta percentuais médios na relação aluno/docente, aluno/funcionário e funcionário/docente.

84 Em reunião com parlamentares goianos, no dia 3 de dezembro de 1999, a Reitoria apresentou documento contabilizando um total de 17.348 alunos, em cujo contingente 
que, dos docentes efetivos, 76\% dedicavam-se integralmente à universidade, ou seja, tinham contratos em regime de dedicação exclusiva ${ }^{85}$.

Segundo Durham (1998b), baseando-se em outros dados, é de 9,0\% a relação aluno/docente na $\mathrm{UFG}$, de 5,19\% a relação aluno/funcionário e de $1,74 \%$ a de funcionário/docente. Esses percentuais evidentemente seriam outros, se considerados os dados de 1999 e de 2000 e se contabilizados os demais alunos da universidade, especialmente de pós-graduação, com pontuação diferente aos dos alunos da graduação, como propõe a Andifes.

Segundo Amaral (1998: 93), caso fossem observados os recursos efetivamente gastos com o ensino, a pesquisa e a extensão, também com uma modelagem que considerasse o número total de alunos equivalentes aos de graduação, a UFG teria um custo/aluno de $\mathrm{R} \$ 5.205,00$. A modelagem proposta, de acordo com parâmetros internacionais, implicaria também o aumento significativo da relação aluno/docente e aluno/funcionário, na UFG e nas demais Ifes.

Nos últimos anos, a UFG, assim como todas as Ifes, enfrenta forte pressão governamental para reduzir o custo-aluno, o que fica evidenciado, por exemplo, na diminuição crescente do número de docentes e servidores técnico-administrativos, em virtude sobretudo das aposentadorias e óbitos, como registra a tabela 1 .

incluíram-se também os alunos do Centro de Línguas e alunos de projetos especiais de formação de professores.

${ }^{85}$ A escolaridade dos funcionários apresentava-se da seguinte forma: nove mestres, 23 especialistas, um com curso de aperfeiçoamento, 627 graduados, 1.096 com ensino médio e 187 com ensino fundamental. 
Tabela 1 - Evolução do número de docentes e técnico-administrativos da UFG no período de março de 1998 a março de 2000

\begin{tabular}{|c|c|c|c|}
\hline ANO & MÊS & DOCENTES & TÉCNICOS-ADM. \\
\hline 1998 & Março & 1.283 & 2.076 \\
\hline 1999 & Abril & 1.155 & 1.997 \\
\hline 1999 & Dezembro & 1.133 & 1.943 \\
\hline 2000 & março & 1.130 & 1.938 \\
\hline
\end{tabular}

Fonte: dados obtidos em vários documentos da UFG.

Essa situação torna-se ainda mais grave por causa da proibição de abertura de concursos e da pressão para que a UFG e as Ifes, em geral, ampliem a oferta de vagas, sobretudo para os cursos de graduação noturnos 86 . Ao lado disso, no caso da UFG, verificam-se pontos de estrangulamento no processo de trabalho, como:

\begin{abstract}
desmotivação e descompromisso por parte de muitos dos servidores, diante da conjuntura que as Ifes estão vivenciando; qualificação insuficiente para o desempenho das funções que estão sendo exigidas para o crescimento que as unidades acadêmicas particularmente tem sentido, com a duplicação de jornada de trabalho; dificuldades nas relações interpessoais, escassez de planejamento, dificuldade no gerenciamento e gestão de pessoas, inadaptação por problemas de saúde. Todos estes pontos tem agravado o problema do quantitativo e do qualitativo de pessoal (UFG. Ata do Consuni, 28 maio 1999) ${ }^{87}$.
\end{abstract}

De um modo geral, a questão salarial, vinculada a uma crescente precarização das condições de trabalho, parece implicar uma mudança de

86 Para o ano letivo de 1999, as unidades acadêmicas solicitaram 159 professores substitutos, sendo contratados apenas 124. Para o ano 2000, pediram 190 professores substitutos.

87 Esses pontos de estrangulamento foram identificados por pesquisa realizada pelo DDRH/UFG. Ver: UFG. Ata do Consuni, realizada no dia de 28 maio de 1999. 
comportamento dos docentes promovendo, sobretudo, alterações na produção do trabalho acadêmico 88 .

\subsection{A graduação}

A situação da graduação na UFG pode ser vislumbrada, em grande parte, com base em perfil estatístico que contemple, sobretudo, número de alunos, vagas no vestibular e nos cursos de graduação, avaliação dos cursos pelo Exame Nacional de Cursos (ENC), número de concluintes e inscrições no vestibular.

O número de alunos matriculados nos cursos de graduação da UFG, no período 1990-1997, aumentou paulatinamente. A tabela 2 mostra, no entanto, que seu crescimento foi expressivo na primeira metade da década de 90, sendo maior em 1994 (932 alunos) e em 1992 (727 alunos). Os três últimos anos apresentaram uma diminuição gradual no número de alunos, e em 1997, houve uma expansão de apenas 56 alunos. Essa situação contribuirá, como veremos mais adiante, para que a administração superior da universidade assumisse uma postura mais agressiva no tocante a expansão de vagas na graduação e à flexibilização curricular.

Tabela 2 - Número de alunos matriculados e crescimento das matrículas nos cursos de graduação, por ano letivo

\begin{tabular}{|c|r|r|r|r|r|r|r|r|}
\hline Ano & $\mathbf{1 9 9 0}$ & $\mathbf{1 9 9 1}$ & $\mathbf{1 9 9 2}$ & $\mathbf{1 9 9 3}$ & $\mathbf{1 9 9 4}$ & $\mathbf{1 9 9 5}$ & $\mathbf{1 9 9 6}$ & $\mathbf{1 9 9 7}$ \\
\hline Matrículas & 6.900 & 7.480 & 8.207 & 8.827 & 9.759 & 10.135 & 10.486 & 10.542 \\
\hline $\begin{array}{c}\text { Matrículas } \\
\text { Acrescidas }\end{array}$ & --- & 580 & 727 & 620 & 932 & 376 & 351 & 56 \\
\hline
\end{tabular}

Fontes: UFG. Informações 1996, p. 9; UFG. Relatório de Gestão 1994-1997, p. 22.

\footnotetext{
${ }^{88}$ A esse respeito, consultar estudo sobre os efeitos da GED no trabalho acadêmico (Catani e Oliveira, 1999a).
} 
A prática indica que o crescimento no número de alunos associa-se ao aumento de vagas no processo seletivo (vestibular), no qual se registra, a cada ano, uma expansão das vagas, mesmo que de forma irregular (tabela 3). A série histórica da evolução de vagas no vestibular da UFG indica esforço constante para ampliar as vagas ${ }^{89}$. Em 1991, 1995, 1998 e 1999 ocorreram as ampliações mais consideráveis ${ }^{90}$.

Para o ano letivo de 2000, foram ofertadas 3.020 vagas, distribuídas da seguinte forma: 2280 para os cursos de Goiânia, 300 para Catalão, 350 para Jataí, 30 para Rialma e 60 para a cidade de Goiás. Ao todo, são 66 cursos de graduação, e 19 funcionam no período noturno. As licenciaturas cobrem cerca de $50 \%$ dos cursos ofertados na instituição. Um percentual significativo de cursos de licenciatura é oferecido nos campi do interior do Estado de Goiás (UFG. CECV, 1999).

De 1994 a 2000 (anexo 4), o crescimento de vagas foi maior no ano de 1999, sobretudo nos cursos de licenciatura no período noturno (Tabela 3) ${ }^{91}$. Essa expansão coincidiu com o momento em que o MEC aumentou as vagas nas Ifes com medidas de custo zero e, também, com uma diretriz da LDB (§ $4 \underline{0}$ do art. 47 da Lei no 9.394/96) para o oferecimento de vagas obrigatórias no período noturno, a qual, ao que parece, plenamente atendida pelo

\footnotetext{
89 É provável que essa medida esteja ocorrendo na maioria das Ifes. No entanto, as universidades paulistas (USP, Unicamp e Unesp) não registraram crescimento das vagas na graduação nos últimos anos. A USP, por exemplo, ofereceu 6.902 vagas em 1994, 6.872, em 1995, 6.902, em 1996 e 6.920 , em 1998.

90 Além desses aumentos, é preciso registrar ainda os convênios que são assinados, particularmente com os municípios, objetivando a formação de professores. Em 1999, por exemplo, a Faculdade de Educação da UFG iniciou curso de graduação em Pedagogia para 396 novos alunos originários da rede municipal de Goiânia (UFG. Ata do Consuni, 20 ago. 1999, p. 7).

${ }^{91}$ O crescimento das vagas, ocorrido em 1999, deu-se sobretudo com a oferta dos seguintes cursos: Engenharia de Alimentos; Engenharia de Computação (noturno); Comunicação Social, habilitação Publicidade; Design de Moda; Musicoterapia; Licenciatura em Matemática (noturno), Licenciatura em Geografia (noturno); Bacharelado e Licenciatura em História (noturno); e Licenciatura em Educação Física (vespertino).
} 
conjunto das Ifes, que se destacam pelo "crescimento generalizado nos índices de produtividade" (Oliveira, 2000). ${ }^{92}$.

Cabe salientar que a ampliação das vagas, no caso da UFG, ocorre sem que houvesse crescimento do número de professores do quadro efetivo, uma vez que as vagas para realização de concurso para contratação de docentes não foram liberadas pelo $\mathrm{MEC}$, nos últimos anos. Na realidade, o quadro de professores efetivos vem caindo ${ }^{93}$. Por isso, o empreendimento da UFG parece atender intencionalmente à política do ministério ${ }^{94}$. Ocorre que essa universidade está optando mais intensamente pela criação de novos cursos ${ }^{95}$, o que parece não se coadunar à exigência da otimização dos recursos existentes.

92 Otom Anselmo de Oliveira é Reitor da Universidade Federal do Rio Grande do Norte (UFRN).

93 Na UFRN, o quadro de professores caiu de 1.770 para 1.480 , nos últimos anos. Mesmo assim, segundo Otom Anselmo de Oliveira, Reitor da universidade, ocorreu uma "expansão de $83 \%$ das vagas no vestibular, com a pós-graduação stricto sensu evoluindo de 16 para 35 cursos de mestrado e doutorado e com o número de doutores passando de $12 \%$ para 23\% do quadro docente". Além disso, "a UFRN ofereceu ainda, via convênios com secretarias de educação, 1.500 vagas no curso de Pedagogia" (SBPC. Jornal da Ciência. 11 fev. 2000, p. 2). ${ }_{94}$ Um caso exemplar na UFG, a respeito da expansão do ensino de graduação, ocorreu com o curso de Veterinária no campus de Jataí/GO. A Escola de Veterinária resolveu suspender o vestibular do curso de Veterinária-Jataí para o ano 2000, alegando falta de condições para funcionamento do curso. No entanto, o Cepec, em sessão realizada no dia 21 de novembro de 1999, votou pela manutenção do vestibular, com 14 votos a favor, 13 contra e quatro abstenções, e a totalidade dos ocupantes de cargos da Reitoria votaram favoráveis à manutenção do vestibular (UFG. Cepec, 21 nov. 1999)..

95 A comparação da UFG com outras Ifes permite perceber que, embora seja elevado o número de cursos oferecidos na instituição, é relativamente baixo o número de vagas ofertadas. 
Tabela 3 - UFG: Número de vagas oferecidas, acréscimo de vagas, candidatos inscritos e relação candidato vaga no período 1994-2000

\begin{tabular}{|c|c|c|c|c|}
\hline Ano & Vagas Oferecidas & $\begin{array}{c}\text { Acréscimo de } \\
\text { vagas }\end{array}$ & $\begin{array}{c}\text { Candidatos Inscritos } \\
\text { no vestibular }\end{array}$ & $\begin{array}{c}\text { Relação Candidato / } \\
\text { Vaga }\end{array}$ \\
\hline 1994 & 2.283 & - & 16.636 & 7,28 \\
1995 & 2.283 & - & 16.013 & 7,01 \\
1996 & 2.398 & 115 & 17.335 & 7,22 \\
1997 & 2.458 & 60 & 19.519 & 7,94 \\
1998 & 2.585 & 127 & 20.361 & 7,87 \\
1999 & 2.971 & 386 & 23.257 & 7,83 \\
2000 & 3.020 & 49 & 27.405 & 9,07 \\
\hline
\end{tabular}

Fontes: UFG. Relatório de Atividades da Gestão 1998-2001, relativo ao período de 6 jan. 1999 a 6 jan. 2000, p. 7.

Por sua vez, a situação da UFG, pelos resultados do Provão, não é considerada muito boa quando comparada com o quadro nacional (tabela 4), embora esteja melhor em relação às IES do Estado de Goiás. Apenas os cursos de Matemática, de Rialma/GO e Engenharia Civil, de Goiânia/GO, avaliados em 1999, obtiveram conceito A. Os cursos de Medicina, Medicina Veterinária e Matemática, de Goiânia alcançaram conceito $B$, enquanto sete outros cursos registraram conceito $C$ e dois o conceito $D$. Mesmo assim, o aumento no comparecimento à freqüência na realização dos exames, incentivado pela administração da instituição, certamente contribuiu para a melhoria dos conceitos em alguns cursos. 
Tabela 4 - Conceitos atribuídos pelo ENC aos cursos de graduação da UFG, por ano (1996 a 1999)

\begin{tabular}{|l|c|c|c|c|}
\hline \multicolumn{1}{|c|}{ CURSO } & $\mathbf{1 9 9 6}$ & $\mathbf{1 9 9 7}$ & $\mathbf{1 9 9 8}$ & $\mathbf{1 9 9 9}$ \\
\hline Direito - Goiânia & $\mathrm{E}$ & $\mathrm{B}$ & $\mathrm{C}$ & $\mathrm{C}$ \\
\hline Direito - Goiás & $\mathrm{E}$ & $\mathrm{E}$ & $\mathrm{E}$ & $\mathrm{D}$ \\
\hline Engenharia Civil & $\mathrm{E}$ & $\mathrm{D}$ & $\mathrm{E}$ & $\mathrm{A}$ \\
\hline Engenharia Elétrica & - & - & $\mathrm{E}$ & $\mathrm{C}$ \\
\hline Jornalismo & - & - & $\mathrm{B}$ & $\mathrm{C}$ \\
\hline Letras - Goiânia & - & - & $\mathrm{C}$ & $\mathrm{C}$ \\
\hline Letras - Catalão & - & - & $\mathrm{C}$ & $\mathrm{D}$ \\
\hline Letras - Jataí & - & - & $\mathrm{B}$ & $\mathrm{C}$ \\
\hline Matemática - Goiânia & - & - & $\mathrm{B}$ & $\mathrm{B}$ \\
\hline Matemática - Catalão & - & - & $\mathrm{B}$ & $\mathrm{C}$ \\
\hline Matemática - Rialma & - & - & $\mathrm{B}$ & $\mathrm{A}$ \\
\hline Medicina Veterinária & - & $\mathrm{C}$ & $\mathrm{E}$ & $\mathrm{B}$ \\
\hline Odontologia & - & $\mathrm{C}$ & $\mathrm{C}$ & $\mathrm{C}$ \\
\hline Medicina & - & - & - & $\mathrm{B}$ \\
\hline
\end{tabular}

Fonte: dados obtidos em vários documentos da UFG.

A avaliação das condições de oferta dos cursos de graduação da UFG (tabela 5), realizada por comissões de especialistas, designadas pelo MEC, permite, de certo modo, mostrar que há equívocos a respeito dos conceitos atribuídos pelo Provão e, por isso, esse exame não pode ser tomado como veredicto final, mas como indicador de um processo de avaliação mais amplo. A maioria dos cursos avaliados na UFG registraram condições muito boas ou boas, especialmente no tocante ao corpo docente e à organização didáticopedagógica. O maior problema, registrado especialmente no curso de Jornalismo, em 1999, foi o da insuficiência das instalações físicas ${ }^{96}$.

$96 \mathrm{Na}$ avaliação das condições de oferta dos cursos de graduação, em 1999, o maior problema encontrado nas instituições federais foi, sobretudo, a deficiência nas instalações, o que se deve, na opinião de muitos pró-reitores de graduação, à falta de verbas (Folha de S. Paulo. São Paulo, 17 fev. 2000, p. 5). 
Tabela 5 - Avaliação do corpo docente, organização didático-pedagógica e instalações, por curso de graduação da UFG

\begin{tabular}{|l|c|c|c|c|}
\hline \multicolumn{1}{|c|}{ CURSO } & $\begin{array}{c}\text { ANO } \\
\text { DE } \\
\text { AVALIAÇão }\end{array}$ & $\begin{array}{c}\text { CORPO } \\
\text { DOCENTE }\end{array}$ & $\begin{array}{c}\text { ORGANIZAÇÃO } \\
\text { DIDÁTICO - } \\
\text { PEDAGÓGICA }\end{array}$ & INSTALAÇõES \\
\hline Engenharia Civil & 1997 & $\mathrm{CB}$ & $\mathrm{CMB}$ & $\mathrm{CB}$ \\
\hline Direito & 1997 & $\mathrm{CB}$ & $\mathrm{CB}$ & $\mathrm{CR}$ \\
\hline Medicina Veterinária & 1998 & $\mathrm{CB}$ & $\mathrm{CMB}$ & $\mathrm{CB}$ \\
\hline Odontologia & 1998 & $\mathrm{CMB}$ & $\mathrm{CB}$ & $\mathrm{CB}$ \\
\hline Engenharia Elétrica & 1999 & $\mathrm{CB}$ & $\mathrm{CB}$ & - \\
\hline Jornalismo & 1999 & $\mathrm{CB}$ & $\mathrm{CI}$ & $\mathrm{CI}$ \\
\hline
\end{tabular}

Fonte: MEC/SESu - Relatório Síntese 1998. Dados complementares obtidos em vários documentos da UFG. -CMB - Condições Muito Boas • •CB - Condições Boas • •CR - Condições Regulares $\bullet \mathrm{CI}-$ Condições Insuficientes $\bullet$ SC Sem Conceito

Os dados da graduação da UFG ganham outros significados quando comparados aos de outras Ifes ${ }^{97}$. A UFG está entre as Ifes com maior número de cursos de graduação, como mostram as tabelas 6 e 7, não significando, que seja maior o número de vagas e matrículas. Ocorre que muitas Ifes preferem aumentar o número de vagas nos cursos já existentes ou criar novas habilitações, medida mais racional do que a criação de novos cursos. Essas tabelas revelam ainda que é baixo o número de concluintes, em relação ao número de vagas ofertadas e ingressos, especialmente em Ifes consideradas grandes, como: Universidade Federal do Rio de Janeiro (UFRJ), Universidade Federal da Paraíba (UFPB) e Universidade de Brasília (UnB). Nesse aspecto, a UFG está entre as mais eficientes. As três Ifes que apresentam percentuais mais elevados na relação matriculados/docentes são: Universidade do Amazonas (UAM), Universidade Federal do Pará (UFPA) e Universidade Federal do Espírito Santo (UFES), ou seja, são instituições

97 Optamos por uma amostragem regional das Ifes, tomando como critério de escolha o número de alunos na graduação, e o número de programas de mestrado e doutorado de cada instituição. Foram escolhidas três Ifes por região, julgadas representativas. Na região Sudeste foi incluída uma quarta universidade federal, a Universidade Federal de São Carlos (UFSCar), uma vez que essa Ifes pode ser considerada representativa do estado de São Paulo. 
mais caracterizadas pela oferta do ensino de graduação. Nesse item, a UFG apresenta uma relação intermediária $(8,7 \%)$ no conjunto das Ifes.

Tabela 6 - Número de cursos, concluintes, em 1995, matrícula e funções docentes em 30 de abril, segundo amostragem regional das Ifes -1996

\begin{tabular}{|c|c|c|c|c|c|c|c|}
\hline Região & IFES & Cursos & $\begin{array}{c}\text { Conclusão } \\
\text { em } \\
1995\end{array}$ & Matrícula & $\begin{array}{c}\text { Total } \\
\text { de Docentes }\end{array}$ & $\begin{array}{l}\text { Docentes } \\
\text { em } \\
\text { Exercício }\end{array}$ & $\begin{array}{c}\text { Relação } \\
\text { Matricul. / } \\
\text { Docentes }\end{array}$ \\
\hline \multirow[t]{3}{*}{ Norte } & UFPA & 140 & 2.616 & 20.804 & 2.049 & 1.806 & 10,1 \\
\hline & UAM & 47 & 1.109 & 12.879 & 858 & 670 & 15,0 \\
\hline & UFAC & 27 & 463 & 2.900 & 353 & 300 & 8,2 \\
\hline \multirow[t]{3}{*}{ Nord. } & UFBA & 56 & 1.948 & 16.750 & 1.841 & 1.636 & 9,0 \\
\hline & UFC & 44 & 1.434 & 10.704 & 1.473 & 1.245 & 7,2 \\
\hline & UFPB & 66 & 2.275 & 17.753 & 2.818 & 2.818 & 6,3 \\
\hline \multirow[t]{4}{*}{ Sudeste } & UFES & 42 & 1.010 & 10.174 & 1.014 & 919 & 10,0 \\
\hline & UFMG & 37 & 3.068 & 17.841 & 1.906 & 1.420 & 9,3 \\
\hline & UFRJ & 57 & 2.549 & 27.129 & 3.355 & 3.304 & 8,1 \\
\hline & UFSCar & 26 & 538 & 4.364 & 628 & 483 & 6,9 \\
\hline \multirow[t]{2}{*}{ Sul } & UFPR & 39 & 2.019 & 15.153 & 2.120 & 1.906 & 7,1 \\
\hline & UFRGS & 47 & 1.778 & 16.974 & 2.367 & 2.201 & 7,1 \\
\hline \multirow{4}{*}{$\begin{array}{l}\text { Centro } \\
\text { Oeste }\end{array}$} & UFSC & 38 & 1.889 & 16.046 & 1.840 & 1.527 & 8,7 \\
\hline & UNB & 53 & 1.375 & 13.581 & 1.693 & 1.245 & 8,0 \\
\hline & UFMT & 42 & 1.294 & 10.455 & 1.164 & 930 & 9,0 \\
\hline & UFG & 50 & 1.669 & 10.144 & 1.157 & 1.014 & 8,7 \\
\hline
\end{tabular}

Fonte: Brasil. MEC/Inep. Sinopse Estatística do Ensino Superior de Graduação - 1996.

A tabela 7 demonstra, ainda, que a relação candidato/vaga é maior nas seguintes instituições: Universidade Federal do Paraná (UFPR), Universidade Federal de Minas Gerais (UFMG), Universidade de Brasília (UnB) e Universidade Federal do Ceará (UFC), o que talvez se explique pelo fato de que essas Ifes gozam de prestígio acadêmico e estão localizadas em regiões com maior demanda para o ensino superior. O vestibular representa a principal forma de acesso aos cursos de graduação, embora algumas instituições registrem números elevados em outros meios de ingresso 98 .

98 A LDB (Lei no 9.394/96) eliminou, de certo modo, o vestibular tradicional, incentivando a adoção de novos mecanismos de escolha nos processos seletivos. É necessário salientar, ainda que, mesmo no vestibular tradicional, há diferenças substanciais nos critérios e procedimentos de classificação. 
Observa-se, também, que a UFRJ, a UFPR e a Universidade Federal do Mato Grosso (UFMT) aprovam mais candidatos que o número de vagas existentes.

Tabela 7 - Número de vagas oferecidas, relação candidato/vaga, aprovados e ingressos, segundo amostragem regional das Ifes - 1998

\begin{tabular}{|c|c|c|c|c|c|c|c|}
\hline Região & Ifes & Vagas & $\begin{array}{c}\text { Inscrições } 1^{\mathbf{a}} \\
\text { opção }\end{array}$ & $\begin{array}{l}\text { Candidato } \\
\text { / vaga }\end{array}$ & Aprovados & $\begin{array}{l}\text { Ingressos } \\
\text { pelo } \\
\text { vestibular }\end{array}$ & $\begin{array}{c}\text { Ingressos } \\
\text { por outras } \\
\text { formas } \\
\end{array}$ \\
\hline \multirow[t]{3}{*}{ Norte } & UFPA & 3.760 & 29.618 & 7,88 & 3.281 & 3.286 & 249 \\
\hline & UAM & 1.685 & 15.940 & 9,46 & 1.685 & 1.685 & 0 \\
\hline & UFAC & 850 & 6.484 & 8,05 & 806 & 796 & 70 \\
\hline \multirow[t]{3}{*}{ Nord. } & UFBA & 3.580 & 33.100 & 9,25 & 3.581 & 2.697 & 401 \\
\hline & UFC & 2.652 & 29.782 & 11,23 & 3.491 & 2.308 & 730 \\
\hline & UFPB & 4.293 & 18.177 & 4,23 & 3.702 & 3.708 & 281 \\
\hline \multirow[t]{4}{*}{ Sudeste } & UFES & 2.340 & 18.588 & 7,94 & 2.341 & 2.275 & 107 \\
\hline & UFMG & 3.485 & 41.879 & 12,02 & 3.487 & 3.468 & 564 \\
\hline & UFRJ & 6.150 & 54.254 & 8,82 & $40.275^{*}$ & 5.764 & 470 \\
\hline & UFSCar & 990 & 6.912 & 6,98 & 924 & 954 & 85 \\
\hline \multirow[t]{3}{*}{ Sul } & UFPR & 3.408 & 41.701 & 12,24 & $13.119^{*}$ & 3.407 & 348 \\
\hline & UFRGS & 3.701 & 34.430 & 9,30 & 3.593 & 3.596 & 895 \\
\hline & UFSC & 3.168 & 21.777 & 6,87 & 2.835 & 2.835 & 378 \\
\hline \multirow{3}{*}{$\begin{array}{l}\text { Centro } \\
\text { Oeste }\end{array}$} & UNB & 3.116 & 35.226 & 11,30 & 3.049 & 3.046 & 441 \\
\hline & UFMT & 1.887 & 12.065 & 6,39 & $10.252^{*}$ & 1.818 & 143 \\
\hline & UFG & 2.468 & 17.370 & 7,04 & 2.394 & 2.362 & 361 \\
\hline
\end{tabular}

Fonte: MEC/Inep. Sinopse Estatística do Ensino Superior de Graduação - 1996.

* Não há explicação, no documento fonte, da razão desses números serem tão elevados

\subsection{A pós-graduação e a pesquisa}

No final de 1998, a UFG contava com 39 cursos de especialização, 17 de mestrado, um doutorado institucional e dois mestrados interinstitucionais ${ }^{99}$, enquanto aguardava, ainda, parecer da Capes para seis novos mestrados e um doutorado em educação. Por sua vez, no ano letivo de 1999, foram oferecidos 44 cursos de especialização. A UFG foi receptora de

\footnotetext{
99 A UFG apresenta o segundo maior número de mestrados na região Centro-Oeste, ficando atrás da UnB. No entanto, apresenta número insignificante de cursos de doutorado (Ver: www.capes.gov.br, no item perfil da pós-graduação).
} 
quatro mestrados, e dois doutorados interinstitucionais (UFG. Reitoria, 2000).

Segundo informação da PRPPG, em dezembro de 1999, já havia 18 mestrados 100 e um doutorado, com a perspectiva, para dezembro de 2001, de criação de mais três mestrados e seis doutorados. Até 1998, foram defendidas 669 dissertações e 12 teses. No tocante à pesquisa, no final de 1999, foram cadastrados 1050 projetos: 165 da área de Exatas e da Terra, 206 de Biológicas, 74 de Engenharias, 235 de Ciências da Saúde, 167 de Ciências Agrárias, 30 de Ciências Sociais Aplicadas, 122 de Ciências Humanas e 51 de Lingüística, Letras e Artes. Contabilizaram-se também 192 bolsistas de Iniciação Científica, sendo 142 mantidos pelo Conselho Nacional de Desenvolvimento Científico e Tecnológico (CNPq) e 50 pela UFG, dos quais, 99 eram da área de Biológicas e Saúde, 46 de Exatas e Tecnologia e 47 de Humanas e Sociais.

Além disso, no final de 1999, havia 219 docentes afastados para cursar pós-graduação, sendo 32 em cursos de mestrado e 187 em cursos de doutorado. Esses números não incluem os docentes que faziam mestrado e doutorado, sem afastamento da UFG. Do total, 138 tinham bolsa Programa Institucional de Capacitação Docente (PICDT) - Convênio Capes/UFG. A quota de Bolsas PICDT/Capes 1999 foi de 37 bolsas de doutorado e seis de mestrado. Nos cursos de pós-graduação stricto sensu da UFG, 171 alunos eram bolsistas, sendo 125 da Capes, 15 do CNPq, 15 da Fundação de Apoio à Pesquisa (Funap) e 16 da UFG.

Os indicadores acadêmicos da UFG demonstram que a pós-graduação stricto sensu $u^{101}$ adquiriu maior relevo, a partir da segunda metade da década de 90, quando se observa um crescimento considerável na maioria dos

\footnotetext{
100 A Capes aprovou, para o ano 2000, o Mestrado Profissionalizante em Radiologia Bucomaxilofacial, da Faculdade de Odontologia da UFG.

101 A coleta de dados sobre a pós-graduação e a pesquisa na UFG ocorreu de um modo bastante singular. Realizou-se estudo sobre a evolução da pós-graduação e da pesquisa, com apoio da PRPPG, objetivando atender, também, ao interesse daquela Pró-Reitoria.
} 
indicadores acadêmicos. A UFG chegou ao final dessa década com 17 mestrados credenciados pela Capes e apenas um doutorado, que ainda se encontra em processo de credenciamento ${ }^{102}$. Os programas estão distribuídos em oito áreas de conhecimento ${ }^{103}$, da seguinte forma:

a) três na área de Ciências Exatas e da Terra (Matemática, Química e Física);

b) um na área de Ciências Biológicas (Biologia);

c) dois na área de Engenharias (Engenharia Civil e Engenharia Elétrica e da Computação);

d) um na área de Ciências da Saúde (Medicina Tropical);

e) dois na área de Ciências Agrárias (Agronomia e Medicina Veterinária);

f) um na área de Ciências Sociais Aplicadas (Direito);

g) cinco na área de Ciências Humanas (Educação, Filosofia, História, Geografia e Sociologia);

h) dois na área de Lingüística, Letras e Artes (Letras e Música).

$\mathrm{Na}$ década de 90, a maioria dos programas mantiveram o conceito/nota Capes em torno de $C$ ou 3, o que não difere muito das duas décadas anteriores (tabela 8), dado que não é muito animador, uma vez que parece indicar certa estagnação em termos de melhoria no desempenho dos cursos $^{104}$. Parece ainda indicar que, até o momento, não houve investimento necessário para mudar esses conceitos quase cristalizados, com o objetivo de elevá-los a um patamar de excelência acadêmica ${ }^{105}$, levando a concluir que,

\footnotetext{
${ }^{102}$ A expansão da pós-graduação stricto sensu na UFG enfatizou a criação de cursos de mestrado, em detrimento da consolidação dos programas existentes mediante a criação de doutorados.

103 Utilizou-se a classificação do CNPq para fazer a distribuição dos programas por área de conhecimento.

104 O Programa de Pós-graduação em Educação parece diferir da situação dos demais programas, uma vez que sua conceituação vem crescendo, paulatinamente, a partir de 1996. 105 É preciso salientar, no entanto, que há fatores externos que também condicionam esses conceitos como: o prestígio da universidade e das áreas específicas nos diferentes fóruns e comissões, a política de centralização da pós-graduação stricto sensu e da pesquisa no país, a ausência de uma politica de investimento para corrigir os desequilíbrios regionais.
} 
apesar de a pós-graduação ter quase trinta anos de existência na UFG, ainda não está consolidada em termos de excelência, especialmente quando comparada ao quadro nacional.

Tabela 8 - Programas de pós-graduação strito sensu, conforme data de criação, nível e conceito CAPES 1994-1999

\begin{tabular}{|l|l|c|c|c|c|c|}
\hline No & \multicolumn{1}{|c}{ Programa } & $\begin{array}{c}\text { Ano de Criação do } \\
\text { Curso }\end{array}$ & Nível & $\begin{array}{c}\text { Conceito } \\
\mathbf{9 4 / 9 5}\end{array}$ & $\begin{array}{c}\text { Conceito } \\
\mathbf{9 6 / 9 7}\end{array}$ & $\begin{array}{c}\text { Conceito } \\
\mathbf{9 8 / 9 9}\end{array}$ \\
\hline 01 & Agronomia & 1985 & M/D & B & C & 3 \\
02 & Biologia & 1980 & M & C & C+ & 3 \\
\hline 03 & Direito & 1995 & M & C & C & 3 \\
04 & Educação & 1985 & M & C & B- & 4 \\
\hline 05 & Engenharia Civil & 1996 & M & - & - & 3 \\
06 & Eng. Elét. e de Comp. & 1998 & M & - & - & 3 \\
07 & Filosofia & 1993 & M & - & C & 3 \\
08 & Física & 1992 & M & - & - & 3 \\
09 & Geografia & 1995 & M & - & - & 4 \\
10 & História & 1974 & M & C & C & 3 \\
\hline 11 & Letras & 1972 & M & C & C- & 3 \\
12 & Matemática & 1973 & M & C & C & 3 \\
\hline 13 & Medicina Tropical & 1976 & M & - & B & 3 \\
14 & Medicina Veterinária & 1995 & M & - & - & 3 \\
\hline 15 & Artes (Música) & 1994 & M & - & - & - \\
16 & Sociologia & 1999 & M & - & - & CN \\
\hline 17 & Química & 1998 & M & - & - & CN \\
\hline
\end{tabular}

$\mathrm{CN}$ - Curso Novo

Fonte: Dados obtidos em diversos documentos da UFG.

Na segunda metade da década de 90 ocorreu uma melhora considerável, embora não constante, nos indicadores acadêmicos dos programas. Todavia, não é possível dizer se o crescimento deve-se a um esforço interno de organização dos programas, o que leva a supor que esses tendem a melhorar sua performance, nos padrões da Capes, ou simplesmente representam uma resposta momentânea às agências de fomento, cujos critérios de avaliação tornam-se mais exigentes.

Os indicadores acadêmicos da pós-graduação stricto sensu revelam necessidade de continuar ampliando a produção e a difusão acadêmica, de 
manter um fluxo regular na oferta de vagas, nas matrículas e na titulação discente e de produzir uma estrutura curricular mais compativel com a exigência de pesquisas docente e discente. Além disso, verifica-se que não houve uma valorização significativa da pós-graduação stricto sensu e da pesquisa na instituição que criasse condições de trabalho adequadas para o corpo docente e o discente.

A análise da situação da pós-graduação e da pesquisa revelam, ainda, a necessidade de:

a) sistema unificado de controle acadêmico da pós-graduação;

b) ampliação qualificada do corpo docente permanente dos programas e a conseqüente valorização estratégica de suas atividades de pesquisa e orientação, especialmente nas unidades acadêmicas;

c) lidar adequadamente com o quadro de docentes dos programas e com a incorporação dos recém-doutores, sem prejuízo para os cursos;

d) enfrentar o problema da crescente limitação das bolsas discentes, bem como dos poucos recursos existentes para manutenção e, principalmente, para expansão dos programas;

e) fazer crescer a produção acadêmica docente e discente na maioria dos programas, criando mecanismos mais efetivos de estímulo à produção e de apoio à divulgação dos resultados;

f) ampliar a interdisciplinariedade e a integração entre os programas;

g) repensar a organização dos programas em termos da construção permanente de uma série histórica contendo os principais indicadores acadêmicos;

h) formular diretrizes e estratégias que configurem um projeto comum de ação na área. 


\section{Sinais do processo de metamorfose institucional}

As alterações e as mudanças que ocorrem na UFG, sobretudo a partir do início da década de 90, apontam o fato de que ela passa por um processo de metamorfose, que implica modernização da sua estrutura e da sua organização acadêmica, bem como por uma dinâmica própria de reconfiguração do seu perfil e identidade institucionais. $\mathrm{Na}$ mesma direção, observa-se ainda esforço com a finalidade de ampliar vínculos com a sociedade, especialmente a local, e a instalação de uma cultura de trabalho mais dinâmica e flexivel, apesar de mais controladora do desempenho e da produtividade ${ }^{106}$.

Esse empreendimento, embora apresente razões próprias e contextualizadas, em cada reitorado parece vincular-se, atualmente, à idéia de maior inserção e integração da universidade ao processo de globalização, bem como à redefinição da identidade institucional. A análise preliminar das principais politicas, medidas e ações indicam que ocontecem mudanças significativas na organização interna e nos padrões de gestão, nos processos de informação e avaliação institucional, no modo de integração regional e local, na captação e aplicação de recursos financeiros, nas formas de organização e produção do conhecimento e na definição dos perfis profissionais dos cursos de graduação.

Algumas das alterações e mudanças mais significativas que evidenciam o caso UFG, tornando-o típico do processo de metamorfose das universidades federais, podem ser visualizadas no anexo 5 107. A maior parte das medidas de alteração e de inovação na UFG podem ser agrupadas de acordo com as variáveis consideradas fundamentais neste estudo: gestão, avaliação,

\footnotetext{
$106 \mathrm{O}$ estudo sobre os efeitos da GED na gestão e no trabalho acadêmico das Ifes, realizado por Catani e Oliveira (1999a) com base em observações sistemáticas da implementação dessa gratificação na UFG, exemplifica a sua nova postura institucional.

107 Nosso interesse é, apenas, apontar aspectos que demonstrem a especificidade do caso UFG, sem a intenção de fazer uma análise pormenorizada das medidas de alteração, uma vez que parte delas são estudadas no Capítulo III.
} 
financiamento, currículo, pesquisa e pós-graduação ${ }^{108}$. Esses elementos são, em geral, organizadores do tempo-espaço do trabalho acadêmico na universidade. As alterações e mudanças inovadoras nessas áreas de trabalho perpassam mais de um reitorado, dizendo respeito ao periodo 1989-1999. Na prática, elas se interligam e se determinam de diferentes modos.

As medidas e as ações mais significativas nas variáveis consideradas parecem indicar, de um modo geral, que há um empreendimento contínuo com o fim de estabelecer modelos, sistemas e processos de avaliação que impliquem em maior conhecimento e controle na produção acadêmica ${ }^{109}$, o que parece significar, também, mudança na cultura organizacional, objetivando maior eficiência e produtividade. Não se observam, no período considerado, rupturas ou grandes alterações nos rumos da universidade que mudem esse empreendimento institucional. A UFG parece, atualmente, uma instituição modelada e organizada por critérios técnico-acadêmicos de grande relevância, especialmente para um gerenciamento mais ágil e eficaz.

Considerando, especificamente, as variáveis do estudo, observa-se que as medidas e as ações dirigem-se para:

a) constituição de sistema de informações que permita qualificar a gestão e racionalizar o uso dos recursos disponíveis, objetivando ampliar a eficiência e estimular a produtividade;

b) organização e o estabelecimento de processos de aperfeiçoamento dos mecanismos de avaliação e controle do trabalho acadêmico, que conduzam à avaliação institucional permanente;

\footnotetext{
108 Sabe-se que esses elementos não esgotam a totalidade das medidas e dos processos em andamento no interior da instituição. Uma área, por exemplo, de grande importância atualmente, é o da extensão e prestação de serviços. Muitas inovações e mudanças de comportamento na instituição advêm dessa área.

109 O estabelecimento de sistemas não parece uma ação específica da UFG, embora essa universidade seja considerada pioneira na criação de vários modelos. O MEC também vem encaminhando ações na direção da modelagem das Ifes. Só para exemplificar, em 1994, o MEC lançou o Sistema de Atividades Docentes das Ifes, o Sistema de Administração de Patrimônio das Ifes e o Sistema de Apuração de Custos das Ifes. Já em 1996, lançou o Sistema de Acompanhamento Acadêmico das Ifes.
} 
c) modernização da infra-estrutura fisica e de equipamentos, bem como da organização acadêmica;

d) flexibilização institucional, mediante criação de fundações, que dêem maior agilidade administrativa e financeira, além de permitir maior relacionamento e vínculos da universidade com a comunidade e com o setor produtivo;

e) movimentação curricular objetivando flexibilizar os currículos e adequar a formação acadêmica às novas demandas e exigências profissionais;

f) criação de uma estrutura mais ampla de apoio, acompanhamento, avaliação e controle da pesquisa e pós-graduação na instituição;

g) definição de áreas prioritárias para a pesquisa, ligadas ao contexto local e desenvolvimento do Estado. 


\section{CAPÍTULO III}

\section{DESVELANDO O PROCESSO DE METAMORFOSE DA UNIVERSIDADE FEDERAL DE GOIÁS (UFG): o campo e sua produção}

O propósito geral deste capitulo é apresentar os efeitos da reestruturação da educação superior na produção do trabalho acadêmico na UFG, especialmente nos padrões de organização e gestão da universidade. Para tanto, pretende atingir dois objetivos: desvelar o processo de metamorfose institucional, com base nos movimentos de gestão, financiamento, avaliação, currículo, pesquisa e pós-graduação; evidenciar a dialética existente nas ações e reações presentes nos processos ou movimentos de adaptação, resistência, improvisação ou inovação. O foco central da análise do processo de metamorfose institucional é, portanto, o campo e sua produção, evidenciado em alguns dos elementos considerados fundamentais na organização do tempo-espaço do trabalho na universidade, como revela o caso em estudo.

\section{O movimento na área de gestão e financiamento}

Na UFG, atualmente, é quase impossivel separar o movimento de gestão do movimento de financiamento da instituição, o que ocorre, em grande parte, porque, na reforma da educação superior, esses movimentos estão imbricados e se determinam mutuamente, razão por que, nesta exposição, serão considerados em seu conjunto. A análise dos dados permite afirmar, no entanto, que o movimento de gestão é mais condicionado pelo movimento de financiamento, devendo-se, externamente, à certa racionalidade financeira que impera no processo de definição e de tomada de posição, no tocante às políticas de educação superior, bem como a uma 
progressiva limitação de recursos financeiros e humanos. A situação agravase a cada ano, em decorrência da crise econômica e da política restritiva adotada pelo governo em relação às Instituições Federais de Ensino Superior (Ifes), de um modo geral.

\subsection{A questão do orçamento: histórico e perspectivas}

No caso da UFG, nos últimos anos, a questão financeira intensifica-se por causa da insuficiência de recursos orçamentários oriundos do Tesouro. As restrições ocorrem sobretudo nos recursos destinados à manutenção e ao investimento, em razão dos cortes feitos em particular pela área econômica do governo. O relatório da gestão 1994-1997 (UFG. Reitoria, 1998c) aponta situações graves como: a escassez de dotação orçamentária inicial a cada ano; a luta para conseguir suplementação e a demora em se obter recursos; a irregularidade do fluxo dos recursos financeiros; a instabilidade da ordem jurídica com a edição de decretos e medidas provisórias. Essas situações são amplamente exemplificadas nos exercícios orçamentários da instituição, no entanto, basta citar quatro dentre as que ocorreram no período: a) a cada ano caem os recursos, especialmente para custeio; b) os recursos repassados para a UFG, nos últimos anos, já chegaram a corresponder a $70 \%$ dos recursos orçados; c) além do orçamento não ser respeitado, em 1996, a proposta orçamentária da UFG foi elaborada pelo MEC, sem a participação da universidade; d) a partir de 1995, a folha de pagamento da UFG foi inserida no Sistema Integrado de Administração de Pessoal (Siape), do governo federal, por determinação do então Ministério da Administração e Reforma do Estado (Mare), assim como ocorreu com todas as Ifes.

A posição do orçamento operativo da UFG, para o exercício de 1998, permite evidenciar, com mais propriedade, as condições de funcionamento da universidade. Nesse ano, do montante orçado para a UFG, houve um corte de 
$\mathrm{R} \$$ 4.108.432,09110, como mostra a tabela 9, de cujo contingenciamento, $78 \%$ ocorreram nos recursos de custeio, $20 \%$ nos de capital e $2 \%$ nos de pessoal, o que espelha uma situação bastante grave, uma vez que os recursos não foram suficientes para pagamento das despesas e dividas de 1998, nem para aquelas acumuladas em anos anteriores ${ }^{111}$. Para se ter uma idéia, a divida de 1998, repassada para 1999, ficou em mais de $R \$$ 1.000,000,00 (UFG. Proad, 1999c) ${ }^{112}$.

Tabela 9 - Orçamento da UFG 1998

\begin{tabular}{|c|c|c|}
\hline Receita & Execução & Diferença \\
\hline $153.301 .515,00$ & $149.193 .082,91$ & $4.108 .432,09$ \\
\hline
\end{tabular}

Fonte: UFG. Proad. Relatório de prestação de contas da UFG. Exercício 1998.

Do total dos recursos executados em 1998 (tabela 10), 75\% foram utilizados para pagamento de pessoal (ativos e inativos); 5\% para custeio da folha de pessoal (Professor Substituto, Auxílio Creche, Residência Médica, Vale Transporte e Auxílio Alimentação); 2\% para custeio de bolsas; $15 \%$ para custeio/manutenção; $1 \%$ para custeio/exercício anterior; e $2 \%$ para equipamentos/obras.

\footnotetext{
110 Cortes nos orçamentos das Ifes ocorreram por meio do Decreto oㅡ 2.773/98, publicado no Diário Oficial da União (DOU), de 9 de setembro de 1998.

111 A Pró-Reitora de Administração e Finanças, em maio de 1999, apontou graves problemas enfrentados pela UFG, como a falta de recursos adequados para a manutenção básica, para as despesas acadêmicas e administrativas, para o programa de bolsas de graduação e pósgraduação e para recuperação das instalações físicas. Além disso, a universidade não podia contar com recursos para expansão, ou seja, para investimentos e construção de novos prédios (Moreira, 1999).

112 Situação comum na maioria das Ifes. A Universidade Federal do Rio de Janeiro (UFRJ) possui uma dívida acumulada com fornecedores de água, luz, telefone, serviços de limpeza e segurança etc., desde 1996, no valor de R\$ 22 milhões (SBPC. Jornal da Ciência. 30 abr. 1999). A Universidade Federal do Ceará (UFC) tem um débito com precatórios, a ser pago no ano 2000, cujo montante chega a R\$ 112, 03 milhões (Folha de S. Paulo. 7 fev. 2000, p. 5).
} 
Tabela 10 - Execução do orçamento da UFG - 1998

\begin{tabular}{|c|c|c|c|c|c|}
\hline $\begin{array}{c}\text { Pessoal } \\
\text { (Ativo e } \\
\text { Inativo) }\end{array}$ & $\begin{array}{c}\text { Custeio Folha } \\
\text { Pessoal }\end{array}$ & $\begin{array}{c}\text { Custeio } \\
\text { Bolsas }\end{array}$ & $\begin{array}{c}\text { Custeio } \\
\text { Manutenção }\end{array}$ & $\begin{array}{c}\text { Custeio Exerc. } \\
\text { Anterior }\end{array}$ & $\begin{array}{c}\text { Capital } \\
\text { (Obras/ } \\
\text { Equip.) }\end{array}$ \\
\hline $\begin{array}{c}114.166 .363,07 \\
(75 \%)\end{array}$ & $\begin{array}{c}7.417 .880,79 \\
(5 \%)\end{array}$ & $\begin{array}{c}3.806 .352,59 \\
(2 \%)\end{array}$ & $\begin{array}{c}23.066 .901,63 \\
(15 \%)\end{array}$ & $\begin{array}{c}2.229 .490,63 \\
(1 \%)\end{array}$ & $\begin{array}{c}2.396 .562,82 \\
(2 \%)\end{array}$ \\
\hline
\end{tabular}

Fonte: UFG. Proad. Relatório de prestação de contas da UFG. Exercício 1998.

No período 1994-1997, a execução da despesa com os recursos próprios e oriundos do Tesouro atingiu o total de $\mathrm{R} \$ 456.805 .167,00^{113}$. Em 1998, o montante foi de $\mathrm{R} \$ 153.083 .551,53$. A média percentual dos recursos, no periodo 1994-1997, destinados a pessoal foi maior que em 1998 (tabela 11). Todavia, ocorreu aumento dos recursos para o custeio e diminuição dos de capital. Em grande parte, em razão dos recursos obtidos por meio de convênios e receita própria, que se tornaram cada vez mais importantes para a manutenção e desenvolvimento da instituição.

Tabela 11 - UFG: execução orçamentária e financeira com pessoal, custeio e capital no período 1994-1997 e no ano de 1998

\begin{tabular}{|c|c|c|c|}
\hline Período & Pessoal & Custeio & Capital \\
\hline $1994-1997$ & $362.381 .277,00$ & $80.299 .650,00$ & $14.074 .240,00$ \\
& $(79 \%)$ & $(18 \%)$ & $(3 \%)$ \\
\hline \multirow{2}{*}{1998} & $114.166 .363,07$ & $36.520 .625,58$ & $2.396 .562,82$ \\
& $(75 \%)$ & $(23 \%)$ & $(2 \%)$ \\
\hline
\end{tabular}

Fontes: UFG. Reitoria. Relatório de gestão 1994-1997;

UFG. Proad. Relatório de prestação de contas da UFG. Exercício 1998.

A comparação anterior não significa que a diminuição dos recursos com pessoal deva ser tomada como uma tendência, não obstante a crescente diminuição do contingente de professores na ativa. A tabela 12 mostra que

113 O montante de recursos orçados para o exercício financeiro de 1997 (UFG. Resolução ECU/CCEP/CC no 1/97) foi de R\$ 142.204.854,00 o que não significa que a execução da despesa tenha atingido esse valor. 
em 1998 a despesa com pessoal foi 8,14\% maior que o ano anterior, em boa parte, em razão da GED. O percentual de aumento foi mais significativo, na folha dos Pensionistas Civis, Outros Benefícios e Vencimentos, Salários e Vantagens. Na UFG, a execução orçamentária com pessoal em 1998, registrou a seguinte distribuição percentual: Ativos (56\%), Inativos $(38 \%)^{114}$, Outros Beneficios (4\%), Precatórios e outros (2\%)(UFG. Proad, 1999c). Os gastos com aposentados e pensionistas oneram sobremodo a folha da universidade, razão pela qual a administração superior da UFG (e da Andifes, em geral) entende que essa despesa deva ser repassada para a Previdência e os recursos utilizados, em boa medida, para investimento. Essa solução é uma bandeira na discussão do modelo de autonomia universitária, atualmente em debate.

Tabela 12 - UFG: despesa com pessoal em 1997 e 1998

\begin{tabular}{|l|c|c|c|}
\hline \multicolumn{1}{|c|}{ Discriminação } & Exercício 1997 & Exercício 1998 & Variação \\
\hline Pessoal Civil (Estatut./CLT) & $55.852 .579,66$ & $61.305 .132,20$ & 9,76 \\
Vencimentos, Salários e Vantagens & $51.160 .791,14$ & $56.583 .746,29$ & 10,60 \\
13ํㅡㄴ Salário & $4.691 .788,52$ & $4.721 .385,91$ & 0,63 \\
Outros Benefícios & $9.691 .633,32$ & 8.451 .382 .02 & 12,80 \\
Inativos Civis & $36.992 .619,73$ & $40.569 .519,92$ & 9,67 \\
Pensionistas Civis & $3.035 .404,69$ & $3.840 .328,93$ & 26,52 \\
\hline Total da Despesa & $\mathbf{1 0 5 . 5 7 2 . 2 3 7 , 4 0}$ & $\mathbf{1 1 4 . 1 6 6 . 3 6 3 , 0 7}$ & $\mathbf{8 , 1 4 \%}$ \\
\hline
\end{tabular}

Fonte: UFG. Proad. Relatório de prestação de contas da UFG. Exercício 1998.

A situação, em 1999, foi ainda pior. Para o exercício financeiro de 1999, a UFG teve sua receita financeira estipulada em $\mathrm{R} \$ 140.791 .292,00$, sendo R\$ 17.368.000,00 (14\%) oriundos de recursos próprios (UFG. Resolução Consuni/Cepec/CC no 1/98), porém, esse montante foi rebaixado

114 Em 31 de dezembro de 1997, havia 1.571 inativos, número que em 31 de dezembro de 1998 subiu para 1.612, ocorrendo um crescimento de quase 4\%. O número de pensionistas, de 191 passou para 210, aumentando quase 10\% (UFG. Proad, 1998: 106-107). 
pelo MEC para cerca de $R \$ 130$ milhões. Essa diminuição ocorreu porque o Hospital Universitário deixou de participar do orçamento, passando a ser responsabilidade do Ministério da Saúde. Os recursos, antes destinados ao Hospital, foram transferidos, pelo MEC, para o Fundo de Manutenção do Ensino Fundamental e Valorização do Magistério, evidenciando a prioridade do governo. Conforme cálculos, cerca de 94\% desses $\mathrm{R} \$ 130$ milhões estavam comprometidos com o pagamento de pessoal (UFG. Proad, 1999a) ${ }^{115}$.

Além dessa situação, os recursos para custeio, em 1999, por determinação do governo federal, foram diminuídos em 15\%. Se em 1998 esses recursos não foram suficientes, sobretudo em razão dos cortes orçamentários de verbas para custeio, em 1999, o problema tornou-se ainda mais grave, uma vez que restavam as dividas do ano anterior. Também, em razão dos cortes, não havia dotação para investimento. Ainda por determinação do MEC, o orçamento de 1999 foi liberado por meio de programações trimestrais, na forma de duodécimos orçamentários, segundo arrecadação da União. Essa situação demonstra que o orçamento está sendo feito sem atender às necessidades básicas da instituição ${ }^{116}$.

Há atualmente grande empenho em reverter o quadro de limitação dos recursos orçamentários destinados à UFG. Exemplo da luta foi a Carta à Sociedade, encaminhada pela Reitoria da universidade, amplamente divulgada no final de 1998, em que expõe a situação da instituição e conclama os segmentos políticos, empresariais e culturais para efetiva participação na defesa da UFG, sugerindo as seguintes medidas essenciais:

a) Apresentação de emendas no Congresso com vistas à retirada dos cortes realizados no orçamento de 1999 para as Ifes; b) Suplementação orçamentária para viabilizar dívidas das Ifes referentes aos exercícios de

\footnotetext{
115 A proposta orçamentária da UFG, para o exercício de 2000, foi estimada em $R \$$ 145.180.928,00. "Os recursos foram alocados nos diversos programas a partir de um teto estabelecido pelo MEC para Pessoal e Encargos Sociais, Beneficios e para as atividades de Manutenção da Instituição" (UFG. Proad, 1999a).

116 Declaração da Pró-Reitora de Administração e Finanças por ocasião da Reitoria Itinerante, realizada na Faculdade de Educação, em 15 de abril de 1999.
} 
1997 e 1998; c) Alocação de recursos para a pesquisa; d) Autorização para realização de concurso público das 121 vagas de docentes distribuídas para a UFG pelo MEC, assim como daquelas referentes aos técnicoadministrativos; e) Quanto aos Campi de Jataí, Catalão, Rialma e Goiás, os docentes são contratados pela Prefeitura dos Municípios citados, segundo termo de convênio celebrado com esta Instituição; no entanto, diante das dificuldades enfrentadas pelos Municípios na manutenção do quadro docente, há a imperiosa necessidade de que as vagas correspondentes, no total de 210, sejam liberadas pelo MEC para a UFG; f) Expansão do ensino público, especialmente, por intermédio do aumento de vagas, da oferta de novos cursos e cursos noturnos, somente possiveis com a consecução das providências de apoio, com destaque para verbas orçamentárias e construção dos prédios (Unidades Acadêmicas e Órgãos) e laboratórios; e g) ações parlamentares constantemente voltadas à defesa da Universidade Federal de Goiás (UFG. Reitoria, 1998a)

Carta semelhante foi encaminhada à comunidade universitária, em abril de 1999, na qual a Reitoria lembra que a UFG

vivencia momento de discussões com o Poder Público e a sociedade acerca dos seus valores e fins institucionais, situação compreendida no amplo $e$ irrestrito quadro das Ifes e determinante dos novos rumos do sistema de ensino superior (UFG. Reitoria, 1999a).

\title{
Para a Reitoria,
}

\begin{abstract}
o presente exige, de cada um (...), atitudes de valorização e de crescimento da Universidade Pública, Gratuita e de Qualidade, concretizadas no esforço individual, que, coletivamente, permitirá à sociedade antever a necessidade inolvidável da manutenção e da oferta das condições de aperfeiçoamento da UFG (...). O ano de 1999 constituirá marco importante no estabelecimento dos parâmetros futuros das Ifes (UFG. Reitoria, 1999a) ${ }^{117}$.
\end{abstract}

De um modo geral, a situação orçamentária da UFG insere-se em um quadro mais amplo de "diminuição da participação das Ifes, nos recursos orçamentários e financeiros da união" (Moreira, 2000: 10), uma vez que, em termos percentuais, verifica-se "que os valores saem de 2,2\% em 1994 para 1,8\% em 1999" (p. 9). De um modo geral, em termos do Produto Interno

\footnotetext{
${ }^{117}$ Segundo Otom Anselmo de Oliveira, Reitor da UFRN, a situação orçamentária leva as Ifes a buscarem alguns recursos adicionais nos programas especiais, bem como mobiliza os reitores para aprovação de emendas com recursos suplementares (SBPC. Jornal da Ciência. 11 fev. 2000, p. 2).
} 
Bruto (PIB), verifica-se decréscimos acentuados nos recursos aplicados na educação no Brasil. De acordo com o orçamento do tesouro, os recursos "passaram de um índice de 1,1\% em 1995 para 0,5\% em 1999, relativo ao PIB brasileiro" (p. 8) ${ }^{118}$.

\subsection{Alterações no padrão de gestão e financiamento}

A grave situação orçamentária da universidade é, em grande parte, determinante do movimento de gestão e financiamento, contribuindo significativamente para a intensificação do processo de metamorfose institucional. As alterações mais importantes podem ser agrupadas em três processos ou movimentos básicos: interação universidade-sociedade e a ampliação da receita própria; problemática dos convênios e contratos; questão da prestação de serviços remunerados e dos cursos de especialização.

\subsubsection{A interação universidade-sociedade e a ampliação da receita própria}

De um modo geral, os alertas e a luta pela manutenção e ampliação dos recursos advindos do Tesouro não obtiveram êxito satisfatório. Por isso, a diminuição dos recursos para a manutenção e investimento leva a universidade a improvisar ou buscar alternativas de solução para manter o funcionamento da instituição, cujo processo é, em geral, permeado de tensões, conflitos e desafios, o que se revela, sobretudo, nos colegiados de decisão da instituição, em que ocorrem defesas ou críticas quanto à nova cara que a UFG vem apresentando. As críticas são rebatidas, em geral, com a argumentação de que: as pessoas desconhecem a situação financeira da instituição; é preciso ampliar o relacionamento com a sociedade, já que a

118 A esse respeito consultar: Moreira, 2000; Amaral, 1998; USP. IEA, 2000. 
universidade não é uma ilha; é necessário compreender o que se faz e porque se faz, ou seja, o que está sendo feito para salvar a universidade ${ }^{11}$.

A interação universidade-sociedade é colocada como bandeira fundamental para superação da crise atual. É claro que há diferentes entendimentos, especialmente entre os segmentos organizados da comunidade acadêmica, a respeito dessa interação, a qual a Reitoria defende tomando medidas concretas para que ela ocorra. De um lado, procura levar a UFG a participar mais efetivamente dos movimentos sociais e dos problemas da sociedade local e regional. De outro, amplia a visibilidade da produção acadêmica da instituição, mostrando sobretudo seu progresso e suas potencialidades para o desenvolvimento local e regional. São dois os exemplos nessa direção: a inserção, no jornal Diário da Manhã (jornal de Goiânia, com a segunda maior tiragem), de um caderno dominical sobre a Universidade, e a criação, no Shopping Goiânia (segundo maior shopping da cidade) da loja Mercado Acadêmico, administrada pela Funap/UFG, que comercializa produtos da instituição, como livros, CDs, cartões, roupas, doces e conservas, cosméticos etc.

A maior interação universidade-sociedade representa realmente uma necessidade para a instituição, especialmente por duas razões. A primeira diz respeito à necessidade de conquistar maior legitimidade social, ganhando a simpatia e o apoio da sociedade na luta em prol da universidade pública e gratuita. A segunda refere-se à busca de formas alternativas de sobrevivência institucional, que passa pela questão dos recursos para manutenção e investimento. Nesse sentido, verifica-se que crescem na universidade o empenho, a movimentação e a angústia de gestores, e mesmo de docentes, em torno da necessidade de ampliação da receita própria da instituição. $O$ desafio colocado pela Pró-Reitoria de Administração e Finanças, ao final do

119 Para se ter uma idéia do tamanho da crise, em reunião da Reitoria Itinerante, realizada em abril de 1999, na Faculdade de Educação, a Pró-Reitora de Administração e Finanças da UFG informou que, até aquela data, ainda não havia pago as contas de água e luz vencidas 
exercício de 1998, é o de "buscar o crescimento da instituição, apesar da escassez dos recursos orçamentários-financeiros" (UFG. Reitoria, 1999b). Reconhece-se a importância de continuar lutando pelos recursos federais ${ }^{120}$, mas também a necessidade de "buscar caminhos alternativos"121. Nesse sentido, afirma-se que as "parcerias institucionais e com os vários setores da sociedade tornam-se condições básicas de viabilização da universidade para o próximo século" (UFG. Proad, 1999a).

O empenho da universidade para aumentar a receita própria coadunase com o empreendimento ou com o que parece ser a atual política do MEC, ou seja, limitar recursos para custeio, como mostra a tabela 13 . Na universidade, verifica-se que as despesas com recursos oriundos de convênios celebrados entre UFG e outras entidades federais, que também têm suas informações contábeis registradas no Sistema de Administração Financeira do Governo Federal (Siafi), diminuíram ano a ano, especialmente em 1998. O diferencial dos recursos para custeio provém de recursos Próprios, ou seja, gerados pela própria instituição, os quais, todavia, são bastante irregulares. Os recursos do Tesouro praticamente mantiveram-se nos últimos anos, apesar do aumento das despesas de custeio e a desvalorização do real122.

desde maio de 1998. Informou também que 24 Ifes viviam situação semelhante e apenas cinco estavam com as contas em dia, enquanto as demais não informaram.

120 Em reunião da Reitoria Itinerante, ocorrida na Faculdade de Educação, no dia 15 de abril de 1999, a Reitora informou que a maior preocupação, no momento, era a autonomia universitária. Segundo ela, essa questão, na UFG, envolve quatro aspectos fundamentais: o repasse de recursos suficientes para pagar as contas atrasadas (água, luz, telefone etc.), manter a universidade funcionando e investir na modernização e expansão; a garantia dos direitos dos aposentados, embora reconheça que o pagamento dos aposentados consome boa parte dos recursos orçamentários; o quadro de recursos humanos docentes, que apresenta 122 vagas aguardando concurso; a ausência de recursos para pagamento dos precatórios.

121 Comentário feito em Reunião do Conselho de Curadores, realizada em 24 de março de 1999.

122 Os recursos de Convênio são aqueles oriundos de convênios celebrados com outras Entidades Federais que também se utilizam do Sistema de Administração Financeira do Governo Federal (Siafi). Recursos Próprios são aqueles arrecadados diretamente pela UFG, mesmo convênios com Entidades não-integrantes do Siafi. Recursos do Tesouro são aqueles oriundos das receitas do Tesouro Nacional, repassadas ao MEC. 
Tabela 13 - UFG: total das despesas com custeio na execução orçamentária de 1996 a 1998

\begin{tabular}{|c|c|c|c|}
\hline $\begin{array}{c}\text { Origem dos } \\
\text { Recursos }\end{array}$ & $\mathbf{1 9 9 6}$ & $\mathbf{1 9 9 7}$ & $\mathbf{1 9 9 8}$ \\
\hline Convênios & $5.088 .259,04$ & $4.731 .900,13$ & $3.999,968,62$ \\
\hline Próprios & $12.391 .183,70$ & $20.972 .278,36$ & $5.878 .225,39$ \\
\hline Tesouro & $14.791 .511,03$ & $14.891 .945,54$ & $14.943 .379,00$ \\
\hline Total & $\mathbf{3 2 . 2 7 0 . 9 5 3 , 7 7}$ & $\mathbf{4 0 . 5 9 6 . 1 2 4 , 0 3}$ & $\mathbf{2 4 . 8 2 1 . 9 7 3 , 0 1}$ \\
\hline
\end{tabular}

Fonte: Brasil. MEC/Subsecretaria de Planejamento e Orçamento. ( www.mec.gov.br)

A indução do MEC para que as Ifes ampliem os recursos próprios, em razão do próprio instinto de sobrevivência institucional, tem obtido êxito ${ }^{123}$. A UFG encontrou como forma de manutenção e de investimento em equipamentos, de reformas e de ampliação da área física, mecanismos que contribuem para otimizar e/ou aumentar a receita própria da universidade. Dentre os caminhos alternativos mais evidenciados aparecem: o enxugamento de estruturas administrativas ${ }^{124}$; a contenção de despesas ${ }^{125}$; a otimização dos recursos existentes; a priorização de atividades, especialmente ligadas ao ensino; a utilização das potencialidades existentes na instituição na geração de receita própria, sobretudo por meio da prestação

\footnotetext{
123 Nesse sentido, a Universidade de Brasília (UnB) é mostrada como exemplo de sucesso. Segundo matéria da revista Isto é, de 25 janeiro de 2000, a UnB, a $n^{\circ} 1$ do Brasil, de acordo com o "Provão, é hoje uma fórmula de sucesso" porque conseguiu aliar "qualificação $e$ criatividade gerencial", conseguindo cobrir $25 \%$ de seus gastos com recursos próprios obtidos por meio de convênios, parcerias e prestação de serviços, em geral.

124 Um exemplo significativo desse enxugamento foi a extinção dos departamentos da universidade ocorrida no dia 21 de dezembro de 1999, em reunião do Consuni. Em razão da falta de Função Gratificada (FG-1), para pagar os coordenadores de cursos que estavam sendo criados, a solução administrativa encontrada, graças a flexibilidade regimental, foi propor a extinção gradativa dos departamentos, com o fim dos mandatos. No entanto, para alguns membros do Conselho, "os cursos novos estão sendo criados sem um plano de expansão, o que prejudica os cursos já estruturados". Todavia, a Reitora entende que a autonomia possibilitará repensar toda a estrutura da universidade.

125 Segundo dados da Pró-Reitoria de Administração e Finanças (Proad), a contenção de despesas com fotocópias, correios, vigilância, limpeza, publicações etc. acontece, sobretudo, por meio da reavaliação de contratos, terceirização dos serviços e orientação administrativa.
} 
de serviços remunerados e comercialização de produtos acadêmicos. Essas medidas são necessárias para manter o funcionamento da universidade e, também, uma forma de lutar para preservar, pelo menos, a gratuidade nos cursos de graduação e pós-graduação stricto sensu.

\subsubsection{A problemática dos convênios e contratos}

O investimento em equipamentos e em reformas, muitas vezes, dá-se em contrapartida com outras instituições e entidades na execução de convênios. Os recursos executados por convênios são fundamentais na instituição, em que pese também sua limitação e irregularidade ${ }^{126}$. Como se vê na tabela 14, o volume de recursos executados, de 1994 a 1996, mediante convênios, foi extremamente significativo ${ }^{127}$.

Tabela 14 - UFG: recursos executados por convênio no período 1994-1998

\begin{tabular}{|c|c|c|c|c|c|}
\hline 1994 & $\mathbf{1 9 9 5}$ & $\mathbf{1 9 9 6}$ & $\mathbf{1 9 9 7}$ & $\mathbf{1 9 9 8}$ & Total \\
\hline $4.355 .976,03$ & $3.061 .410,10$ & $5.132 .347,84$ & $4.598 .251,84$ & $3.999 .968,62$ & 21.147 .954 .53 \\
\hline
\end{tabular}

Fontes: UFG. Reitoria. Relatório de gestão 1994-1997;

UFG. Proad. Relatório de prestação de contas da UFG. Exercício 1998.

O discurso em prol de uma maior agilização na execução dos convênios e a ampliação da receita própria deram origem, na UFG, a novas fundações ${ }^{128}$. A universidade já conta atualmente com três fundações, duas das quais foram criadas nos últimos anos. A primeira fundação, a Fundação de Apoio à Pesquisa (Funap), criada na década de 80, objetivava apoiar a

\footnotetext{
126 Segundo a Pró-Reitora de Administração e Finanças, "os convênios estão permitindo pagar as contas atrasadas, na medida em que os recursos entram" (UFG. Reunião do Consuni, em 9 de novembro de 1999).

127 Os números da UFG são pouco diferentes daqueles fornecidos pela Subsecretaria de Planejamento e Orçamento do MEC, como se vê na tabela 13.

128 As fundações devem ser credenciadas pelo MEC para poderem prestar serviços à universidade, como prevê a Lei no 8.958/94, conhecida como lei da prestação de serviços.
} 
pesquisa. A Fundação de Apoio ao Hospital das Clinicas (Fundahc), de 1999, tem a finalidade principal apoiar o Hospital Universitário, enquanto a Fundação Rádio e Televisão Educativa e Cultural (RTVE), criada em 1997, a de dar suporte à Rádio e à TV da universidade. Na prática, elas atendem às unidades acadêmicas da UFG na prestação de serviços e viabilização dos convênios, especialmente a primeira. A universidade mantém convênios com essas fundações exatamente para agilizar e viabilizar a prestação de serviços. Faz-se atualmente grande esforço para que não ocorra devolução de recursos de convênio, que são fundamentais para o funcionamento institucional. As auditorias do governo federal não oferecem grandes obstáculos à existência dessas fundações, pelo contrário, parecem incentivar esse modo de gerenciamento dos recursos.

Em geral, há uma grande preocupação com os convênios, evidenciada na crescente importância da comissão de convênios da universidade. Novos trâmites, novos hábitos e novas práticas constituem-se no cotidiano da instituição, em razão dos inúmeros convênios assinados entre a UFG e outras instituições do Estado e do país, boa parte dos quais dizem respeito ao desenvolvimento conjunto de projetos, prestação de serviço da UFG ou, simplesmente, o estabelecimento de condições e possibilidades de trabalhos conjuntos $^{129}$. Para se ter uma idéia do volume de convênios, de janeiro a dezembro de 1999, foram assinados ou renovados quase sessenta convênios, além de vários contratos (anexo 6) ${ }^{130}$, alguns dos quais são fundamentais

\footnotetext{
129 Esses convênios dão destaque à questão financeira, especialmente no que tange às obrigações da UFG, que não aceita, por exemplo, que o seguro trabalho seja obrigação da universidade.

130 Em 1999, a UFG celebrou "convênios/contratos com Companhia Energética Mercosul, Funap/Ápice Telemática Ltda, Secretaria de Planejamento e Desenvolvimento e Secretaria da Educação e Cultura do estado de Goiás, Fundação RTVE, Faeg, Senai e Sinduscon-GO, Fundação José Normanha, Prefeitura de Goiânia, Ministério das Relações Exteriores, Câmara Municipal de Goiânia, Funcad, Prefeitura Municipal de São Luiz de Montes Belos e Firminópolis, Embrapa, Instituto Nacional de Direito Público, UFPR, UERJ, Fundação Cultural Palmares/Funap, Cerne, Universidade Federal do Rio Grande do Norte, Secretaria de Segurança Pública do estado de Goiás, Incra/Funap, Fundação Jaime Câmara, Prefeitura Municipal de Goiás, Secretaria Municipal de Saúde-Goiânia, Fundação Assistencial,
} 
para o funcionamento da instituição, como é o caso do convênio entre UFG e o governo de Goiás, assinado em março de 1999, garantindo que cerca de 210 professores, dos campi de Jataí e Catalão, percebam 70\% dos salários com recursos do tesouro estadual e, apenas, 30\% com recursos das prefeituras dos respectivos municípios, que alegam não ter mais condições de pagar os docentes, como previsto no acordo de criação dos campi avançados.

A universidade está, cada vez mais, aprendendo e profissionalizando a execução de projetos que envolvem recursos externos. Nesse sentido, ela está ordenando, fiscalizando e viabilizando, sobretudo, a parte financeira dos projetos, com a intermediação das fundações, que cobram uma taxa de administração em torno de $10 \%$. As principais dificuldades para viabilização dos projetos são: contratação de pessoal; disponibilização de docentes; custeio pelas unidades acadêmicas ou pela UFG de despesas de materiais básicos; prestação de contas. Em geral, a universidade oferece sua infraestrutura física e equipamentos existentes, bem como o seu corpo de trabalhadores, sem prejuizo das atividades acadêmico-administrativas. As amarras na execução do orçamento da UFG e a ausência de outros recursos e mecanismos flexíveis também dificultam a execução dos projetos ${ }^{131}$.

O aumento no volume de serviços remunerados, sobretudo as consultorias, assessorias, cursos de especialização e de atualização, intensificou-se de modo significativo nos últimos três anos. A procura de alternativas $^{132}$ que gerem recursos já é um empreendimento na maioria das unidades acadêmicas, muitas vezes motivado pela necessidade de arcar com

Educacional e Médico-Social, Transurb, Emater, Universidade Federal do Mato Grosso do Sul" (UFG. Reitoria, 2000, p. 5).

131 As fundações apresentam-se como a solução mais viável para a execução dos projetos. Em geral, os convênios que envolvem recursos financeiros, especialmente sob a forma de prestação de serviços remunerados, incluem uma das fundações credenciadas da universidade, e atualmente a Funap administra a grande maioria desses projetos e serviços. 132 O título Procura de Alternativas foi estampado no Caderno Universidade, publicado pelo jornal Diário da Manhã, em 11 de abril de 1999. A matéria tratava, mais especificamente, de cursos intensivos de computação que eram ofertados para gerar recursos, em razão dos "efeitos da crise econômica e da escassez de verba por conta dos cortes federais". 
as despesas de manutenção e conservação dos equipamentos. Essas pequenas mudanças tornam-se fundamentais na alteração do comportamento docente e na natureza da produção do trabalho acadêmico.

\subsubsection{A prestação de serviços remunerados e os cursos de especialização}

O fato mais marcante do processo de metamorfose deu-se com o início da cobrança de mensalidades nos cursos de especialização, em algumas unidades acadêmicas, o que gerou certo nível de polêmica e de tensão na instituição. Em algumas unidades, a cobrança instalou-se naturalmente, especialmente naquelas que, por natureza, apresentam maior possibilidade de oferta de serviços e produtos de interesse comercial. Quando houve alguma tentativa de reação, a batalha já tinha sido vencida, uma vez que os beneficios dessa nova prática já eram sentidos e também já havia uma nova mentalidade em formação. A reação foi insuficiente para barrar a cobrança de mensalidades nos cursos de especialização e para impedir o alastramento da prestação de serviços remunerados, antes esporádicos ${ }^{133}$.

A implementação da cobrança de mensalidades para os cursos de especialização da UFG não provocou grande oposição do movimento docente, que assume clara posição em prol da gratuidade da universidade pública. A Associação de Docentes da UFG (Adufg) registrou sua preocupação com essa questão em editorial do Jornal da Adufg (1999: 2). Segundo o editorial, a tática do governo é desmoralizar a universidade, apresentando-a como ineficaz e cheia de servidores com privilégios.

\footnotetext{
O objetivo principal é destruir a nossa auto-estima, transformando-nos em horistas à cata de atividades que complementem nosso salário. Outra estratégia é fazer com que nos apeguemos aos ganhos extras, por meio da criação de cursos pagos de especialização (...). A universidade e a nossa condição de produtores de conhecimento estão sendo atingidas por medidas que têm mudado o nosso perfil institucional e profissional.
}

\footnotetext{
133 É comum, na UFG, a identificação da extensão com a captação de recursos, que é tida,
} por muitos, como área, por excelência, de prestação de serviços remunerados. 
A Adufg entende que é preciso somar forças nessa luta ou, então, prevalecerá a lógica desagregadora da competitividade da política atual.

A ausência de força de reação mais intensa à cobrança de mensalidades nos cursos de especialização da UFG deve-se, provavelmente, ao fato de que muitos professores já realizavam alguma forma de serviço remunerado, em decorrência das suas atividades acadêmicas. Muitas unidades entendiam que os recursos advindos de serviços remunerados possibilitariam a manutenção e a melhoria de sua infra-estrutura, bem como complementaria os baixos salários existentes na instituição. Era uma questão de sobrevivência, ouvia-se. Argumentou-se também que a cobrança de cursos de especialização e a prestação de serviços de um modo geral, se realizados com controle, seriam uma forma de preservar a gratuidade da graduação e da pós-graduação stricto sensu. Segundo os defensores da idéia, tratava-se também de uma questão de justiça social. Afinal, por que não cobrar por um curso de especialização, cuja clientela tivesse poder aquisitivo elevado, e que levaria o diplomado a ampliar o seu ganho em decorrência do curso? Era preciso sair na frente e regulamentar essa área de atuação da instituição, a prestação de serviços, que estava sem direção, cujos beneficios não eram canalizados para investimento na própria universidade. Esse encaminhamento foi dado pela Reitoria, ainda em 1997.

De um modo geral, talvez seja correto afirmar que as práticas de prestação de serviços existentes na UFG e a argumentação bastante convincente em seu favor fizeram cair o tabu da gratuidade absoluta, que havia na instituição. Defendeu-se, todavia, que a cobrança de mensalidade nos cursos de especialização não poderia ser uma regra. A idéia era resguardar casos de alta relevância social e acadêmica em que fosse fundamental manter a gratuidade, embora essa prática estivesse cada vez mais rara na instituição. Com esse espírito, foi idealizada e estabelecida a Resolução no 2/97, do Conselho Universitário (UFG. Consuni, 1997), que 
regulamenta os serviços prestados. Essa medida pode ser considerada fato marcante no processo de metamorfose da instituição ou, pelo menos, o reconhecimento de uma mudança de cultura acadêmica que já vinha ocorrendo, uma vez que legaliza e institui uma nova dinâmica e uma nova mentalidade na prestação de serviços remunerados ${ }^{134}$.

A prestação de serviços remunerados, prevista na Resolução no 2/97, é conceituada como "atividades de transferência à comunidade do conhecimento gerado e/ou instalado na instituição" (§ 1ำ, art.1의), incluindo-se, portanto, no que couber, as atividades remuneradas de consultorias e assessorias, bem como os cursos de especialização, de extensão ou de treinamento (§ 2ำ, art. 2ํ). Há uma preocupação acentuada com as formas de aprovação, acompanhamento e avaliação da prestação de serviços remunerados na instituição. Por isso, com esse controle, a instituição realça o papel dos conselhos e dirigentes da universidade. Define que a carga horária anual para essas atividades não pode ultrapassar 312 horas, cerca de seis horas semanais (art. 3의), que o sobreganho salarial do servidor não pode ultrapassar o valor de seus rendimentos liquidos anuais na UFG (art. 4ㅇ) e que essas atividades não podem prejudicar o oferecimento das outras atividades relacionadas ao ensino, à pesquisa e à extensão (parágrafo único do art. 60). Estabelece exigências acadêmicas para os projetos de prestação de serviços (art. 7으), bem como privilegia o pessoal dos quadros ativo e inativo da instituição. A intermediação de fundações credenciadas, na gestão dos recursos financeiros, é amplamente incentivada (§ 2ㅇ, art. 8ㅇ; parágrafo único do art. 11 ; art. 12).

Além disso, a Resolução no 2/97 dá origem a dois fundos: um institucional, e um local, contabilizados com base nos recursos para custeio

\footnotetext{
$134 \mathrm{Um}$ aspecto fundamental dessa mudança de cultura, no trato das questões acadêmicofinanceiras, é a da atual estratégia de negociação na venda de serviços e produtos. Quando não era muito comum a cobrança de serviços em cursos de especialização, por exemplo, havia preocupação maior com a questão acadêmica do curso. Presentemente, em geral, a estratégia inicial é, primeiro, verificar a viabilidade financeira do projeto ou atividade para, depois, observar os aspectos acadêmicos.
} 
nos projetos, já que os recursos para investimento não contam ${ }^{135}$. Assim, um percentual de $5 \%$ deve ser destinado à constituição de um Fundo Institucional na Universidade e um percentual minimo de $10 \%$, à constituição de um fundo local na unidade acadêmica136. Atribui-se à Reitoria a elaboração de mecanismos de operacionalização e controle interno dessas atividades (art. 50). A Resolução, no entanto, prevê relatório geral e balanço financeiro das prestações de serviços remunerados ao final de cada exercício fiscal (art. 14의), o que ainda se encontra em processo de estruturação.

A Resolução no 2/97 prevê também seu detalhamento nas unidades acadêmicas da UFG. Na Faculdade de Educação (FE), por exemplo, a prestação de serviços remunerados foi regulamentada pela Resolução do Conselho Diretor no 13/98 (UFG. Faculdade de Educação, 1998). Essa unidade estabelece a carga horária semanal de oito horas semanais na média anual para a prestação de serviços, totalizando, no máximo, 416 horas anuais. Como se vê, há um acréscimo de duas horas semanais em relação à Resolução no 2/97, do Conselho Universitário, o que parece ser ilegal por tratar-se de norma inferior. A FE/UFG também demonstra, em sua Resolução, preocupação com a ordem de prioridade na contratação de servidores (docentes e funcionários). Coloca, em primeiro lugar, os docentes da ativa na $\mathrm{FE}$, depois, os inativos da mesma unidade e, por último, os servidores de outras unidades da UFG e outros (sic). Exclui, da participação em atividades de prestação de serviços remunerados, os docentes e demais servidores que estejam em qualificação ou que não tenham seu plano de trabalho aprovado no respectivo departamento. Além disso, institui que a escolha dos coordenadores de projeto seja feita pelo Conselho Diretor da unidade.

135 Essa questão ainda não está muito clara, e existem divergências na UFG quanto aos recursos que deverão ser contabilizados para os fundos.

136 Além disso, há a taxa de administração da fundação responsável que, no caso da Fundação de Apoio à Pesquisa (Funap), representa 10\% das receitas dos projetos. 
No cômputo geral, atualmente, a administração superior da universidade possui grande preocupação em melhor controlar o fluxo de recursos, bem como ampliar o gerenciamento e a avaliação dos serviços e cursos realizados ${ }^{137}$. Sempre que se apresenta um curso de especialização para discussão, é comum a imediata cobrança da planilha de custos (receita e despesas), mesmo que seja oferecido gratuitamente. Há uma preocupação permanente dos gestores da instituição, evidenciada nas reuniões dos conselhos e das câmaras, com o repasse dos percentuais dos fundos institucionais $(5 \%)$ e locais $(10 \%)$, o que ocorre porque ainda não estão consolidados como rotina. No início de 1999, algumas unidades começaram a enviar, pela primeira vez, o relatório geral e balanço financeiro das prestações de serviços remunerados do ano anterior (art. 14). Os relatórios encaminhados dão conta de que a maioria das unidades operam por meio das fundações, o que indica que a consolidação dos fundos depende, em grande parte, dessas instituições de apoio ${ }^{138}$.

Assim, atualmente, fica extremamente dificil definir o montante dos recursos de serviços prestados remunerados na UFG, até que os fundos, institucional e local, estejam plenamente em funcionamento. Sabe-se que esses recursos são hoje bastante relevantes para a complementação dos salários dos docentes e de servidores, bem como contribuem para a manutenção e a melhoria da infra-estrutura física e de equipamentos das unidades acadêmicas. Em que pese o esforço atual para controlar os recursos de serviços remunerados, é preciso lembrar, ainda, que nem todas as atividades que envolvem a entrada de recursos, especialmente para docentes, são registradas. Algumas atividades docentes de prestação de

\footnotetext{
137 Preocupação evidenciada na Ata do Cepec de 16 abril de 1999.

138 Os gestores da universidade também reclamam o fato de que "a Resolução no 2/97 tem sido muito lembrada com relação aos fundos, mas esquecida quanto aos relatórios de avaliação" (UFG. Ata da Câmara de Pesquisa e Pós-Graduação, 11 mar. 1999). Entendem, todavia, que o gerenciamento e a avaliação virão com a consolidação dos fundos e com a obediência dos projetos às resoluções em vigor na UFG. A tradição, em algumas unidades, é um dos fatores que impedem o processo de adequação dos cursos de especialização às normas atuais da UFG.
} 
serviços remunerados ocorrem individualmente e não se enquadram na Resolução no 2/97, não sendo, por isso, inteiramente controladas. Concluise, portanto, que será sempre dificil dizer, com precisão, o valor dos recursos de serviços remunerados na UFG.

Essa situação, na verdade, vincula-se a um processo mais amplo de atualização da cultura das unidades, dos cursos e dos docentes, que estão empreendendo dinâmicas próprias de prestação de serviços remunerados, o que parece ocorrer naturalmente no cotidiano da instituição, já que "tudo parece girar em torno da busca de recursos para a universidade"139.

O exemplo mais marcante da nova cultura pode ser observado na evolução dos cursos de especialização, em que a cobrança de mensalidade já é uma realidade na quase totalidade das unidades da UFG. A Faculdade de Educação constitui-se praticamente na única unidade acadêmica que resiste a essa cobrança ${ }^{140}$. Essa posição, no entanto, é cada vez mais difícil de ser sustentada, sobretudo porque tira o professor da graduação e tem um custo para a UFG ${ }^{141}$. Esta não consegue e não quer mais assumir esses gastos, uma vez que não há mais fomento do MEC para os cursos de especialização. Por isso, esses cursos devem ser autofinanciáveis, segundo entendimento da Andifes $^{142}$. Não cobrar tornou-se um sacrificio para os docentes envolvidos e para a unidade acadêmica em questão, assim como para a UFG ${ }^{143}$.

\footnotetext{
139 Depoimento de membro da Câmara de Extensão, em reunião realizada no dia 18 de março de 1999.

140 A gratuidade nos cursos de especialização na FE/UFG é um dos fatores que atrai grande contigente de candidatos. Para se ter uma idéia, para o ano letivo de 1999 foram inscritos 810 candidatos para três cursos de especialização, que somavam 120 vagas.

141 Declaração da Coordenadora de Pós-Graduação na Reunião da Câmara de Pesquisa e Pós-Graduação, ocorrida em 22 de abril de1999.

142 Segundo informações da Coordenadora de Pós-Graduação da UFG, em reunião da Câmara de Pesquisa e Pós-Graduação, ocorrida em 8 de abril de 1999, praticamente não há mais cursos gratuitos, em nível de especialização, nas IES públicas, especialmente nas Ifes. É interessante que, segundo entendimento da legislação atual, não se podem cobrar mensalidades mas taxas acadêmicas, o que leva as universidades a receberem as mensalidades por intermédio de fundações credenciadas pelo MEC.

143 De um modo geral, pode-se afirmar que a cultura da cobrança dos cursos de especialização, serviços e produtos já está incorporada no cotidiano da UFG. Os órgãos superiores demonstram preocupação em fazer valer a Resolução no 2/97 (Prestação de Serviços Remunerados) que assegura percentual para UFG e para a unidade de origem.
} 
Uma das decisões da UFG, no processo de implementação da Resolução no 2/97 e da Gratificação de Estímulo à Docência (GED), é que as atividades docentes remuneradas não poderão ser registradas no Relatório Anual de Atividade Docente (Radoc) e nem pontuadas para efeito da GED. Compreende-se que os professores assumem uma carga horária adicional de atividades remuneradas como um sobre-trabalho que garante complementação salarial. Nesse sentido, há uma preocupação da administração superior da UFG em identificar as atividades remuneradas para que elas não sejam indevidamente computadas, o que se deve ao crescente volume de atividades de prestação de serviços e à dificuldade de identificar as remuneradas, já que não está fácil a implementação da Resolução no 2/97, no que tange aos fundos locais e institucionais, relatórios de avaliação das atividades e prestação de contas. Essa, no entanto, não é uma questão consensual. Verificam-se discordâncias quanto à decisão de excluir da pontuação da GED atividades docentes curriculares, mesmo gerando recursos para a unidade acadêmica. Para alguns professores, "se a atividade é curricular, mesmo fazendo entrar recursos na unidade, ela deve ser computada para efeito de GED"144. O mesmo deveria ocorrer com as atividades de pesquisa, ou seja, com o processo, e não só com os produtos de pesquisa.

\section{O movimento na área de avaliação}

A movimentação institucional na área de avaliação, na UFG, pode ser vista, sobretudo, com base em dois processos basicamente paralelos: a disputa entre Programa de Avaliação Institucional das Universidades Brasileiras (Paiub) e Exame Nacional de Cursos (ENC) e a implantação e consolidação da Gratificação de Estímulo à Docência (GED). Os dois

\footnotetext{
144 Declaração de conselheiro em reunião da Câmara de Pesquisa e Pós-Graduação, em 22
} de abril de 1999. 
movimentos tiveram impacto bastante diferenciados na produção do trabalho e da vida acadêmica da instituição. O primeiro processo iniciou-se em 1995, com a introdução da avaliação institucional, de acordo com modelo do Paiub, que se tornou um contraponto acadêmico à forma, ao conteúdo e às finalidades da avaliação empreendida pelo ENC, instituído pela Lei no 9.131/95. O segundo teve início com GED, introduzida pela Lei no 9.678/98, que está promovendo mudanças significativas na dinâmica do campo institucional e na produção do trabalho e da vida acadêmica (Catani e Oliveira, 1999a; Dagnino, 1999). Atualmente, os dois processos seguem na universidade, embora o segundo tenha sobrepujado o primeiro.

Embora os dois processos façam parte de um todo, que explicita o movimento de avaliação na UFG, é preciso considerá-los separadamente, por três razões. A primeira diz respeito ao fato de que a GED foi tratada separadamente do Paiub e do ENC, conhecido como Provão. Não houve grande movimentação ou discussões mais totalizadoras, em nível nacional e na UFG, sobre a possivel integração no sistema de avaliação. Também, não se verificaram tentativas de articular os dois processos de avaliação, embora a Comissão de Avaliação Institucional da UFG tenha participado da Comissão da GED. A segunda refere-se à tamanha importância que a GED adquiriu na universidade, seu profundo impacto no trabalho docente e às diferentes lógicas constitutivas desses processos de avaliação. A terceira diz respeito à necessidade didática de apresentar esses processos da forma como se deram, ou seja, separadamente.

\subsection{Programa de Avaliação Institucional das Universidades Brasileiras (Paiub) e Exame Nacional de Cursos (ENC): disputa e acomodação}

O primeiro processo de movimentação na área de avaliação provocou forte reação da UFG contra o Exame Nacional de Cursos (Provão), assim como da maioria das Ifes. Dentre as razões mais evidenciadas encontram-se: 
discordância quanto ao método de avaliação, especialmente por ser momentânea e não conseguir captar todo o trabalho acadêmico e mesmo o saber do aluno; desconfiança dos objetivos finais e do uso dos resultados do Provão, especialmente quanto ao estabelecimento de ranking e de mecanismos de financiamento; defesa do Paiub, programa do próprio MEC, que promove avaliação ampla, valoriza o processo de desenvolvimento institucional e respeita a autonomia e a identidade institucional (Dias Sobrinho, 1998).

$\mathrm{Na}$ universidade, especialmente na administração superior, prevalece o entendimento de que a avaliação institucional seria fundamental como suporte à tomada de decisão e definição de politicas, assumindo internamente, também, grande importância com o advento da autonomia universitária. Nesse sentido, os processos de avaliação e de modelação da UFG, que se instalavam de modo progressivo, além de modernizar o gerenciamento da instituição, tem como uma das suas finalidades preparar a universidade para o exercício da autonomia plena.

A administração superior da instituição, por ocasião da implantação do Provão, fez circular artigos, notas e declarações que expressavam sua posição desfavorável à adoção do exame ${ }^{145}$, sendo essa também uma posição da Andifes. Os conceitos $E$ obtidos pelos cursos de Direito e de Engenharia Civil da UFG, em 1996, expressam a tomada de posição contrária ao ENC, já que houve amplo boicote. Nos anos seguintes, essa resistência foi diminuindo, dependendo do curso. Em 1999, já se pode afirmar que o Provão foi incorporado no cotidiano de trabalho da instituição. Não há mais discussões acaloradas ou frias contra o Exame. Pelo contrário, os procedimentos para sua realização já se tornaram uma rotina, o que pode ser evidenciado por meio da preocupação da Pró-Reitoria de Graduação em alertar os coordenadores dos cursos de graduação para os prazos de inscrição dos 
alunos, objetivando não prejudicá-los, uma vez que os coordenadores de curso são os responsáveis diretos pela inscrição dos alunos aptos ao ENC. É claro que o prejuízo é, também, institucional, embora não seja tão explicitado atualmente.

O posicionamento atual em relação ao ENC é compreensivel, uma vez que a divulgação de seus resultados é acompanhada de uma série de ameaças (do governo) quanto ao fechamento dos cursos, transferências de alunos e não emissão dos diplomas. Além disso, o exame reforça um espírito de competição e de ranking das IES. Embora não concordem com o exame, as instituições temem os seus efeitos, sobretudo em termos de perda de status acadêmico na sociedade e de prejuízo no tratamento dispensado pelo MEC, instituições financiadoras e campo acadêmico, em geral.

\subsection{Gratificação de Estimulo à Docência (GED): alterações e implicações}

No segundo processo de movimentação da área de avaliação, observouse uma reação ainda mais forte da UFG à implantação da GED, assim como na maioria das Ifes. Do mesmo modo que o Provão, definiu-se a GED mediante uma intervenção consciente e deliberada do Estado. Nesse caso, no entanto, ela conseguiu mobilizar mais intensamente o corpo docente porque atingiu seu comportamento profissional, uma vez que os vencimentos de estimulo resultariam de um tipo ideal de desempenho e de produção docente (Catani e Oliveira, 1999a).

A reação inicial tinha sua razão de ser, já que a investigação e a análise crítico-interpretativa dos efeitos da GED, na UFG, evidenciam intensa modificação na dinâmica do campo e na produção do trabalho acadêmico, especialmente na forma de avaliação e de gestão da instituição. As mudanças processam-se cotidianamente e são reveladoras do processo de metamorfose institucional. Na prática, confirmam o surgimento de uma nova mentalidade produtiva, baseada na alteração do comportamento docente, na remodelação 
dos mecanismos de informação, de controle e de avaliação das atividades docentes e nas novas atitudes presentes no processo de tomada de decisão.

De imediato, a GED intensificou na UFG a necessidade de registrar, controlar e uniformizar o desempenho docente em suas diferentes áreas, o que significa uma definição ou uma readequação de critérios, objetivando enquadrar o trabalho docente. Essa atitude, do ponto de vista da gestão da instituição, observada em seus diferentes órgãos colegiados, teve e tem reflexos imediatos no comportamento docente, em que se observa grande empenho na adequação do trabalho aos elementos mais valorizados na GED.

O ensino, na forma de aula, passa a ser o objeto privilegiado do processo de adequação do trabalho docente. Em geral, "o docente prefere dar aulas para atingir maior pontuação"146. Na GED/1998, a avaliação quantitativa e qualitativa foram plenamente atendidas em virtude de maior dedicação ao ensino, já que "os docentes com carga horária semanal média superior a 16", puderam "utilizar o valor excedente a este número na avaliação qualitativa", atingindo a pontuação máxima da GED (§ 3ọ, do art. 5ọ, da Resolução Cepec no 1/98) ${ }^{147}$, o que parece desestimular as atividades de pesquisa e, ao mesmo tempo, valorizar as de ensino na graduação ${ }^{148}$.

As novas necessidades de controle e avaliação do desempenho docente, criadas pela GED, racionalizam e fortalecem os processos, os sistemas e os mecanismos de informação e de avaliação da UFG, bem como as próprias comissões de avaliação existentes na instituição. Em 1998, foi criada a Comissão Institucional de Avaliação de Desempenho Docente (CIADD),

\footnotetext{
146 UFG. Ata da Sessão Conjunta do Consuni/Cepec, realizada em 6 de novembro de 1998. 147 A avaliação da GED/2000 que considerou o uso da carga horária excedente, recebeu parecer contrário da Comissão Nacional, que orientou a UFG a observar "os limites de 120 pontos para ensino (e, dentre eles, no máximo 40 para atividades de orientação) e 60 para a avaliação das demais atividades". Além disso, era considerada somente a produção de 1999, em todos os itens (Brasil. MEC/SESu/Comissão Nacional de Acompanhamento e Orientação da GED, 1999).

$148 \mathrm{Na}$ pontuação dos itens, objetivando a GED 2000, a UFG procurou corrigir essa distorção, mediante maior valorização das atividades de pesquisa.
} 
responsável pela implantação, ou melhor, pela pontuação da GED ${ }^{149}$. Essa Comissão, conforme prevê a Resolução Consuni nำ1/98, contou com a colaboração da Comissão de Avaliação Institucional (Cavi), responsável pelo Paiub da UFG, e da Comissão Permanente de Pessoal Docente (CPPD), responsável pelos processos de avaliação vertical e horizontal dos docentes, bem como com o auxílio do Centro de Processamento de Dados (CPD) e do Departamento de Pessoal (DP) da UFG ${ }^{150}$.

Para efeito de recebimento da GED, realizou-se a avaliação com base nas informações constantes do Relatório Anual de Atividade Docente (Radoc), que registra todas as atividades executadas de cada professor, conforme prevê o art. 2o da Resolução no 1/98. Esse Relatório já estava razoavelmente consolidado na grande maioria das unidades acadêmicas da UFG e, por isso, não houve grandes traumas em utilizá-lo como parâmetro básico para os cálculos da GED. O Radoc já era, na UFG, a referência para a avaliação da produtividade docente, o que ocorreu, provavelmente, porque era tomado como documento informativo básico nos processos de estágio probatório e de avaliação vertical e horizontal. Todavia, com a GED, esse Relatório passou a ser utilizado de uma forma peculiar, não imaginada anteriormente.

De um modo geral, os resultados da implantação da GED, na UFG, conseguem traduzir a existência de uma nova postura com o desempenho docente na instituição, evidenciada sobretudo no processo de distribuição da GED/1998, como mostra a tabela 15. Os percentuais de obtenção da GED demonstram que a UFG foi mais rigorosa do que o conjunto das Ifes, nas quais $64,52 \%$ dos docentes obtiveram a pontuação máxima, enquanto na UFG o percentual foi de 55,25\%. Logo que esses e outros dados da GED/ 1998 ficaram conhecidos, tornou-se comum ouvir, nos colegiados e nas

\footnotetext{
149 Essa Comissão foi criada somente para proceder a pontuação da GED/1998, em seguida, extinta, uma vez que contava com docentes externos à UFG, em conformidade com a Lei no 9.678/98. Cada processo de avaliação exige a nomeação de nova comissão.

150 A CIADD compunha-se de três representantes do Cepec, do presidente da CPPD, do presidente da Cavi e de quatro Professores Doutores externos à UFG (art. 1ํ da Resolução no $1 / 98)$
} 
assembléias do movimento docente, que a UFG foi mais realista que o rei na concessão dessa gratificação, já que a maioria das Ifes não adotou critérios tão rígidos e excludentes. Pelo contrário, algumas atribuíram quase totalidade da GED aos professores.

Tabela 15 - Distribuição da GED nas Ifes e na $\mathrm{UFG}^{151}$

\begin{tabular}{|c|c|c|}
\hline Item & $\begin{array}{c}\text { Ifes } \\
\mathbf{N}(\%) \\
\end{array}$ & $\begin{array}{c}\text { UFG } \\
\mathbf{N}(\%) \\
\end{array}$ \\
\hline Docentes Avaliados & $40.646(94,77)^{152}$ & $1.115(96,12)$ \\
\hline Obtiveram alguma gratificação (de 1 a 140 pontos) & $(99,18)$ & $1.115(100)$ \\
\hline Obtiveram pontuação máxima (100\% da GED) & $(64,52)$ & $616(55,25)$ \\
\hline Obtiveram de 121 a 139 pontos & $(11,74)$ & $162(14,53)$ \\
\hline Obtiveram 120 pontos & $(3,54)$ & $15(1,35)$ \\
\hline Obtiveram de 85 a 119 pontos & $(8,59)$ & $141(12,65)$ \\
\hline Obtiveram 84 pontos (60\% da GED) & $(5,21)$ & $81(7,26)$ \\
\hline Obtiveram 83 pontos ou menos & $(5,59)$ & $100(8,96)$ \\
\hline Obtiveram zero pontos & $(0,82)$ & - \\
\hline Média de pontos obtidos & $\mathbf{1 1 9 , 8 0}$ & $\mathbf{1 1 7 , 5 3}$ \\
\hline
\end{tabular}

Fonte: Belloni (1999) e diversos documentos da UFG.

A instituição da GED provocou também mudança bastante curiosa na avaliação docente, em geral. Os processos de estágio probatório, de demissão de professores ou mesmo de progressão estão, cada vez mais, respaldados ou legitimados, com os dados obtidos nessa forma de gratificação, o que significa, no mínimo, que a GED serve a propósitos diferentes daqueles para os quais foi criada, tamanha a importância que adquiriu na instituição. Segundo membro do Cepec, "não é muito bom que haja mistura entre a

151 Os dados gerais das Ifes foram colhidos no texto de Belloni (1999) e os relativos à UFG, em diversos documentos da instituição..

152 De acordo com Belloni (1999), o número de cargos providos nas Ifes, em novembro de 1998, era de 42.889 professores. Existem ainda 5.389 docentes extraquadro (visitantes e substitutos) que não participaram do processo GED/1998. 
avaliação da GED e a do estágio probatório, em razão de serem totalmente distintas e realizadas de formas diferentes" (UFG. Ata do Cepec, 9 mar. 1999: 2). Essa opinião, no entanto, não é corroborada pela maioria dos membros e da Presidente do Conselho, a qual

afirma concordar que as duas avaliações são distintas; contudo, esclarece que é importante que se tenha em mente que o instrumento que avalia a GED e o estágio probatório é o mesmo, ou seja, o Radoc, que proporciona uma visão do todo (UFG. Ata do CEPEC, 9 mar. 1999: 2).

Além disso, a GED parece tomar concretamente o lugar de processos de avaliação interna que foram construidos a duras penas na UFG (e nas Ifes), podendo até esfriar ainda mais o Paiub da UFG, do ponto de vista de sua importância no processo de planejamento e tomada de decisão. A avaliação mais ampla das atividades docentes e do desenvolvimento institucional, como prevê o Paiub, pode dar lugar a formas de avaliação nãocondizentes com os compromissos e com a identidade da UFG. O crescimento da importância dada a essa nova forma de remuneração leva o movimento docente a insistir em sua posição, utilizando a mesma argumentação de Belloni, segundo a qual,

a GED é um procedimento para atribuição de gratificação pecuniária por atividade realizada. Não se constitui, portanto, em um processo de avaliação de desempenho docente pois os objetivos e critérios (...) não correspondem àqueles pertinentes à avaliação educacional e institucional (Belloni, 1999:1).

De um modo geral, a UFG mudou de atitude no tratamento aos processos de avaliação dos docentes, uma vez que a tolerância e a acomodação em relação a professores, que não somam para a unidade acadêmica ou para a universidade, deram lugar à busca de docentes com alto desempenho e perfil adequado aos processos competitivos que se instalam. Um exemplo dessa nova atitude é dispensada aos processos de docentes, que pleiteiam progressão vertical, apresentando justificativa 
acadêmica, sem terem obtido titulação correspondente (mestrado ou doutorado). Os conselhos e câmaras da UFG passaram, a partir do início de 1999, a indeferir a maior parte desses processos, embora, anteriormente, muitos processos fossem aceitos com base na Resolução no 386/95153.

O Cepec entende que embora os salários sejam baixos, não se pode fazer vista grossa a esses casos (UFG. Ata do Cepec, 16 mar. 1999). Reconhece que não há mais espaço para esse tipo de demanda e, por isso, a legislação da instituição precisa ser revista. A pressão pela maior titulação nas Ifes, decorrente da LDB, e pelo maior desempenho docente, ampliou as exigências para a progressão vertical e horizontal. A nova atitude do Cepec, na ocorrência de solicitação de progressão sem os devidos títulos e, em alguns casos, com certa aquiescência das unidades acadêmicas, tem sido a de interpelar a unidade e o docente quanto ao motivo da não-licença e da não-realização de curso de pós-graduação stricto sensu. Às vezes, o questionamento é feito valendo-se do fato de "se considerar estranho a unidade em questão estar aprovando e oferecendo vários cursos de especialização", em que ocorre a cobrança de mensalidades bastante altas, e não haver disponibilidade para liberação de professores. Questiona-se então a prioridade da unidade e do docente ${ }^{154}$.

O maior rigor na avaliação docente também já se manifesta nos Conselhos Diretores das Unidades (CDs), especialmente no caso dos processos de demissão de professores que não são aprovados durante o Estágio Probatório, o que recebe pleno endosso do Cepec e do Consuni ${ }^{155}$. Vem crescendo, assim, o número de professores reprovados no Estágio

\footnotetext{
153 Criou-se uma Comissão para alterar a legislação e impedir que, sequer, esses processos fossem formados, uma vez que os conselhos deliberativos da UFG sentem-se pressionados pelas exigências atuais de titulação e não acreditam que exista justificativa acadêmica que substitua a obtenção da titulação.

154 Comentários e questionamentos feitos por conselheiro na Reunião do Cepec, realizada em 16 de março de 1999.

155 Esses processos geram muita tensão e conflito no âmbito da instituição. Em geral, é preciso constituir comissões interdepartamentais para análise dos processos, quando apresentam alto grau de complexidade.
} 
Probatório. Os CDs assumem a clara posição de demissão dos professores que não possuam perfil acadêmico ou comportamento adequado aos anseios das unidades acadêmicas, o que ocorre mesmo em um momento em que as unidades não têm certeza de poder contar com vaga para realização de novo concurso. A entrada de docentes tornou-se uma questão de investimento acadêmico extremamente séria.

A nova disposição acadêmica, diante dos processos de avaliação docente, certamente explicita uma postura mais exigente da UFG, no tocante à avaliação do desempenho, à carreira e à capacitação docente. O professor passa a ser cobrado mais diretamente por sua titulação e seu desempenho, em que pese a responsabilidade da instituição na implementação de plano de capacitação. A progressão na carreira, de igual modo, passa a ser mais controlada e zelada, eliminando resíduos de proteção indiscriminada dos pares.

Um outro aspecto dos efeitos da GED, na dinâmica do campo e na sua produção, que merece destaque, encontra-se no fato de que ela trouxe à tona muitos comportamentos e problemas antes obscurecidos, tornando mais transparentes a produção acadêmica, o processo de tomada de decisão, as práticas docentes e as possibilidades de articulação do trabalho na universidade.

A respeito da alocação de recursos financeiros e de vagas de docentes e servidores técnico-administrativos, por exemplo, que considera, dentre outros elementos, a carga horária média de aula nas unidades acadêmicas, a instituição nunca questiona as informações constantes dos Radocs. Os recursos, apresentados à Comissão de Análise dos Recursos da GED revelam a necessidade de definição de critérios do que pode ser considerado aula na instituição, já que se tornou muito dificil enquadrar/pontuar certas atividades acadêmicas nessa categoria.

A maioria dos recursos apresentados à Comissão de Análise dos Recursos da GED/1998 baseou-se nas alterações feitas nos Radocs. De um 
modo geral, os docentes procuraram documentar, registrar atividades esquecidas ou reclassificar as atividades realizadas em itens mais pontuados pela GED, como é o caso da aula. Essa situação evidenciou dois problemas. O primeiro é que, ao que parece, anteriormente, alguns professores não se preocupavam em registrar todas as atividades acadêmicas no Radoc, bem como não havia padronização das atividades informadas ou mesmo rigor na averiguação das informações prestadas. O segundo diz respeito aos diferentes entendimentos do que pode ser considerado aula, atividade mais pontuada na GED e, portanto, objeto de disputa no campo.

A Comissão de Análise de Recursos à GED/1998 levantou esse problema com base nas alterações que os docentes fizeram, especialmente nas disciplinas de estágio ou consideradas práticas, nas quais, em alguns casos, não ficava claro a caracterização da aula e nem o papel do professor naquela atividade ou disciplina ${ }^{156}$. Salientou, também, o fato de que algumas dessas disciplinas são assumidas por vários professores e de diferentes formas, em que cada um registra a totalidade da carga horária. Caso esses novos registros fossem aceitos nos Radocs, haveria grande viés nos cálculos de pontuação da GED, além de inviabilizar os modelos de alocação de vagas e de recursos financeiros da UFG. Por exemplo, se um professor que compartilhava uma disciplina prática com outros docentes, atendesse pontualmente ou esporadicamente a alguns alunos e registrasse a totalidade da carga horária dessa disciplina, em seu Radoc, alcançaria mais do que os 140 pontos da GED somente nessa atividade. Nos recursos apresentados, ocorreram casos de professores que registraram, no primeiro Radoc, meia hora/aula semanal e, no segundo Radoc, 21 horas/aula semanais.

Problemas dessa natureza foram identificados, sobretudo, nos recursos dos docentes oriundos das Faculdades de Odontologia e Medicina. Até abril de 1999, esses recursos não haviam sido julgados em razão da "falta de

156 A Comissão apresentou esse problema na reunião da Câmara de Graduação, em 26 de abril de 1999. 
uniformização nos dados apontados nos Radocs de 1998, referentes às atividades de ensino e extensão" e a ausência de documentação comprobatória, especialmente da carga horária de aula, segundo explicita Relatório da Comissão de Análise de Recursos da GED/1998. Na Faculdade de Medicina, por exemplo, as atividades docentes da Residência Médica (ambulatório, procedimentos clínicos etc.) que, em geral, eram registradas pelos docentes como orientação e extensão, foram reclassificadas como aula. O mesmo ocorreu na Faculdade de Odontologia, especialmente na disciplina Clínica Integrada157. Essa situação levou a Comissão a solicitar ao Cepec/Câmara de Graduação a normatização dos dados dessas faculdades, ou seja, a definição de critérios que permitissem enquadrar as atividades docentes. A preocupação central da Comissão era definir ensino-aula, ensino-orientação, ensino-acompanhamento etc.

Além dessa postura em prol da definição de critérios, outros entendimentos surgiram nos órgãos colegiados, e os mais evidenciados foram: a defesa de que a UFG devia conceder a totalidade da GED aos seus professores, em razão dos baixos salários, já que outras Ifes o fizeram ${ }^{158}$; o entendimento de que as especificidades de formação, do ponto de vista disciplinar e das atividades desenvolvidas, devem ser respeitadas, por isso, os critérios da GED não podem ser os mesmos para toda universidade; a idéia de que o que faz parte da grade curricular do curso de formação, ou seja, que é necessário para integralização do currículo, deve contar como aula; a impossibilidade de separar aula-teórica de aula-prática, bem como atribuir menor valor a aula-prática, dividindo-a em várias atividades ${ }^{159}$.

\footnotetext{
157 Em debate sobre o assunto, em sessão da Câmara de Graduação, ocorrida em 10 de maio de 1999, foi dito que "na Odontologia, os professores não estão querendo mais assumir a Clínica Integrada, já que ela não pontua como aula. Por isso, a GED está prejudicando a especificidade do curso".

158 Informou-se em sessão da Câmara de Graduação, ocorrida em 10 de maio de 1999, que o MEC questionou as Ifes que atribuíram 140 pontos à maioria ou à totalidade dos docentes e que muitas professores iriam devolver dinheiro.

159 No caso específico da Medicina, por causa da urgência no fechamento dos processos e da dificuldade na definição de critérios aceitáveis, decidiu-se que os professores que atuaram
} 
As discussões atuais em torno da pontuação da GED, na UFG, assim como na maioria das Ifes, deixam claro que a posição inicial do movimento docente em lutar pela generalização da totalidade da GED, para os docentes, encontra-se bastante enfraquecida. De certo modo, a GED promoveu algumas mudanças almejadas por muitos administradores e docentes da instituição, e é vista como forma de induzir políticas de desenvolvimento institucional.

No decorrer de 1999, observou-se uma disputa interna, mesmo na administração superior, objetivando pontuar melhor essa ou aquela atividade, ao mesmo tempo que houve maior movimentação e crescimento de uma consciência, com o objetivo de ampliar a pontuação na área de produção científica, tecnológica, artística e cultural, bem como a defesa de que a GED reconheça os produtos de pesquisa, mas também o processo de pesquisa (atividades de desenvolvimento da pesquisa). Embora não seja hegemônica, essa defesa vem crescendo e poderá concretizar-se, paulatinamente, com os processos de avaliação para efeito de GED, dependendo da correlação de forças no campo'160.

Cabe ainda salientar que o processo de avaliação, em relação à GED/2000 foi mais eficiente, segundo o Pró-Reitor de Desenvolvimento Institucional e Recursos Humanos ${ }^{161}$. Em 1998, foram encaminhados 230 recursos, enquanto na GED/2000 apenas 135, dos quais, cerca de 95\% foram deferidos, e 80 obtiveram os 140 pontos. Esse avanço deve-se aos ajustes feitos na pontuação das atividades acadêmicas, ao melhor registro

na Residência Médica poderiam registrar, somente para a GED/1998, oito horas/aula semanais, no máximo. Na Odontologia, os professores poderiam registrar três horas/aula semanais para Clínica Médica I e cinco horas/aula semanais para Clínica Médica II, no máximo.

160 A comparação da tabela de pontuação da GED/1998 com a GED/2000 (UFG. Resolução UFG/Consuni/Cepec no 1/99) já evidencia a inserção de novos itens, novas ênfases ou simplesmente, o aumento da pontuação na área de produção científica, em que pesem as atividades administrativas terem também recebido maior reforço. Segundo consta, o reconhecimento do valor do processo de desenvolvimento da pesquisa e extensão e não apenas os produtos, objetivando a GED/2000, ocorreu de modo generalizado nas Ifes.

${ }_{161}$ Declaração feita em reunião do Cepec, em 28 de setembro de 1999. 
das atividades, à maior aceitação da GED e ao trabalho da Comissão Nacional, que arbitra e normatiza a implementação da GED. O principal problema continua relacionado às alterações no Radoc, sem a devida comprovação, especialmente na carga horária de aula162. De um modo geral, os dados da GED/2000, na UFG, demonstram que essa gratificação é incorporada rapidamente, o que contribui decisivamente para o processo de modelação do trabalho acadêmico e da gestão da universidade.

\section{O movimento na área de currículo}

Dentre as áreas consideradas, a de currículo encontra maior resistência no tocante à introdução de mudança, já que não há, ainda, uma consciência acadêmica ou uma mobilização docente mais intensa, objetivando a reestruturação dos perfis, das carreiras e da formação profissional oferecida. Boa parte das unidades acadêmicas da UFG entendem que não há necessidade de mudança nos currículos dos cursos de graduação. Assim, de um modo geral, essa parece ser a área que apresenta menor disposição acadêmica docente para modificar a cultura constituída na universidade ${ }^{163}$.

Atualmente, instalou-se o ideário da flexibilização curricular (Catani, Oliveira, Dourado, 2000), desencadeando uma movimentação bastante significativa, o que se deve, dentre outros fatores:

a) a Lei no 9.131/95, ao instituir o Conselho Nacional de Educação (CNE), define como uma das competências desse órgão deliberar

\footnotetext{
162 Dentre os pontos negativos da GED e identificados em uma avaliação realizada pelo movimento docente, apontou-se: “a preocupação dos docentes com a acumulação de pontos", o que os leva a buscar realizar atividades melhor pontuadas e a criar um clima de competição, em que "quem não tem pontuação é visto como um coitado e quem atinge pontuação excessiva também não é bem visto" (Andes Informa, 2000: 4-5).

163 Essa percepção geral, no entanto, não permite afirmar que os currículos dos cursos de graduação da UFG não sejam oxigenados pelas mudanças no mundo do trabalho e pela produção da ciência e tecnologia em cada área, curso ou disciplina.
} 
sobre as Diretrizes Curriculares propostas pelo MEC, para os cursos de graduação (letra $c$ do $\S 2 \stackrel{0}{ }$, do art. $9^{\circ}$ );

b) a nova LDB, no inciso II do artigo 53, cria a necessidade de Diretrizes Curriculares para os cursos de graduação e permite a eliminação dos chamados currículos mínimos, tornando os currículos de graduação mais flexiveis;

c) a intensificação das discussões internacionais e nacionais sobre diplomas e perfis profissionais, ante as mudanças na sociedade contemporânea e, particularmente, no mercado de trabalho;

d) o processo desencadeado pela Secretaria de Educação Superior (SESu) do MEC, em 1997, objetivando a implementação das Diretrizes Curriculares para os cursos de graduação;

e) a definição de Padrões de Qualidade para os Cursos de Graduação pela SESu;

f) o estabelecimento de critérios sobre a constituição de comissões e procedimentos de avaliação e verificação de cursos superiores;

g) o posicionamento assumido pelo Fórum de Pró-Reitores de Graduação, especialmente no Plano Nacional de Graduação, em prol de Diretrizes Curriculares gerais e fortalecimento dos projetos pedagógicos institucionais e dos cursos de graduação ${ }^{164}$.

A reforma curricular dos cursos de graduação iniciou-se, concretamente, pela SESu/MEC, por meio do Edital no 4, de 4 de dezembro de 1997, a qual solicitou às IES o envio de propostas para a elaboração das Diretrizes Curriculares dos cursos de graduação ${ }^{165}$. Em seguida, essas propostas serviram de base para o trabalho das Comissões de Especialistas de Ensino de cada área. Conforme Edital, a idéia básica do ministério

\footnotetext{
164 Além desses aspectos, no caso da UFG, é necessário ressaltar os problemas e as dificuldades apontadas pela Avaliação Institucional da UFG - 1996 (UFG/PRODIRH, 1996). 165 A SESu/MEC informa que recebeu quase 1.200 propostas das IES, que foram discutidas e sistematizadas por 38 Comissões de Especialistas, contratadas pela SESu. Em seguida, elaborou-se relatório final, que foi encaminhado ao CNE para discussão pública e deliberação.
} 
consistia em adaptar os currículos às mudanças dos perfis profissionais, para o que foram adotados os principios orientadores para as mudanças curriculares dos cursos de graduação: flexibilidade na organização curricular; dinamicidade do currículo; adaptação às demandas do mercado de trabalho; integração entre graduação e pós-graduação; ênfase na formação geral; definição e desenvolvimento de competências e habilidades gerais. Nesse sentido, a reforma possui o objetivo geral, justamente, de "tornar a estrutura dos cursos de graduação mais flexivel"166.

Ao mesmo tempo, o CNE aprovou, em 3 de dezembro de 1997, o Parecer no 776/97 que trata da orientação para as diretrizes curriculares dos cursos de graduação, em que o Conselho assume posição em favor da eliminação da figura dos currículos minimos, que produz excessiva rigidez e fixação detalhada de mínimos curriculares, especialmente no que tange ao excesso de disciplinas obrigatórias e ampliação desnecessária do tempo de duração dos cursos. No lugar dos mínimos, o CNE propõe uma maior flexibilidade na organização de cursos e carreiras profissionais que inclui, dentre outros, os seguintes princípios: ampla liberdade na composição da carga horária e unidades de estudos a serem ministradas, redução da duração dos cursos, sólida formação geral, práticas de estudo independentes, reconhecimento de habilidades e competências adquiridas, articulação teoria-prática e avaliações periódicas com instrumentos variados.

Essas proposições encontram eco e parceria, particularmente, no Fórum de Pró-Reitores de Graduação das Universidades Brasileiras (ForGRAD), segundo o qual as Diretrizes Curriculares devem assegurar que as IES proponham o Currículo em seu sentido mais amplo e que o currículo deve apresentar:

flexibilidade de sua estrutura, permitindo ao aluno diversificação de sua formação (...); variedade na oferta de tipos de atividades para a

\footnotetext{
166 Ver matéria: MEC quer tornar cursos de graduação mais flexiveis. Folha de S. Paulo. São
} Paulo, 30 mar. 1998, p. 2. 
integralização curricular (...); articulação entre atividades desenvolvidas pelo aluno no âmbito da Universidade com aquelas de seu campo de atuação profissional (...); ênfase em atividades centradas na criatividade e na capacidade de (re)construir, (re)estruturar, (re)ordenar e buscar novas interpretações às situações propostas (ForGRAD, 1999: 2).

Por sua vez, a Pró-Reitoria de Graduação da UFG (Prograd) também entende que é preciso flexibilizar os currículos dos cursos de graduação167 com o objetivo de viabilizar a vida estudantil, especialmente dos alunos que trabalham, pois elevado número de alunos deixam a instituição sem concluir o curso ${ }^{168}$. Como na maior parte das IES, há muita tensão e conflito quanto à tomada de posição na área de currículo ${ }^{169}$, embora exista certa concordância de que a formação geral e os currículos multidisciplinares são indispensáveis à formação de um cidadão-profissional capaz de inserir-se criticamente no mundo do trabalho e de lidar com as novas exigências e demandas da sociedade contemporânea ${ }^{170}$.

No entanto, os esforços da administração superior da UFG em estabelecer um novo núcleo de formação e induzir reformas nos currículos plenos dos cursos de graduação esbarrou em uma certa indiferença docente quanto à necessidade de mudança, bem como na discordância sobre os principios e pressupostos presentes na Proposta do Regulamento Geral dos

167 No período da movimentação curricular da UFG (1998-1999), pode-se detalhar a estratégia de mudança da seguinte forma: a) teve início, em 1998, o processo de sensibilização da necessidade de reforma nos currículos plenos dos cursos de graduação, bem como iniciaram-se estudos para a alteração do regime acadêmico e dos currículos dos cursos, mediante trabalho de Comissão designada pela Prograd; b) em 1999, após entrega da proposta final de Regulamento Geral dos Cursos de Graduação, no mês abril, sugeriu-se a discussão nas unidades acadêmicas; c) recebimento das críticas e sugestões das unidades acadêmicas; d) discussão e aprovação do Regulamento na Câmara de Graduação; e) discussão e aprovação no Cepec.

168 Em 1998, mais de 850 alunos deixaram a UFG e, em 1997, foram cerca de 750 . As formas de evasão são diversas: trancamento de matrícula, transferência, abandono, jubilamento, etc ( $\mathrm{sic}$ ). "Isso se deve a falta de flexibilidade do sistema seriado, o que elitiza a graduação" (declaração da Pró-Reitora de Graduação, em reunião da Câmara de Graduação no dia 14 de junho de 1999).

169 Já se observa uma ampla movimentação nas IES, objetivando introduzir mudanças curriculares, especialmente nos cursos de graduação.

170 A Prograd definiu como princípios para uma politica de graduação: "flexibilidade na formação; liberdade para a intervenção do discente na definição de sua formação; adequação 
Cursos de Graduação (RGCG), apresentada por uma Comissão da Câmara de Graduação, designada pela Pro-Reitora de Graduação, em abril de 1999171.

A pouca disposição docente em alterar a cultura existente na área de currículo vincula-se, em grande parte, à experiência histórica da UFG na organização de suas atividades acadêmicas, bem como ao respeito à diversidade que the é constitutiva ${ }^{172}$. A historicidade desse movimento demonstra as razões dessa disposição de boa parte do corpo docente, especialmente com o objetivo de se apegar a principios e valores acadêmicos constituídos com base na reforma curricular e no regime acadêmico, ocorridos na primeira metade da década de 80.

Nas últimas duas décadas, três períodos marcaram o movimento de currículo na UFG. O primeiro de 1983/1984, quando foi aprovada a Resolução no 184/83, que fixa princípios e critérios para elaboração dos currículos plenos, e a Resolução no 194/84, que implantou o regime seriado anual e a reformulação geral dos cursos de graduação da UFG. O segundo período data de 1989, quando foi aprovada a Resolução no 294/89, que estabelece principios e critérios para a elaboração e reformulação dos currículos plenos e dá outras providências. Essa última atualizou os princípios e critérios para elaboração dos currículos plenos, revogando a Resolução no 184/83, mas sem alterá-los em sua essência. O terceiro período, de 1998/1999, em que a PROGRAD apresentou proposta de Regulamento Geral dos Cursos de Graduação da UFG (RGCG), introduzindo novos parâmetros

curricular, tendo em vista, as novas diretrizes curriculares a serem encaminhadas pelo MEC" (UFG. Reitoria, 2000: 11).

171 A Comissão englobou a discussão do regime acadêmico e dos currículos plenos em um único instrumento. Além disso, tratou de assuntos que não constavam das resoluções anteriores, ou seja: a) da seleção, do ingresso, da oferta de disciplinas, da matrícula e do trancamento de matrícula; b) do calendário acadêmico, dos programas e dos horários de aulas; c) da verificação da aprendizagem, da freqüência e do aproveitamento de estudos; d) da exclusão de alunos; e) do tratamento especial; f) do histórico acadêmico; g) da conclusão do curso; h) da colação de grau; i) do regime disciplinar do corpo discente e da proibição do trote; j) das disposições finais. (Na análise dessa ârea, esses assuntos não serão destacados diretamente).

172 Of. Circular no 2, de 30 de abril de 1999, da Comissão designada para elaborar proposta do Regulamento Geral dos Cursos de Graduação da UFG. 
para definição do núcleo de formação dos currículos plenos, o que significa que a UFG não antecipou as mudanças curriculares (como fizeram algumas IES), nem esperou que o MEC e o $\mathrm{CNE}$ estabelecessem as diretrizes curriculares.

O exame das Resoluções CCEP/Cepec, que disciplinam os currículos dos cursos de graduação (anexo 7), no que tange às alterações curriculares efetuadas, evidenciam o significado, para a UFG, da reforma dos currículos plenos e do regime acadêmico, ocorrida em 1983/1984, na qual se verifica:

a) cerca de $20 \%$ dos cursos sofreram a última reforma curricular na década de 80, ou seja, após as mudanças introduzidas em 1983/1984, dentre os quais estão: Farmácia, Ciências Biológicas, Medicina, Ciências Sociais, Relações Públicas, Radialismo, Biblioteconomia;

b) cerca de $44 \%$ dos cursos fizeram modificações curriculares na primeira metade da década de 90, especialmente em 1992: Agronomia, Medicina Veterinária, Odontologia, Ciências da Computação, Educação Física, Física, Matemática, Química, Filosofia, História, Pedagogia, Geografia, Educação Artística, Letras;

c) cerca de $34 \%$ dos cursos já fizeram mudanças curriculares na segunda metade da década de 90, especialmente 1997 e 1998: Enfermagem, Nutrição, Direito, Jornalismo, Publicidade e Propaganda, Artes Visuais, Música, Design de Moda, Engenharia Civil, Engenharia Elétrica, Engenharia da Computação.

Os elevados percentuais de modificações e alterações curriculares, na segunda metade da década de 90 , não denotam grandes mudanças, pois, em geral, foram feitos pequenos ajustes disciplinares, especialmente no deslocamento, introdução ou retirada de disciplinas. Alguns currículos foram modificados por ocasião da criação de novas unidades acadêmicas, em razão do novo Estatuto e Regimento, em 1996. Registra-se, também, a criação de novos cursos (Design de Moda, Publicidade e Propaganda, Engenharia de 
Alimentos, Artes Visuais, Musicoterapia etc) com os seus devidos currículos plenos, o que, contudo, não significa reforma curricular.

A análise das resoluções, que instituem os currículos plenos dos cursos de graduação (anexo 7) evidencia, também, uma total adesão à reforma curricular de 1983/1984, como demonstrado nas resoluções que alteraram os currículos. Houve, ainda, uma ampla disposição do corpo docente, naquele momento, para constituir novo projeto de graduação da $\mathrm{UFG}^{173}$. A reforma de currículo de 1989 obteve uma adesão parcial, pois não promoveu grande inovação. Boa parte dos cursos mantiveram a estrutura curricular anterior, já que não havia muito o que mudar, enquanto aqueles que implementaram alterações, não o fizeram imediatamente, como ocorrera no período anterior, o que está evidenciado até na análise da resolução curricular dos cursos, ocorrida por ocasião da avaliação institucional da UFG, em 1996174. A maior parte das alterações nos currículos plenos, desse período, ocorreram em 1992. Após a primeira metade da década de 90, registram-se mudanças pontuais e de pequeno porte em alguns cursos.

De um modo geral, a comparação entre o Regulamento Geral dos Cursos de Graduação - 1999 (UFG. Prograd, 1999b) ${ }^{175}$ e as duas reformas curriculares anteriores (1983/1984 e 1989), no tocante aos princípios e aos critérios orientadores (anexo 8), evidencia que:

\footnotetext{
173 Nesse sentido, é preciso lembrar que a primeira metade da década de 80 foi marcada pela luta contra o Regime Militar, pela retomada da democracia e pela luta contra o projeto de universidade que era implantado desde a Reforma Universitária de 1968, o que permitiu uma consciência mais unificada quanto aos rumos da universidade. A implantação do regime seriado anual, em substituição ao de créditos em regime semestral, e a afirmação de princípios como integração do ensino e da pesquisa à realidade, definição de perfil profissional, núcleo epistemológico do curso, permitiram aglutinar forças.

174 A avaliação da graduação, realizada pela Comissão de Avaliação Institucional (UFG/PRODIRH, 1997), por ocasião do Paiub 1996, levantou os problemas, as críticas e as sugestões de alteração mais comuns à Resolução no $184 / 83$ e ao regime seriado. Ainda em 1996, foi constituída uma Comissão (Portaria no 3.168/96, ratificada pela Portaria $\mathrm{n} 0$ 3.396/96) com a finalidade de apresentar estudos para solucionar os problemas e dificuldades inerentes ao regime acadêmico, cujo resultado, em geral, reafirma os princípios daquelas resoluções e, por isso, enfraquece a idéia de reforma curricular.

175 A votação do Regulamento Geral dos Cursos de Graduação foi encerrada na Câmara de Graduação/Cepec em 29 de novembro de 1999, sendo possível que o Cepec altere o Regulamento.
} 
a) proposta atual não estabelece princípios curriculares orientadores, como nas resoluções anteriores;

b) ampliam-se, consideravelmente, a flexibilidade na elaboração dos currículos plenos e o grau de liberdade na definição dos projetos de cursos;

c) não se menciona o núcleo epistemológico;

d) substitui-se o regime seriado anual pela semestralização, com o minimo de cem dias letivos;

e) ocorre a flexibilização do processo ensino-aprendizagem, adotando-se uma concepção mais abrangente de currículo, enfatizando o projeto de cada curso;

f) os currículos mínimos desaparecem da composição dos currículos plenos;

g) enfatiza-se o estágio, que até passa a contar com uma Coordenação na Prograd/UFG;

h) o aluno adquire maior liberdade na composição do seu currículo, podendo cursar disciplinas fora do seu curso ou área de formação;

i) a matrícula passa a ser efetivamente por disciplina, observando-se os respectivos pré-requisitos;

j) não se estabelece uma carga horária máxima para as Atividades Complementares.

Como se vê, o Regulamento Geral dos Cursos de Graduação não tem a pretensão de manter o espírito das resoluções curriculares anteriores. $\mathrm{Na}$ prática, o Regulamento rompe duas pilastras das propostas estabelecidas: o regime seriado anual e o núcleo epistemológico, pelo menos na sua amplitude (considerada excessiva pela Prograd). Por esse motivo, provocou grande resistência às mudanças sugeridas na Câmara de Graduação e na 
universidade, em geral ${ }^{176}$. Para que o Regulamento fosse aprovado, a Câmara estabeleceu longo cronograma de debate e votação.

Além disso, objetivando diminuir as resistências, a Prograd elaborou um documento intitulado para entender o RGCG (UFG. Prograd, 1999a), em que discorre sobre os principais entraves à sua aceitação e aprovação. Dentre eles, procura mostrar os pontos centrais do novo Regulamento:

a) não há risco de retorno ao sistema de créditos, entendido como uma unidade de medida para atividades acadêmicas; ocorre que a disciplina torna-se elemento central do processo de formação, tornando-se nucleadora do processo ensino/aprendizagem;

b) a matrícula por disciplina também já ocorria no sistema seriado, embora, na maioria das vezes, fosse feita em um bloco determinado;

c) não acaba a seriação por disciplinas, uma vez que permite aos cursos dispor as disciplinas do Núcleo Comum e do Núcleo Específico em uma seqüência fixa, baseada em pré-requisitos;

d) a semestralização na administração das atividades acadêmicas, dentre outros fatores, diminui a rigidez do curso, facilita a vida de professores e alunos, possibilita a integração da UFG com outras IES e não acarreta aumento da carga horária do curso, ou expansão do corpo docente, ou acréscimo de trabalho burocrático;

e) não ocorre aumento de tempo para conclusão dos cursos.

176 Dentre os principais problemas arrolados por alguns dos membros da Câmara de Graduação estavam: a) pouco tempo de discussão da proposta; b) adoção de um novo receituário do MEC; c) discordância com a volta do regime de crédito e com a matrícula por disciplina; d) aumento de gastos com a semestralização das atividades; e) liberdade quase total para elaboração das grades curriculares por parte dos cursos; f) descontrole acadêmico (sic). 
A argumentação da Prograd foi suficientemente convincente para que a Câmara de Graduação deliberasse favoravelmente ao RGCG ${ }^{177}$, no entanto, a história da UFG, nas duas últimas décadas, não demonstra que os cursos, de um modo geral, realizarão os ajustes curriculares, especialmente adotando a filosofia curricular, proposta do novo Regulamento para os cursos de graduação. Ao que parece, a elevada flexibilização proposta pode esbarrar em questões não consideradas e que, provavelmente, concordam com uma visão de sociedade e de homem, com um determinado projeto políticopedagógico, bem como com representações e práticas docentes fortemente consolidadas na instituição ${ }^{178}$.

\section{O movimento na área de pesquisa e pós-graduação}

Na UFG, o movimento na área de pesquisa e pós-graduação articula-se amplamente com a redefinição da missão ${ }^{179}$ e da identidade institucional e com a busca de alternativas de solução para os problemas vivenciados pela instituição, embora possa ser considerado bastante distinto em relação aos demais. Essa compreensão só se tornou possivel com base na observação sistemática da problemática, da dinâmica e no processo de tomada de

177 O Regulamento é constituído de 51 artigos e dois anexos

$178 \mathrm{Em}$ virtude de problemas de tramitação que inviabilizaram o início da votação do Regulamento, em 29 de maio de 2000, a Câmara de Graduação solicita oficialmente ao CEPEC que: "a) seja reconhecido o importante e histórico papel da Câmara de Graduação, bem como o seu direito/dever regimental de elaborar e apresentar a proposta do RGCG da UFG; b) seja reconsiderada a decisão da última reunião conjunta Consuni/Cepec em que, contrariando frontalmente normas estatutárias, foi ilegalmente constituída uma Comissão para elaborar nova proposta de Regulamento; c) seja apreciada no Cepec, ainda que daí resulte a sua rejeição, a proposta laboriosa e honestamente discutida e aprovada por esta Câmara; d) seja, em suma, dado ao regulamento o encaminhamento determinado pelas normas do Estatuto e do Regimento em vigor na UFG" (UFG. Prograd, 29 mai. 2000). Até o final de julho de 2000, o Regulamento não tinha sido votado no Cepec, em razão da resistência de inúmeros conselheiros, sobretudo, dos diretores das unidades acadêmicas da UFG, à sua aprovação.

$179 \mathrm{O}$ termo missão tem sido amplamente utilizado nos documentos das Ifes. Na UFG foi adotado pela gestão que iníciou em 1998. De acordo com o Plano de Gestão 1998-2001, a missão da UFG é "gerar, sistematizar e socializar o conhecimento e o saber, formando 
decisão na área. O trabalho de investigação também permite ordenar o movimento da área em quatro temáticas bastante significativas, ou seja: a) as peculiaridades constitutivas; b) as pressões e tensões existentes; c) a problemática do controle e gerenciamento; d) as estratégias de consolidação, investimento e reconhecimento. Os limites dessas temáticas são bastante tênues, pois estão interrelacionadas no movimento da área, o que dificulta tratá-las separadamente. Mesmo assim, objetivando oferecer maior compreensão, optou-se por uma exposição mais segmentada.

\subsection{Peculiaridades constitutivas da área}

O movimento nessa área indica que está em curso a formação de uma consciência, pelo menos no âmbito da pós-graduação, de que, sem a consolidação da pesquisa e da pós-graduação stricto sensu, a UFG encontrase ameaçada como universidade, cujo projeto consiste em destacar-se como centro de produção do conhecimento. Há entendimento de que as agências de fomento, como a Capes e o CNPq, estão deixando de apoiar, paulatinamente, os programas de mestrado, para investir, tão somente, nos programas de doutorado. Por isso, adquire força a idéia de que " $a$ consolidação da UFG passa, necessariamente, pela instalação de programas de doutorado, a partir do fortalecimento dos mestrados existentes"180. Em outras palavras, a conquista da legitimidade científica está associada à consolidação da pesquisa e pós-graduação stricto sensu, em nível de doutorado.

A compreensão da necessidade de investir nos cursos de doutorado, especialmente para fomentar a produção científica na instituição e possibilitar o surgimento de uma nova identidade institucional, esbarra em

profissionais e individuos capazes de promoverem a transformação e o desenvolvimento da sociedade" (UFG, 1998b: 9).

180 Comentário de membro da Câmara de Pesquisa e Pós-Graduação, em reunião do dia 27 de maio de 1999. 
dois problemas claramente identificados, no caso da UFG. Primeiro, a existência de 17 cursos de mestrado e apenas um de doutorado, em 1999, indica que são insuficientes os esforços institucionais, sobretudo da administração superior da universidade e da Capes para apoiar a instalação de cursos de doutorado. Essa constatação baseia-se em duas evidências: alguns mestrados existentes, criados nas décadas de 70 e 80 , já se encontram bastante consolidados; outras Ifes, do mesmo porte da UFG e com percentual semelhante de doutores, já possuem número bastante relevante de programas de doutorado.

O segundo problema relativo a essa consciência e a esse projeto da área refere-se à forte identificação histórica da universidade com a formação de profissionais, em nivel de graduação, expressa na grande ênfase que se imprime à expansão das vagas e dos cursos nesse nível de ensino, bem como à ampliação da prestação de serviços, que a transforma em uma universidade voltada mais para a formação de recursos humanos, objetivando o mercado de trabalho.

A priorização das atividades de ensino em graduação, em detrimento da pós-graduação stricto sensu, ainda é uma realidade na instituição, especialmente no momento da distribuição da carga horária de aulas (no início de cada ano letivo). A carência de professores faz com que, em muitas unidades acadêmicas, primeiro se distribua a carga horária da graduação e, depois, a da pós-graduação. Essa situação agrava-se pelo fato de que a orientação de alunos da pós-graduação não é contada como aula, para efeito da GED ${ }^{181}$, o que sacrifica e desestimula os professores que atuam na pósgraduação ${ }^{182}$.

\footnotetext{
181 Essa análise refere-se à GED implementada em 1998 e que vigorou até o final de 1999. É possível que modificações tenham sido feitas para alterar a pontuação da orientação, em nível de pós-graduação, objetivando a GED 2000.

182 O crescimento do número de doutores na instituição e de professores cursando doutorado indica que o conflito tende a tomar outros rumos, pois aumenta o volume de trabalho na área, a importância e o interesse pela pós-graduação e pela pesquisa.
} 
Esses problemas, no entanto, não impedem que a área de pósgraduação e de pesquisa constitua-se em um mundo a parte na instituição, sobretudo no tocante à agregação de valores, discursos, condutas e práticas comuns. Nessa área, observa-se um movimento mais coeso em torno de finalidades comuns, em relação ao projeto de universidade, sendo curioso que ocorra exatamente em uma área em que existe maior acúmulo de capital intelectual que, em geral, se encontra em disputa, mesmo no que diz respeito à ocupação de postos de poder na universidade e fora dela. As fragilidades existentes e as dificuldades encontradas parecem estimular uma maior agregação da área, que se vê como capaz de criar as condições para a UFG poder competir no campo universitário, para o que se mobiliza mediante estratégias de consolidação, investimento e reconhecimento ${ }^{183}$, em que pesem as pressões, tensões e disputas naturais do setor na instituição.

\subsection{As pressões e tensões existentes}

A área de pesquisa e pós-graduação está submetida a uma grande pressão externa, especialmente das agências financiadoras, avaliadoras e controladoras. Nesse sentido, a Capes e o CNPq podem ser consideradas instâncias modeladoras do comportamento da pós-graduação, já que induzem politicas, formas e mecanismos de avaliação e de gestão. A Capes, responsável pela avaliação da pós-graduação, promove um tipo de enquadramento que concorre para o estabelecimento de certo comportamento institucional $^{184}$ determinando, em grande parte, o modo de ser e de agir na área.

\footnotetext{
183 Essas estratégias nem sempre aparecem de uma maneira muito clara na pós-graduação, e se expressam, muitas vezes, nas tomadas de posição diante dos problemas, na improvisação ou na busca de alternativas inovadoras de solução, nas discussões da área, nas frentes de trabalho propostas pela Pró-Reitoria, em busca de fontes de financiamento para os projetos etc.

${ }_{184}$ Expressões usadas em reunião da Câmara de Pesquisa e Pós-Graduação, ocorrida em 22 de abril de 1999.
} 
São diversos os meios e as formas de pressão das agências de financiamento e avaliação da pós-graduação. Uma delas é a redução dos recursos financeiros, das bolsas e dos programas de apoio à pesquisa e à pós-graduação, como por exemplo os cortes orçamentários, reduzindo as bolsas existentes ou impedindo a aquisição de bolsas novas, bem como os constantes embates com a Capes, em torno dos recursos do Programa de Apoio à Pós-graduação (Proap) para os programas de pós-graduação da UFG185. Esses recursos são fundamentais para a manutenção e funcionamento dos programas. Os problemas agravaram-se, em 1998, quando a Capes anunciou o corte de recursos para pagamento das taxas acadêmicas dos alunos, o que passou a vigorar no ano seguinte. Ela entende que o Proap já paga essas taxas, então seus bolsistas não precisam pagá-las. Esse entendimento força uma tomada de posição na área, pois os programas só poderiam cobrar taxas acadêmicas dos não-bolsistas, ou seja, exatamente daqueles que já não possuem o beneficio da bolsa ${ }^{186}$.

A questão é extremamente relevante, porque, atualmente, os recursos financeiros obtidos mediante os cursos de mestrado e doutorado da instituição, especialmente do Proap/Capes, tornaram-se fundamentais para a manutenção e desenvolvimento dos cursos. "As unidades que têm esses recursos estão em situação menos sofrivel dos que as que não têm"187. Essas unidades acadêmicas, em geral, também realizam maior volume de pesquisa, razão porque a administração superior da universidade, que considera as potencialidades dessa área como geração de recursos, solicita "que os professores se empenhem em projetos de boa qualidade na busca de recursos

\footnotetext{
185 Além disso, há uma enorme pressão para reduzir o tempo de conclusão dos cursos de pós-graduação stricto sensu. A UFG diminuiu para três anos o tempo de licença para doutorado e para dois anos a de mestrado, tornando esse tempo de licença improrrogável.

186 Essa questão foi amplamente debatida na Oficina de Trabalho para os coordenadores de programas de pós-graduação stricto sensu da UFG, ocorrida em 23 de abril de 1999, sem que se tenha chegado a uma decisão.

187 Comentário de um conselheiro na Reunião do CEPEC, realizada em 16 de março de 1999.
} 
para a instituição". Além da pesquisa, sugere-se também o intercâmbio internacional "como forma de financiamento alternativo da UFG" 188.

Uma outra forma de pressão, modeladora da área, trata-se da criação, pela Capes, do Programa de Estágio de Docência na Graduação, em 1999, que exige que os bolsistas do Programa de Demanda Social realizem atividades de ensino nos cursos de graduação. O estágio docente passou a ser uma cláusula obrigatória nos convênios com a Capes, condicionando a liberação de bolsas. Também, encontra-se articulado, em cada unidade acadêmica, ao programa de pós-graduação, objetivando a formação do bolsista pósgraduando e o seu aproveitamento no sistema de ensino superior brasileiro ${ }^{189}$. No processo de implementação do estágio de docência na graduação ${ }^{190}$, a Capes determina o cumprimento das seguintes diretrizes: a) o estágio constitui parte integrante da formação dos pós-graduandos; b) deve ser realizado sem prejuízo do tempo de titulação do bolsista; c) tem a duração de um semestre para o bolsista do mestrado e de dois semestres para o de doutorado; e c) deve ser supervisionado pelo orientador do bolsista.

O processo de discussão para implementação do Programa de Estágio de Docência na Graduação, na UFG191 provocou algumas questões inevitáveis: o estágio seria uma forma de promover ainda mais a formação dos pós-graduandos e de integrar a graduação à pós-graduação, como afirma a Capes, ou funcionaria como um paliativo à falta de professores, em virtude da não-liberação das vagas para concurso público? O estágio diminuiria o empenho da administração superior da universidade na reposição de professores, pela contratação de docentes substitutos? Os recursos utilizados

188 Declarações do Pró-Reitor de Pesquisa e Pós-Graduação, em reunião da Reitoria Itinerante, registrada pelo Diário da Manhã (1999: 5).

189 Of. Circular no 28/99/PR/Capes, de 26 de fevereiro de 1999 (Brasil. MEC/Capes, 1999).

190 Anexo ao Of. Circular no 28/99/PR/Capes, de 26 de fevereiro de 1999 (Brasil. MEC/Capes, 1999).

191 O Estágio de Docência para alunos de pós-graduação stricto sensu da UFG foi regulamentado pela Resolução Cepec no $472 / 99$. 
com o pagamento de professores substitutos tenderiam a diminuir com o programa de estágio?

Essas preocupações são compreensíveis na UFG, uma vez que aumentou bastante o contingente de professores substitutos contratados nos últimos anos. Para se ter uma idéia, para o ano letivo de 1999, até maio daquele ano, foram contratados 124 professores substitutos, o que corresponde a mais de $10 \%$ do corpo docente da instituição. Para o ano 2000, as unidades acadêmicas solicitaram 190 professores substitutos, o que demonstra uma precarização no atendimento das atividades de ensino de graduação, motivada não só pelo contingente de professores do quadro efetivo que não foram contratados, mas também pelo baixo nível de titulação e qualificação dos professores substitutos que ingressam na instituição. Pode-se dizer que será muito grande a tentação em utilizar os bolsistas na regência de sala, assumindo integralmente algumas disciplinas ${ }^{192}$.

Um outro exemplo desse processo de readequação da área de pósgraduação encontra-se na criação do Programa de Bolsas para os cursos stricto sensu da UFG, regulamentado pela Resolução Cepec no 446/99, o que implicou a extinção do Programa de Bolsas de Monitoria da Pós-Graduação. A avaliação da área considerou necessária essa mudança por causa de: a) carência de recursos; b) necessidade de bolsas para os programas de pósgraduação stricto sensu; c) qualidade e produtividade das bolsas de monitoria de pós-graduação; d) valor precário das bolsas de monitoria. ${ }^{193}$. A Pró-Reitoria de Pesquisa e Pós-Graduação acredita que a mudança resultaria em aumento na produtividade dos alunos, já que o aluno tem que prestar serviços em sua unidade. Em 1999, os recursos foram suficientes para oferecer 15 bolsas, cujos valores e critérios de seleção estabelecidos para sua obtenção são semelhantes aos da Capes, todavia, há maior exigência no desempenho do

192 Essa situação ocorria concretamente, em abril de 1999, em algumas unidades acadêmicas da UFG.

193 Ata da Sessão Extraordinária do Cepec, p. 3, realizada em 16 de abril de 1999. 
aluno, que deve apresentar relatório semestral à Coordenação de PósGraduação, objetivando seu acompanhamento, e do qual devem constar informações sobre as atividades realizadas e os resultados do trabalho em cada fase.

Como se pode observar até aqui, o movimento na área de pósgraduação, que expressa demandas externas e internas, acontece em um clima de tensão e de pressão, o qual, no entanto, parece mais fruto da necessidade de permanente mudança do que de uma resistência deliberada aos processos e medidas de ajuste do setor ${ }^{194}$. A disposição da área parece caminhar em direção às inovações, mesmo correndo o risco de fazer o jogo das forças de ajuste do setor.

Um bom exemplo dessa compreensão evidencia-se com o surgimento, na UFG, de propostas de cursos de mestrado profissionalizantes, ou seja, programas voltados para a aplicação de profissionais no mercado de trabalho. Em algumas áreas, especialmente aquelas ligadas mais diretamente ao mercado de trabalho, esse tipo de mestrado tende a se expandir na instituição, já que acentua o desenvolvimento tecnológico de ponta em uma área profissional. Esse tipo de programa substitui o caráter acadêmico de formação do docente pesquisador pela formação de profissional habilitado em uma técnica, em uma tecnologia.

A Capes incentiva a expansão dos mestrados profissionalizantes, que surgiram sob o manto do maior relacionamento universidade-empresa. A empresa precisa formar profissionais qualificados, a baixo custo, e o faz mediante essa forma de articulação. A possibilidade da empresa injetar dinheiro nos programas, bem como absorver a mão-de-obra formada torna-se bastante atraente, no entanto, uma das questões problemáticas é exatamente a idéia de que os cursos dessa modalidade possuem vocação para

194 Nesse contexto, também, foi instituído o programa especial para participação voluntária de docentes aposentados nas atividades de ensino de pós-graduação, pesquisa, extensão $e$ cultura na UFG (UFG. Resolução Cepec no 476/99). 
o autofinanciamento (Portaria MEC, no 80, de 16 de dezembro de 1998). O MEC concebe a idéia de que esse aspecto deve ser explorado para iniciativas de convênio com vistas ao patrocinio de suas atividades (art. 60). Significa que as instituições que criarem essa modalidade de programa não terão ajuda da Capes para manter a gratuidade? O que ocorrerá com os programas que possuem vocação basicamente acadêmica? São essas algumas das questões que preocupam a área de pesquisa e pós-graduação da UFG.

O Mestrado Profissionalizante em Radiologia Bucomaxilofacial da Faculdade de Odontologia (FO) foi o primeiro curso dessa natureza aprovado na UFG, em abril de 1999. A criação do curso de mestrado, no entanto, representou uma ação bastante distinta da esperada, já que significou para a PRPPG uma forma de democratização de uma área bastante elitizada, uma vez que os cursos de especialização, na área de Odontologia, foram os primeiros a cobrar mensalidades na universidade ${ }^{195}$. A criação do mestrado gratuito foi considerada uma atitude democrática exatamente porque não parecia haver interesse na oferta de cursos de pós-graduação gratuitos. $O$ Pró-Reitor de Pesquisa e Pós-Graduação justifica que há uma demanda de "profissionais carentes que não podiam pagar os cursos de especialização e que, portanto, aguardavam programa stricto sensu, gratuito na instituição" (UFG. Ata do Cepec, 6 abr. 1999). Ele informa, ainda, que se trata de um programa também significativo para a UFG, não só pela criação do espaço e conteúdo acadêmico-profissional, mas também pelo fato de que, na área de Odontologia, há enorme demanda para cursos dessa natureza.

No bojo das contradições e das estratégias de inovação, ganha espaço o mestrado profissionalizante na UFG. Os programas mais vinculados à produção de novas tecnologias, produtos e serviços para o mercado de trabalho parecem mais atraídos pelas possibilidades de fortalecimento, com base em uma maior caracterização profissional dos pós-graduandos. Os

195 Em geral, as mensalidades dos cursos de especialização na área de Odontologia ultrapassam $\mathrm{R} \$ 1.000,00$. 
novos programas de mestrado já assumem a dupla identidade acadêmicoprofissional, como por exemplo, o caso do Mestrado em Química, que teve início em 1999.

Além desses casos, dois outros problemas são típicos de uma universidade com o perfil apresentado pela UFG e em processo de metamorfose. O primeiro diz respeito à questão do atrelamento da pesquisa à vocação e demandas regionais, cuja discussão surgiu com base na institucionalização do Programa Regional Integrado de Pesquisa e Extensão (Pripe), apoiado pelo Ministério de Ciência e Tecnologia, que tinha por objetivo promover a capacitação voltada ao desenvolvimento tecnológico. $\mathrm{O}$ Pripe, implementado na gestão 1994-1997, apresentou-se como prioritário e aglutinador das atividades de pesquisa, o que produziu uma reação contrária da comunidade de pesquisadores da instituição, especialmente da área de Ciências Humanas. Para muitos professores, o Pripe era uma camisa de força, que amarrava os projetos de pesquisa da instituição ${ }^{196}$. Discordava-se desse tipo de projeto por considerá-lo medida de enquadramento, de aprovação e de financiamento dos projetos de pesquisa na universidade. $\mathrm{O}$ julgamento era do tipo o que esse projeto tem a ver com o cerrado? Caso não houvesse identificação com o programa guarda-chuva, os projetos não logravam aprovação.

O Pripe pode, em grande parte, ser interpretado como uma forma de atendimento às agências financiadoras, como o CNPq e a Financiadora de Estudos e Projetos (Finep) ${ }^{197}$. Essas e outras agências de fomento investem em iniciativas de caráter regional, acarretando o atrelamento da pesquisa e da extensão às demandas do contexto local e regional. Esse apoio,

\footnotetext{
196 Depoimentos assim foram feitos em diferentes reuniões da Câmara de Pesquisa e PósGraduação do Cepec.

197 Projetos como o Pripe deverão continuar no horizonte da UFG. Dentre as novas propostas apresentadas pelo novo presidente da Funap, empossado em janeiro/2000, está a elaboração de "projetos de pesquisa integrados, ou seja, projetos induzidos conforme a demanda de uma determinada necessidade, principalmente em função dos interesses de desenvolvimento do Estado de Goiás" (Gente nova na Funap. Diário da Manhã, 2000: 3).
} 
evidentemente, atrai e seduz boa parte dos pesquisadores da instituição. Resta saber, no entanto, se essas forças regionalizantes serão determinantes na produção do trabalho acadêmico, a ponto de subjugar as forças dos agentes intelectuais de caráter mais universalizante.

As pesquisas produzidas na UFG e a reação contrária à camisa de força de políticas que priorizem, em especial, o regional, levam a crer que a comunidade intelectual da universidade, formada em diferentes e grandes centros de pesquisa ${ }^{198}$ possui capital intelectual para sobrepujar as amarras do regionalizante. Em uma sociedade globalizada, o local e o regional ganham enorme importância, mas torna-se praticamente impossivel não haver redes de comunicação com o conhecimento produzido pela comunidade nacional e internacional, o que parece ser, atualmente, a referência imperativa da maioria dos pesquisadores da UFG, o que pode impedir o tipo de ajuste que se vem tentando fazer ${ }^{199}$.

É preciso levar em conta que o aumento do número de convênios e de projetos de prestação de serviços à comunidade implica situação bastante curiosa na redefinição da universidade. Por um lado, os convênios e os projetos têm o mérito de integrar a universidade, sobretudo, à comunidade local e regional, bem como torná-la mais relevante na resolução dos problemas ${ }^{200}$. Assim, a universidade passa a refletir a cultura local e regional e a ganhar maior relevância no seu contexto, cuja vivência também permite que a universidade entre em contato com uma dada realidade, tornando-se

\footnotetext{
$198 \mathrm{Na}$ análise dos processos de afastamento para cursar pós-graduação stricto sensu, especialmente doutorado, verifica-se que a maioria dos professores da UFG estão em grandes universidades do país (USP, UFRJ, Unicamp, UFMG etc) ou mesmo do exterior.

$199 \mathrm{Em}$ virtude dessa situação, seria interessante analisar a hipótese de que o maior volume de recursos para a pesquisa regional, desde que não fosse destinado exclusivamente a uma área de conhecimento, poderia consolidar a universidade como centro de pesquisa, sem subordinar ou regionalizar a investigação científica.

200 Atualmente, crescem a prestação de serviços remunerados e o número de convênios estabelecidos com os municípios goianos, em razão sobretudo da crescente demanda por serviços e projetos mais qualificados de desenvolvimento municipal e das novas exigências na aplicação dos recursos públicos.
} 
co-formuladora ${ }^{201}$, portadora e transmissora de uma cultura local e regional. Nessa direção, a missão fundamental da universidade define-se pelo contexto local e regional, para formar profissionais, estudar e intervir nos problemas, além de contribuir para o avanço do conhecimento e da cultura local e regional. Por outro lado, a universidade, no contexto da mundialização produtiva e financeira, corre o risco de perder contato com o universal, especialmente na formação de profissionais, na produção de conhecimento e na formulação de uma cultura brasileira.

O segundo problema identificado diz respeito à polêmica entre projetos de pesquisa individual versus projetos de núcleos ou grupos de pesquisa, envolvendo duas questões. De um lado, as agências de fomento privilegiam, no discurso e na prática, o trabalho de grupos de pesquisadores, o que significa uma pressão externa para que os projetos sejam interdisciplinares e multidisciplinares. De outro, a UFG exige que os professores (mestres e doutores), com dedicação exclusiva, estejam realizando pesquisa. No primeiro caso, observa-se que a tradição da UFG, ainda se concentra na pesquisa individual. Ainda são poucas as pesquisas ou atividades interdisciplinares, embora seu número esteja crescendo rapidamente. Há consenso, todavia, que essa nova forma de investigação seja incentivada na instituição, no entanto, deve ser um processo natural. Não se devem privilegiar os projetos individuais ou de grupos, como estão fazendo as agências de fomento, já que as situações são as mais variadas ${ }^{202}$. Acredita-se que, em algumas áreas, o trabalho individual é muito produtivo. No segundo caso, observa-se o crescimento das atividades de pesquisa na instituição, mas também o aparecimento de projetos, registrados em departamento, os quais não são levados a efeito, bem como o aumento nominal de docentes envolvidos em um único projeto.

201 Muitas dessas formulações estabelecem vinculos e acordos políticos com os governos e politicos locais, o que não deixa de ser preocupante, uma vez que interfere direta ou indiretamente na tomada de decisão sobre os rumos da instituição.

202 Reunião da Câmara de Pesquisa e Pós-Graduação, realizada no dia 4 de março de 1999. 
Outro aspecto que merece destaque, como elemento de pressão e de tensão, refere-se à GED, que interfere diretamente na constituição do movimento da área, e que se dá de várias formas. Primeiro, atua como elemento de controle, uma vez que amplia o poder da PRPPG no cadastramento e estabelecimento de mecanismos de acompanhamento das atividades, projetos e produtos que serão ou não avaliados pela GED. Segundo, implementa uma hierarquia de atividades, de funções e de produtos de pesquisas que influencia no comportamento, nos hábitos e nas atitudes dos pesquisadores. Terceiro, impulsiona uma disputa interna entre as áreas de atuação da universidade e dos docentes: ensino, pesquisa, extensão e administração 203 .

\subsection{A problemática do controle e gerenciamento}

A questão da ampliação das formas de controle e gerenciamento da área de pesquisa e pós-graduação também pode ser apontada, atualmente, como uma das peculiaridades fundamentais de seu movimento constitutivo. Essa problemática está, também, amplamente ligada às pressões e às tensões existentes, bem como às estratégias de consolidação, investimento e reconhecimento da área.

Atualmente, verifica-se grande esforço da administração superior da instituição, em especial da PRPPG e da PRODIRH, na implementação de mecanismos de informação e controle que permitam melhor gerenciar a área, objetivando: dar respostas às solicitações das agências financiadoras e avaliadoras dos programas, bem como ao público em geral; promover a divulgação e o marketing dos cursos; ampliar o controle interno e promover a

203 Pode-se incluir o trabalho dos docentes nos sindicatos e associações que, segundo depoimentos, apresentaram baixo grau de reconhecimento na pontuação da GED1998. 
avaliação dos programas; obter elementos que facilitem a tomada de decisão, o planejamento e o estabelecimento de politicas na área ${ }^{204}$.

Esse esforço concretiza-se gradualmente, uma vez que existe na instituição grande autonomia dos programas stricto sensu, o que se deve, em parte, ao tipo de relacionamento que a Capes sempre manteve com os programas, o que, entretanto, parece estar mudando. No momento, a Capes busca maior articulação com as pró-reitorias de pesquisa, tanto do ponto de vista da administração de suas políticas como do controle e avaliação dos programas.

A Capes, ao que parece, está centralizando sua atuação nas universidades federais, produzindo efeitos, especialmente com o fim de levar, no caso da UFG, a PRPPG a estabelecer formas mais ágeis de gerenciamento, o que ocorreu em 1999, por exemplo: o início do desenvolvimento de Sistema de Pós-Graduação Stricto Sensu da UFG, que objetiva registrar a vida acadêmica dos alunos e dos programas, bem como permitir o acesso instantâneo às informações e a emissão de relatórios totalizadores por indicadores acadêmicos; a Regulamentação das Atividades de Pesquisa na UFG (UFG. Resolução Cepec no 462/99), que cria um sistema de cadastro e acompanhamento dos projetos de pesquisa, além de induzir à implementação de mecanismos de apoio ao acompanhamento e à avaliação, mediante mudanças normativas.

A regulamentação da execução de atividades de pesquisa visa permitir um maior controle dos projetos, o que tem uma razão de ser, já que, em 1998, havia mais de três mil projetos de pesquisa cadastrados na PRPPG. Dentre eles, alguns projetos não apresentavam data de início e término e havia um outro projeto, com início na década de 70 , em que não constava a data de conclusão. Baseando-se em informações constantes do Radoc, afirma

204 A variação no número de alunos em pós-graduação passou, também, a interferir no orçamento da universidade, por isso, a administração superior procura registrar melhor seus dados, uma vez que os recursos advêm desses números (declaração da Pró-Reitora de Administração e Finanças, em reunião do Consuni, em 9 novembro de 1999). 
o Coordenador de Pesquisa da Pró-Reitoria que 92\% desses projetos não têm financiamento, além de existirem projetos de extensão que foram cadastrados como projetos de pesquisa. O controle dos projetos de pesquisa visa também alimentar o Radoc que, por sua vez, vai sustentar a GED, prevalecendo a idéia de que só os projetos de pesquisa cadastrados na PRPPG devem ser computados para efeito de GED 205 .

A área demonstra também a preocupação de estabelecer processo de deliberação mais ágil206, objetivando agilizar as reuniões e permitir discussões de ações politicas e diretrizes que possam melhorar o desenvolvimento das atividades da área, bem como debater "problemas atuais e urgentes (autonomia, GED, Bolsa de Estágio de Docência da CAPES, avaliação e acompanhamento dos cursos de pós-graduação (...), politica de incentivo à criação de novos cursos de mestrado e doutorado etc.)" (UFG. Ata do CPPG/Cepec, 25 mar. 1999). Considerando que a maioria dos processos da Câmara dizem respeito à solicitação de afastamento para cursar ou concluir pós-graduação (especialização, mestrado e doutorado), à aprovação de relatórios parciais e finais de cursos de pós-graduação realizados, à aprovação de cursos de pós-graduação e regulamentos (regimentos, programas, grades curriculares etc.) e a processos de progressão docente e reconhecimento de título e gratificações, apresentou-se proposta de analisar os processos por meio de Câmaras Setoriais: Câmara Setorial de Qualificação, Câmara Setorial de Criação de Cursos de Pós-Graduação e Câmara de Revalidação e Reconhecimento de Título e Gratificações.

Outro exemplo da nova disposição de gerenciamento e controle pode ser vislumbrado na posição assumida pela Câmara de Pesquisa e PósGraduação quando foi solicitada, por uma unidade acadêmica da UFG, a

\footnotetext{
205 Essa idéia já se efetivou no processo da GED/2000.

206 Nesse sentido, foi apresentada proposta de aprimoramento do esquema de trabalho da Câmara, em 25 de março de 1999, em que o membro proponente faz uma análise dos processos, apresentando amostra com base nas atas de reuniões da CPPG/CEPEC.
} 
aprovação de Regulamento Interno da Coordenação de Pesquisa e Pós-

Graduação. Nessa discussão, a Câmara aprovou o seguinte:

1. A criação de uma Coordenação de Pós-Graduação se efetiva através da sua inserção no regimento Interno da Unidade e a regulamentação desta Coordenação é decisão final do Conselho Diretor; 2. As normas do Regulamento desta Coordenação devem obedecer à Legislação Superior vigente em nivel desta Universidade e das normas federais da matéria; 3 . O atual Regulamento (...) entra em confronto com estas normas citadas anteriormente, o que implica numa revisão cuidadosa do mesmo por esta Unidade acadêmica; 4. A criação de uma Coordenação de Pós-Graduação não dispensa a Unidade Acadêmica de apresentar aos órgãos competentes desta Universidade o projeto/Regulamento de cada programa de PósGraduação stricto sensu, que deverá atender obrigatoriamente a Legislação Superior sobre a matéria (UFG. Ata da CPPG/Cepec, 8 abr. 1999).

A necessidade de maior gerenciamento e controle, na área, encontra-se nos cursos de pós-graduação lato sensu, com duas situações. De um lado, os cursos novos, criados na perspectiva de nova organização e filosofia, incluem a cobrança de mensalidades, e de outro, os cursos antigos, os quais, mesmo incluindo-se a cobrança de mensalidades, funcionam regularmente sem se submeter à legislação da UFG, especialmente às Resoluções no 417/97 e no 2/97, e sem a preocupação de informar à PRPPG, em razão da tradição existente.

Segundo a Coordenadora de Pós-Graduação 207 , "o trabalho de adequação dos cursos de especialização está sendo feito aos poucos e a Câmara tem sido dura na observância das resoluções"208. Em parte, a ampliação do controle desses cursos vincula-se à nova sistemática de registro de diplomas, que inclui a assinatura do Pró-Reitor da área, e a exigência de planilha de custos que atenda à resolução da prestação de serviços remunerados na UFG (Resolução no 2/97). Essa planilha é solicitada, mesmo para os cursos que não cobram mensalidades, uma vez

207 Declaração da Coordenadora de Pós-Graduação, em reunião da Câmara de Pesquisa e Pós-Graduação, realizada em 8 de abril de 1999.

208 Segundo dados da PRPPG, em junho de 1999, havia 56 cursos de especialização na UFG, sendo: 17 regulamentados, 24 em processo de adequação ou com outros problemas e 13 sem informação. 
que "eles geram despesas para a universidade"209. Embora não exista cobrança de mensalidade, em alguns cursos, entende-se que cobrança da taxa de matrícula é uma forma de receita que deve ser dividida entre o fundo local e institucional210. Alguns membros da Câmara de Graduação mantêm idêntico raciocínio, ou seja, consideram que o mesmo sistema de fundos deve ser estendido à pós-graduação stricto sensu, no tocante aos recursos da matrícula e outros.

A Pró-Reitoria de Administração e Finanças retém os processos de cursos até que sejam sanados os problemas nas planilhas de custos, e os mais comuns são: o cálculo dos fundos local e institucional, o gerenciamento por fundações credenciadas pelo MEC, a diversificação das planilhas de custo e a ausência de elementos contábeis nas planilhas.

\subsection{As estratégias de consolidação, investimento e reconhecimento}

Em que pese a situação até aqui considerada, observa-se que as ações e reações, no interior desse movimento, buscam, em geral, firmar e potencializar a área da pesquisa e pós-graduação na UFG. Esse empenho e desejo, muitas vezes, concretizam-se sob a forma de estratégias de consolidação, investimento e reconhecimento da área. É evidente que essas estratégias, graças sobretudo à escassez de recursos financeiros ${ }^{211}$ e ao atual capital acadêmico da instituição no cenário nacional, tornam-se frágeis em suas possibilidades de planejamento, execução ou manutenção de determinadas posições.

\footnotetext{
${ }^{209}$ Reunião da Câmara de Pesquisa e Pós-Graduação, realizada em 27 de maio de 1999.

210 Segundo a Pró-Reitora de Administração e Finanças, a taxa de inscrição não entra como receita, porque precede o curso. Essa taxa serve para pagar as despesas com material de consumo e outras. Entende, também, que os recursos já retornam, de alguma forma, às unidades acadêmicas.

211 Segundo o Pró-Reitor de Pesquisa e Pós-graduação, a nova matriz de financiamento das Ifes, adotada pelo $\mathrm{MEC}$, destina $90 \%$ dos recursos ao ensino e apenas $10 \%$ à produção dos mestrados e doutorados. Por isso, entende que "as unidades que não possuem programas de pós-graduação stricto sensu devem se mobilizar, uma vez que o MEC só reconhece a produção nesses programas" (Reunião do Consuni, realizada em 9 de novembro de 1999).
} 
Essa fragilidade expressa-se, por exemplo, no papel da administração superior da universidade relativo à articulação e à indução de políticas de consolidação, investimento e reconhecimento da área. O debilitamento desse papel está certamente associado à lógica e à estratégia da política do governo federal para o setor, ou seja, à ampliação do controle da pesquisa e dos programas de pós-graduação, pelas pró-reitorias de pesquisa e pósgraduação, e, ao mesmo tempo, ao incentivo da competição particularizada dos grupos de pesquisa. Esse entendimento ganha sentido concreto, por exemplo, quando o Pró-Reitor de Pesquisa e Pós-Graduação da UFG afirma que "o setor de ciência e tecnologia tem caminhado graças à luta desenvolvida pelos grupos de pesquisa, que correm atrás do financiamento de seus trabalhos" (O Popular, 9 mai. 1999). Essa situação, associada à problemática do controle e gerenciamento, explicita o fato de que a Pró-Reitoria corre o risco de tornar-se, cada vez mais, uma extensão das agências de financiamento, controle e modelação da área ${ }^{212}$. Em que pese o risco, a análise desse movimento conclui que a PRPPG tem um importante papel na captação das aspirações e expectativas do setor, na organização, na formulação de projetos e na improvisação ou busca de soluções inovadoras, incluindo a ampliação dos mecanismos de controle, de gerenciamento e de avaliação.

$\mathrm{Na}$ UFG, essa problemática não pode ser vista fora da ótica das estratégias e das contradições presentes na área. A eficácia dos meios está na ordem-do-dia e parece tornar-se uma meta comum. A racionalização dos padrões de gestão na área indicam, pelos menos, duas finalidades, uma externa e outra interna. A primeira, externa, diz respeito à necessidade de

212 A questão do financiamento da pesquisa e pós-graduação coloca-se como um grande obstáculo às estratégias na área. Para a PRPPG, a discussão da autonomia universitária revela duas preocupações. De um lado, a pesquisa e a pós-graduação não entram nas propostas e na discussão da autonomia universitária realizada pelo governo federal. De outro, a Capes e o CNPq pretendem estabelecer novas formas de relacionamento com as Ifes. A Capes pretende repassar, a partir do ano 2000, a totalidade dos recursos do PICDT para cada Ifes para que administrem o montante global de recursos. 
otimizar os recursos destinados à instituição, mediante transferência global dos recursos, avaliação do desempenho dos programas e maior competição interna. A segunda, interna, refere-se à necessidade de permitir um melhor gerenciamento da área, fomentar políticas de consolidação e expansão dos programas levando a instituição a destacar-se nesse campo da atividade acadêmica, bem como constituir sua nova identidade ${ }^{213}$. Nessa direção, coloca-se a expansão qualitativa da área, especialmente com a criação de novos cursos de mestrado e doutorado ${ }^{214}$ e com a ampliação das fontes alternativas de financiamento dos projetos de pesquisa ${ }^{215}$.

Três niveis de atuação explicitam o empenho nessa direção:

a) a proposta de parceria entre a UFG, o CNPq e os governos do estado e dos municípios de Goiás para realização de Programa de Desenvolvimento Científico e Tecnológico, incluindo-se quatro plataformas negociadas: Agropecuária no Cerrado Goiano; Recursos Naturais e Energéticos, Biodiversidade e Gerenciamento Ambiental no Cerrado Goiano; Políticas Educacionais, Novas Tecnologias da Comunicação e Informação e trabalho no Estado de Goiás; Saúde Coletiva do Estado de Goiás. Além disso, a PRPPG empenha-se com as secretarias estaduais e as prefeituras, com o objetivo de apresentar às linhas de pesquisa da instituição, bem como de reconhecer as possibilidades de financiamento dos trabalhos e de

${ }^{213}$ Há fortes indícios de que já existe uma consciência acadêmica, pelo menos no âmbito da área de pesquisa e pós-graduação, com o objetivo de transformar a UFG num centro de pesquisa de excelência (Lima, 2000). Essa consciência vem se transformando em um esforço concreto de ação, é o que evidencia, por exemplo, a classificação das 12 melhores universidades brasileiras, efetuada pelo Instituto de Estudos Avançados da USP, no documento A presença da universidade pública, que coloca a UFG em 12으 lugar (USP. IEA, 2000: 3).

${ }^{214}$ Há um esforço nesse sentido, exemplificado na aprovação do Regulamento do Programa de Pós-Graduação Stricto Sensu em Educação Brasileira, que cria o Doutorado em Educação na Faculdade de Educação da UFG, e na instituição de doutorados interinstitucionais (UFG. Ata do Cepec, 4 mai. 1999).

215 A obtenção dos recursos para apoio à pesquisa ou o investimento nos programas de pósgraduação são cada vez mais competitivos e desiguais. Em 1999, por exemplo, a Capes anunciou um investimento nos laboratórios, cujos recursos seriam distribuídos, segundo dois indicadores: número de doutores e produção científica. A adoção desses indicadores significa, provavelmente, uma canalização dos recursos para as grandes universidades do país. 
constituição de uma agenda comum de ação, se houver interesse dos grupos e núcleos de pesquisa;

b) a luta pelo cumprimento, por parte do governo estadual, do ato constitucional que prevê o repasse de $3 \%$ da receita líquida do Estado para a área de ciência e tecnologia, assim como o apoio imediato aos projetos de pesquisa da instituição, já aprovados pela Secretaria de Ciência e Tecnologia;

c) a implementação de sistema de cadastro e acompanhamento das pesquisas na UFG, que compatibilize os esforços dos núcleos de pesquisa, incentive a criação de novos grupos e coloque o setor no mesmo nivel de prioridades de outras atividades acadêmicas na universidade.

Segundo declaração do Coordenador de Pesquisa da UFG, essas frentes, na verdade, expressam um entendimento mais amplo de que a viabilização dos

recursos para pesquisa passa por três caminhos: pressão ao governo federal para a manutenção do dinheiro da pesquisa, reivindicação, junto ao governo estadual, do cumprimento da lei estadual que destina parte do orçamento para a ciência e a tecnologia e a busca de parceiros junto à iniciativa privada (O Popular, de 9 maio 1999).

Externamente, a PRPPG adota a estratégia de buscar alternativas de financiamento e parcerias, em órgãos públicos ou privados, e, internamente, organizar e fomentar a área, especialmente os grupos e núcleos de pesquisa.

Além das estratégias e do empenho mais geral pela consolidação e reconhecimento, verifica-se que o movimento da área se define, em grande parte, com base nas necessidades cotidianas de sobrevivência das pesquisas e dos programas de pós-graduação. Nesse sentido, observa-se certo nível de improvisação de soluções ou mesmo de inovações que impulsionam a área e/ou conseguem promover uma atualização da cultura existente. O aprendizado cotidiano resulta da dinâmica produzida pelas condições estruturais, pelas ações dos agentes que atuam como elementos 
determinantes do movimento da área e pelas condições acadêmicas objetivas da instituição.

Cabe registrar dois exemplos característicos do processo de atualização forçada da cultura institucional. O primeiro diz respeito à assinatura de convênio entre UFG/Funap/UCG, objetivando o desenvolvimento de cooperação técnico-científica, em 1999. Em razão do pequeno número de bolsas e da aprovação de um contingente considerável de professores da UCG, para o mestrado de Engenharia Elétrica da UFG, a Coordenação do Programa propôs à UCG a assinatura de um convênio em que esta apoiaria financeiramente o mestrado, mediante repasse de recursos que seriam transformados em bolsas para alunos do programa, já que a instituição se beneficiaria com o aumento do número de mestres em seu quadro de docentes. A discussão para aprovação do convênio girou em torno da seguinte questão: esse tipo de convênio caracteriza uma doação ou a introdução disfarçada da cobrança de mensalidade para os cursos de pósgraduação stricto sensu da UFG? Prevaleceu o entendimento da ajuda de custo, considerando que os professores da UCG foram aprovados sem reserva de vagas e que não houve qualquer constrangimento em colaborar financeiramente com o Programa216. O segundo exemplo refere-se a um caso, relatado em reunião do Conselho Universitário (UFG. Ata do Consuni, 28 maio 1999: 6), de um aluno-empresário de um dos programas de mestrado, que, além de financiar sua própria pesquisa, de interesse de sua empresa, fazia doações ao laboratório do programa de mestrado ${ }^{217}$.

Esses exemplos demonstram que o processo de atualização do modus operandi da área leva ao surgimento de novas estratégias de sobrevivência dos programas de mestrado e da pesquisa na UFG. Observa-se, de um modo

\footnotetext{
216 O Convênio foi discutido em reunião do Consuni, ocorrida em 28 de maio de 1999. Vale registrar que já era executado há mais de um ano, quando de sua aprovação. Iniciativas semelhantes começam a surgir em outros Programas de Pós-Graduação stricto sensu da UFG.

217 Foram relatados também acontecimentos semelhantes, que ocorriam em outros programas de mestrado, especialmente naqueles mais ligados ao mercado do trabalho.
} 
geral, que o tempo-espaço de organização do movimento da área (expresso nos diálogos, nas declarações, nas posições e nos documentos) reconstituise, a cada momento, em razão das condições objetivas e das novas atitudes que são explicitadas e assumidas pelos integrantes da área. Surge com muita propriedade, por exemplo, no tratamento dispensado aos processos de afastamento de docentes para realizar cursos de pós-graduação ou prorrogação de afastamento, cujas exigências, rigor e controle são ampliados. Transparece, também, uma apreciação subjetiva do investimento acadêmicoinstitucional que se realiza, em que o juízo é formulado à luz das possibilidades de retorno do capital investido pela instituição. 


\section{CONSIDERAÇÕES FINAIS}

Este estudo teve o objetivo fundamental de examinar e de explicitar o estado de mudança que configura o processo de metamorfose das universidades públicas federais, tomando como referência básica o caso da Universidade Federal de Goiás (UFG). Observou-se, assim, a dinâmica que constitui as novas formas, feições e estruturas que estão se processando com o objetivo de transformar o modo de agir e de ser da instituição. Analisou-se como vem se equacionando a questão da natureza, da identidade institucional, do papel e da gestão dessa universidade ${ }^{218}$, no âmbito da reestruturação da educação superior decorrentes, em grande parte, das atuais políticas para esse nível de ensino e das tensões e desafios contemporâneos.

O trabalho adotou como ponto de partida a atual política de diversificação e diferenciação que vem reconfigurando o sistema de educação superior no Brasil, com base em um modelo que associa flexibilidade, competitividade e avaliação. Por sua vez, esse empreendimento reformista, que se articula na pluralidade e na diversidade dos interesses globais do capital, associadas a um projeto neoliberal de minimização do Estado, que corrobora as teses centrais e históricas do capitalismo-liberalismo concorrencial, exige uma correspondente mercantilização da educação superior, especialmente nos chamados paises periféricos. Nessa direção, as politicas de diversificação e diferenciação da educação superior acentuam cinco pressupostos fundamentais do neoliberalismo, quais sejam:

a) buscam favorecer a concorrência e o atendimento às diferentes demandas e clientelas, mediante oferta diversificada e diferenciada do nível superior, promovendo uma dissociação entre ensino e pesquisa;

\footnotetext{
${ }^{218}$ Incluem-se a concepção de saber, a ampliação da esfera pública, os compromissos sociais, a legitimidade social e acadêmica, a liberdade de produção do trabalho acadêmico e a luta pela emancipação social.
} 
b) procuram naturalizar, ainda mais, as diferenças individuais, instituindo paulatinamente um sistema meritocrático no qual cada um terá o ensino superior que possa ter;

c) ampliam a subordinação do ensino superior ao mercado, particularmente no tocante à formação profissional e à produção de bens e serviços acadêmicos;

d) explicitam mais a forma de funcionamento do sistema do que as suas finalidades sociais;

e) dão ao Estado os instrumentos legais e burocráticos necessários à avaliação e controle do sistema, o que permite promover uma maior competitividade.

Nesse contexto reformista, observa-se que as universidades federais com maior capital científico, intelectual e cultural procuram resolver os problemas e os conflitos atuais pela inovação, que visa melhorar a eficiência e eficácia na obtenção de produtos e processos gerenciais e comunicacionais, e da auto-afirmação da identidade institucional, centrada na cultura e na história da instituição, na natureza de suas atividades, no papel que desempenha na realidade local e no campo científico-universitário, em geral. Tudo isso, no entanto, fortalece, no interior do sistema mantido pelo Executivo Federal, um processo mais concorrencial no qual prevalecem a identificação e a produção de elementos acadêmicos que afirmem ou reconfigurem o perfil de excelência de cada instituição. O jogo concorrencial da diferenciação e da distinção institucional, ou melhor, da ocupação de posições específicas e diferenciadas, contribui para desmontar o sistema federal, tendo em vista que rompe, paulatinamente, com elementos centrais de convergência, que asseguravam, pelo menos em tese, certo nível de solidariedade, como: indissociabilidade ensino-pesquisa-extensão, gestão democrática, padrão unitário de qualidade, carreira unificada e avaliação institucional. 
As universidades federais já começam a exibir diferenças essenciais, especialmente na forma de estruturação e de organização interna, na produção do trabalho acadêmico e na tomada de posição diante das políticas de educação superior e demandas do mercado, se tornando cada vez mais independentes, sobretudo em relação à unidade das Ifes. O processo é potencializado, em parte, porque essas instituições se encontram em diferentes contextos e fases históricas de desenvolvimento acadêmico. Além disso, começam a ganhar importância as posições, as ações e as práticas internas, particularmente por parte de alguns reitores das consideradas grandes universidades federais, em favor de uma disputa mais intensa no interior do sistema federal.

Evidentemente, o processo é condicionado e estimulado, em grande parte, pelas atuais politicas de educação superior, que procuram estabelecer a competição e acentuar os elementos, que marcam a vocação e a distinção institucional, com destaque para as mudanças no padrão de financiamento. Nesse sentido, pode-se levantar duas situações: a) a do crescimento generalizado dos indices de produtividade das Ifes, especialmente a partir de 1997, mormente por meio da expansão de cursos de graduação, que parece indicar uma resposta ajustada à atual política de expansão e massificação da educação superior; b) a do acirramento da disputa em torno dos recursos federais mediante a concorrência estabelecida pela nova matriz de distribuição entre as Ifes, adotada pelo MEC, em 1999, que, ao ampliar os recursos para uma instituição, diminui-os, conseqüentemente, para outra. Ganham importância, também, os pleitos das universidades federais, em torno dos aportes adicionais dos programas especiais, criados, em grande parte, pelo próprio MEC, fazendo com que os convênios se tornem uma fonte fundamental para manutenção ou desenvolvimento dessas instituições.

De um modo geral, portanto, a lógica reformadora das universidades federais joga com a idéia da diferenciação como inerente à natureza das universidades, uma vez que a distinção, o prestígio e a legitimidade científica 
mobilizam e movimentam os agentes acadêmicos do campo científicouniversitário. Assim, além do fato de as políticas em curso estarem baseadas na lógica da diversificação e diferenciação institucional, as universidades federais tendem a se diferenciar, cada vez mais, por duas razões:

a) o ideário e o comprometimento com o projeto de nação, com o desenvolvimento estratégico do país e com a produção de conhecimento e de alta cultura parecem dar lugar, de modo mais intenso, às relações com os contextos local e regional, uma das formas de sobrevivência institucional; a observação dos elementos empíricos dessa mudança, na forma de inserção social das universidades, não indica, no entanto, que já exista um processo de empobrecimento acadêmico dessas instituições;

b) as alterações nos padrões de gestão e de produção acadêmica ocorrem cotidianamente, o que dificulta sua identificação, bem como a tomada de consciência e a definição de uma posição mais radical de resistência; as condições materiais de sobrevivência institucional e dos docentes, embora evidenciem as novas relações de subordinação e de exploração do trabalho acadêmico, implicam uma maior aceitação, indiferença ou facilitação do processo de reorganização do sistema e de ajustamento das universidades federais, sem um projeto orgânico do pool dessas instituições.

Nesse contexto de metamorfose institucional, pode-se considerar a UFG um caso exemplar, uma vez que apresenta modificações cotidianas nos padrões de gestão, financiamento, avaliação, currículo, pesquisa e pósgraduação, que acenam para mudanças estruturais em sua natureza e identidade institucionais, especialmente na produção do trabalho acadêmico. Esses elementos organizativos do trabalho acadêmico mostram-se mais permeáveis às alterações nas relações de produção, o que permite certo ajustamento à lógica de reestruturação da educação superior em curso no país por meio do MEC. 
Essas mudanças alcançam a UFG de forma intensa, em parte, em razão de ser ainda jovem e sua identidade estar em processo de construção. $\mathrm{Na}$ verdade, pode-se dizer que sua configuração histórica e seu perfil no contexto local e no campo científico-universitário encontra-se em fase inicial de construção, tornando-a mais vulnerável às determinações do Executivo Federal, aos sinais do mercado e aos processos de ajustamento em curso, de um modo geral, o que ocorre também, porque se trata de uma universidade que possui status acadêmico moderado no conjunto das federais, em razão do volume de capital intelectual que possui no campo científico-universitário. Ao contrário, se ocupasse posição de maior destaque, em tese, essa instituição poderia resistir ou inovar em nome de uma natureza e de uma identidade mais consolidada.

A análise das alterações na UFG, especialmente daquelas ocorridas nos últimos anos, indica amplo processo de modelação organizacional, centrado em uma lógica, cuja racionalização evidencia a adoção de um paradigma contábil, que objetiva torná-la mais ágil, flexível e eficiente, como evidenciam, por exemplo, a simplificação de sua estrutura acadêmica, a extinção progressiva dos departamentos, a tentativa de desburocratizar os processos administrativos e acadêmicos, por meio da reforma estatutária, e a implantação de sistemas de informação que permitam maior controle e gerenciamento dos recursos. Essas mesmas alterações mostram, ainda, que as mudanças no âmbito da gestão e do financiamento, da avaliação, do currículo e da pesquisa e pós-graduação, em especial a partir do primeiro governo Fernando Henrique Cardoso (1995-1998), ocorrem cotidianamente no processo de tomada de decisão, de atendimento às demandas externas e de busca de melhoria das condições de trabalho, incluindo-se a questão salarial.

Nesse processo de ajustamento, de sobrevivência e de desenvolvimento institucional, há indícios de que a UFG assuma um perfil mais funcional e pragmático, o que pode distanciá-la paulatinamente do ideal de universidade 
como instituição social que se pauta, sobretudo, pela natureza das suas atividades, pela cultura e história institucional e pelo papel que desempenha no processo de emancipação da sociedade. A UFG é atualmente, no quadro das universidades federais, uma instituição marcada pelos seguintes fatores:

a) crescente oferta de cursos de graduação, apesar da diminuição constante no número de professores e servidores técnico-administrativos, que pode melhorar a relação custo-aluno e o acesso aos cursos de graduação, mas também condicionar a identidade e o projeto de universidade possivel, caracterizando-a como uma instituição de ensino voltada para a formação de profissionais;

b) desencadeamento de um processo de flexibilização curricular dos cursos de graduação, objetivando dinamizar a formação acadêmica e ajustá-la às exigências do mercado de trabalho, de acordo com cada área profissional;

c) ampliação constante das atividades de extensão, especialmente na forma da prestação de serviços remunerados;

d) crescimento do atendimento às múltiplas demandas locais e regionais, sobretudo por intermédio de convênios e contratos de prestação de serviços remunerados, que permite ampliar, por um lado, a regionalização e interiorização e, por outro, a receita própria da universidade, que acaba suprindo algumas das lacunas ocasionadas pelas constantes reduções orçamentárias;

e) agilização da prestação de serviços remunerados por meio de fundações de apoio às atividades acadêmicas;

f) ampla oferta de cursos pagos de especialização, que complementam os baixos salários, mas absorvem tempo e energia dos docentes, notadamente daqueles com maior titulação;

g) certa estagnação nos conceitos/notas dos programas de pósgraduação stricto sensu; 
h) implantação de novos cursos de mestrado, mesmo profissionais, em um tempo-espaço em que muitas instituições, mais identificadas pela produção de conhecimento, privilegiam os cursos de doutorado e a pesquisa básica e tecnológica;

i) ausência acentuada de programas de pós-graduação em nível de doutorado e a falta de priorização e de investimento substancial nesse grau de ensino, a despeito de tentativas isoladas de implantação;

j) dificuldade de primar a atuação dos professores doutores na criação e consolidação dos cursos de doutorado e na ampliação quantitativa e qualitativa da pesquisa, em que pese o crescimento acentuado no percentual de mestres e doutores;

1) modernização e modelação organizacional, especialmente por meio do enxugamento da estrutura acadêmica e implantação de sistemas gerenciais (apuração de custos, alocação de vagas, controle acadêmico etc.), que objetivam ampliar a eficiência na gestão e estimular a produtividade;

m) desenvolvimento dos mecanismos de avaliação e controle do trabalho acadêmico, enfatizando a produtividade docente e institucional;

n) participação da comunidade universitária, basicamente por representação nas câmaras e conselhos de decisão da universidade, na formulação das políticas, estratégias e medidas cotidianas de enfrentamento dos problemas atuais.

Esses traços gerais confirmam que as mudanças na organização do tempo-espaço do trabalho acadêmico consubstanciam um processo de metamorfose na identidade institucional da UFG, na perspectiva de torná-la mais operacional. Boa parte do ajustamento dessa universidade, no entanto, faz-se por meio de uma adequação da gestão e da produção do trabalho acadêmico aos parâmetros e aos ritmos da Gratificação de Estímulo à Docência (GED) e aos ditames das condições objetivas locais e regionais, consubstanciados nos convênios e na prestação de serviços remunerados, além do crescimento generalizado nos índices de produtividade por meio, 
especialmente, da expansão dos cursos de graduação. Assim, essa lógica reformadora, pautada na busca constante de eficiência administrativa e de produtividade, está conseguindo alterar a configuração institucional existente e o modus operandi do trabalho acadêmico, ampliando paulatinamente a subordinação da gestão e da produção da universidade aos parâmetros gerais da reforma.

É preciso ressaltar ainda que, no processo de metamorfose da UFG, as tensões, os conflitos e o acirramento das posições em disputa, ocasionados pelas alterações cotidianas nos movimentos e nos processos de organização do tempo-espaço de produção do trabalho acadêmico, diminuem, paulatinamente, sua intensidade ao longo do tempo. À medida que se instalam novas práticas e surgem novas disposições, verifica-se certa adaptação às novas situações. A diminuição na intensidade dos confrontos ocorre, em grande medida, porque há amplo espaço nos conselhos, nas câmaras e na instituição, de um modo geral, para debater as novas temáticas e questões. Assim, a construção colegiada do cotidiano da universidade muda pressupostos antigos, em razão da realidade objetiva da instituição, da qual é possivel extrair, quase sempre, justificativas convincentes para as necessárias alterações nas práticas, nos valores e na cultura institucional, de um modo geral.

Para gerenciar as tensões e os conflitos, a administração superior da UFG utiliza a estratégia de tornar transparentes as dificuldades e as alternativas de solução, conclamando todos a se manifestar com idéias e propostas, embora não se observe participação mais efetiva, sobretudo fora dos colegiados de decisão. Todavia, há grande esforço com o objetivo de catalizar, debater e avaliar os processos ou movimentos de mudança, embora, muitas vezes, não sejam explicitados com muita clareza. Nesse sentido, pode-se enumerar como medidas significativas no momento atual: a) a Ouvidoria Eletrônica, que funciona como um canal aberto com a Reitoria para críticas, denúncias e sugestões; b) a Reitoria Itinerante, que percorre as 
unidades acadêmicas para debater diretamente as questões da universidade; c) o Conselho Político da Reitoria, composto por pessoas indicadas pelas unidades acadêmicas e demais segmentos, com o objetivo de analisar a gestão da universidade e propor grandes linhas de atuação; d) a publicação e a divulgação anual de Relatório de Atividades da Gestão, que faz uma prestação de contas à comunidade universitária; e) as constantes convocações da comunidade acadêmica para realização de Assembléias; f) a nomeação de Comissões de Trabalho que ofereçam subsídios à Reitoria no tocante a temas polêmicos; g) as reuniões com os diferentes segmentos da comunidade universitária e com as entidades sindicais para ouvir e debater problemas e demandas específicas.

Graças a essa participação no processo de tomada de decisão, especialmente nos fóruns colegiados e instâncias superiores da universidade, e, provavelmente, em razão da especificidade de cada uma das áreas que estruturam e organizam o trabalho acadêmico na instituição, verifica-se que os atuais movimentos de metamorfose não caminham em uma única direção, ou seja, eles não são lineares. Esses processos expressam forças de adaptação, de resistência e de inovação presentes na universidade, bem como as lutas naturais do campo em torno da legitimidade científica e, conseqüentemente, em busca da ocupação de posição diferenciada. Internamente, essas forças decorrem, em boa medida, da tomada de posição diante das demandas da sociedade, das políticas de educação superior emanadas do Executivo Federal e das modificações que se processam na instituição.

No processo de tomada de decisão, cada uma das forças presentes demonstra estratégias e formas próprias de consagração de seus pleitos. As forças de adaptação, em parte, vindo de fora da universidade, ou seja, decorrentes das politicas de ajustamento das universidades federais, são mais intensas e mais determinantes no processo de metamorfose da UFG, em virtude do peso que possuem atualmente, como é o caso, por exemplo, da 
GED, do Provão, da nova matriz de financiamento das Ifes e das novas diretrizes curriculares para os cursos de graduação. Em outras palavras, as forças de ajuste são, em grande parte, dominantes sobre as forças de resistência e tolerantes em relação às forças de inovação no interior da instituição. Pode-se afirmar, no entanto, que as forças de resistência, embora minadas e enfraquecidas pela conjuntura, retiram da mesma conjuntura, elementos catalizadores e organizadores da insatisfação com as condições de trabalho presentes na universidade e com o ambiente organizacional em processo de constituição. Porém, essa insatisfação também alimenta as forças de inovação que atuam como bom senso ou senso possivel nesse mar de contradições do processo de metamorfose. É claro que, com freqüência, as forças de inovação, às vezes de improvisação, fazem o jogo das forças de ajuste ou de resistência. Além disso, no caso da UFG, não é possível localizar com clareza os espaços colegiados ou os movimentos organizados que representam essas forças, que, na verdade, estão dispersas e presentes em muitos dos embates institucionais.

O fato é que ainda não se deu inteiramente a metamorfose institucional da UFG, na perspectiva de constituir um perfil mais operacional e contábil. A reforma da educação superior e o processo de ajustamento das universidades federais, de um modo geral, encontram-se em desenvolvimento. Nessa movimentação observam-se sinais de resistência e, por vezes, de inovação, que buscam conservar ou produzir as características da concepção histórica de uma universidade em sentido pleno. A UFG, especificamente, demonstra que não se perdeu no curso dessas transformações, ou seja, parece ter um horizonte mais amplo e tenta formular o seu projeto e o seu desenvolvimento interagindo com as condições objetivas. Procura, assim, formular um novo projeto de universidade, para além do ensino de graduação, de modo a assumir posição de destaque no campo da pós-graduação stricto sensu e da produção de conhecimentos, em que pesem os determinantes externos, a problemática e também as 
limitações internas. A universidade luta, portanto, entre ajustar-se às atuais políticas de educação superior e às demandas do mercado e desenvolver um projeto político-pedagógico próprio, coerente com a construção de sua autonomia, uma vez que parece entender que sua identidade tende a residir na capacidade de diferenciação do sistema.

De um modo geral, no entanto, o processo de regulação do sistema e de ajustamento das universidades federais parece forçar o aparecimento de uma universidade mais dependente das determinações politicas e das metas do Executivo Federal, além de mais mercantilizada na forma de produção acadêmica. Como decorrência, demonstra um modelo de gestão universitária e um modo de produzir o trabalho acadêmico que se distanciam cada vez mais do histórico ideal de liberdade acadêmica e de trabalho intelectual autônomo, o que, no caso da UFG, resulta, por vezes, em uma resposta funcionalista à indução das políticas de educação superior e às demandas contemporâneas. Por vezes, em uma tentativa de desenvolver certa capacidade de lidar com as situações inusitadas, improvisa ou inova, de modo a atualizar-se e a viver em diferentes contextos, sem se subordinar inteiramente ao Estado ou ao mercado.

Esse momento de metamorfose é, portanto, crucial para o conjunto das universidades federais, uma vez que não respeita a história, a identidade e o processo de construção de autonomia em cada instituição. A reorganização da educação superior no Brasil, sobretudo por meio das politicas de diversificação e diferenciação, implica maior ajustamento das universidades, mantidas pelo Poder Público, às demandas e às exigências do mercado, reduzindo progressivamente o exercício da liberdade acadêmica de produção. As políticas de diversificação e diferenciação, cunhadas em uma óptica capitalista estritamente concorrencial, fatalmente, impedirão a formação de uma consciência acadêmica comprometida com os interesses da maioria, além de pôr em risco a finalidade histórica e essencial da universidade: a 
produção do conhecimento autônomo voltado para o bem estar coletivo e para a emancipação social.

Outro risco do processo de metamorfose diz respeito à ordenação e à modelação do tempo-espaço do trabalho e das relações acadêmicas, impregnadas de uma racionalidade mercantil, que impõe uma gestão técnica, racionalizadora e matematizadora da produção acadêmica. Nesse sentido, o comando da gestão universitária e do trabalho acadêmico pode se tornar cada vez mais alheio à especificidade própria desse tipo de trabalho em uma universidade pública federal, cujo financiamento encontra-se ameaçado. Assim, a gestão universitária e o trabalho acadêmico seriam dominados por princípios e por formas de organização pré-postos a eles, o que inviabilizaria o processo de autodeterminação consciente sobre a utilização dos recursos acadêmicos.

Graças à sua especificidade pedagógica e intelectual, a produção do trabalho acadêmico só pode existir como relações sociais entre pessoas, razão pela qual as relações de produção na academia devem ser descobertas, livres, transparentes e autônomas. A condição de sujeito é fundamental para a produção acadêmica, aplicando-se a todos os agentes que compõem a comunidade acadêmica. Por isso, os sujeitos acadêmicos, e não as coisas, devem ser os protagonistas nos intercâmbios e na movimentação das relações de produção na academia. A força de trabalho acadêmica em uma universidade pública deve procurar resguardar-se das determinações da produção capitalista. Nesse sentido, a des-mercantilização da força de trabalho acadêmica (e da educação superior) ${ }^{219}$ torna-se fundamental para anulação das determinações e comandos externos ao campo da produção acadêmica nas universidades federais. É preciso garantir que essas

\footnotetext{
219 Silva Jr. e Sguissardi (1999a) denominam de mercatilização da educação ou, no caso em estudo, de mercantilização da educação superior o novo paradigma educacional, que se orienta predominantemente pela racionalidade do capital e conduz à inequívoca subsunção da esfera educacional à esfera econômica. Nessa perspectiva, ocorre o processo de reordenamento da educação superior no Brasil, que inclui mudanças nas identidades institucionais das universidades.
} 
universidades sejam mantidas com os fundos públicos e que tenham plena autonomia para se autodefinir, sendo reconhecidas, portanto, como um bem público de interesse coletivo. Do mesmo modo, a remuneração da força de trabalho acadêmica precisa ser transparente, conhecida e assumida politicamente como de interesse de toda a sociedade.

Por tudo isso, a luta pela liberdade acadêmica, sem formas tão determinantes de constrangimento, representa um dos modos de enfrentamento desse processo de ajustamento e de metamorfose. A liberdade acadêmica é historicamente constitutiva da universidade, pois lhe permite exercitar o seu papel de crítica, de constituição do novo, de luta pela expansão da esfera pública e pela emancipação social. A liberdade acadêmica, no exercício da produção do conhecimento e do ensino, ou seja, na produção da força de trabalho acadêmica, significa condição essencial para constituição e afirmação da universidade pública.

Outra forma de confronto é entender que grande parte desse processo de metamorfose acontece com a batalha do trabalho e do cotidiano acadêmico e que, portanto, nesse espaço pode-se perder ou vencer parte do jogo em prol da construção de uma universidade pública, democrática, autônoma, gratuita e de qualidade no país, o que implica ter clareza do que está em risco no processo de tomada de decisão, nas ações e nas politicas adotadas pela instituição, bem como incrementar um processo participativo em que a comunidade acadêmica se sinta efetivamente responsável pela construção da universidade.

É evidente que todos esses cuidados não isentam as universidades federais de um amplo controle social, que inclui a avaliação interna e externa, sendo todavia preciso entender que as universidades federais, de responsabilidade do Poder Público federal, devem ser mantidas com recursos dos fundos públicos. Deve-se compreender, ainda, que, como um bem social a serviço da coletividade, essas universidades encontram-se compromissadas com o país, a quem precisam contribuir decisivamente para o seu 
desenvolvimento e para a redução das desigualdades regionais, tornando as realidades nacionais mais homogêneas e equilibradas, o que, no caso das universidades federais, implica assegurar financiamento público, autonomia, avaliação interna e externa, manutenção e desenvolvimento do sistema e gestão democrática. 


\section{REFERÊNCIAS BIBLIOGRÁFICAS}

ACUERDO de Santiago. Dirigentes de Universidades Públicas do Chile. Santiago do Chile, 5 ago. 1999.

AMARAL, Nelson Cardoso. Tópicos especiais em administração universitária: gestão financeira de universidades públicas. Goiânia, s.n.t., 1998.

A autonomia das IFES: desafios e polêmicas. Caminhos. Revista da Associação Profissional dos Docentes da UFMG - Secção Sindical da ANDESSN. Belo Horizonte, n. 18, p. 43-58, dez. 1999.

ANDES Informa. Brasília, v. 11, n. 96, p. 4-5, jan. 2000.

№ 1 DO BRASIL, A. Isto é. São Paulo, 25 jan. 2000.

ARRIGHI, Giovani. O longo século XX: dinheiro, poder e as origens de nosso tempo. 2. ed. Rio de Janeiro: Contraponto; São Paulo: Editora UNESP, 1996.

BALDINO, José Maria. Ensino superior em Goiás em tempos de euforia: da desordem aparente à expansão ocorrida na década de 80. Goiânia, Faculdade de Educação da Universidade Federal de Goiás, 1991. [Dissertação de Mestrado]

BANCO MUNDIAL. La Ensenãnza Superior: las lecciones derivadas de la experiencia. Washington, Banco Mundial, 1995.

BARRETO, Francisco C. de Sá. A necessária expansão do ensino superior brasileiro. Jornal da ANDIFES. Brasília, v. 4, n.15, p.1, out./nov. 1999.

BELLONI, Isaura. GED - análise da distribuição de pontuação e critérios. Brasília, 1999. (mimeo)

BOLHA universitária, A. Folha de S. Paulo. São Paulo, 1 fev. 2000. Editorial.

BOTTOMORE, Tom. Dicionário do pensamento marxista. Rio de Janeiro, Jorge Zahar, 1993.

BOURDIEU, Pierre. A dupla ruptura. In: BOURDIEU, Pierre. Razões práticas: sobre a teoria da ação. Trad. Mariza Corrêa. Campinas, SP: Papirus, 1996.

. O campo científico. In: Ortiz, Renato (org.) Pierre Bourdieu: Sociologia. São Paulo, Ática, 1983, p. 122-155.

Escritos da educação. In: NOGUEIRA, Maria Alice, CATANI, Afrânio Mendes (org). Petrópolis, RJ: Vozes, 1998.

Campo do poder, campo intelectual e habitus de classe. In: BOURDIEU, Pierre. A economia das trocas simbólicas. São Paulo: Editora Perspectiva, 1974.

BRASIL. Congresso Nacional. Lei no 9.394, de 20 de dezembro de 1996. Estabelece as diretrizes e bases da educação nacional. Diário Oficial da União. Brasília, 1996.

Ministério da Educação e do Desporto (MEC). Lei no 9.678, de 3 de julho de 1998. Institui a Gratificação de Estímulo à Docência no Magistério Superior, e dá outras providências. Diário Oficial da União. Brasília, 1998.

. Edital no 4, de 10 dezembro de 1997. Brasília, 1997. 
BRASIL. Ministério da Educação e do Desporto (MEC). Portaria $n^{\circ}$ 80, de 16 de dezembro de 1998. Dispõe sobre o reconhecimento dos mestrados profissionais e dá outras providências. Brasília, 1998a.

. Autonomia universitária: fundamentos para uma lei que regule a autonomia das universidades federais. Brasília: MEC, 1999a.

Censo da educação superior. MEC Notícias. Brasília, 4 jul. $2000 b$. (www.mec.gov.br/acs/jornalis/jul/noticias)

Enfrentar e vencer desafios. MEC: Brasília, abr. 2000a.

Expansão do ensino superior. MEC Notícias. Brasília, 17 dez. 1998b.

(www.mec.gov.br)

Projeto de lei. Dispõe sobre a autonomia das universidades federais e dá outras providências. Brasília: MEC, 1999b.

Uma nova política para o ensino superior brasileiro: subsídios para discussão. Brasília: MEC, 1996.

Fundação Coordenação de Aperfeiçoamento de Pessoal de Nível Superior (Capes). Of. Circular n 28/99/PR/Capes, de 26 de fevereiro de 1999. Brasília: MEC/Capes, 1999.

Ofício Circular no 028/99/PR/Capes. Trata do Programa de Estágio de Docência na Graduação. Brasília: Capes, 26 fev. 1999.

Instituto Nacional de Estudos e Pesquisas Educacionais (Inep). Sinopse estatística do ensino superior graduação - 1996. Brasília: MEC/Inep, 1998.

Brasília: MEC/Inep, 1998.

Sinopse estatística do ensino superior graduação - 1996.

. Sinopse estatística do ensino superior graduação - 1998.

Brasília: MEC/Inep, 1999a.

Plano Nacional de Educação: proposta do Executivo Federal ao Congresso Nacional. Brasília: MEC/Inep, 1998c.

Notícias. Ensino superior mantém tendência de crescimento e diversificação. Brasília: MEC/Inep, 25 jun. 1999b. (www.inep.gov.br)

Secretaria de Ensino Superior (SESu). Avaliação das condições de oferta de cursos de graduação: relatório síntese 1998. Brasília: MEC, 1998.

Comissão Nacional de Acompanhamento e Orientação da GED. Informação 33/99. Brasília, 28 out. 1999.

Presidência da República. Decreto n-2.668, de 13 de julho de 1998. Dispõe sobre critérios para pagamento da Gratificação de Estímulo à Docência no Magistério Superior. Diário Oficial da União. Brasília, 1998.

Decreto no 2.306, de 19 de agosto de 1997. Regulamenta, para o

Sistema Federal de Ensino, as disposições contidas no art. 10 da Medida Provisória no 1.477-39, de 8 de agosto de 1997, e nos arts. 16, 19, 20, 45, 46 e

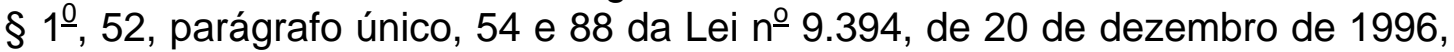
e dá outras providências. Diário Oficial da União. Brasília, 1997.

BRESSER PEREIRA, L.C. Uma reforma gerencial da administração pública no Brasil. In: PETRUCI, V., SCHWARZ, L. Administração pública gerencial: a 
reforma de 1995. Brasília: Editora Universidade de Brasília: ENAP, 1999a, p. 17-62.

BRESSER PEREIRA, L.C., CUNILL GRAU, Nuria. Entre o Estado e o mercado: o público não-estatal. In: BRESSER PEREIRA, L.C., CUNILL GRAU, Nuria (org.). O público não-estatal na reforma do Estado. Rio de Janeiro: Fundação Getúlio Vargas, 1999b, p. 15-48.

CARDOSO, Mirian Limoeiro. A periodização e a ciência da história: observações preliminares. Rio de Janeiro, Jun. 1977. (mimeo)

CARNOY, Martin. A globalização da inovação, competição nacionalista e a internacionalização do treinamento científico. Revista Avaliação. Campinas, SP, v.4, n.1, p.7-18, mar.1999.

CASPER, Gerhard, HUMBOLDT, Wilhelm von. Um mundo sem universidades?. Organização e tradução de Johannes Kretschmer e João C.C. Rocha. Rio de Janeiro: EDUERJ, 1997.

CASTRO, Claudio de Moura, CARNOY, Martin (org.). Como anda a reforma da educação na América Latina. Rio de Janeiro: Ed. Fundação Getúlio Vargas, 1997.

CASTRO, Maria H. Guimarães de. Avaliação do sistema educacional brasileiro: tendências e perspectivas. Brasília, MEC/INEP, 1998.

. Resultados e tendências da educação superior no Brasil. Brasília, MEC/INEP, 27 jun. 2000. (www.inep.gov.br/noticias/news)

CATANI, Afrânio Mendes (org.). Novas perspectivas nas políticas de educação superior na América Latina no limiar do século XXI. Campinas, SP: Autores Associados, 1998.

OLIVEIRA, João Ferreira de. A gratificação de estímulo à docência (GED): alterações no trabalho acadêmico e no padrão de gestão das IFES. In: DOURADO, L.F., CATANI, A. M. (org.). Universidade pública: política e identidade institucional. Campinas, SP: Autores Associados; Goiânia: Ed. da UFG, 1999a, p. 66-74.

- A reestruturação da educação superior no debate internacional: a padronização das políticas de diversificação e diferenciação. Universidade e Sociedade. Brasília, v.10, n. 21, p. 92-101, jan./abr. 2000a.

As políticas de diversificação e diferenciação da educação superior no Brasil: alterações no sistema e nas universidades públicas. São Paulo, 2000b. (mimeo)

A universidade pública no Brasil: identidade e projeto institucional em questão. In: TRINDADE, H. (org.) Universidade em ruínas na república dos professores. Petrópolis, RJ, Vozes/Rio Grande do Sul, CIPEDES, 1999b. p. 179-189.

, DOURADO, L. F. Mudanças no mundo do trabalho e reforma curricular dos cursos de graduação no Brasil. São Paulo, 2000c. (mimeo)

CHAUÍ, Marilena. A universidade em ruínas. In: TRINDADE, H. (org.). Universidade em ruínas na república dos professores. Petrópolis, RJ: Vozes / Rio Grande do Sul: CIPEDES, 1999a. p. 211-222.

. A universidade hoje. Praga - Estudos Marxistas. São Paulo: Ed. HUCITEC, v. 6, p. 23-32, 1998. 
CHAUÍ, Marilena. A universidade operacional. Folha de S. Paulo. São Paulo, 9 jul. 1999b.

. Uma ideologia perversa. Folha de S. Paulo. São Paulo, 14 mar. 1999c.

. Universidade em liquidação. Folha de S. Paulo. São Paulo, 11 jul. 1999d.

. Tiros no pé. Folha de S. Paulo. São Paulo, 31 out. 1999e. Caderno Mais!

. Fantasias da terceira via. Folha de S. Paulo. São Paulo, 19 dez. $1999 f$. Caderno Mais!

CHESNAIS, François. A mundialização do capital. Trad. Silvana Finzi Foá. São Paulo: Xamã, 1996.

CONSELHO NACIONAL DE DESENVOLVIMENTO CIENTÍFICO E TECNOLÓGICO (CNPq). A pesquisa no Brasil. Brasília: CNPq, 1999.

CUNHA, Luís Antônio. Reforma universitária em crise: gestão, estrutura e território. In: TRINDADE, H. (org.). Universidade em Ruínas: na república dos professores.

Petrópolis, RJ: Vozes/Porto Alegre: CIPEDES, 1999, p. 125-148.

Nova reforma do ensino superior: a lógica reconstruída. Cadernos de Pesquisa. Fundação Carlos Chagas (FCC). São Paulo: FCC, n. 101, p.20-49, jul. 1997.

CURY, Carlos R. J. Reforma universitária na nova Lei de Diretrizes e Bases da Educação Nacional. Cadernos de Pesquisa. Fundação Carlos Chagas (FCC). São Paulo: FCC, n. 101, p. 3-19, jul. 1997.

DAGNINO, Renato. A GED e o movimento docente: balanço e perspectivas. Avaliação / Rede de Avaliação Institucional da Educação Superior - RAIES. Brasília, v. 4, n. 3, p. 53-72, set. 1999.

DIÁRIO da Manhã. Goiânia, 25 abr. 1999. Caderno Universidade, p. 5.

DIAS SOBRINHO, José. Evaluacion de la educación superior en Brasil. In: YARZÁBAL, Luis, VILA, Ana, RUÍZ, Roberto (Ed.). Avaluar para transformar. Caracas: IESALC/UNESCO, 1999.

Programa de Avaliação Institucional das Universidades Brasileiras: construção do modelo e implicações. In: CATANI, Afrânio Mendes (org.). Novas perspectivas nas políticas de educação superior na América Latina no limiar do século XXI. Campinas, SP: Autores Associados, 1998, p.137-152.

DIVERSIFICAÇÃO surge como alternativa. MEC. INEP. Notícias. Brasília, 13 maio 1999. (www.inep.gov.br/noticias/news).

DOURADO, Luiz Fernandes. Expansão e interiorização do ensino superior em Goiás nos anos 80: a política de privatização do público. Rio de Janeiro: Universidade Federal do Rio de Janeiro, 1997. (Tese de Doutorado)

., OLIVEIRA, João Ferreira de. Estado, políticas educacionais e reconfiguração da educação superior no Brasil. In: DOURADO, L.F., CATANI, A. M. (org.). Universidade pública: política e identidade institucional. Campinas, SP: Autores Associados; Goiânia: Ed. da UFG, 1999, p. 5-22.

A educação superior em Goiás: regulamentação, políticas e perspectivas na reconstituição do campo universitário. Universidade $e$ Sociedade. Brasília, v.10, n. 21, p. 87-92, jan./abr. 2000.

DREZE, Jacques, DEBELLE, Jean. Concepções de universidade. Trad. Francisco de Assis Garcia e Celina Fontenele Garcia. Fortaleza: Edições UFC, 1983. 
DURHAM, Eunice Ribeiro. A política para o ensino superior brasileiro ante o desafio do novo século. In: CATANI, Afrânio Mendes (org.). Novas perspectivas nas políticas de educação superior na América Latina no limiar do século XXI. Campinas, SP: Autores Associados, 1998a, p. 9-28.

. As universidades públicas e a pesquisa no Brasil. São Paulo: USP/NUPES, 1998b.

Uma política para o ensino superior brasileiro: diagnóstico e proposta. São Paulo: USP/NUPES, 1998c.

ENSINO brasileiro cresce torto. Folha de S. Paulo. São Paulo, 30 jan. 2000. Cotidiano, p. 3.

FANNELI, Ana M. G. de. La universidad pública frente a la nueva lógica de las políticas públicas y del mercado. Revista Avaliação. Campinas, SP, v. 4, n. 1, p. 19-30, mar.1999.

FOLHA de S. Paulo. São Paulo, 17 fev. 2000. Cotidiano, p.5. São Paulo, 7 fev. 2000.

FORGRAD. Documento Conceitual para Sistematização das Diretrizes Curriculares. Brasília, ForGRAD, 1999. (www.prg.ufpb.br/forgrad)

GENTE nova na FUNAP. Diário da Manhã. Goiânia, 6 fev. 2000. Universidade, p. 3

GRAMSCI, Antônio. Cadernos do cárcere, v. 1; edição e tradução, Carlos Nelson Coutinho; co-edição, Luiz Sérgio Henriques e Marco Aurélio Nogueira. Rio de Janeiro: Civilização Brasileira, 1999.

GOIÁS. Secretaria de Planejamento. Goiás no contexto regional e nacional. Goiânia, 1998.

GRUPO KRISIS. Manifesto contra o trabalho. Trad. de Heinz Dieter Heidemann. São Paulo, 1999. (mimeo)

HARVEY, David. Condição pós-moderna. Trad. Adail Ubirajara Sobral e Maria Stela Gonçalves. São Paulo: Edições Loyola, 1992.

JORNAL da Adufg. Goiânia, v. 6, n. 23, 1999. Editorial

LAVILLE, Christian, DIONNE, Jean. A construção do saber. Trad. Heloísa Monteiro e Francisco Settineri. Porto Alegre: Editora Artes Médicas Sul Ltda.; Belo Horizonte: Editora da UFMG, 1999.

LIMA, Eliana Martins. A pós-graduação na UFG. Diário da Manhã. Goiânia, 2 jul. 2000. Caderno Universidade, p. 2.

LIMA, Licínio C. O paradigma da educação contábil: políticas educativas e perspectivas gerencialistas no ensino superior em Portugal In: SGUISSARDI, Valdemar, SILVA Jr., João dos Reis (org.). Políticas públicas para a educação superior. Piracicaba: Ed. UNIMEP, 1997. p. 23-62.

LOJKINE, Jean. A revolução informacional. Trad. José Paulo Netto. São Paulo: Cortez, 1995.

MARTINS, Carlos Benedito. Notas sobre o ensino superior brasileiro contemporâneo. Revista USP. São Paulo, USP, p. 58-82, set./out./nov. 1998.

. O ensino privado no Distrito Federal. Cadernos de Pesquisa. Fundação Carlos Chagas. São Paulo, n. 102, p.157-186, nov. 1997.

MARX, Karl. Contribuição à crítica da economia política. São Paulo: Martins Fontes, 1977. 
MARX, Karl. O Capital: crítica da economia política: livro I. Trad. Reginaldo Sant'Anna. - 15. ed. Rio de Janeiro: Bertrand Brasil, 1996.

O Capital: Livro I, Capítulo VI (inédito). São Paulo: Ciências Humanas, 1978.

MEC lança diretrizes para autonomia universitária e UFRJ anuncia dívida de 22 milhões a fornecedores. Jornal da Ciência. SBPC. Rio de Janeiro, v. 13, n. 411, p. 1, 30 abr. 1999.

MENEGBEL, Stela Maria et alii. Relação universidade $\mathrm{x}$ empresa no Brasil: transformações recentes e implicações para a avaliação institucional. Revista Avaliação. Campinas, SP, v. 4, n. 1, p. 9-21, mar. 1999.

MICELI, Sérgio. A força do sentido. In: Bourdieu, Pierre. A economia das trocas simbólicas. Organização de Sérgio Miceli. São Paulo: Perspectiva, 1974.

MEC quer tornar cursos de graduação mais flexíveis. Folha de S. Paulo. São Paulo, 30 mar. 1998, p. 2.

MOREIRA, Ilka M.A. Autonomia universitária sob o enfoque do financiamento. Goiânia: UFG/PROAD, 1999. (mimeo)

Financiamento e orçamento das IFES: contexto e proposições. Goiânia: UFG/PROAD, 2000. (mimeo)

MOROSINE, Marília, SGUISSARDI, Valdemar (org.). A educação superior em periódicos nacionais. Vitória: FCAA/UFES, 1998.

OFFE, Claus. Capitalismo Desorganizado. Trad. Wanda Caldeira Brant. 2. ed. São Paulo: Editora Brasiliense, 1994.

O IMPASSE da academia. Folha de S. Paulo. São Paulo, 20 jun. 2000. Especial

OLIVEIRA, Francisco de. Os direitos do antivalor: a economia política da hegemonia imperfeita. Petróplis, RJ: Vozes, 1998.

. O surgimento do antivalor: força de trabalho e fundo público. Novos estudos CEBRAP. São Paulo, n. 22, p. 8-28, out. 1988.

OLIVEIRA, João Ferreira. Liberalismo, educação e vestibular: movimentos e tendências para o ingresso no ensino superior no Brasil a partir de 1990. Goiânia: Faculdade de Educação da Universidade Federal de Goiás, 1994. (Dissertação de Mestrado)

A nova reforma da educação superior no Brasil: o processo de desorganização do sistema e de desajustamento da universidade pública. In: SILVA, Rinalva Cassiano (org.). Educação para o século XXI: dilemas e perspectivas. Piracicaba: Editora da UNIMEP, 1999. p.147-160.

LIBÂNEO, José Carlos. A educação escolar e a sociedade contempoânea.

Fragmentos da Cultura. Goiânia, v. 8. n.3. p. 597-612, maio/jun. 1998.

OLIVEIRA, Otom Anselmo. Andifes: mais verbas para universidades. Jornal da Ciência. SBPC. Rio de Janeiro, v. 14 n. 429, p. 2-11, fev. 2000.

POPULAR O. Goiânia, 9 maio 1999.

ORTIZ, Renato. A procura de uma Sociologia da Prática. In: Ortiz, R. (org.). Pierre Bourdieu: Sociologia. São Paulo: Ática, 1983, p. 7-36.

PAIVA, Vanilda, WARDE, Mirian Jorge (org.). Dilemas do ensino superior na América Latina. Campinas, SP: Papirus, 1994.

PARO, Vitor Henrique. Administração Escolar: introdução crítica. 7. ed. São Paulo: Cortez, 1996. 
PARO, Vitor Henrique. A natureza do trabalho pedagógico. Revista da Faculdade de Educação. São Paulo, v. 19, n. 1, p. 103-109, jan./jun. 1993.

PROCURA de alternativas. Diário da Manhã. Goiânia, 11 abr. 1999. Caderno Universidade, p.2.

RIFKIN, Jeremy. O fim dos empregos: o declínio inevitável dos níveis de emprego e a redução da força global de trabalho. São Paulo: Makron, 1995.

RODRIGUES, Zilda de Araújo. Universidade Federal de Goiás: modernização e racionalização da estrutura e da organização do trabalho acadêmico (19841997). Goiânia: UFG, 2000. (Dissertação de Mestrado).

ROUSSEAU, Jean-Jacques. Discurso sobre a origem e os fundamentos da desigualdade entre os homens. Cometários: Jean-François Brausnstein. Brasília: Editora Universidade de Brasília; São Paulo: Ática, 1989.

RUBIN, Isaak Illich. A teoria marxista do valor. Trad. José Bonifácio de S. Amaral Filho. São Paulo: Editora Polis, 1987.

SANTOS, Milton. Ser intelectual na era da globalização. Anais do IX ENDIPE. São Paulo, v. 1/1, 1998, p. 15-20.

Técnica, espaço, tempo: globalização e meio técnico-científico informacional. 3. Ed. São Paulo: Editora Hucitec, 1997.

SGUISSARDI, Valdemar (org.). Avaliação universitária em questão: reformas do Estado e da educação superior. Campinas, SP: Autores Associados, 1997. Autonomia universitária e mudanças no ensino superior: da polissemia do conceito as controvérsias de sua aplicação. In: CATANI, Afrânio Mendes (org.). Novas perspectivas nas políticas de educação superior na América Latina no limiar do século XXI. Campinas, SP: Autores Associados, 1998, p. 29- 48. SILVA JR., João dos Reis (org.). Políticas públicas para a educação superior. Piracicaba: Editora da UNIMEP, 1997.

SILVA JR., João dos Reis, SGUISSARDI, Valdemar. Novas faces da educação superior no Brasil: reforma do Estado e mudança na produção. Bragança Paulista, SP: EDUSF, 1999a.

SGUISSARDI, Valdemar. Reconfiguração da educação superior no Brasil e redefinição das esferas pública e privada nos anos 90. Revista Brasileira de Educação. São Paulo, n. 10, p. 33-57, jan./abr.1999b.

Do Estado do Bem Estar Social ao Estado Gestor. In: CATANI, Afrânio Mendes (org.). Novas perspectivas nas políticas de educação superior na América Latina no limiar do século XXI. Campinas, SP: Autores Associados, 1998, p. 83-101.

SOCIEDADE BRASILEIRA PARA O PROGRESSO DA CIÊNCIA (SBPC). Jornal da Ciência. Rio de Janeiro, 11 fev. 2000. . Jornal da Ciência. Rio de Janeiro, 30 abr. 1999. . Jornal da Ciência. Rio de Janeiro, 11 fev. 2000.

SOUZA, Paulo Renato. A agenda positiva do ensino superior. Estado de S. Paulo. São Paulo, 23 nov. 1998.

Avaliação e expansão do ensino superior. Folha de S. Paulo. São Paulo, 21 dez. 1999.

Melhoria das universidades federais. Folha de S. Paulo. São Paulo, 27 jun. 2000a. 
SOUZA, Paulo Renato. Ensino superior cresce com supervisão e controle. O Estado de S. Paulo. São Paulo, 20 fev. 2000b.

SUCESSO da ciência em Goiás é fruto do esforço pessoal. O Popular. Goiânia, 9 maio 1999.

TEIXEIRA, Anísio. A universidade de ontem e de hoje. Org. e introd. Clarice Nunes. Rio de Janeiro: EdUERJ, 1998a.

Educação e universidade. Org. Maria de L.A. Fávero e Jader de M. Britto. Rio de janeiro: Editora UFRJ, 1998b.

TEIXEIRA, Lúcia Helena G. Cultura organizacional da escola, mudança e formação de profissionais do ensino. In: SILVA, Rinalva C. (org.). Educação para o século XXI: dilema e perspectivas. Piracicaba: Editora UNIMEP, 1999, p. 101-116.

TRIGUEIRO, Michelangelo G. S. Universidades públicas: desafios e possibilidades no Brasil contemporâneo. Brasília: Editora Universidade de Brasília, 1999.

TRINDADE, Hélgio. Editorial. Revista Avaliação. Campinas, v. 4, n. 1, p. 5-6, mar. 1999a.

(org.). Universidade em ruínas na república dos professores. Petrópolis, RJ: Vozes; Rio Grande do Sul: CIPEDES, 1999b.

UNESCO. La educación superior: una puerta abierta al siglo XXI. Dialogo. México, OPI/LAC-UNESCO, n. 25, nov. 1998.

UNIVERSIDADE de São Paulo. Instituto de Estudos Avançados. A presença da universidade pública. São Paulo: USP/IEA, 2000.

UNIVERSIDADE em choque: a dissolução do ensino superior. Folha de S. Paulo. São Paulo, 4 jun. 2000. Mais!

WARDE, Mirian J. Liberalismo e educação. São Paulo: Pontifícia Universidade Católica de São Paulo, 1984. (Tese de Doutorado)

. Síntese: políticas para o ensino superior - os assaltos a uma instituição mal constituída. In: SGUISSARDI, Valdemar, SILVA JR., João dos Reis (org.). Políticas públicas para a educação superior. Piracicaba, SP: Editora da UNIMEP, 1997, p. 279-281.

WEBER, Max. Os fundamentos da organização burocrática: uma construção do tipo ideal. In: Campos, Edmundo (org.). Sociologia da Burocracia. 2. ed. Rio de Janeiro: Zahar Editores, 1971, p. 15-28.

YARZÁBAL, Luís. Situação do ensino superior na América Latina e no Caribe. In: ANDIFES (org.). Mudança e desenvolvimento da universidade pública na América Latina. Brasília: ANDIFES, 1995. p. 51-74. 


\section{UNIVERSIDADE FEDERAL DE GOIÁS (UFG): documentos, resoluções e atas consultadas}

\section{Documentos}

UNIVERSIDADE FEDERAL DE GOIÁS. Jornal da UFG. Goiânia, 6 jan. 1998a. Edição Especial.

Câmara de Graduação. Ao Plenário do Conselho de Ensino, Pesquisa, Extensão e Cultura da UFG. Goiânia: UFG/Câmara de Graduação, 29 mai. 2000.

Comissão Especial do Concurso Vestibular (CECV). Processo seletivo 2000. Goiânia: UFG/CECV, 1999.

. Plano de Gestão 1998-2001. Goiânia, UFG, 1998b.

Pró-Reitoria de Administração e Finanças. Ofício circular $n^{\circ}$ 329/99, de 21 ago. 1999. Goiânia: UFG/PROAD, 1999a.

Pró-Reitoria de Administração e Finanças. Ofício nº 342/99, de 1 set. 1999. Goiânia: UFG/PROAD, 1999b.

Pró-Reitoria de Administração e Finanças. Relatório de prestação de contas da UFG - exercício 1998. Goiânia: UFG/PROAD, 1999c.

Pró-Reitoria de Administração e Finanças. Relatório de prestação de contas da UFG - exercício 1999. UFG/PROAD, 2000.

Pró-Reitoria de Desenvolvimento Institucional e Recursos Humanos. Avaliação institucional na UFG: avaliação interna da graduação. Goiânia: UFG/PRODIRH/Comissão de Avaliação Institucional, 1997.

Pró-Reitoria de Desenvolvimento Institucional e Recursos Humanos. Avaliação institucional da UFG: projeto biênio 96/97. Goiânia: UFG/PRODIRH, 1996.

Pró-Reitoria de Graduação. Ao Plenário do Conselho de Ensino, Pesquisa, Extensão e Cultura da UFG. Goiânia: UFG/PROGRAD, 29 mai. 2000.

- Pró-Reitoria de Graduação. Catálogo de graduação 1997. Goiânia: UFG/PROGRAD, 1997.

Pró-Reitoria de Graduação. Graduação em números. Goiânia: UFG/PROGRAD, 1993.

- Pró-Reitoria de Graduação. O ensino de graduação: contribuições para 0 debate. Goiânia: UFG/PROGRAD, 1996a.

Pró-Reitoria de Graduação. Para entender o regulamento geral de cursos de graduação (RGCG). Goiânia: UFG/PROGRAD, 1999.

- Pró-Reitoria de Graduação. Proposta para o programa de interiorização dos cursos da UFG. Goiânia: UFG/PROGRAD, 1994.

Pró-Reitoria de Graduação. Relatório da comissão criada pela portaria $n^{\circ}$ 3168/96 e ratificada pela portaria $n^{\circ}$ 3396/96, da PROGRAD. Goiânia: UFG/PROGRAD, 20 dez. 1996b.

Pró-Reitoria de Graduação. Regulamento geral dos cursos de graduação. Goiânia: UFG/PROGRAD, 1999b. 
UNIVERSIDADE Federal de Goiás. Pró-Reitoria de Pesquisa e Pós-Graduação. A UFG através da pós-graduação. Goiânia: UFG/PRPPG, 29 jun. 2000. (mimeo) . Pró-Reitoria de Pesquisa e Pós-Graduação. Catálogo dos cursos de pósgraduação. Goiânia: UFG/PRPPG, 1996a.

- Pró-Reitoria de Pesquisa e Pós-Graduação. Normas básicas da pósgraduação. Goiânia, UFG/PRPPG, 1996b.

Pró-Reitoria de Pesquisa e Pós-Graduação. Pesquisa e pós-graduação na UFG. Goiânia: UFG/PRPPG, Editora da UFG, 1996c.

Pró-Reitoria de Pesquisa e Pós-Graduação. Programa de desenvolvimento científico e tecnológico 1998-2001. Goiânia: UFG/PRPPG, 1998.

Reitoria. Carta à Comunidade Universitária. Goiânia: UFG/Reitoria, 1999a.

Reitoria. Carta à Sociedade. Goiânia: UFG/Reitoria, 1998a.

Reitoria. Modelo para a alocação de vagas de docentes. Goiânia:

UFG/Reitoria, 1995a.

- Reitoria. Modelo para a alocação de vagas de servidores técnicoadministrativo. Goiânia: UFG/Reitoria, 1995b.

Reitoria. Plano de gestão 1998-2001. Goiânia: UFG/Reitoria, 1998b.

Reitoria. Prestação de contas à comunidade universitária: relatório de atividades da gestão 1998-2001 relativo ao período 6 jan. 1998 a 6 jan. 1999. Goiânia: UFG/Reitoria, 1999b.

Reitoria. Prestação de contas à comunidade universitária. Relatório de atividades da gestão 1998-2001 relativo ao período 6 jan. 1999 a 6 jan. 2000. Goiânia: UFG/Reitoria, 2000.

Reitoria. Relatório de gestão 1994-1997. Goiânia: UFG/Reitoria, 1998c.

\section{Resoluções}

\subsection{Conselho Universitário (CONSUNI)}

UFG. Resolução $n^{\circ}$ 4/96. Normatiza o registro de freqüência dos servidores técnicoadministrativos da UFG, introduz a ficha de registro de atividades para os docentes e dá outras providências. Goiânia, 1996.

UFG. Resolução $n^{\circ}$ 1/97. Define objetivos e normatiza a extensão na UFG e revoga as Resoluções CCEP/118, de 10/05/77, CCEP/133, de 22/06/79, CCEP/138, de 30/10/79 e CCEP/399, de 07/05/96. Goiânia, 1997.

UFG. Resolução nำ 2/97. Estabelece normas que regulamentam a prestação de serviços remunerados na UFG. Goiânia, 1997.

\subsection{Conselho de Ensino, Pesquisa, Extensão e Cultura (CEPEC)}

UFG. Resolução no 184/83. Fixa princípios e critérios para elaboração dos currículos plenos e dá outras providências. Goiânia, 1983.

UFG. Resolução no 194/84. Dispõe sobre opção pelo regime seriado anual e dá outras providências. Goiânia, 1984. 
UFG. Resolução n² 294/89. Fixa princípios e critérios para elaboração e reformulação dos currículos plenos e dá outras providências, revogando-se a Resolução -

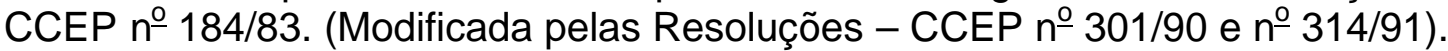
Goiânia, 1989.

UFG. Resolução no 381/95. Dispõe sobre avaliação de desempenho do servidor docente em estágio probatório e revoga as disposições em contrário.

UFG. Resolução $\mathrm{n}^{\circ}$ 411/97. Aprova o regulamento geral dos programas de pósgraduação stricto sensu da UFG.

UFG. Resolução no 417/97. Aprova o regulamento geral dos cursos de pósgraduação lato sensu da UFG.

UFG. Resolução no 446/99. Institui o programa de bolsa de mestrado e de doutorado da UFG e revoga a Resolução - CCEP n $379 / 94$.

UFG. Resolução no 456/99. Disciplina o afastamento de servidores da UFG para realizarem cursos de pós-graduação e programas de pós-doutorado, revogando a Resolução $\mathrm{n}^{0}$ 318/91.

UFG. Resolução $n^{0}$ 462/99. Regulamenta as atividades de pesquisa na UFG, revogando a Resolução - CCEP n 351/92.

UFG. Resolução n 472/99. Regulamenta o estágio de docência na graduação para alunos de pós-graduação stricto sensu da UFG.

UFG. Resolução n $476 / 99$. Institui o programa especial para participação voluntária de docentes aposentados nas atividades de ensino de pós-graduação, pesquisa, extensão e cultura na UFG.

\subsection{Conselho Universitário (CONSUNI) /Conselho de Ensino, Pesquisa, Extensão e Cultura (CEPEC) / Conselho de Curadores}

UFG. Resolução Conjunta CONSUNI/CEPEC/Conselho de Curadores nํㅜ 001/98. Orça a Receita e Fixa a Despesa da UFG, para o exercício financeiro de 1999, de acordo com o Ofício Circular n¹3/98 - MEC/SPO/GAB, de 14/05/98. Goiânia, 1998.

\subsection{Conselho Universitário (CONSUNI) /Conselho de Ensino, Pesquisa, Extensão e Cultura (CEPEC)}

UFG. Resolução Conjunta CONSUNI/CEPEC nํ 001/98. Dispõe sobre a implantação da Gratificação de Estímulo à Docência no âmbito da UFG. Goiânia, 1998.

\subsection{Conselho Diretor (CD) da Faculdade de Educação da UFG}

UFG. Faculdade de Educação. Resolução n 13/98. Goiânia, 1998. 


\section{Atas}

3.1 Atas das Sessões do Conselho Universitário (CONSUNI) da Universidade Federal de Goiás (realizadas em Goiânia)

UFG. Ata da Sessão Conjunta do CONSUNI/CEPEC, 6 nov. 1998.

UFG. Ata da Sessão Plenária do CONSUNI, 29 jan. 1999.

UFG. Ata da Sessão Plenária do CONSUNI, 26 fev. 1999.

UFG. Ata da Sessão Plenária do CONSUNI, 26 mar. 1999.

UFG. Ata da Sessão Plenária do CONSUNI, 23 abr. 1999.

UFG. Ata da Sessão Plenária do CONSUNI, 28 maio 1999.

UFG. Ata da Sessão Plenária do CONSUNI, 25 jun. 1999.

UFG. Ata da Sessão Plenária do CONSUNI, 20 ago. 1999.

UFG. Ata da Sessão Plenária do CONSUNI, 24 set. 1999.

\section{2 Atas das Sessões do Conselho de Ensino, Pesquisa, Extensão e Cultura (CEPEC) da Universidade Federal de Goiás (realizadas em Goiânia)}

UFG. Ata de Sessão Plenária do CEPEC, 22 jan. 1999.

UFG. Ata de Sessão Plenária do CEPEC, 9 fev. 1999.

UFG. Ata de Sessão Plenária do CEPEC, 9 mar. 1999.

UFG. Ata de Sessão Plenária do CEPEC, 16 mar. 1999.

UFG. Ata da Sessão Plenária do CEPEC, 6 abr. 1999.

UFG. Ata da Sessão Extraordinária do CEPEC, 16 abr. 1999.

UFG. Ata da Sessão Plenária do CEPEC, 4 maio 1999.

UFG. Ata da Sessão Plenária do CEPEC, 8 jun. 1999.

UFG. Ata da Sessão Plenária do CEPEC, 21 jun. 1999.

UFG. Ata da Sessão Plenária do CEPEC, 3 ago. 1999.

UFG. Ata da Sessão Plenária do CEPEC, 14 set. 1999.

UFG. Ata da Sessão Plenária do CEPEC, 28 set. 1999.

3.3 Atas das Sessões da Câmara de Graduação do Conselho de Ensino, Pesquisa, Extensão e Cultura (CEPEC) da Universidade Federal de Goiás (realizadas em Goiânia)

UFG. Ata da reunião ordinária da Câmara de Graduação, 20 jan. 1999.

UFG. Ata da reunião ordinária da Câmara de Graduação, 29 mar. 1999.

UFG. Ata da reunião ordinária da Câmara de Graduação, 19 abr. 1999.

UFG. Ata da reunião ordinária da Câmara de Graduação, 3 maio 1999.

UFG. Ata da reunião ordinária da Câmara de Graduação, 17 maio 1999.

UFG. Ata da reunião ordinária da Câmara de Graduação, 31 maio 1999.

UFG. Ata da reunião ordinária da Câmara de Graduação, 21 jun. 1999.

UFG. Ata da reunião ordinária da Câmara de Graduação, 28 jun. 1999.

UFG. Ata da reunião ordinária da Câmara de Graduação, 1 jul. 1999.

UFG. Ata da reunião ordinária da Câmara de Graduação, 7 jul. 1999. 
UFG. Ata da reunião ordinária da Câmara de Graduação, 9 ago. 1999.

UFG. Ata da reunião ordinária da Câmara de Graduação, 16 ago. 1999.

UFG. Ata da reunião ordinária da Câmara de Graduação, 19 ago. 1999.

UFG. Ata da reunião ordinária da Câmara de Graduação, 23 ago. 1999.

UFG. Ata da reunião ordinária da Câmara de Graduação, 30 ago. 1999.

UFG. Ata da reunião ordinária da Câmara de Graduação,13 set. 1999.

UFG. Ata da reunião ordinária da Câmara de Graduação, 20 set. 1999.

UFG. Ata da reunião ordinária da Câmara de Graduação, 27 set. 1999.

UFG. Ata da reunião ordinária da Câmara de Graduação, 18 out. 1999.

UFG. Ata da reunião ordinária da Câmara de Graduação, 08 nov. 1999.

UFG. Ata da reunião ordinária da Câmara de Graduação, 22 nov. 1999.

UFG. Ata da reunião ordinária da Câmara de Graduação, 22 nov. 1999.

3.4 Atas das Sessões da Câmara de Pesquisa e Pós-Graduação (CPPG) do Conselho de Ensino, Pesquisa, Extensão e Cultura (CEPEC) da Universidade Federal de Goiás (realizadas em Goiânia)

UFG. Ata da reunião da Câmara de Pesquisa e Pós-Graduação, 11 fev. 1999.

UFG. Ata da reunião da Câmara de Pesquisa e Pós-Graduação, 25 fev. 1999.

UFG. Ata da reunião da Câmara de Pesquisa e Pós-Graduação, 4 mar. 1999.

UFG. Ata da reunião da Câmara de Pesquisa e Pós-Graduação, 11 mar. 1999.

UFG. Ata da reunião da Câmara de Pesquisa e Pós-Graduação, 25 mar. 1999.

UFG. Ata da reunião da Câmara de Pesquisa e Pós-Graduação, 8 abr. 1999.

UFG. Ata da reunião da Câmara de Pesquisa e Pós-Graduação, 9 set. 1999.

UFG. Ata da reunião da Câmara de Pesquisa e Pós-Graduação, 23 set. 1999. 
ANEXOS 


\section{Anexo 1}

Observação sistemática nos conselhos e câmaras da UFG, no período de fevereiro a dezembro de 1999

\begin{tabular}{|c|c|c|c|c|c|}
\hline Mês & Dia & $\begin{array}{l}\text { Horário } \\
\text { de } \\
\text { Início }\end{array}$ & Conselho/Câmara & $\begin{array}{c}\text { Local } \\
\text { da } \\
\text { Reunião }\end{array}$ & $\begin{array}{c}\text { Duração } \\
\text { da } \\
\text { Reunião }\end{array}$ \\
\hline \multirow[t]{2}{*}{ Fevereiro } & 25 & $8 \mathrm{~h} 30 \mathrm{~min}$. & Câm. de Pesq. e Pós-Grad. & Auditório do FFCH & $4 \mathrm{~h}$ \\
\hline & 26 & $8 \mathrm{~h}$ & CONSUNI & Auditório da FEN & $3 \mathrm{~h}$ \\
\hline \multirow[t]{8}{*}{ Março } & 4 & $8 \mathrm{~h} 30 \mathrm{~min}$. & Câm. de Pesq. e Pós-Grad. & Auditório do FFCH & $3 \mathrm{~h}$ \\
\hline & 9 & $8 \mathrm{~h}$ & CEPEC & Auditório da FEN & $2 \mathrm{~h} 30 \mathrm{~min}$. \\
\hline & 11 & 8h 30min. & Câm. de Pesq. e Pós-Grad. & Auditório do FFCH & $3 \mathrm{~h}$ \\
\hline & 16 & $8 \mathrm{~h}$ & CEPEC & Auditório da FEN & $2 \mathrm{~h} 30 \mathrm{~min}$. \\
\hline & 18 & 14h $30 \mathrm{~min}$. & Câm. de Extensão e Cult. & Auditório da FEN & $2 \mathrm{~h}$ \\
\hline & 24 & 14h 30min. & Conselho de Curadores & Reitoria & $3 \mathrm{~h}$ \\
\hline & 25 & 8h30min. & Câm. de Pesq. e Pós-Grad. & Auditório do FFCH & $3 \mathrm{~h}$ \\
\hline & 26 & $8 \mathrm{~h}$ & CONSUNI & Auditório da FEN & $2 \mathrm{~h}$ \\
\hline \multirow[t]{2}{*}{ Abril } & 6 & $8 \mathrm{~h}$ & CEPEC & Auditório da FEN & $2 \mathrm{~h}$ \\
\hline & 26 & $14 \mathrm{~h}$ & Câmara de Graduação & Auditório do IF & $3 \mathrm{~h}$ \\
\hline \multirow[t]{6}{*}{ Maio } & 3 & $14 \mathrm{~h}$ & Câmara de Graduação & Auditório do IF & $3 \mathrm{~h}$ \\
\hline & 4 & $8 \mathrm{~h}$ & CEPEC & Auditório da FEN & $2 \mathrm{~h}$ \\
\hline & 10 & $14 \mathrm{~h}$ & Câmara de Graduação & Auditório do IF & $3 \mathrm{~h}$ \\
\hline & 17 & $14 \mathrm{~h}$ & Câmara de Graduação & Auditório do IF & $3 \mathrm{~h}$ \\
\hline & 27 & $8 \mathrm{~h} 30 \mathrm{~min}$. & Câm. de Pesq. e Pós-Grad. & Auditório do IF & $3 \mathrm{~h}$ \\
\hline & 28 & $8 \mathrm{~h}$ & CONSUNI & Auditório da FEN & $3 \mathrm{~h}$ \\
\hline \multirow[t]{7}{*}{ Junho } & 7 & $14 \mathrm{~h}$ & Câmara de Graduação & Auditório do IF & $3 \mathrm{~h}$ \\
\hline & 8 & $8 \mathrm{~h}$ & CEPEC & Auditório da FEN & $2 \mathrm{~h} 30 \mathrm{~min}$. \\
\hline & 10 & $8 \mathrm{~h} 30 \mathrm{~min}$. & Câm. de Pesq. e Pós-Grad. & Auditório do IF & $3 \mathrm{~h}$ \\
\hline & 14 & $14 \mathrm{~h}$ & Câmara de Graduação & Auditório do IF & $3 \mathrm{~h}$ \\
\hline & 24 & $8 \mathrm{~h} 30 \mathrm{~min}$. & Câm. de Pesq. e Pós-Grad. & Auditório do IF & $3 \mathrm{~h}$ \\
\hline & 25 & $8 \mathrm{~h}$ & CONSUNI & Auditório da FEN & $2 \mathrm{~h} 30 \mathrm{~min}$. \\
\hline & 28 & $14 \mathrm{~h}$ & Câmara de Graduação & Auditório da IF & $3 \mathrm{~h}$ \\
\hline \multirow[t]{2}{*}{ Julho } & 1 & $14 \mathrm{~h}$ & Câmara de Graduação & Auditório do IF & $3 \mathrm{~h}$ \\
\hline & 6 & $8 \mathrm{~h}$ & CEPEC & Auditório da FEN & $3 \mathrm{~h}$ \\
\hline \multirow[t]{7}{*}{ Agosto } & 3 & $8 \mathrm{~h}$ & CEPEC & Auditório da FEM & $3 \mathrm{~h}$ \\
\hline & 9 & $14 \mathrm{~h}$ & Câmara de Graduação & Auditório do IF & $3 \mathrm{~h}$ \\
\hline & 12 & $8 \mathrm{~h} 30 \mathrm{~min}$. & Câm.Pesq. e Pós-Grad. & Auditório do IF & $3 \mathrm{~h}$ \\
\hline & 19 & $14 \mathrm{~h}$ & Câmara de Graduação & Auditório da FEN & $3 \mathrm{~h}$ \\
\hline & 20 & $8 \mathrm{~h}$ & CONSUNI & Auditório da FEN & $3 \mathrm{~h}$ \\
\hline & 23 & $14 \mathrm{~h}$ & Câmara de Graduação & Auditório do IF & $3 \mathrm{~h}$ \\
\hline & 30 & $14 \mathrm{~h}$ & Câmara de Graduação & Auditório do IF & $3 \mathrm{~h}$ \\
\hline
\end{tabular}




\begin{tabular}{|c|c|c|c|c|c|}
\hline \multirow[t]{5}{*}{ Setembro } & 13 & $14 \mathrm{~h}$ & Câmara de Graduação & Auditório do IF & $3 \mathrm{~h}$ \\
\hline & 14 & $8 \mathrm{~h}$ & CEPEC & Auditório da FEN & $3 \mathrm{~h}$ \\
\hline & 20 & $14 \mathrm{~h}$ & Câmara de Graduação & Auditório do IF & $3 \mathrm{~h}$ \\
\hline & 21 & $8 \mathrm{~h}$ & CEPEC & Auditório da FEN & $3 \mathrm{~h}$ \\
\hline & 24 & $8 \mathrm{~h}$ & CONSUNI & Auditório da FEN & $3 \mathrm{~h}$ \\
\hline \multirow[t]{3}{*}{ Outubro } & 4 & $14 \mathrm{~h}$ & Câmara de Graduação & Auditório do IF & $3 \mathrm{~h}$ \\
\hline & 5 & $8 \mathrm{~h}$ & CEPEC & Auditório da FEN & $3 \mathrm{~h}$ \\
\hline & 7 & $8 \mathrm{~h} 30 \mathrm{~min}$. & Câm. Pesq. e Pós-Grad. & Auditório do IF & $3 \mathrm{~h}$ \\
\hline \multirow{3}{*}{ Novembro } & 8 & $14 \mathrm{~h}$ & Câmara de Graduação & Auditório do IF & $3 \mathrm{~h}$ \\
\hline & 9 & $8 \mathrm{~h}$ & CEPEC & Auditório da FEN & $3 \mathrm{~h}$ \\
\hline & 18 & $8 \mathrm{~h} 30 \mathrm{~min}$. & Câm. Pesq. e Pós-Grad. & Sala BC & $3 \mathrm{~h}$ \\
\hline \multirow[t]{5}{*}{ Dezembro } & 2 & $8 \mathrm{~h} 30 \mathrm{~min}$. & Câm. Pesq. e Pós-Grad. & Sala BC & $3 \mathrm{~h}$ \\
\hline & 7 & $8 \mathrm{~h}$ & CEPEC & Auditório da FEN & $3 \mathrm{~h}$ \\
\hline & 10 & $8 \mathrm{~h}$ & CEPEC & Auditório da FEN & $3 \mathrm{~h}$ \\
\hline & 21 & $8 \mathrm{~h}$ & CONSUNI & Auditório da FEN & $3 \mathrm{~h}$ \\
\hline & & & & C/H Total & $142 \mathrm{~h}$ \\
\hline
\end{tabular}




\section{Anexo 2}

Número de unidades acadêmicas da UFG, por áreas de conhecimento e campi em Goiânia

\begin{tabular}{|c|c|c|}
\hline Áreas de Conhecimento & Unidades Acadêmica & Campi em Goiânia \\
\hline Ciências Humanas & 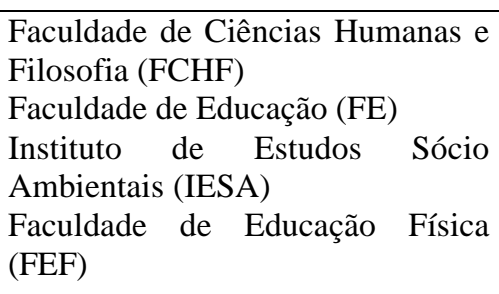 & $\begin{array}{l}\text { Campus II } \\
\text { Campus I } \\
\text { Campus II } \\
\text { Campus II }\end{array}$ \\
\hline Ciências Sociais Aplicadas & $\begin{array}{l}\text { Faculdade de Direito (FD) } \\
\text { Faculdade de Comunicação e } \\
\text { Biblioteconomia (FACOMB) }\end{array}$ & $\begin{array}{l}\text { Campus I } \\
\text { Campus II }\end{array}$ \\
\hline Ciências da Saúde & $\begin{array}{l}\text { Faculdade de Enfermagem (FEN) } \\
\text { Faculdade de Nutrição (FANUT) } \\
\text { Faculdade de Farmácia (FF) } \\
\text { Faculdade de Odontologia (FO) } \\
\text { Faculdade de Medicina (FM) }\end{array}$ & $\begin{array}{l}\text { Campus I } \\
\text { Campus I } \\
\text { Campus I } \\
\text { Campus I } \\
\text { Campus I }\end{array}$ \\
\hline Ciências Agrárias & $\begin{array}{l}\text { Escola de Agronomia (EA) } \\
\text { Escola de Veterinária (EV) }\end{array}$ & $\begin{array}{l}\text { Campus II } \\
\text { Campus II }\end{array}$ \\
\hline Ciências Exatas & $\begin{array}{l}\text { Instituto de Matemática } \\
\text { Estatística (IME) } \\
\text { Instituto de Física (IF) } \\
\text { Instituto de Informática (INF) } \\
\text { Instituto de Química (IQ) }\end{array}$ & $\begin{array}{l}\text { Campus II } \\
\text { Campus II } \\
\text { Campus II } \\
\text { Campus II }\end{array}$ \\
\hline Engenharias & $\begin{array}{l}\text { Escola de Engenharia Civil (EEC) } \\
\text { Escola de Engenharia Elétrica } \\
\text { (EEE) }\end{array}$ & $\begin{array}{l}\text { Campus I } \\
\text { Campus I }\end{array}$ \\
\hline Lingüística, Letras e Artes & $\begin{array}{l}\text { Faculdade de Letras (FL) } \\
\text { Faculdade de Artes Visuais } \\
\text { (FAV) } \\
\text { Escola de Música - EM }\end{array}$ & $\begin{array}{l}\text { Campus II } \\
\text { Campus II } \\
\text { Campus II }\end{array}$ \\
\hline Ciências Biológicas & $\begin{array}{l}\text { Instituto de Ciências Biológicas } \\
\text { (ICB) } \\
\text { Instituto de Patologia Tropical } \\
\text { e Saúde Pública (IPTSP) }\end{array}$ & $\begin{array}{l}\text { Campus II } \\
\text { Campus I }\end{array}$ \\
\hline
\end{tabular}




\section{Anexo 3}

Reitores da UFG, conforme período de gestão

\begin{tabular}{|c|c|}
\hline Período & Nome do Reitor(a) \\
\hline 1961-1964 & Colemar Natal e Silva \\
\hline 1964 & José Martins D’Alvarez \\
\hline 1964-1969 & Jerônimo Geraldo de Queiroz \\
\hline $1969-1973$ & Farnese Dias Maciel Neto \\
\hline 1973-1977 & Paulo de Bastos Perilo \\
\hline $1977-1981$ & José Cruciano de Araújo \\
\hline 1982-1986 & Maria do Rosário Cassimiro \\
\hline 1986-1990 & Joel Pimentel de Ulhôa \\
\hline 1990-1994 & Ricardo Freua Bufaiçal \\
\hline 1994-1998 & Ary Monteiro do Espírito Santo \\
\hline 1998- & Milca Severino Pereira ${ }^{220}$ \\
\hline
\end{tabular}

220 A gestão de Milca Severino Pereira refere-se ao período 1998-2001. 


\section{Anexo 4}

Número de vagas ofertadas nos cursos de graduação da UFG/2000, por cursos e cidades

\begin{tabular}{|c|c|c|}
\hline Cursos & Cidades & Vagas \\
\hline 1. Ciência da Computação & Goiânia & 30 \\
\hline 2. Ciência da Computação & Catalão & 20 \\
\hline 3. Engenharia Civil & Goiânia & 84 \\
\hline 4. Engenharia Elétrica & Goiânia & 72 \\
\hline $\begin{array}{l}\text { 5. Engenharia da Computação - } \\
\text { noturno }\end{array}$ & Goiânia & 36 \\
\hline 6. Física (bac. e lic.) & Goiânia & 60 \\
\hline 7. Matemática (bac. lic.) & Goiânia & 60 \\
\hline 8. Matemática (lic.) - noturno & Goiânia & 40 \\
\hline 9. Matemática (lic.) - noturno & Jataí & 40 \\
\hline 10. Matemática (lic.) - noturno & Catalão & 45 \\
\hline 11. Matemática (lic.) & Rialma & 30 \\
\hline 12. Química (bac. e lic.) & Goiânia & 60 \\
\hline 13. Agronomia & Goiânia & 102 \\
\hline 14. Agronomia & Jataí & 30 \\
\hline $\begin{array}{l}\text { 15. Ciências Biológicas (bac. em } \\
\text { Biomedicina) }\end{array}$ & Goiânia & 15 \\
\hline $\begin{array}{l}\text { 16. Ciências Biológicas (bac. em } \\
\text { Biologia) }\end{array}$ & Goiânia & 15 \\
\hline 17. Ciências Biológicas (lic.) - not. & Goiânia & 30 \\
\hline 18. Ciências Biológicas (lic.) - mat. & Goiânia & 15 \\
\hline 19. Ciências Biológicas (lic.) & Jataí & 30 \\
\hline 20. Enfermagem - integral & Goiânia & 50 \\
\hline 21. Eng. Alimentos - integral & Goiânia & 40 \\
\hline 22. Farmácia & Goiânia & 70 \\
\hline 23. Medicina & Goiânia & 110 \\
\hline 24. Medicina Veterinária & Goiânia & 100 \\
\hline 25. Medicina Veterinária & Jataí & 30 \\
\hline 26. Nutrição & Goiânia & 40 \\
\hline 27. Odontologia & Goiânia & 60 \\
\hline 28. Biblioteconomia & Goiânia & 25 \\
\hline 29. Ciências Sociais (bac. e lic.) & Goiânia & 60 \\
\hline 30. Com. Social (hab. Jornalismo) & Goiânia & 40 \\
\hline $\begin{array}{l}\text { 31. Com. Social (hab. Publicidade e } \\
\text { Propaganda) }\end{array}$ & Goiânia & 25 \\
\hline $\begin{array}{l}\text { 32. Com. Social (hab. Radialismo - } \\
\text { Rádio e Televisão) }\end{array}$ & Goiânia & 30 \\
\hline $\begin{array}{l}\text { 33. Com. Social (hab. Relações } \\
\text { Públicas) }\end{array}$ & Goiânia & 30 \\
\hline 34. Direito - matutino & Goiânia & 60 \\
\hline 35. Direito - noturno & Goiânia & 60 \\
\hline 36. Direito - noturno & Goiás & 60 \\
\hline 37. Filosofia (bac. e lic.) & Goiânia & 46 \\
\hline 38. Geografia (bac. e lic.) & Goiânia & 40 \\
\hline
\end{tabular}




\begin{tabular}{|l|l|l|}
\hline 39. Geografia (lic.) - noturno & Goiânia & 40 \\
40. Geografia (lic.) & Jataí & 40 \\
41. Geografia (bac. e lic.) & Catalão & 45 \\
42. História (bac. e lic.) & Goiânia & 60 \\
43. História (bac. e lic.) - noturno & Goiânia & 60 \\
44. História (bac. e lic.) & Catalão & 40 \\
45. Letras (bac. e lic.) - matutino & Goiânia & 90 \\
46. Letras (lic. em Português) - & Goiânia & 70 \\
vespertino & & \\
47. Letras (lic. em Português) - & Jataí & 40 \\
noturno & & \\
48. Letras (lic. em Inglês) - noturno & Jataí & 30 \\
49. Letras (lic. em Port.) - mat. & & \\
50. Letras (lic. Port.) - noturno & Catalão & 25 \\
51. Pedagogia (lic.) - matutino & Catalão & 40 \\
52. Pedagogia (lic.) - noturno & Goiânia & 70 \\
53. Pedagogia (lic.) - noturno & Goiânia & 70 \\
54. Pedagogia (lic.) & Jataí & 70 \\
55. Educação Física (lic.) - mat. & Catalão & 45 \\
56. Educação Física (lic.) - vesp. & Goiânia & 40 \\
57. Educação Física (lic.) & Goiânia & 40 \\
58. Educação Física (lic.) & Jataí & 40 \\
59. Artes Cênicas (bac.) - noturno & Catalão & 40 \\
60. Artes Visuais - matutino & Goiânia & 25 \\
61. Artes Visuais - vespertino & Goiânia & 45 \\
62. Artes Visuais - mat. & Goiânia & 35 \\
63. Design de Moda & Goiânia & 25 \\
64. Música - matutino & Goiânia & 25 \\
65. Musicoterapia (bac.) & Goiânia & 60 \\
& & \\
\hline & & $\mathbf{3 . 0 2 0}$ \\
\hline
\end{tabular}

Fonte: UFG/CECV. Processo seletivo misto 2000. Manual do Candidato. Goiânia, 1999. 


\section{Anexo 5}

Medidas e ações significativas na $\mathrm{UFG}^{221}$ : 1989-1999

\begin{tabular}{|c|c|c|}
\hline $\begin{array}{c}\text { Medidas/Ações institucionais } \\
\text { significativas }\end{array}$ & Finalidades básicas & Anos \\
\hline $\begin{array}{l}\text { Reforma Curricular (Resolução } \\
\text { CCEP n }{ }^{0} \text { 294/89) }\end{array}$ & $\begin{array}{l}\text { Fixar princípios e critérios para elaboração e } \\
\text { reformulação dos currículos plenos e dá outras } \\
\text { providências, revogando a Resolução CCEP } n^{0} \\
184 / 83^{222}\end{array}$ & 1989 \\
\hline $\begin{array}{l}\text { Sistema de Informações da UFG } \\
\left.\text { (SIUFG) (Resolução } n^{-0} 1 / 89\right)\end{array}$ & $\begin{array}{l}\text { Disciplinar a geração, o tratamento e a difusão de } \\
\text { informações, objetivando prover subsídios para o } \\
\text { processo contínuo de avaliação e tomadas de } \\
\text { decisão. Contém o Sub-sistema de Apuração de } \\
\text { Custos (SAC), Sistema de Atividades Docentes } \\
\text { (SAD) e Sistema de Controle Acadêmico (SCA) }\end{array}$ & 1989 \\
\hline $\begin{array}{l}\text { Subsistema de Apuração de Custos } \\
\text { (SAC) (Resolução ECUn }{ }^{0} \text { 3/89) }\end{array}$ & $\begin{array}{l}\text { Integrar o Sistema de Informações da UFG e } \\
\text { permitir o conhecimento do custo de cada produto } \\
\text { ou serviço gerado na instituição }\end{array}$ & 1989 \\
\hline $\begin{array}{l}\text { Sistema de Controle Acadêmico } \\
\text { (SCA) (Resolução ECU n }{ }^{-0} 4 / 89 \text { ) }\end{array}$ & $\begin{array}{l}\text { Coletar, registrar, tratar e manter dados relativos à } \\
\text { vida acadêmica dos alunos de graduação, bem como } \\
\text { gerar estatísticas e indicadores acadêmicos } \\
\text { relevantes }\end{array}$ & 1989 \\
\hline Fórum de Licenciatura & $\begin{array}{l}\text { Avaliar e Implantar política de formação de } \\
\text { professores na UFG }\end{array}$ & 1989 \\
\hline $\begin{array}{l}\text { Modelo de Alocação de Recursos } \\
\text { Financeiros/Modelo para } \\
\text { Distribuição de Recursos de } \\
\text { Custeio e Capital }\end{array}$ & $\begin{array}{l}\text { Melhorar o gerenciamento dos recursos financeiros } \\
\text { da instituição }\end{array}$ & 1989 \\
\hline $\begin{array}{l}\text { Sistema de Atividades Docentes } \\
\text { (SAD) }\end{array}$ & $\begin{array}{l}\text { Permitir que o discente avalie o docente, } \\
\text { objetivando progressão horizontal }\end{array}$ & 1989 \\
\hline $\begin{array}{l}\text { Relatório Anual de Atividade } \\
\text { Docente (RADOC) } \\
\text { Órgão responsável: Comissão }\end{array}$ & $\begin{array}{l}\text { Registrar todas as atividades docentes realizadas } \\
\text { com sua respectiva carga horária (ensino, pesquisa, } \\
\text { extensão, qualificação, administração, produtos e }\end{array}$ & 1989 \\
\hline
\end{tabular}

221 Consideraram-se, especialmente, as medidas e ações ligadas às seguintes áreas: gestão, avaliação, financiamento, currículo e pesquisa. Muitas outras medidas e ações não foram aqui listadas, embora sejam importantes no contexto de mudança na instituição.

222 A Resolução no $184 / 83$, do Conselho Coordenador de Ensino e Pesquisa(CCEP), tratava da Reforma Curricular, ocorrida em 1983. Essa Resolução instituiu o regime seriado na UFG. 


\begin{tabular}{|c|c|c|}
\hline $\begin{array}{l}\text { Permanente do Pessoal Docente } \\
\text { (CPPD) }\end{array}$ & outras atividades especiais) & \\
\hline $\begin{array}{l}\text { Sistema de Análise de } \\
\text { Desempenho dos servidores } \\
\text { técnico-administrativos } \\
\text { (Resolução ECU } \mathrm{n}^{0} 7 / 92 \text { ) }\end{array}$ & $\begin{array}{l}\text { Estabelecer critérios para análise de desempenho da } \\
\text { atividade técnica e administrativa a ser aplicada aos } \\
\text { servidores e docentes que atuam em atividades } \\
\text { nessas áreas }\end{array}$ & 1992 \\
\hline $\begin{array}{l}\text { Aprovação do Regimento Interno } \\
\text { do Centro de Estudos Regionais } \\
\text { (CER), instituído pela Res. } n^{0} 5 / 87\end{array}$ & $\begin{array}{l}\text { Estabelecer a reflexão, investigação e produção de } \\
\text { estudos aplicados à realidade da Região Centro- } \\
\text { Oeste }\end{array}$ & 1993 \\
\hline $\begin{array}{l}\text { Modelo para Alocação de Vagas } \\
\text { de Docentes (Resolução } \\
\text { ECU/CCEP n }{ }^{0} 1 / 93 \text {, revogada pela } \\
\text { Resolução ECU/CCEP n }{ }^{0} 1 / 95\end{array}$ & $\begin{array}{l}\text { Estabelece as variáveis qualitativas e quantitativas e } \\
\text { os critérios (com a devida ponderação das } \\
\text { atividades) para alocação de vagas de docentes }\end{array}$ & $\begin{array}{c}1993 \\
\mathrm{e} \\
1995\end{array}$ \\
\hline $\begin{array}{l}\text { Avaliação Institucional (PAIUB)/ } \\
\text { Avaliação Interna e Externa da } \\
\text { Graduação na UFG }\end{array}$ & $\begin{array}{l}\text { Implantar o processo de avaliação institucional na } \\
\text { UFG, com a adesão ao PAIUB/SESu/MEC }\end{array}$ & $\begin{array}{c}1994 \\
\mathrm{e} \\
1995\end{array}$ \\
\hline $\begin{array}{l}\text { Reformulação do Estatuto e do } \\
\text { Regimento da UFG }\end{array}$ & Alterar estatuto e regimento anteriores & $\begin{array}{l}1994 \\
\text { e } \\
1995\end{array}$ \\
\hline $\begin{array}{l}\text { Sistema de Acompanhamento e } \\
\text { Avaliação do Programa de } \\
\text { Iniciação Científica }\end{array}$ & $\begin{array}{l}\text { Acompanhar e avaliar o Programa de Iniciação } \\
\text { Científica da UFG (Bolsistas) }\end{array}$ & \\
\hline $\begin{array}{l}\text { Proposta para o Programa de } \\
\text { Interiorização dos Cursos da UFG }\end{array}$ & $\begin{array}{l}\text { Estabelecer proposta de interiorização de Cursos e } \\
\text { Programas da UFG }\end{array}$ & 1994 \\
\hline $\begin{array}{l}\text { Constituição da Comissão de } \\
\text { Avaliação Institucional (CAVI) }\end{array}$ & $\begin{array}{l}\text { Desenvolver o Projeto de Avaliação Institucional da } \\
\text { UFG/PAIUB }\end{array}$ & 1994 \\
\hline $\begin{array}{l}\text { Modelo para a Alocação de Vagas } \\
\text { de Servidores Técnico- } \\
\text { Administrativos (Resolução ECU } \\
n^{0} 7 / 95 \text { ) }\end{array}$ & $\begin{array}{l}\text { Estabelecer as variáveis qualitativas e quantitativas } \\
\text { e os critérios (com a devida ponderação das } \\
\text { atividades) para alocação de vagas de servidores } \\
\text { técnico-administrativos }\end{array}$ & 1995 \\
\hline $\begin{array}{l}\text { Programa Regional Integrado de } \\
\text { Pesquisa e Extensão da UFG } \\
\text { (PRIPE)/Projeto de Domesticação } \\
\text { de Plantas do Cerrado e sua } \\
\text { Incorporação } \quad \text { a Sistemas } \\
\text { Produtivos Regionais }\end{array}$ & $\begin{array}{l}\text { Criar e implementar Programa Regional Integrado } \\
\text { de pesquisa e extensão (PRIPE), com enfoque em } \\
\text { Biotecnologia e Meio Ambiente, especialmente do } \\
\text { cerrado do Estado de Goiás. }\end{array}$ & 1995 \\
\hline $\begin{array}{l}\text { Resolução } \mathrm{n}^{0} \quad 1 / 97 \quad-\text { Define } \\
\text { objetivos e } \\
\text { na UFG }\end{array}$ & $\begin{array}{l}\text { Conceituar, definir os objetivos e normatizar a área } \\
\text { de extensão na UFG }\end{array}$ & 1997 \\
\hline
\end{tabular}




\begin{tabular}{|c|c|c|}
\hline Rede Multitec & $\begin{array}{l}\text { Estimular o desenvolvimento e a utilização de } \\
\text { Novas Tecnologias na Educação, bem como } \\
\text { desenvolver a cultura de Educação a Distância }\end{array}$ & 1996 \\
\hline $\begin{array}{llr}\text { Registro da } & \text { Freqüência dos } \\
\text { Servidores } & \text { Técnico } \\
\text { Administrativos e } & \text { Registro das } \\
\text { Atividades dos } & \text { Docentes } \\
\text { (Resolução ECU n } & \text { 4/96) }\end{array}$ & $\begin{array}{l}\text { Registrar diária e mensalmente a frequêencia dos } \\
\text { servidores e as atividades de cada docente em ficha } \\
\text { de Registro de Atividades (FRA) }\end{array}$ & 1996 \\
\hline $\begin{array}{l}\text { Criação, na Reforma Estatutária e } \\
\text { Regimental, dos Núcleos de } \\
\text { Estudos e Pesquisas (NEPES) }\end{array}$ & $\begin{array}{l}\text { Promover o desenvolvimento da pesquisa e dos } \\
\text { estudos interdisciplinares }\end{array}$ & 1996 \\
\hline $\begin{array}{l}\text { Sistema de Avaliação Institucional } \\
\text { (SAI) }\end{array}$ & $\begin{array}{l}\text { Construir um sistema de Avaliação Institucional } \\
\text { com base nos dados da avaliação institucional } \\
\text { (UFG/PAIUB) }\end{array}$ & 1996 \\
\hline $\begin{array}{l}\text { Avaliação Institucional (PAIUB) - } \\
\text { Projeto para o Biênio 96/97 } \\
\text { Obs: Não foi realizado }\end{array}$ & $\begin{array}{l}\text { Ampliar o processo de Avaliação Institucional na } \\
\text { UFG, incluindo as atividades de pesquisa e de pós- } \\
\text { graduação, de extensão e de administração }\end{array}$ & $\begin{array}{l}1996 \\
1997\end{array}$ \\
\hline $\begin{array}{l}\text { Avaliação da Resolução CCEP } n^{0} \\
\text { 294/89 (Reforma Curricular - } \\
\text { 1989) }\end{array}$ & $\begin{array}{l}\text { Constitui Comissão de Especialistas no processo de } \\
\text { Avaliação Institucional UFG/PAIUB para avaliar a } \\
\text { reforma curricular de } 1989\end{array}$ & 1996 \\
\hline $\begin{array}{l}\text { Exame Nacional de Cursos (ENC); } \\
\text { Avaliação das Condições de Oferta } \\
\text { de Cursos de Graduação - } \\
\text { MEC/INEP }\end{array}$ & $\begin{array}{l}\text { Avaliar os Cursos de Graduação por meio: } \\
\text { a) Exame Nacional de Cursos; } \\
\text { b) Avaliação de Cursos de Graduação pelas } \\
\text { Comissões de Ensino da SESu/MEC }\end{array}$ & $\begin{array}{l}\text { Início } \\
\text { em } \\
1996\end{array}$ \\
\hline $\begin{array}{l}\text { Fundação Rádio e Televisão } \\
\text { Educativa e Cultural (RTVE) }\end{array}$ & Implantar a TV Universitária e a Rádio FM & 1997 \\
\hline $\begin{array}{l}\text { Normatização da Prestação de } \\
\text { Serviços (Resolução } n^{0} 2 / 97\end{array}$ & $\begin{array}{l}\text { Estabelecer normas para a prestação de serviços } \\
\text { remunerados na UFG }\end{array}$ & 1997 \\
\hline $\begin{array}{l}\text { Comissão, constituída pela Pró- } \\
\text { Reitoria de Graduação, para } \\
\text { Reforma da Organização do } \\
\text { Sistema Acadêmico (Reforma } \\
\text { Curricular) }\end{array}$ & $\begin{array}{l}\text { Estabelecer regras para a organização do Sistema } \\
\text { Acadêmico da UFG (Reforma Curricular) }\end{array}$ & 1998 \\
\hline $\begin{array}{l}\text { Fundação Hospital das Clínicas } \\
\text { (FUNDACH) }\end{array}$ & Apoiar as atividades do Hospital das Clínicas & 1998 \\
\hline Processo Seletivo Misto & $\begin{array}{l}\text { Aperfeiçoar o Concurso Vestibular: introduzir o } \\
\text { Histórico Escolar Padronizado (HEP) no processo } \\
\text { de seleção }\end{array}$ & 1998 \\
\hline
\end{tabular}




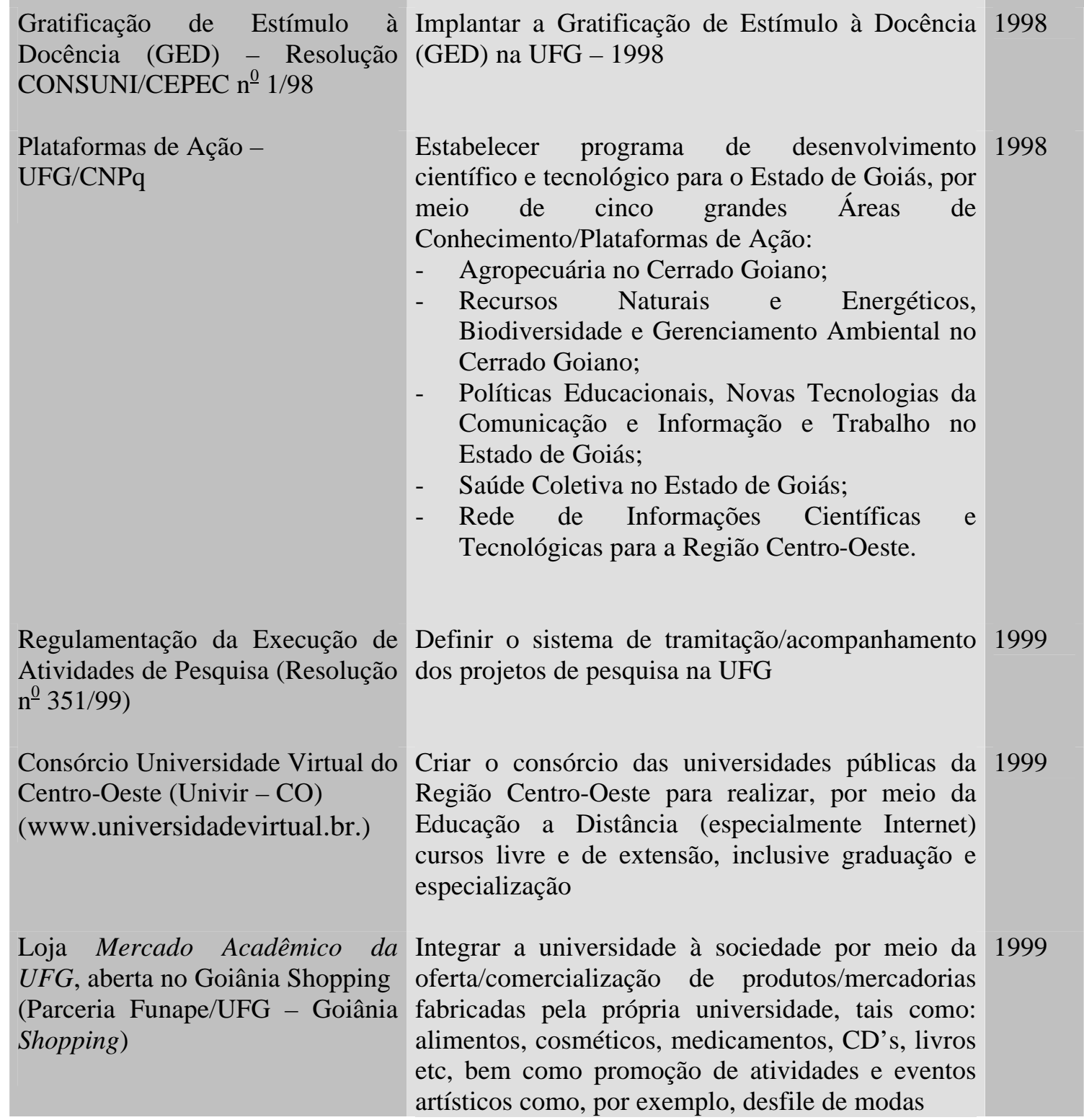




\begin{abstract}
Anexo 6
Universidade Federal de Goiás (UFG):

convênios assinados e/ou renovados período de janeiro de 1999 a dezembro de $1999^{223}$
\end{abstract}

\title{
Relação de Convênios
}

1. UFG/Empresa Brasileira de Pesquisa Agropecuária(EMBRAPA), visando cooperação técnica e financeira e concessão de estágio a estudantes

2. UFG/Escola Técnica Federal de Goiás (ETFG)/Prefeitura de Jataí-GO, visando colaboração mútua na execução do projeto de apoio e acompanhamento ao ensino fundamental e profissionalizante de jovem adulto trabalhador

3. UFG/Polícia Militar do Estado de Goiás/Fundação da Criança, do Adolescente e da Integração do Deficiente ( $F U N C A D)$, para execução de programas de interesse comum

4. Escola de Agronomia da UFG/Empresa Monsoy Ltda

5. UFG/Secretaria de Ciência e Tecnologia do Estado de Goiás

6. Escola de Agronomia da UFG/Fundação Projeto Pescar, visando a implantação de uma unidade de treinamento do Projeto Pescar

7. Escola de Veterinária da UFG/Universidade Federal do Paraná, visando oferecimento de estágio curricular

8. UFG/Instituto Nacional de Direito Público(INDP), para execução de programas de interesse comum

9. UFG/Fundação Jaime Câmara

10. UFG/Ministério das Relações Exteriores(ITAMARATY), por intermédio da Assessoria de Relações Federativas, para estabelecer cooperação técnica na execução de programas e projetos de interesse comum

11. Coordenadoria de Assuntos Internacionais da UFG/Auburn University (renovação de convênio)

12. UFG/Hospital de Urgências de Goiânia(HUGO), para estágio de alunos do curso de Medicina, ligados à Liga do Trauma

13. UFG/Organização das Voluntárias de Goiás $(O V G)$, visando o atendimento aos idosos do Abrigo Sagrada Família, bem como a concessão de estágio curricular a alunos do curso de Enfermagem

14. UFG/Serviço Nacional de Aprendizagem Industrial (SENAI-GO)/SINDUSCON-GO (Sindicato da Indústria da Construção no Estado de Goiás), visando a realização de cursos de pós-graduação lato sensu

15. UFG/Empresa Brasileira de Pesquisa Agropecuária(EMBRAPA), para fins de estabelecer parceria na área de recursos informacionais e tecnológicos

16. UFG/Secretaria Municipal de Saúde do Município de Goiânia, para os fins que especifica

17. UFG/High-Tech Tecnologia em Sistemas Térmicos Ltda, para a manutenção corretiva mensal dos sistemas de ar condicionado da Reitoria e do Departamento de Contabilidade da UFG

\footnotetext{
${ }^{223}$ Nas Atas dos Conselhos, nem sempre consta a finalidade do convênio. Face ao volume de convênios, em janeiro de 1999, foi criada Comissão Permanente para análise de propostas de convênio e contratos
} 
18. UFG/HC/FM/Centro de Referência em Tratamento e Pesquisa em Epilepsia/Serviço de Apoio às Micro e Pequenas Empresas de Goiás, visando estabelecer colaboração na execução de programas e projetos de interesse comum

19. UFG/FUNAPE/UCG, objetivando o desenvolvimento de cooperação técnico-científico

20. UFG/Sistema Municipal de Meio Ambiente (SEMMA) do Município de Goiânia, para concessão de estágio a estudantes

21. UFG/Universidad de Granada, para estabelecer intercâmbio de experiências e conhecimentos científicos

22. UFG/Fundação José Normanha, para apoio no desenvolvimento de atividades de Ensino e Pesquisa

23. UFG/Fundação de Apoio à Pesquisa (FUNAPE)/Município de Firminópolis/Município de São Luis de Montes Belos, visando a execução de programas de interesses recíprocos nas áreas de Ensino, Pesquisa, Extensão, Assessoria, Planejamento e Recursos Humanos

24. UFG/Câmara Municipal de Goiânia, para os fins de estabelecer cooperação na execução de programas e projetos de interesse recíproco

25. Faculdade de Comunicação e Biblioteconomia da UFG (FACOMB)/Câmara Municipal de Goiânia, para os fins de estabelecer cooperação na execução de programas e projetos de interesse recíproco

26. UFG/Fundação Cultural Palmares/Fundação Universidade de Brasília visando a realização do Projeto Quilombos, do Programa Universidade Solidária - Centro Oeste

27. Instituto de Informática da UFG (INF)Sociedade de Usuários de Informática e Telecomunicações de Goiás (SUCESU-GO), para os fins de estabelecer cooperação na execução de programas e projetos de interesse recíproco

28. UFG/Fundação Assistencial Educacional e Médico-Social(FAEMES), para estágio extracurricular e de extensão para alunos dos cursos de Graduação

29. UFG/Empresa de Assistência Técnica e Extensão Rural do Estado de Goiás (EMATER$G O$ ), para oportunizar a realização de estágios para os alunos dos cursos de Graduação

30. UFG/Fundação Educacional de Goiás, para os fins de estabelecer cooperação na execução de programas e projetos de interesse recíproco

31. Campus Avançado de Jataí da UFG(CAJ)/Município de Jataí, visando estabelecer cooperação para execução de serviços técnicos especializados

32. Escola de Agronomia da UFG(EA)Fundação Instituto Agronômico do Paraná (IAPAR), para a realização de estágios para os alunos dos cursos de Graduação

33. UFG/INCRA/FUNAPE, visando a educação e capacitação de jovens e adultos assentados em áreas de reforma agrária, no âmbito do PRONERA

34. UFG/Secretaria de Segurança Pública e Justiça/Diretoria Geral da Polícia Civil de Goiás, para execução de programas e projetos de interesse comum

35. UFG/UNESCO, com a finalidade de estabelecer cooperação técnica na execução de planos e projetos de interesse mútuo

36. UFG/Grupo Transas do Corpo, para execução de programas de interesse comum

37. UFG/Secretaria Nacional de Segurança Pública (SSP) - Departamento de Polícia Rodoviária Federal

38. UFG/Centro Federal de Educação Tecnológica de Goiás / Fundação Educacional de Jataí, para execução de projetos de ensino, pesquisa e extensão

39. UFG/PRPPG/Faculdade de Filosofia Cora Coralina/FUNAPE, para estabelecer a cooperação técnica na execução de cursos de Pós-Graduação lato sensu (e Termo Aditivo) 
40. CEPAE/UFG/Polícia Militar de Goiás, para execução de projeto de interesse comum

41. Faculdade de Nutrição (FANUT)-UFG/Empresa Transbrasiliana Transporte e Turismo Ltda., visando oferecer estágio supervisionado para alunos do Curso de Nutrição

42. UFG/Município de Vianópolis, visando oferecer estágios extra curriculares para alunos dos cursos de Agronomia e Veterinária, além de assistência técnica aos produtores do Município

43. Campus Avançado de Jataí (CAJ)-UFG/Empresa Comércio e Indústrias Brasileira Conimbra S.A., visando oferecer estágio supervisionado para alunos do CAJ-GO

44. UFG/IBAMA, visando estabelecer um regime de integração para a implementação de programas de Gestão Ambiental nas Unidades de Conservação Federais do Estado de Goiás

45. UFG/Fundação Rádio e Televisão Educativa e Cultural(RTVE), para realização do Curso de Especialização em Políticas Públicas

46. Campus Avançado de Jatai (CAJ)-UFG/Instituto Nacional de Metereologia, visando estabelecer cooperação técnica para operação e manutenção de uma estação climatológica principal, localizada no CAJ-GO

47. Escola de Engenharia (EEC)-UFG/Associação Brasileira de Cimento Portland, para fins de estabelecer cooperação na execução de progrmas e projetos de interesse recíproco

48. UFG/SINDUSCON-GO/SENAI, para realização do Curso de Pós-Graduação Gestão e Gerenciamento de Obra (Termo Aditivo)

49. Biblioteca Central (BC)-UFG/Hospital Dr. Anuar Auad/Hospital de Doênças Tropicais $(H D T)$, para fins de estabelecer parceria na área de recursos informacionais e tecnológicos

50. UFG/Rádio França Internacional, visando a retransmissão de programas de rádio

51. UFG/Nestlé do Brasil Ltda., para fins de estabelecer cooperação na execução de programas e projetos de interesse recíproco

52. UFG/FUNAPE/Sociedade Objetivo de Ensino Superior, para execução de programas de interesse comum

53. UFG/Fundação Universidade de Brasília (UnB), visando a execução de programa e projetos de interesse comum, na área de Medicina Tropical

54. UFG/Empresa de Transporte Urbano/GO (TRANSURB)

55. UFG/Prefeitura Municipal de Goiás 


\section{Anexo 7}

Universidade Federal de Goiás (UFG): cursos de graduação ${ }^{224}$, números e anos da Resolução CCEP/CEPEC, por unidades de ensino e por áreas de conhecimento

\begin{tabular}{|c|c|c|c|}
\hline $\begin{array}{c}\text { Áreas de } \\
\text { Conhecimento }\end{array}$ & Unidade & Curso & $\begin{array}{l}\text { Resoluções dos } \\
\text { Cursos }\end{array}$ \\
\hline Ciências Agrárias & $\begin{array}{l}\text { Escola de Agronomia } \\
\text { Escola de Veterinária }\end{array}$ & $\begin{array}{l}\text { Agronomia } \\
\text { Medicina Veterinária }\end{array}$ & $\begin{array}{l}\text { 350/92 - CCEP } \\
\text { 369/93 - CCEP }\end{array}$ \\
\hline Ciências Biológicas & $\begin{array}{l}\text { Instituto de Ciências } \\
\text { Biológicas }\end{array}$ & $\begin{array}{l}\text { Ciências Biológicas } \\
\text { (Licenciatura, } \\
\text { Modalidade Médica e } \\
\text { Biologia) }\end{array}$ & 265/87 - CCEP \\
\hline Ciências da Saúde & $\begin{array}{l}\text { Faculdade de Educ. Física } \\
\text { Faculdade de Enfermagem } \\
\text { Faculdade de Farmácia } \\
\text { Faculdade de Medicina } \\
\text { Faculdade de Nutrição } \\
\text { Faculdade de Odontologia }\end{array}$ & $\begin{array}{l}\text { Educação Física } \\
\text { Enfermagem } \\
\text { Farmácia (Modalidade } \\
\text { Alimentos, Análises } \\
\text { Clínicas, Farmacêutico } \\
\text { Industrial) } \\
\text { Medicina } \\
\text { Nutrição } \\
\text { Odontologia }\end{array}$ & $\begin{array}{l}\text { 393/95 - CCEP } \\
\text { 396/95 - CCEP e } \\
\text { 421/98 - CEPEC } \\
\text { 209/84 - CCEP }\end{array}$ \\
\hline $\begin{array}{l}\text { Ciências Exatas e } \\
\text { da Terra }\end{array}$ & $\begin{array}{l}\text { Instituto de Física } \\
\text { Instituto de Informática } \\
\text { Instituto de Matemática e } \\
\text { Estatística } \\
\text { Instituto de Química }\end{array}$ & $\begin{array}{l}\text { Física (bac. e lic.) } \\
\text { Ciência da Computação } \\
\text { Matemática(bac. e lic.) } \\
\text { Química (bac. e lic.) }\end{array}$ & $\begin{array}{l}\text { 335/92 - CCEP } \\
\text { 315/91 - CEPEC } \\
\text { 332/92 - CCEP } \\
\\
\text { 334/92 - CCEP }\end{array}$ \\
\hline Ciências Humanas & $\begin{array}{l}\text { Faculdade de Educação } \\
\text { Instituto de Estudos Sócio- } \\
\text { Ambientais }\end{array}$ & $\begin{array}{l}\text { Filosofia (bac. e lic.) } \\
\text { Ciências Sociais (bac. e } \\
\text { lic.) } \\
\text { História (bac. e lic.) } \\
\text { Pedagogia } \\
\text { Geografia (bac. e lic.) }\end{array}$ & $\begin{array}{l}\text { 372/93 e 388/95 } \\
\text { - CCEP } \\
\text { 287/89 - CCEP } \\
\text { 395/95 - CCEP } \\
\text { 394/95 - CCEP } \\
\text { 326/92 - CCEP e } \\
\text { 385/95 - CCEP }\end{array}$ \\
\hline $\begin{array}{l}\text { Ciências Sociais } \\
\text { Aplicada }\end{array}$ & $\begin{array}{l}\text { Faculdade de Comunicação } \\
\text { e Biblioteconomia }\end{array}$ & $\begin{array}{l}\text { Comunicação Social: } \\
\text { Jornalismo } \\
\text { Relações Públicas } \\
\text { Radialismo }\end{array}$ & $\begin{array}{l}\text { 196/84 - CCEP e } \\
\text { 426/98 - CEPEC } \\
\text { 196/84 - CCEP } \\
\text { 196/84 - CCEP }\end{array}$ \\
\hline
\end{tabular}

${ }^{224}$ Foram consideradas somente as unidades acadêmicas dos campi de Goiânia que oferecem cursos de graduação. 


\begin{tabular}{|c|c|c|c|}
\hline & Faculdade de Direito & $\begin{array}{l}\text { Publicidade e Propag. } \\
\text { Biblioteconomia } \\
\text { Direito }\end{array}$ & $\begin{array}{l}\text { 403/96 - CCEP } \\
\text { 195/84 - CCEP } \\
\text { 409/97 - CCЕР } \\
\text { 416/97 - CЕРEC } \\
\text { 425/98 - CЕPEC }\end{array}$ \\
\hline $\begin{array}{l}\text { Linguiística, Letras } \\
\text { e Artes }\end{array}$ & $\begin{array}{l}\text { Escola de Música } \\
\text { Faculdade de Artes Visuais }\end{array}$ & $\begin{array}{l}\text { Educ. Artística (Hab. } \\
\text { Música) } \\
\text { Música (bacharelado) } \\
\text { Educ. Artística (lic.) } \\
\text { Artes Visuais (Artes } \\
\text { Plásticas, Design } \\
\text { Gráfico, Design de } \\
\text { Interiores) } \\
\text { Design de Moda } \\
\text { Letras (bac. e lic.) }\end{array}$ & 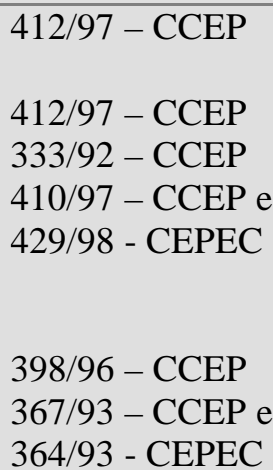 \\
\hline Engenharias & $\begin{array}{l}\text { Escola de Engenharia Civil } \\
\text { Escola de Engenharia } \\
\text { Elétrica }\end{array}$ & $\begin{array}{l}\text { Engenharia Civil } \\
\text { Engenharia Elétrica } \\
\text { Eng. da Computação }\end{array}$ & $\begin{array}{l}\text { 359/93 - CCEP } \\
\text { 397/96 - CCEP } \\
\text { 424/98 - CEPEC }\end{array}$ \\
\hline
\end{tabular}

Fonte: UFG. Catálogo dos Cursos de Graduação - 1997. 


\section{Anexo 8}

Universidade Federal de Goiás (UFG): princípios e critérios norteadores na elaboração dos currículos plenos dos cursos de graduação, conforme reformas curriculares - décadas de 80 e 90

\begin{tabular}{|c|c|c|}
\hline $\begin{array}{l}\text { Res. } n^{0} 184 / 1983 \text { e } \\
\text { Res. } n^{0} 194 / 1984\end{array}$ & Res. n 294/1989 & $\begin{array}{l}\text { Regulamento Geral dos } \\
\text { Cursos de Graduação } \\
\text { (RGCG) - } 1999\end{array}$ \\
\hline $\begin{array}{l}\text { Integração do ensino e da pesquisa } \\
\text { à realidade social }\end{array}$ & $\begin{array}{l}\text { Indissociabilidade do ensino e } \\
\text { da pesquisa à realidade social }\end{array}$ & \\
\hline Definição do perfil profissional & $\begin{array}{l}\text { Definição do projeto de } \\
\text { formação }\end{array}$ & Projetos de curso \\
\hline $\begin{array}{l}\text { Ênfase nas matérias que constituem } \\
\text { o núcleo epistemológico do curso }\end{array}$ & $\begin{array}{l}\text { Ênfase no elenco de matérias } \\
\text { que constituem o núcleo } \\
\text { epistemológico do curso }\end{array}$ & \\
\hline $\begin{array}{l}\text { Ensino e aprendizagem das } \\
\text { matérias: proposta curricular que } \\
\text { evidencie a estrutura fundamental } \\
\text { nas matérias (ementas justificadas) }\end{array}$ & $\begin{array}{l}\text { Ensino e aprendizagem } \\
\text { voltados para o núcleo } \\
\text { epistemológico (ementas } \\
\text { justificadas), buscando uma } \\
\text { articulação entre teoria e } \\
\text { prática }\end{array}$ & $\begin{array}{l}\text { O currículo deverá ser a } \\
\text { expressão do projeto } \\
\text { pedagógico de cada curso } \\
\text { abragendo o conjunto de } \\
\text { áreas do conhecimento, } \\
\text { disciplinas, atividades, } \\
\text { experiências e situações de } \\
\text { ensino-aprendizagem } \\
\text { relacionadas à formação do } \\
\text { aluno }\end{array}$ \\
\hline $\begin{array}{l}\text { Currículos Plenos dos Cursos }(\mathrm{CP}) \text { : } \\
\text { matérias do currículo mínimo, } \\
\text { matérias/atividades } \\
\text { complementares, estágio/internato }\end{array}$ & $\begin{array}{l}\text { Matérias do currículo mínimo, } \\
\text { matérias/atividades } \\
\text { complementares, } \\
\text { estágio/internato }\end{array}$ & 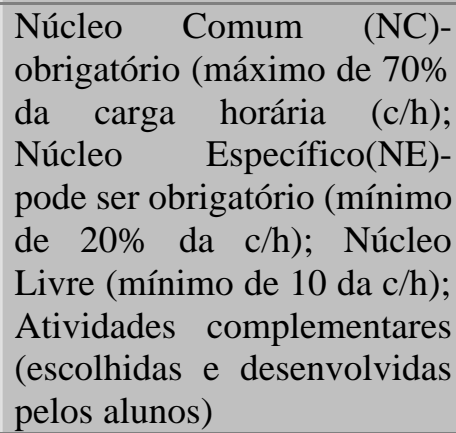 \\
\hline Estágio/internato & Estágio/internato & $\begin{array}{l}\text { Estágio curricular em } \\
\text { disciplinas do NC e do NE } \\
\text { Previsão de Coordenação de } \\
\text { Estágios da Pró-Reitoria de } \\
\text { Graduação }\end{array}$ \\
\hline $\begin{array}{l}\text { Regime seriado anual (Res. } \mathrm{n}^{0} \\
194 / 84 \text { ) }\end{array}$ & $\begin{array}{l}\text { Regime seriado anual (Res. } n^{0} \\
\text { 194/84) }\end{array}$ & $\begin{array}{l}\text { Semestres letivos regulares } \\
\text { (mínimo de } 100 \text { dias) }\end{array}$ \\
\hline
\end{tabular}


Matérias/disciplinas

Máximo de 30h semanais em

distribuídas em 32 ou 34 disciplinas do NC e do NE e

semanas letivas anuais $40 \mathrm{~h}$ nos cursos de período

Máximo de disciplina

por integral

série: 8

Hora/aula: 50 minutos de

Podem existir até 6 disciplinas efetiva atividade acadêmica

semestrais no curso

Matrícula por disciplina,

observados os respectivos

pré-requisitos

Atividades complementares Atividades complementares: nos CP: mínimo de 100 e mínimo de 100 horas

máximo de 200 horas

Previsão de habilitações, com Habilitações e/ou base em um tronco comum modalidades, de acordo com os projetos de curso

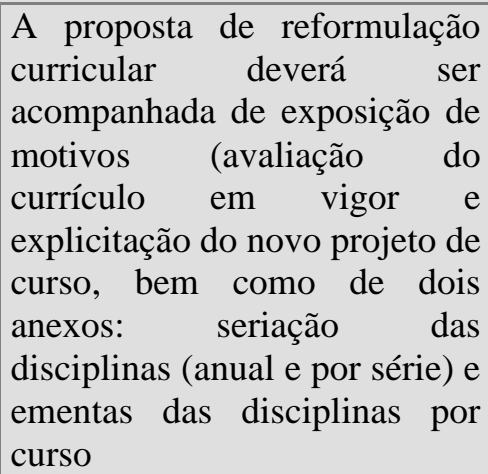

